\title{
DESENVOLVIMENTO DE COMPÓSITO A SER UTILIZADO COMO ALMOFADA DE APOIO NAS LIGAÇÕES ENTRE ELEMENTOS PRÉ-MOLDADOS
}

Dissertação apresentada à Escola de Engenharia de São Carlos, da Universidade de São Paulo, como parte dos requisitos para obtenção do título de Mestre em Engenharia de Estruturas.

ORIENTADOR: Prof ${ }^{\circ}$. Dr. Mounir Khalil El Debs

São Carlos

2004 
FOLHA DE JULGAMENTO

Candidato: Engenheiro LUCIANO CARLOS MONTEDOR

Dissertação defendida e julgada em 06-07-2004 perante a Comissão Julgadora:

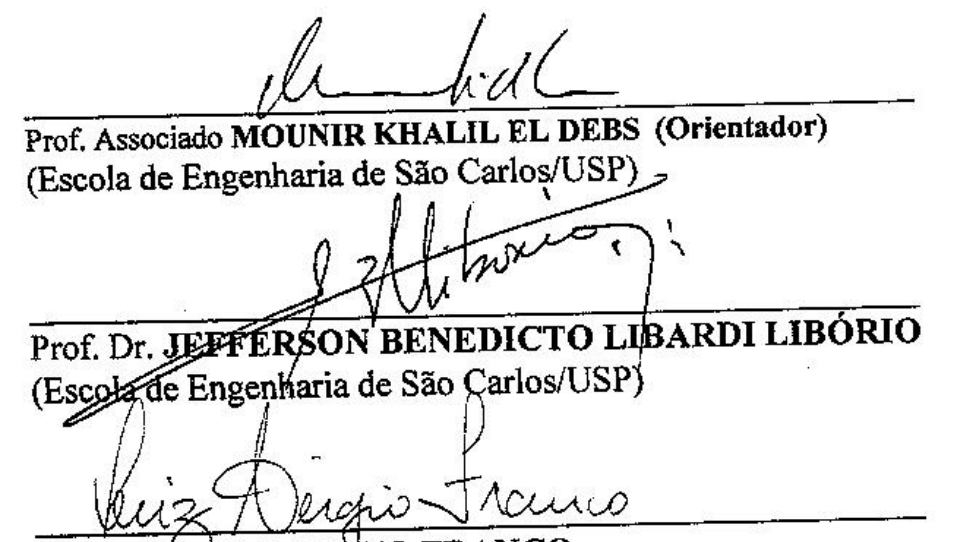

Aprovado

Prof, Associado MOUNIR KHALIL EL DEBS (Orientador)

(Escola de Engenharia de São Carlos/USP)

Prof. Dr. LLUIZ SERGIO FRANCO

(Escola Politécnica/USP)
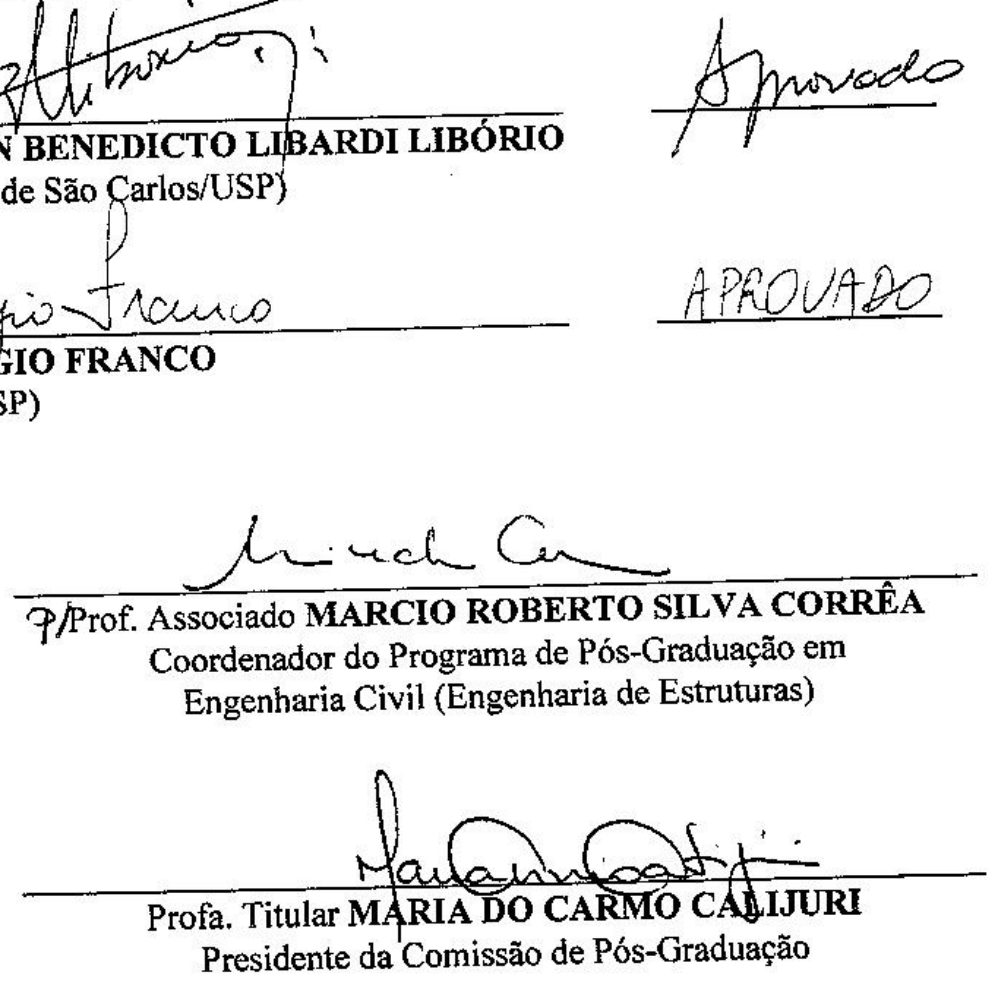
“... o homem, quando jovem, é só, apesar de suas múltiplas experiências. Ele pretende, nessa época, conformar a realidade com suas mãos, servindo-se dela, pois acredita que, ganhando o mundo, conseguirá ganhar-se a si próprio. Acontece, entretanto, que nascemos para o encontro com o outro, e não o seu domínio..."

(Hélio Pellegrino) 
A Deus, luz e proteção em mais esta etapa da minha vida. Aos meus pais, Francisco e Maria, pela coragem, dedicação e amor. À minha namorada, Mirela, pelo carinho, amor, compreensão e incentivo durante a realização deste trabalho. 


\section{AGRADECIMENTOS}

A Deus, Pai Eterno, pela misericórdia, amor, conhecimento, força espiritual e motivação concedidos em cada estágio da minha vida.

Aos meus pais, pelo apoio financeiro, pelas preces e, especialmente, pelo amor incondicional a cada momento.

Às minhas irmãs, Andréia e Ana Paula, sempre presentes e companheiras.

À minha amada namorada, Mirela, e seus familiares, que tanto me ajudaram com palavras, gestos, atitudes, orações e até mesmo com o silêncio.

Ao meu orientador, Mounir Khalil El Debs, por suas idéias, paciência, dedicação e amizade.

Aos grandes amigos encontrados na cidade de São Carlos: companheiros de república e do Departamento de Estruturas.

Em especial, aos amigos Rodrigo e Letícia, que tanto me ajudaram na realização das moldagens e ensaios necessários à efetuação deste trabalho.

Aos funcionários do Laboratório de Estruturas, pela presteza nos serviços.

Aos funcionários da secretaria do SET, Rosi, Marta, Nadir e Toninho, pela competência e bom atendimento.

À Coordenadoria de Aperfeiçoamento de Pessoal de Ensino Superior, CAPES, pelo apoio financeiro.

Agradeço, enfim, a todas as pessoas que acreditaram no meu potencial e que, de forma direta ou indireta, contribuíram para que este trabalho se concretizasse. 


\section{SUMÁRIO}

Lista de Figuras

Lista de Tabelas vi vi vi var

Resumo viii

Abstract $\quad$ ix

$\begin{array}{ll}\text { Capítulo } 1 \text { - Introdução } & 01\end{array}$

$\begin{array}{ll}\text { 1.1. Preliminares } & 01\end{array}$

1.2. Objetivos 06

1.3. Justificativas 06

1.4. Metodologia 07

1.5. Apresentação do trabalho 08

Capítulo 2 - Materiais utilizados nas almofadas 10

2.1.Preliminares 10

2.2.Cimento Portland 10

2.3.Vermiculita termo-expandida 12

2.4.Utilização de polímeros em argamassas e concretos 14

2.4.1. Polímeros 14

2.4.2. Látex estireno-butadieno (SB) 14

2.4.3. Argamassas modificadas com látex 15

2.5.Fibras 19

2.5.1. Fibra de PVA 22

2.5.2. Fibra de polipropileno 22

2.5.3. Fibra de vidro 23

Capítulo 3 - Caracterização dos materiais e ensaios realizados 25

3.1.Preliminares 25

3.2.Materiais 25

3.2.1. Cimento Portland 25

3.2.2. Areia 26

3.2.3. Vermiculita termo-expandida 27

3.2.4. Látex Estireno-Butadieno (SB) 28 
3.2.5. Aditivo Superplastificante

3.2.6. Fibras

3.2.7. Madeira

3.3.Programa experimental 31

3.3.1. Dosagem e características do compósito 31

3.3.2. Variáveis $\quad 34$

3.4.Características do material 35

3.4.1. Preparação dos corpos-de-prova cilíndricos 36

3.4.2. Resistência à compressão 38

3.4.3. Resistência à tração por compressão diametral 40

3.4.4. Módulo de elasticidade $\quad 42$

3.4.5. Depuração estatística dos resultados 45

3.5.Ensaios de placas $\quad 45$

3.5.1. Moldagem de placas 45

3.5.2. Ensaio de carga uniforme 47

3.5.3. Ensaio de carga localizada 53

3.6.Ligações de blocos 56

Capítulo 4-Resultados e análises

4.1.Características do material 63

4.1.1. Resistência à compressão 63

4.1.2. Resistência à tração por compressão diametral

4.1.3. Módulo de elasticidade 83

4.1.4. Análise das características do material 89

4.2.Ensaios de placas 98

4.2.1. Ensaio de carga uniforme 98

4.2.2. Ensaio de carga localizada 108

4.2.3. Análise dos ensaios em almofadas 117

4.3.Ensaios de ligações de blocos $\quad 125$

4.4.Análise de custo 134

Capítulo 5- Considerações finais e conclusões

Referências Bibliográficas 


\section{LISTA DE FIGURAS}

Figura 1.1 - Esquema de ensaio dos modelos 1.2 e 1.3 (MIOTTO, 2002) 04

Figura 1.2 - Fissuração do modelo 1.2 (sem almofada de apoio) 05

Figura 1.3 - Fissuração do modelo 1.3 (com almofada de apoio) 05

Figura 2.1 - Vermiculita: natural, expandida e partícula expandida 13

Figura 2.2 - Modelo idealizado de formação do concreto de cimento polímero 17

Figura 2.3 - Modelo idealizado do processo de formação do filme de polímero na partícula de cimento hidratado $\quad 18$

Figura 3.1 - Curva granulométrica da areia utilizada 27

Figura 3.2 - Curva granulométrica do agregado miúdo - vermiculita 28

Figura 3.3a - Moldagem com colher de pedreiro logo após colocação de água 36

Figura 3.3b - Moldagem utilizando máquina para facilitar a mistura 36

Figura 3.3c - Aplicação de fibra à mistura, após colocação de cimento, areia, vermiculita, látex e água, nesta seqüência 37

Figura 3.4a - Corpo-de-prova após capeamento para ser ensaiado 39

Figura 3.4b - Esquema de ensaio de compressão axial 39

Figura 3.5 - Dispositivo metálico para a realização dos ensaios de tração por compressão diametral 40

Figura 3.6a - Ensaio de tração por compressão diametral (a) 41

Figura 3.6b - Ensaio de tração por compressão diametral (b) 41

Figura 3.7 - Corpo-de-prova após capeamento para ser ensaiado 42

Figura 3.8a - Ensaio para obtenção do módulo de elasticidade (a) 43

Figura 3.8b - Ensaio para obtenção do módulo de elasticidade (b) 43

Figura 3.9 - Gráfico para determinação do módulo de elasticidade 43

Figura 3.10a - Ensaio para obtenção do módulo de elasticidade em corpos-de-prova por meio de transdutores e extensômetro (a) 44

Figura 3.10b - Ensaio para obtenção do módulo de elasticidade em corpos-de-prova por meio de transdutores e extensômetro (b) 44

Figura 3.11 - Moldagem com colher de pedreiro logo após colocação de água 46

Figura 3.12 - Moldagem utilizando máquina para facilitar a mistura 46

Figura 3.13 - Aplicação de fibra de PVA à mistura, após colocação de cimento, areia, vermiculita, látex e água, respectivamente 
Figura 3.14 - Adensamento em mesa vibratória, após aplicação da fibra de PVA

Figura 3.15 - Acabamento com colher de pedreiro embebida em água após adensamento

Figura 3.16 - Placas em sua composição final, após adensamento

Figura 3.17 - Desmoldagem 1 dia após a moldagem

Figura 3.18 - Colocação das placas desmoldadas na câmara úmida para aguardar a cura de sete dias

Figura 3.19a - Máquina INSTRON (sistema para aplicação de carga) $\quad 50$

Figura 3.19b - Sistema de controle de velocidade e aplicação 51

Figura 3.19c - Aplicação de carga em placa de $15 \mathrm{~cm}$ x $15 \mathrm{~cm}$

Figura 3.20 - Gráfico tensão x deformação para a mistura V5L0F3

$$
(\mathrm{e}=5 \mathrm{~mm})-\text { amostra }
$$

Figura 3.21 - Gráfico tensão x deformação para a mistura V5L0F3 $(\mathrm{e}=5 \mathrm{~mm})-2^{\mathrm{a}}$ amostra

Figura 3.22 - Ensaio de carga localizada em placas $\quad 55$

Figura 3.23 - Dispositivo metálico utilizado para ensaio de carga localizada 55

Figura 3.24 - Esquema do ensaio com a presença de almofada 57

Figura 3.25 $-1^{\mathrm{a}}$ série de ensaios $\quad 58$

Figura 3.26 $-2^{\mathrm{a}}$ série de ensaios $\quad 59$

Figura 3.27 $-3^{\mathrm{a}}$ série de ensaios $\quad 59$

$\begin{array}{ll}\text { Figura 3.28 }-4^{\mathrm{a}} \text { série de ensaios } & 60\end{array}$

$\begin{array}{ll}\text { Figura 3.29 }-5^{\mathrm{a}} \text { série de ensaios } & 61\end{array}$

Figura 3.30 - Aplicação de carga na ELE em protótipos da série 2

$$
(\mathrm{i}=10 \% \text { e } \mathrm{a}=10 \mathrm{~mm})
$$

Figura 4.1 - Gráfico comparativo das tensões para ensaio de compressão axial 64

Figura 4.2 - Gráfico das tensões para ensaio de compressão axial (látex constante)

Figura 4.3 - Gráfico das tensões para ensaio de compressão axial (sem vermiculita) 66

Figura 4.4 - Influência da fibra de PVA (sem vermiculita e 30\% de látex) 67

Figura 4.5 - Ensaio de compressão axial variando fibra de PVA (5\% de vermiculita)

Figura 4.6 - Influência da fibra de PVA (5\% de vermiculita e 30\% de látex) 69 
Figura 4.7 - Comparação entre fibra de PVA e vidro (5\% de vermiculita) $\quad 70$

Figura 4.8 - Ensaio de compressão axial (25\% de vermiculita) 70

Figura 4.9 - Ensaio de compressão axial (sem látex) 71

Figura 4.10 - Ensaio de compressão axial (30\% de látex) 72

Figura 4.11 - Influência da vermiculita (30\% de látex e 3\% de fibra de PVA) 73

Figura 4.12 - Gráfico comparativo das tensões para ensaio de compressão diametral

Figura 4.13 - Gráfico das tensões para ensaio de compressão diametral (látex constante)

Figura 4.14 - Gráfico das tensões para ensaio de compressão diametral (variando o látex e sem vermiculita)

Figura 4.15 - Influência da fibra de PVA (sem vermiculita e 30\% de látex) 78

Figura 4.16 - Ensaio com 5\% de vermiculita e fibra de PVA 78

Figura 4.17 - Influência da fibra de PVA (5\% de vermiculita e 30\% de látex) 79

Figura 4.18 - Comparação entre fibra de PVA e vidro (5\% de vermiculita) $\quad 80$

Figura 4.19 - Ensaio de compressão diametral

( $25 \%$ de vermiculita e $30 \%$ de látex)

Figura 4.20 - Ensaio de compressão diametral (sem látex) 81

Figura 4.21 - Influência da vermiculita (30\% de látex e 3\% de fibra de PVA) 82

Figura 4.22 - Resultados dos 3 CPs e da média $\quad 84$

Figura 4.23 - Média dos 3 CPs e regressão para obtenção da elasticidade $\quad 84$

Figura 4.24 - Gráfico comparativo dos Módulos de Elasticidade 86

Figura 4.25 - Influência da vermiculita no valor da elasticidade tangente $\quad 86$

Figura 4.26 - Influência do látex (sem vermiculita) 87

Figura 4.27 - Elasticidade das fibras de PVA e vidro ( $5 \%$ de vermiculita e $30 \%$ de látex)

Figura 4.28 - Influência da vermiculita na elasticidade (30\% de látex e 3\% de PVA)

Figura 4.29 - Corpo-de-prova no traço VOLOF0 (argamassa simples) após ensaio

Figura 4.30 - Corpo-de-prova no traço V5L30F4 após ensaio

Figura 4.31 - Corpo-de-prova no traço V5L30F2 após ensaio de tração por compressão diametral 
Figura 4.32 - Corpo-de-prova no traço V5L30F4 após ensaio de tração por compressão diametral

Figura 4.33 - Corpo-de-prova no traço V0L0F0 (argamassa simples) após ensaio de tração por compressão diametral

Figura 4.34 - Gráfico representativo de $\mathrm{f}_{\mathrm{c}} / \mathrm{f}_{\mathrm{t}}$ para todos os traços

Figura 4.35 - Correlações entre Módulo de Elasticidade e

Resistência à Compressão

Figura 4.36 - Correlações entre Módulo de Elasticidade e Resistência à

Compressão para o compósito e o concreto com resistência entre 10 e $50 \mathrm{MPa}$

Figura 4.37 - Gráfico comparativo das rigidezes (placa de $15 \mathrm{~cm} \times 15 \mathrm{~cm} \times 0,5 \mathrm{~cm}$ )

Figura 4.38 - Gráfico comparativo das rigidezes (placa de $15 \mathrm{~cm} \times 15 \mathrm{~cm} \times 1 \mathrm{~cm}$ )

Figura 4.39 - Gráfico comparativo das rigidezes (placa de $15 \mathrm{~cm} \times 15 \mathrm{~cm} \times 2 \mathrm{~cm}$ )

Figura 4.40 - Gráfico comparativo das rigidezes (almofadas de $15 \mathrm{~cm} \times 15 \mathrm{~cm}$ )

Figura 4.41 - Comparação entre placas de madeira e do compósito $(15 \mathrm{~cm} \times 15 \mathrm{~cm} \times 1 \mathrm{~cm})$

Figura 4.42 - Comparação entre placas de madeira e do compósito $(15 \mathrm{~cm} \times 15 \mathrm{~cm} \times 2 \mathrm{~cm})$

Figura 4.43 - Comparação entre placas de madeira, de neoprene e do compósito (placas de $10 \mathrm{~cm} \times 10 \mathrm{~cm}$ )

Figura 4.44 - Efeito de forma em placas do compósito

Figura 4.45 - Efeito de forma de placas do compósito, madeira e neoprene 107

Figura 4.46 - Gráfico de afundamento médio percentual para carga de ruptura 114

Figura 4.47 - Afundamento médio para carga de ruptura $(\mathrm{e}=10 \mathrm{~mm}) \quad 114$

Figura 4.48 -Afundamento da placa ( $2 \%$ de fibra de vidro)

Figura 4.49 -Afundamento da placa (5\% de vermiculita e variando fibra de PVA)

Figura 4.50 -Afundamento da placa (5\% de vermiculita e variando tipo de fibra)

Figura 4.51 - Almofada do compósito 
$\begin{array}{ll}\text { Figura 4.52 - Almofada de neoprene } & 117\end{array}$

$\begin{array}{ll}\text { Figura 4.53 - Almofada de madeira (Pinus Taeda) } & 117\end{array}$

Figura 4.54 - Estampagem de placa do compósito (V50L30VD2) 118

Figura 4.55 - Aplicação de carga em linha para avaliação do afundamento 119

Figura 4.56 - Afundamento de placa de 20mm em duas linhas 119

Figura 4.57 - Afundamento de placa de 10mm em duas linhas 119

Figura $4.58-E_{\mathrm{ct}} / \mathrm{R}$ para as placas de $15 \mathrm{~cm} \times 15 \mathrm{~cm} \quad 120$

$\begin{array}{ll}\text { Figura } 4.59-\mathrm{E}_{\mathrm{ct}} / \mathrm{R} \text { para as placas de } 10 \mathrm{~cm} \times 10 \mathrm{~cm} & 121\end{array}$

Figura $4.60-f_{c} / R$ para as placas de $15 \mathrm{~cm} \times 15 \mathrm{~cm} \quad 122$

Figura $4.61-\mathrm{f}_{\mathrm{c}} / \mathrm{R}$ para as placas de $10 \mathrm{~cm} \times 10 \mathrm{~cm} \quad 123$

Figura 4.62 - Relação entre as tensões (i = 0\% e e = 10mm) - Série $1 \quad 128$

Figura 4.63 - Relação entre as tensões (i = 10\% e e $=10 \mathrm{~mm})$ - Série $2 \quad 128$

Figura 4.64 - Relação entre as tensões ( $\mathrm{i}=10 \%$ e e $=20 \mathrm{~mm})$ - Série $3 \quad 129$

Figura 4.65 - Relação entre as tensões ( $i=0 \%$ e e $=20 \mathrm{~mm})$ - Série $4 \quad 130$

Figura 4.66 - Relação entre as tensões (i $=5 \%$ e e $=10 \mathrm{~mm})$ - Série $5 \quad 130$

Figura 4.67 -Carga máxima aplicada $(\mathrm{i}=0 \%$ e e $=10 \mathrm{~mm})$ - V5L30F3 131

Figura 4.68 -Carga máxima aplicada $(\mathrm{i}=10 \%$ e e $=10 \mathrm{~mm})$ - V5L30F3 132

Figura 4.69 -Carga máxima aplicada $(i=10 \%$ e e $=10 \mathrm{~mm})$ - V25L30VD2 132

Figura 4.70 -Carga máxima aplicada $(\mathrm{i}=5 \%$ e e $=10 \mathrm{~mm})-$ V5L30F3 133

Figura 4.71-Carga máxima aplicada $(i=5 \%$ e e $=10 \mathrm{~mm})-$ V25L30VD2 133 


\section{LISTA DE TABELAS}

Tabela 1.1 - Exemplo de ligação viga-pilar estudada por MIOTTO (2002) 03

Tabela 1.2 - Traço utilizado para as almofadas de apoio do modelo $1.3 \quad 04$

Tabela 2.1 - Composição do cimento de alta resistência inicial 12

Tabela 3.1 - Características do cimento utilizado 26

Tabela 3.2 - Propriedades do Látex Estireno-Butadieno 28

Tabela 3.3 - Propriedades do aditivo superplastificante 29

Tabela 3.4 - Propriedades das madeiras 30

Tabela 3.5 - Traço de referência em massa 31

Tabela 3.6 - Dosagem dos materiais 34

Tabela 3.7 - Legenda e descrição dos traços 35

Tabela 3.8 - Misturas para ensaios de caracterização do material 38

Tabela 3.9 - Misturas para ensaios de compressão uniforme nas placas de $15 \mathrm{~cm} \times 15 \mathrm{~cm} \quad 48$

Tabela 3.10 - Misturas para ensaios de compressão uniforme nas placas de $10 \mathrm{~cm} \times 10 \mathrm{~cm}$

Tabela 3.11 - Misturas para ensaios de carga localizada nas placas de $15 \mathrm{~cm} \times 15 \mathrm{~cm}$

Tabela 3.12 - Traço em massa dos blocos de concreto 56

Tabela 3.13 - Traços das almofadas utilizadas nas ligações 56

$\begin{array}{ll}\text { Tabela 3.14 - Ensaios de ligações realizados (resumo) } & 61\end{array}$

Tabela 4.1 - Resultados dos CPs para o traço V5L30F3 - compressão 63

Tabela 4.2 - Resultados dos CPs para o traço V5L30F3 - tração 74

Tabela 4.3 - Resultados dos CPs para o traço V5L30VD2 - cálculo do módulo de elasticidade $\quad 83$

Tabela 4.4 - Relação entre resistência à compressão e à tração $\left(f_{c} / f_{t}\right)$

Tabela 4.5 - Relação $f_{c} / f_{t}$ variando quantidade de vermiculita 93

Tabela 4.6 - Correlação entre o módulo de elasticidade e a resistência à compressão $\quad 95$

Tabela 4.7 - Relação $\left[E /\left(f_{c}\right)^{1 / 2}\right]$ variando quantidade de vermiculita 96

Tabela 4.8 - Ensaios de rigidez em placas de $15 \mathrm{~cm}$ x $15 \mathrm{~cm} \quad 99$

Tabela 4.9 - Ensaios de rigidez em placas de $10 \mathrm{~cm}$ x $10 \mathrm{~cm}$ 
Tabela 4.10 - Carga de ruptura da placa $(\mathrm{kN})$

Tabela 4.11 - Medidas dos 4 pontos da placa antes e depois da aplicação da carga

Tabela 4.12 - Afundamento médio da almofada (mm)

Tabela 4.13 - Afundamento médio percentual da almofada (\%)

Tabela 4.14 - Afundamento das placas para o traço V5L30F2

Tabela 4.15 - Afundamento em placas de $15 \mathrm{~cm}$ x $15 \mathrm{~cm}$ - Valores absolutos

Tabela 4.16 - Afundamento percentual em placas de $15 \mathrm{~cm} \times 15 \mathrm{~cm}$

Tabela 4.17 - Força de ruptura e afundamento em placas de $15 \mathrm{~cm}$ x $15 \mathrm{~cm}$

Tabela 4.18 - Razão média entre o módulo de elasticidade e a rigidez (E/R)

Tabela $4.19-\mathrm{f}_{\mathrm{c}} / \mathrm{R}$ e $\mathrm{R} / \mathrm{f}_{\mathrm{c}}$ para almofadas de $15 \mathrm{~cm} \times 15 \mathrm{~cm}$ e de $10 \mathrm{~cm} \times 10 \mathrm{~cm}$

Tabela 4.20 - Tensão média em MPa para série 1 ( $i=0 \%$ e e $=10 \mathrm{~mm})$

Tabela 4.21 - Tensão média em MPa para série $2(\mathrm{i}=10 \%$ e e $=10 \mathrm{~mm})$

Tabela 4.22 - Tensão média em MPa para série $3(i=10 \%$ e e $=20 \mathrm{~mm})$

Tabela 4.23 - Tensão média em MPa para série 4 (i = 0\% e e = 20mm)

Tabela 4.24 - Tensão média em MPa para série $5(\mathrm{i}=5 \%$ e e $=10 \mathrm{~mm})$

Tabela 4.25 - Análise de custo das almofadas (em R\$) 


\section{RESUMO}

MONTEDOR, L.C. (2004). Desenvolvimento de compósito a ser utilizado como almofada de apoio nas ligações entre elementos pré-moldados. 144p. Dissertação (Mestrado) - Escola de Engenharia de São Carlos, Universidade de São Paulo, São Carlos, 2004.

Neste trabalho foi feito um estudo de uma argamassa especial, à base de cimento e acrescida de vermiculita, látex e fibras curtas (PVA e vidro), visando a sua utilização em ligações entre elementos de concreto pré-moldado. Realizaram-se ensaios de corpos-de-prova cilíndricos de $50 \mathrm{~mm}$ x $100 \mathrm{~mm}$ para a determinação das características do compósito, tais como: resistência à compressão, resistência à tração e módulo de elasticidade. Foram moldados 20 traços do compósito, variando as quantidades de cada um dos materiais. Foram realizados ensaios de compressão em placas de espessuras 5 , 10 e $20 \mathrm{~mm}$ para determinação da rigidez (relação entre a tensão e a deformação específica) e do afundamento pela aplicação de carga concentrada. Também foram realizados ensaios de ligações de blocos de concreto, com e sem almofada na emenda. Com base nos ensaios realizados, notourse que ao se utilizar maiores quantidades de vermiculita, a tendência era de diminuir as resistências à compressão e à tração e também o módulo de elasticidade; entretanto, com a adição de látex e, sobretudo, de uma quantidade considerável de fibra à mistura, sua resistência praticamente se igualava à resistência do corpo sem vermiculita com a vantagem de evitar fissuras ou lascamento, tornando-se adequado para ser utilizado como elemento de apoio em ligações de concreto pré-moldado. Notou-se um acréscimo de resistência à compressão superior a $30 \%$ ao se utilizar almofada na emenda nos casos em que não há excentricidade nas ligações entre blocos de concreto.

Palavras-chave: almofada; argamassa especial; concreto pré-moldado; ligações; placas; rigidez. 


\section{ABSTRACT}

MONTEDOR, L.C. (2004). Composite development to be used as support cushion in the connections between precast elements. 144p. M.Sc. Dissertation - Escola de Engenharia de São Carlos, Universidade de São Paulo, São Carlos, 2004.

This research deals with a special mortar made with cement, which it was added vermiculite, latex and short fibers (PVA and glass) to be used in connections between elements of precast concrete. It was made cylindrical samples of $50 \mathrm{~mm} \mathrm{x}$ $100 \mathrm{~mm}$ for the determination of the characteristics of the composite, such as: compression strength, tensile strength and modulus of elasticity. It was made 20 mixtures of the composite, varying the amounts of each one of the materials. Compression tests were made in plates with thickness of 5,10 e $20 \mathrm{~mm}$ for determination of the stiffness (relationship between stress and specific deformation) and deformation due the application of concentrated load. Connections tests on concrete blocks were also made, with cushion and without it in the connection. Based in these tests, it was noticed that when using larger amounts of vermiculite, the tendency was of reducing the compression strength and tensile strength and the modulus of elasticity too; however, with the addition of latex and, above all, of a considerable amount of fiber to the mixture, your strength practically was equaled to the strength of the material without vermiculite with the advantage of avoiding cracks or split, becoming adequate to be used as cushion in precast concrete connections. It was noticed an increment of larger compression strength than $30 \%$ when using cushion in the connection in the cases in that there is not eccentricity in the connections between concrete blocks.

Keywords: connections; cushion; plates; precast concrete; special mortar; stiffness. 


\section{INTRODUÇÃ̃O}

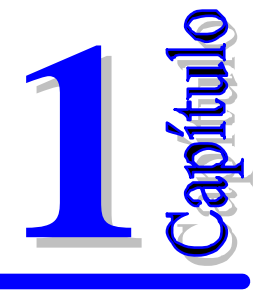

\subsection{Preliminares}

Esta dissertação enquadra-se na linha de pesquisa sobre o estudo de "Ligações entre elementos pré-moldados", que vem sendo desenvolvida no Departamento de Engenharia de Estruturas da Escola de Engenharia de São Carlos (EESC-USP) há algum tempo.

Em geral, as estruturas de concreto pré-moldado são caracterizadas por apresentar facilidade de execução de seus elementos. Entretanto, a necessidade de ligações entre os elementos corresponde a um dos principais problemas a serem enfrentados no emprego desse sistema estrutural (EL DEBS, 2000).

As ligações possuem importância fundamental tanto para a produção como para o comportamento da estrutura montada. Sendo assim, é necessário que se tomem os cuidados necessários no estabelecimento destas, a fim de que sejam efetuadas de maneira adequada.

Segundo CEB (1991), para o projeto das ligações, é necessário que se leve em conta alguns princípios gerais, como listado a seguir:

a) As ligações devem assegurar a rigidez e a estabilidade global da estrutura;

b) Devem ser levadas em conta as tolerâncias de fabricação e montagem;

c) Análise das ligações deve se estender às extremidades dos elementos que elas concorrem;

d) Deve-se prever acomodações da ligação, até que esta atinja sua capacidade. 
Além disso, destaca-se que o conhecimento do comportamento de um sistema estrutural de concreto pré-moldado está diretamente relacionado ao comportamento de suas ligações, já que estas são responsáveis, entre outros aspectos, pela distribuição dos esforços da estrutura.

Um dos aspectos mais importantes das estruturas de concreto pré-moldado diz respeito à facilidade da produção de seus componentes. Todavia, as ligações entre tais elementos, que constituem a porção mais importante no projeto de estruturas prémoldadas, correspondem a um problema significativo no comportamento global da estrutura (MIOTTO, 2002).

As ligações devem se adequar a critérios relativos a resistência, ductilidade, durabilidade e resistência ao fogo, bem como apresentar aspectos como estética, produção e montagem (EL DEBS, 2000).

Nas ligações entre vigas e pilares utiliza-se atualmente no país o cloropreno, conhecido comercialmente como neoprene. Almofadas deste elastômero, juntamente com chumbador, têm sido bastante utilizadas em ligações viga-pilar, sendo que sua aplicação se dá em estruturas de galpões de uso múltiplo e edificações de mais de um pavimento com pequena altura.

Trata-se de um elastômero e, como tal, sua função é promover uma distribuição uniforme das tensões de contato entre os elementos, bem como tornar possíveis deslocamentos horizontais e rotações no suporte. O vazio entre a viga e o chumbador é geralmente preenchido com graute, restringindo o deslocamento horizontal. De qualquer modo, não ocorrendo restrições de movimento, a flexibilidade do pilar ainda permite, em muitos casos, uma redução significativa das tensões (MIOTTO, 2002).

No caso deste trabalho, tem-se por objetivo estudar o desenvolvimento de uma peça feita de argamassa, utilizada como apoio, com material à base de cimento, que seja suficientemente flexível para distribuir as tensões de contato bem como possa permitir uma pequena rotação da viga no apoio. Este material deveria possuir, portanto, módulo de elasticidade e rigidez tão baixos quanto possível, um valor relativamente alto de resistência e ser capaz de permitir o máximo afundamento possível quando da aplicação da máxima carga pontual. 
Algumas aplicações (moldagens e ensaios preliminares) do referido compósito já haviam sido realizadas em trabalhos anteriores. MIOTTO (2002) observou estes resultados e utilizou almofadas deste material em determinados tipos de ligações para desenvolvimento de sua Tese de Doutorado. Na seqüência, são mostrados alguns dos resultados apresentados por esta pesquisadora.

MIOTTO (2002) notou que este tipo de ligação não apresentava diferença com relação à estética, produção e montagem se comparada à forma tradicional.

Todavia, apresenta melhor desempenho com relação à resistência se comparada ao cloropreno. Outro aspecto importante é que se trata de um material mais rígido que o cloropreno, o que significaria melhores condições com relação a ações laterais. Este procedimento permitiria aumentar a altura da estrutura sem alterar a seção da coluna ou, ainda, reduzir as dimensões das colunas e os custos de fundação, para uma mesma altura das construções.

Em alguns ensaios já realizados por MIOTTO (2002) com o material no Laboratório de Estruturas, verificou-se que o mesmo apresentou boa capacidade de deformação.

A pesquisadora estudou, entre outras coisas, a ligação viga-pilar mostrada na Tabela 1.1, na qual estão representados 2 modelos de estudo, sendo que a diferença entre eles diz respeito à presença ou não da almofada de apoio do referido compósito nas ligações. A almofada de apoio está presente entre o consolo e a viga no modelo 1.3 e em ambos modelos aplica-se momento nos sentidos negativo e positivo.

Tabela 1.1 - Exemplo de ligação viga-pilar estudada por MIOTTO (2002)

\begin{tabular}{|c|c|c|c|c|}
\hline \multirow[b]{2}{*}{ Modelo } & \multirow[b]{2}{*}{ Características dos modelos } & \multicolumn{3}{|c|}{ Variáveis } \\
\hline & & $\begin{array}{c}\ell_{\mathrm{c}} \\
(\mathrm{cm})\end{array}$ & $\begin{array}{c}\phi_{b} \\
(\mathrm{~mm})\end{array}$ & $\begin{array}{l}\text { almofada } \\
\text { de apoio }\end{array}$ \\
\hline modelo 1.2 & $\begin{array}{l}\text { chumbadores } \\
\text { (фvariável) }\end{array}$ & 25 & 25,4 & sem \\
\hline modelo 1.3 & lc & 25 & 25,4 & com \\
\hline
\end{tabular}


Na Figura 1.1, pode-se observar o esquema do ensaio realizado. O traço indicado para a confecção das almofadas utilizadas no modelo 1.3 consta na Tabela 1.2, sendo que a fibra utilizada foi a de polipropileno e não se utilizou vermiculita.

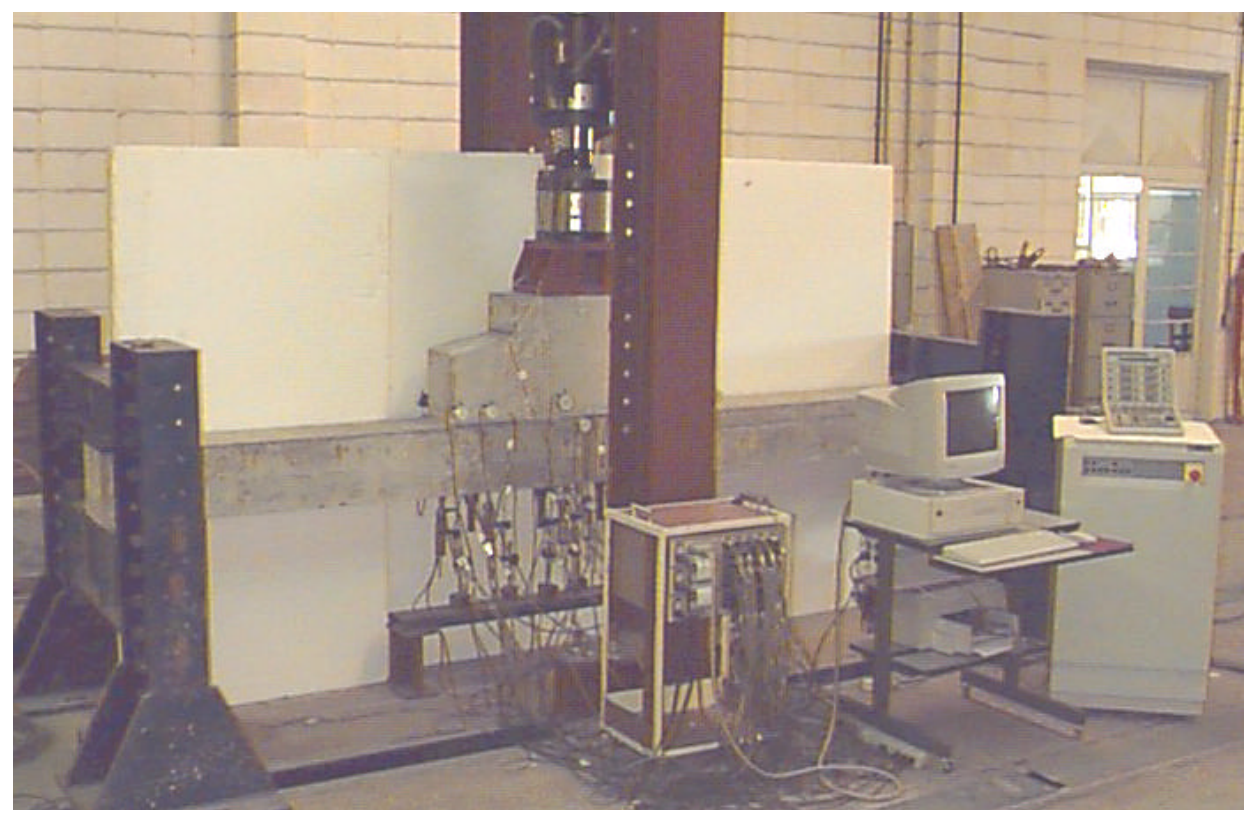

Figura 1.1 - Esquema de ensaio dos modelos 1.2 e 1.3 (MIOTTO, 2002)

Tabela 1.2 - Traço preliminar utilizado para as almofadas de apoio do modelo 1.3

\begin{tabular}{||c|c|c|c|c||}
\hline \hline Cimento & Areia & Látex & Fibra & Água \\
\hline 1 & 0,06 & 0,3 & $2 \%$ & 0,34 \\
\hline
\end{tabular}

Aplicou-se nos modelos um carregamento alternado, de curta duração e com controle de deslocamentos, através da utilização de um atuador servo-controlado com capacidade de $500 \mathrm{kN}$.

Nas Figuras 1.2 e 1.3, representa-se a configuração das fissuras dos modelos $1.2 \mathrm{e}$ 1.3 após realização de ensaio.

MIOTTO (2002) destacou que a primeira fissura apareceu nas vigas quando a força aplicada no ensaio atingiu em torno de $-30 \mathrm{kN}$ e $-40 \mathrm{kN}$ para os modelos 1.2 e 1.3, respectivamente. Acredita-se que essa diferença se deva à presença da almofada de apoio que pode ter retardado o aparecimento das fissuras no modelo 1.3, devido a sua capacidade de acomodação. Contudo, a força última aplicada nos modelos foi praticamente igual e a distinção encontra-se na fissuração. 


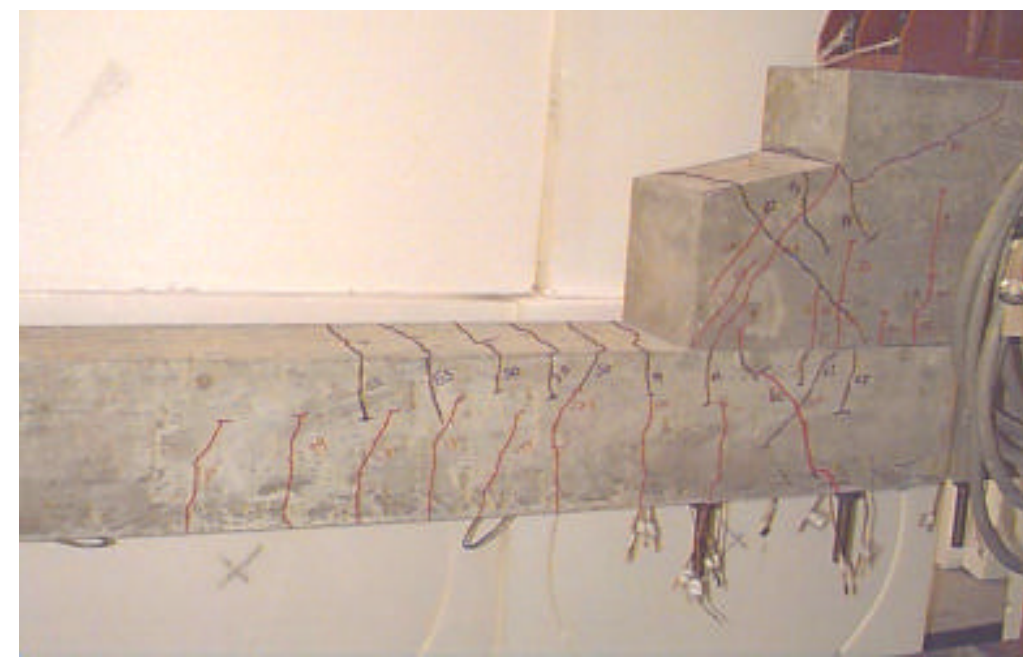

Figura 1.2 - Fissuração no modelo 1.2 (sem almofada de apoio) (MIOTTO, 2002)

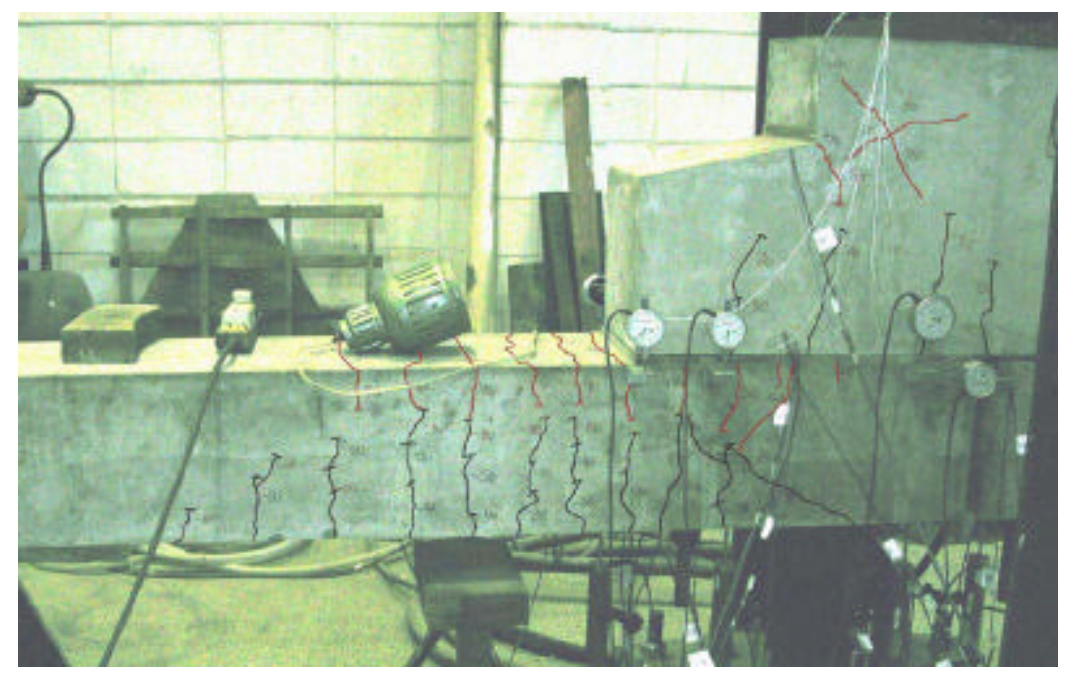

Figura 1.3 - Fissuração no modelo 1.3 (com almofada de apoio) (MIOTTO, 2002)

Na Figura 1.2, ao contrário da Figura 1.3, as fissuras marcadas em vermelho são devidas à ação do momento fletor negativo, enquanto que, as fissuras marcadas em preto são conseqüências da ação de momento fletor positivo na ligação. Conforme pode ser observado nas Figuras 1.2 e 1.3, a presença da almofada de apoio proporcionou uma menor fissuração na região de compressão do consolo do modelo 1.3.

No trabalho efetuado por MIOTTO (2002) foram realizados apenas alguns estudos preliminares do material utilizado na almofada. No trabalho desenvolvido nesta dissertação, procurou-se realizar um estudo mais aprofundado do referido compósito, variando as quantidades de cada um dos componentes da mistura e realizando diversos ensaios em corpos-de-prova e placas da argamassa especial em questão. 


\subsection{Objetivos}

O presente trabalho é elaborado com vistas ao estudo de uma argamassa especial à base de cimento empregada em ligações entre elementos pré-moldados.

Dessa forma, o objetivo da pesquisa foi o de desenvolver um compósito para ser utilizado como almofada de apoio em ligações entre elementos pré-moldados, por meio de estudo de características de cada traço do material como resistência, elasticidade, rigidez e afundamento.

O intuito é de se obter um material, na medida do possível, flexível, capaz de regularizar e distribuir as tensões nas regiões de ligações entre elementos pré-moldados. Este material deve possuir, portanto, módulo de elasticidade e rigidez tão baixos quanto possível, um valor relativamente alto de resistência e ser capaz de permitir o máximo afundamento possível quando da aplicação da máxima carga pontual.

O trabalho tem ainda por objetivo a aplicação do material em ligações de blocos de concreto para analisar o comportamento das almofadas em ligações e avaliar a possibilidade de sua utilização no mercado.

\subsection{Justificativas}

O estudo das ligações entre elementos pré-moldados é de extrema importância, visto que as mesmas constituem a porção mais relevante no projeto de estruturas prémoldadas.

Sendo assim, as justificativas para a realização do presente projeto são descritas na seqüência:

a) Existem poucos estudos neste sentido no país, dado que este material é novo e vem sendo estudado no Departamento de Engenharia de Estruturas da Escola de Engenharia de São Carlos;

b) $\mathrm{O}$ comportamento de tal argamassa, quando utilizada nas ligações entre elementos pré-moldados, é pouco conhecido, o que justifica a realização de novos ensaios e avaliação dos resultados para posterior aplicação em ligações de estruturas convencionais de concreto pré-moldado; 
c) A argamassa em questão já apresentou boa capacidade de deformação, em alguns testes previamente realizados, característica essa bastante importante para um material que deve ser utilizado em ligações de elementos prémoldados;

d) A adição de vermiculita, látex e fibras à argamassa de cimento tende a reduzir o módulo de elasticidade do material, sobretudo ao se comparar o referido material ao cloropreno (elastômero mais utilizado no país nos dias atuais), característica essa de grande importância para um material que deve ser utilizado como de apoio;

e) De acordo com resultados preliminares obtidos em pesquisas já realizadas com o referido material notoutse que o mesmo não apresentava diferença com relação à estética, produção e montagem se comparado à forma tradicional;

Com base nos aspectos citados nota-se a relevância em se estudar o material, apresentar referências bibliográficas relacionadas ao assunto em questão, bem como propor alternativas para a utilização do compósito.

\subsection{Metodologia}

No decorrer deste trabalho realizourse uma extensa pesquisa bibliográfica sobre argamassas de cimento, agregados como vermiculita, polímeros como o látex estirenobutadieno e fibras curtas como a de PVA, polipropileno e vidro, bem como a utilização dos anteriores acrescidos à argamassa de cimento.

Sendo assim, estabeleceram-se diversas dosagens com os referidos materiais e avaliaram-se as características do compósito. Para a escolha das misturas procurou-se estabelecer uma ordem na qual houvesse variação da quantidade de cada um dos elementos presentes, no intuito de se obter um material, na medida do possível, flexível, capaz de regularizar e distribuir as tensões nas regiões de ligações entre elementos prémoldados. Este material deveria possuir, portanto, módulo de elasticidade e rigidez tão baixos quanto possível, um valor relativamente alto de resistência e ser capaz de permitir o máximo afundamento possível quando da aplicação da máxima carga pontual. 
Sendo assim, realizaram-se ensaios de caracterização do material (resistência à compressão e à tração por compressão diametral e módulo de elasticidade) em corposde-prova cilíndricos de $5 \mathrm{~cm}$ x $10 \mathrm{~cm}$, variando as quantidades de cada elemento (cimento, de alta resistência inicial, areia, vermiculita, látex estireno-butadieno e fibras curtas, de PVA ou vidro), a fim de se obter o material de apoio desejado.

Realizados os ensaios de caracterização do material, foram escolhidos alguns traços cujas características foram tidas como as mais apropriadas para o material que se deseja e, com estes traços, foram moldadas almofadas de $10 \mathrm{~cm}$ x $10 \mathrm{~cm}$ e $15 \mathrm{~cm}$ x $15 \mathrm{~cm}$, variando a espessura em 5, 10 e $20 \mathrm{~mm}$. Nestas almofadas foram realizados ensaios de compressão uniforme e de força concentrada para verificar a rigidez de placa e a capacidade de acomodar imperfeições inerente à mesma.

Após a determinação das referidas características do material por meio de ensaios em corpos-de-prova cilíndricos, utilizaram-se alguns traços específicos em placas para a determinação das rigidezes das almofadas, a partir de ensaio de compressão das mesmas, e do afundamento, a partir da aplicação de carga pontual nas placas.

Verificadas essas características das almofadas, ensaiourse à compressão ligações de blocos de concreto com ou sem a presença de almofadas entre os blocos, para avaliar a influência de sua utilização nas ligações.

\subsection{Apresentação do trabalho}

No capítulo 1, introdução, o assunto do trabalho é apresentado e discutido; nele é exposta uma pequena revisão bibliográfica de estruturas, os objetivos e justificativas do trabalho, bem como a metodologia adotada para a realização do projeto.

O capítulo 2, materiais utilizados nas almofadas, apresenta uma revisão bibliográfica dos principais materiais que compõem as almofadas. Trata do reforço de argamassas de cimento Portland com introdução de fibras de PVA, polipropileno e vidro e acréscimo de vermiculita e látex estireno-butadieno, influenciando no peso, na resistência e na elasticidade das almofadas.

No capítulo 3, caracterização dos materiais e ensaios realizados, são apresentados o planejamento experimental, os materiais e os métodos utilizados na 
execução de cada tipo de ensaio (caracterização do material, ensaios de placas e ligações de blocos).

O capítulo 4, resultados e análises, apresenta os resultados obtidos por meio dos experimentos realizados e uma breve análise dos gráficos que expõem os resultados referentes às características do material, aos ensaios de placas e de ligações que utilizam o compósito.

No capítulo 5, considerações finais e conclusões, o material é avaliado e apresentam-se as vantagens e desvantagens de se utilizá-lo, no intuito de viabilizar a utilização prática do compósito em ligações entre elementos pré-moldados. 


\section{MATERIAIS UTILIZADOS NAS ALMOFADAS}

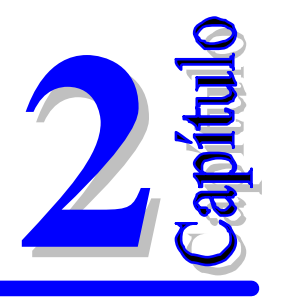

\subsection{Preliminares}

Este capítulo trata especificamente dos materiais utilizados para a confecção das almofadas do compósito. O compósito em estudo corresponde a uma argamassa de cimento Portland (CP V - ARI) que ainda recebe os seguintes ingredientes: vermiculita, látex estireno-butadieno e fibras, com o objetivo de se obter um compósito com boa resistência e baixo módulo de elasticidade para que possa desempenhar função similar a do elastômero em ligações de concreto pré-moldado, regularizando as tensões atuantes e diminuindo a fissuração dos elementos.

A seguir, são relatadas as principais características dos materiais a serem utilizados nas misturas que serão efetuadas no decorrer da pesquisa.

\subsection{Cimento Portland}

O cimento Portland é composto sobretudo de material calcário, como rocha calcária ou gesso, alumina e sílica, que podem ser encontrados em argilas e xisto. As argilas contêm também alumina $\left(\mathrm{Al}_{2} \mathrm{O}_{3}\right)$ e, freqüentemente, óxidos de ferro $\left(\mathrm{Fe}_{2} \mathrm{O}_{3}\right)$ e álcalis. A presença da alumina, dos óxidos de ferro e magnésio e dos álcalis na mistura de matérias-primas tem efeito mineralizante na formação de silicatos de cálcio. Quando não estão presentes quantidades suficientes de alumina e óxido de ferro nas matériasprimas principais, estes são propositalmente incorporados à mistura por adição de materiais secundários, como a bauxita e o minério de ferro (MEHTA \& MONTEIRO, 1994). Após a extração da matéria-prima, a moagem e a mistura desse material, realizam-se ajustes para a obtenção da composição química pretendida. Em seguida, a 
mistura é levada a um grande cilindro de material refratário, com até $8 \mathrm{~m}$ de diâmetro, com até 230 metros de comprimento, girando de forma lenta em torno do eixo que está ligeiramente inclinado em relação à horizontal. A mistura, no seu movimento forno abaixo, encontra temperaturas progressivamente mais elevadas, liberando água e $\mathrm{CO}_{2}$, de início; na seqüência, o material seco sofre uma série de reações químicas até que, finalmente, na parte mais quente do forno, cerca de $20 \%$ a $30 \%$ do material se funde e o calcário, a sílica e a alumina se recombinam. A massa se funde em pelotas, conhecidas como clínquer e são resfriadas. Após adição de gesso e dos minerais desejados, ocorre a moagem, que corresponde à outra fase de grande importância, pois, dependendo da finura em que os componentes são moídos, o cimento necessitará de mais ou menos água para obter a plasticidade desejada do concreto, maior ou menor será o calor de hidratação etc. (NEVILLE, 1997).

No Brasil, existem vários tipos de cimento Portland distintos entre si, com relação à sua composição e à finura dos grãos, todavia, serão abordados, neste instante, apenas aqueles mais comuns:
a) Cimento Portland comum;
b) Cimento Portland composto;
c) Cimento Portland de alto forno;
d) Cimento Portland pozolânico;
e) Cimento Portland de alta resistência inicial.

Em menor escala, são consumidos os seguintes tipos de cimento:

a) Cimento Portland resistente aos sulfatos;

b) Cimento Portland de alta resistência inicial resistente aos sulfatos.

O cimento utilizado neste projeto é o de alta resistência inicial (CP V ARI). O desenvolvimento desse tipo de cimento é conseguido pela utilização de uma dosagem diferente na produção do clínquer, bem como pela moagem mais fina do cimento, de forma que, ao reagir com a água, ele adquire elevadas resistências, com maior velocidade (KATTAR \& ALMEIDA, 1999).

Para se ter uma melhor idéia a respeito desse tipo de cimento, a Tabela 2.1 apresenta as composições do CP V ARI. 
Tabela 2.1 - Composição do cimento de alta resistência inicial (KATTAR \&

ALMEIDA, 1999)

\begin{tabular}{||c|c|c|c|c|c||}
\hline Tipo de CP & Sigla & $\begin{array}{c}\text { Clínquer }+ \\
\text { gesso (\%) }\end{array}$ & $\begin{array}{c}\text { Escória } \\
\text { granulada de } \\
\text { alto forno } \\
(\%)\end{array}$ & $\begin{array}{c}\text { Material } \\
\text { pozolânico } \\
(\%)\end{array}$ & $\begin{array}{c}\text { Material } \\
\text { Carbonático } \\
(\%)\end{array}$ \\
\hline $\begin{array}{c}\text { Alta } \\
\text { resistência } \\
\text { inicial }\end{array}$ & CP V ARI & $100-95$ & - & - & $0-5$ \\
\hline
\end{tabular}

\subsection{Vermiculita termo expandida}

A vermiculita, que é um agregado de peso leve, produz um bom isolamento térmico e acústico no concreto, além de redução da massa específica. Na presença deste material ocorre uma redução do módulo de elasticidade, em razão da presença de uma grande quantidade de células de ar, característica essa de grande importância para o material que está sendo estudado.

Os concretos com vermiculita apresentam uma redução de, aproximadamente, $15 \%$ da massa específica do concreto convencional.

O nome vermiculita vem do latim "vermiculare”, pois ao ser aquecida quando do processo de fabricação, sua aparência lembra a de "vermes".

A vermiculita é um material bastante semelhante à mica, formada essencialmente por silicatos hidratados de alumínio e magnésio. Quando submetida a um aquecimento adequado, a água contida entre suas milhares de lâminas se transforma em vapor, fazendo com que as partículas explodam e se transformem em blocos sanfonados. Cada bloco expandido aprisiona consigo células de ar, o que confere ao material excepcional capacidade de isolação.

Quando submetida a altas temperaturas, a vermiculita perde água intersticial e as lâminas se expandem, transformando-se em flocos que formam células de ar, que lhe proporcionam um bom isolamento termo-acústico e baixa massa específica. Em seu estado bruto possui a cor escura, sendo que após aquecimento e expansão passa a ter coloração dourada, como pode ser visualizado na Figura 2.1. 

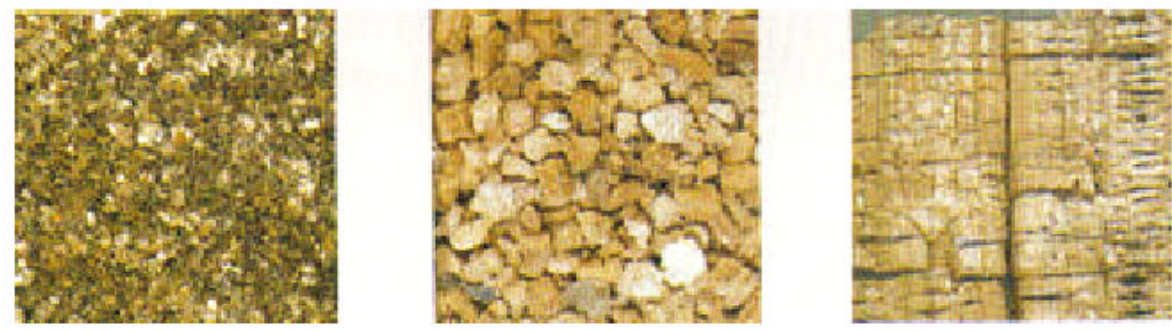

Figura 2.1 - Vermiculita: natural, expandida e partícula expandida

O produto é inífugo, inodoro, não irrita a pele nem os pulmões, não conduz eletricidade, é isolante térmico e absorvente acústico; não se decompõe, deteriora ou apodrece; não atrai cupins ou insetos; é somente atacado pelo ácido fluorídrico a quente; pode absorver até cinco vezes a sua massa em água, é lubrificante e tem as características necessárias aos materiais filtrantes.

A vermiculita pode ser encontrada em diversas partes do mundo, sendo que as primeiras jazidas até hoje exploradas se encontram na África do Sul e nos Estados Unidos e com relação à sua produção mundial, destaca-se que esta já superou a marca de 800 mil toneladas, segundo dados do ano de 1997.

A descoberta de grandes reservas no Brasil Central possibilitou o mercado interno de vermiculita, assim como os mais diversos produtos derivados daquela matéria-prima.

Dentre os principais usos na construção civil, destaca-se a sua aplicação como eficiente isolante acústico, em razão da baixa condutividade térmica e baixa propagação sonora, além da freqüente utilização como redutor de peso de estruturas de concreto em função de sua reduzida massa específica.

A vermiculita também é bastante utilizada na produção de tijolos refratários, de blocos e placas de cimento resistentes a altas temperaturas, na proteção de estruturas de aço contra altas temperaturas e como enchimento para isolamento térmico nas construções.

Ela é também utilizada em outras importantes aplicações, tais como: retardamento contra fogo, elemento filtrante, peneira molecular, embalagem de materiais e equipamentos frágeis, aumento da viscosidade de óleos lubrificantes, absorvente de umidade e contaminações fluidas, ingredientes de compostos de vedação de juntas de dilatação, excipientes de agentes de nutrição animal e vegetal, medicamentos e defens ivos agrícolas. 
A vermiculita utilizada na confecção das almofadas estudadas nesta dissertação é a do tipo termo-expandida.

\subsection{Utilização de polímeros em argamassas e concretos}

\subsubsection{Polímeros}

Polímero é uma longa molécula composta por muitas pequenas unidades (monômeros), juntadas e terminadas (MANO, 1985). Este termo, polímero, vem do grego $($ poli $=$ muitos; meros $=$ partes $)$. São consideradas polímeros aquelas moléculas relativamente grandes, de pesos moleculares da ordem de $10^{3}$ a $10^{6}$, em cuja estrutura se encontram repetidas unidades químicas simples conhecidas como meros.

Polimerização é a reação química que conduz à formação do polímero, ou seja, a ligação de pequenas moléculas umas às outras para formar moléculas maiores (MANO, 1985).

\subsubsection{Látex estireno-butadieno (SB)}

O látex foi referenciado pela primeira vez no início do século XVII, quando índios da América do Sul produziam calçados com características elásticas com látex obtido de árvores conhecidas como seringueiras (hevea brasilienses) (WALTERS, 1987). Dessa forma, o termo látex foi utilizado originalmente para designar o produto natural da seringueira, constituído de partículas de borracha sólida dispersas em água.

Atualmente, látex é a designação de uma suspensão coloidal do polímero em água, contendo cerca de $50 \%$ em peso de partículas esféricas muito pequenas de polímero, mantidas em suspensão na água por agentes tenso-ativos (MEHTA \& MONTEIRO, 1994).

O látex pode ser concentrado ou diluído e pode receber pequenas quantidades de conservantes (para prevenir a contaminação de bactérias e melhorar a resistência final), estabilizadores e/ou anti-espumantes (para reduzir a quantidade de ar incorporado).

Com exceção do látex de resina epóxi, os látex são produzidos pelo processo de polimerização em emulsão. O processo envolve a mistura de um ou mais monômeros com água, estabilizador e um catalisador. Durante o processo, ainda podem ser 
incorporados produtos para controlar o $\mathrm{pH}$, o tamanho das partículas, o teor de ar incorporado etc (STORTE, 1991).

\subsubsection{Argamassas modificadas com látex}

Os concretos e argamassas de cimento Portland são materiais de construção excepcionais, porém apresentam certas deficiências como permeabilidade, devido à sua porosidade, e a absorção de deformações provocadas por esforços solicitantes.

Para melhoria destas propriedades em concretos e argamassas existem pesquisas em todo mundo de novos materiais, com grande destaque para os polímeros.

Os polímeros, em geral, podem ser utilizados em argamassas e concretos como aglomerantes em substituição d cimento Portland (argamassas e concreto resina), podendo ser impregnados (argamassas e concretos impregnados) e também sendo adicionados à mistura do concreto (argamassas e concretos modificados).

As argamassas e concretos resinas são materiais formados por uma matriz de polímero e filler, preparado pela mistura completa de uma matriz polimerizável e agregados, seguida da polimerização "in situ”.

Os concretos e argamassas impregnados com polímeros são materiais em que é feita a impregnação de monômeros de baixa viscosidade por imersão e saturação, sendo estes posteriormente polimerizados com aplicação de calor ou raio gama. A baixa viscosidade é importante para que seja facilitada a impregnação.

As argamassas e concretos polímeros modificados são obtidos, quando no processo de mistura, com o material fresco e são adicionados polímeros ou monômeros, sendo realizada a cura e polimerização. Dentre as formas de utilização de polímeros em concretos e argamassas, esta apresenta grande vantagem, pois não necessita de mudanças significativas na tecnologia e processo de produção e nem a utilização de equipamentos especiais (ROSSIGNOLO, 1999).

A melhoria nas propriedades de argamassas e concretos de cimento Portland é obtida pela diminuição na quantidade e redução no diâmetro de poros capilares e aumento das forças de ligação entre o agregado e a matriz hidratada de cimento.

Por meio de análise microestrutural de argamassas e concretos modificados com polímero, pode-se observar a formação de pontes de polímeros através de microfissuras, 
restringindo a propagação destas. Nota-se também uma forte ligação entre a matriz aglomerante e os agregados. Estes são os principais motivos pelos quais os concretos e argamassas modificados adquirem uma maior resistência à tração (ROSSIGNOLO, 1999).

BIJEN (1993) observou uma melhora no desempenho do cimento reforçado com fibras de vidro pela adição de látex. Após processo de cura adequada, o pesquisador submeteu-as a processo de hidratação convencional acelerada, correspondendo a dez anos de exposição, de acordo com procedimentos descritos por LITHERLAND et al. (1981), obtendo resultados satisfatórios.

Esse autor apresenta as seguintes hipóteses para explicar a melhora na durabilidade da modificação referida:

a) Redução da água livre sob condições práticas (diminuição da água livre, por conseqüência);

b) Proteção da fibra contra o crescimento da cal, quando utilizada;

c) Redução do ataque alcalino (o polímero forma um filme que protege a fibra, ao menos parcialmente).

Segundo AFRIDI et al. (1989), a modificação por meio de polímero reduz a presença de hidróxido de cálcio, $\mathrm{Ca}(\mathrm{OH})_{2}$, possivelmente devido à adsorção deste entre os filmes de polímero, de modo que as camadas de filme de polímero "blindam" o $\mathrm{Ca}(\mathrm{OH})_{2}$.

OHAMA (1998) destaca que os requisitos gerais esperados na modificação do concreto e argamassa com látex são:

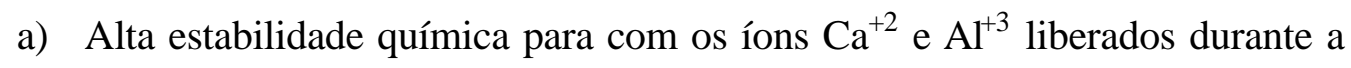
hidratação do cimento;

b) Grande estabilidade mecânica;

c) Redução do ar incorporado por meio do uso de aditivos para esse fim;

d) Influência não adversa à hidratação do cimento;

e) Formação de um filme de polímero contínuo em concreto ou argamassa, aderindo aos produtos de hidratação do cimento e à sílica dos agregados;

f) Excelente resistência à umidade e ao ataque do meio alcalino do cimento, aumentando a durabilidade. 
A modificação das argamassas e dos concretos de cimento Portland com polímeros é determinada tanto pela hidratação do cimento como pelo processo de formação do filme de polímero em sua fase de deposição. A hidratação do cimento, em geral, precede o processo de formação do filme de polímero, pela coalescência das partículas de polímero. Em ambos os casos, a fase co-matriz é formada na hidratação do cimento e no processo de formação do filme de polímero. A fase co-matriz é geralmente formada de acordo com o modelo simplificado mostrado na Figura 2.2.

(a) imedatamente apos a mistura

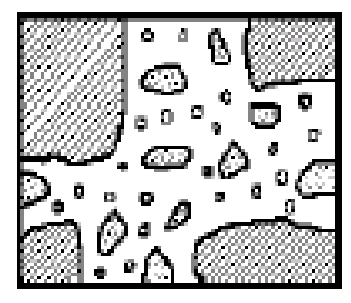

(b) primeira passo

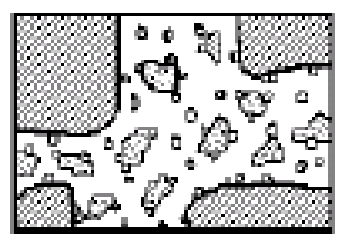

(c) segundo passo

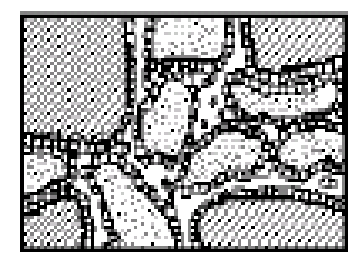

(d) terceiro passo

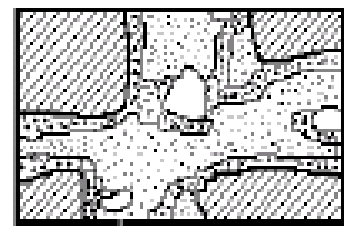

\section{partículas de cimento não hidratadas}

- partículas de polínero

agregados

[a ร́gua ecupa as espaços

intersticia's:

ơ das de cimento,gel de cimento (nesta fase, ocorre uma deposiças parcial das particulas de polimero)

mistura de gel de cimento e partinăo hidratadas de cimento envelopadas com una camada de particulas de polimero

particula de cinento hidratado

envolvida com filme de palimero

ar aprisionado

Figura 2.2 - Modelo idealizado de formação do concreto de cimento polímero

(OHAMA, 1998 apud. PERUZZI, 2002) 
A Figura 2.3 ilustra o modelo idealizado do processo de formação do filme de polímero na partícula de cimento hidratado.

De acordo com OHAMA (1998) as microfissuras na argamassa ou concreto modificados sob tensão são ligadas através dos filmes de polímero ou membranas formadas, o que previne a propagação de fissuras e, simultaneamente, desenvolve uma forte ligação entre o cimento hidratado e o agregado. Dessa forma, as propriedades das argamassas ou concretos de cimento Portland são geralmente melhoradas em grande escala pela modificação com o látex.

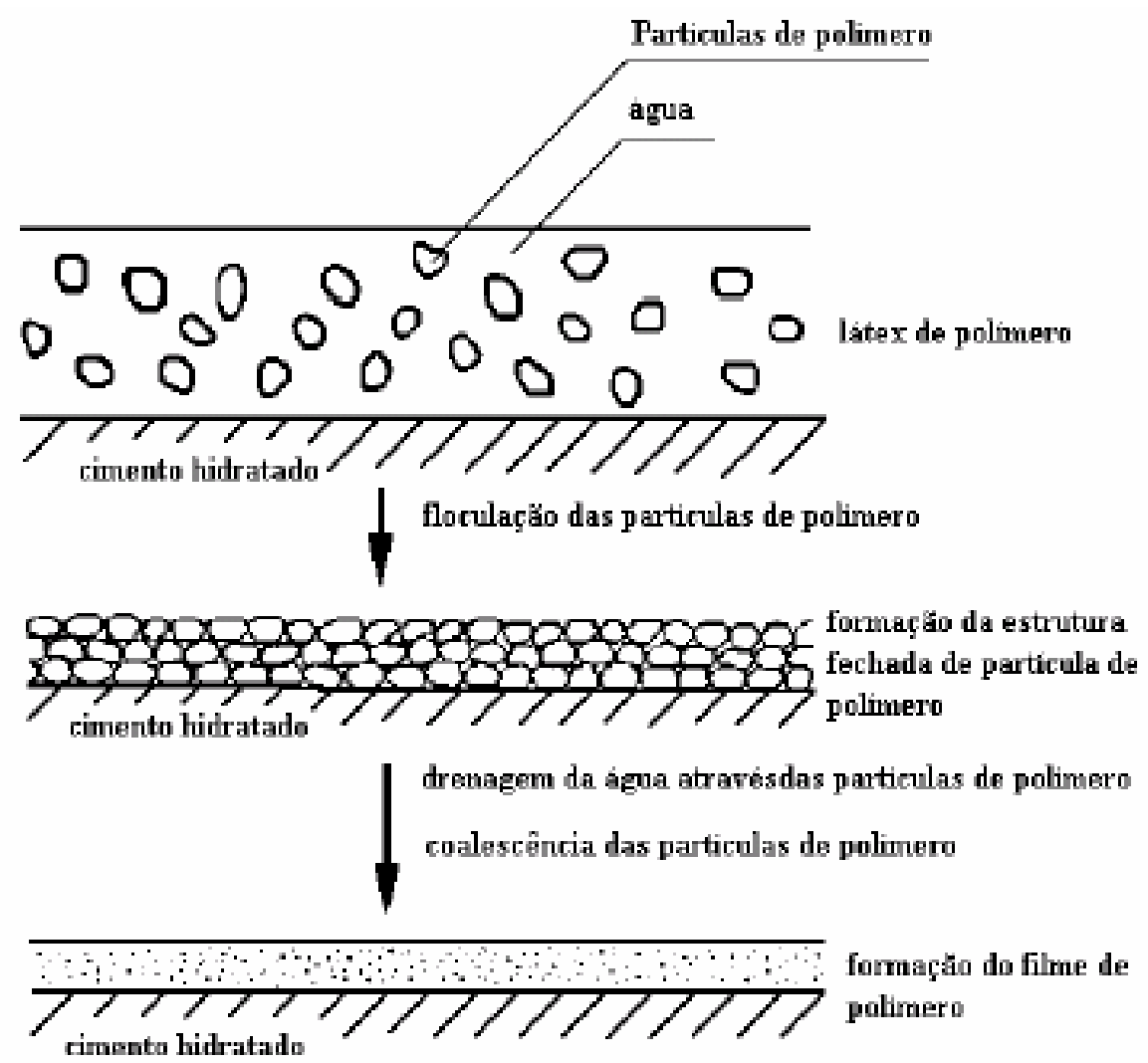

Figura 2.3 - Modelo idealizado do processo de formação do filme de polímero na partícula de cimento (STORTE, 1991 apud. PERUZZI, 2002)

Dentre as propriedades melhoradas nas argamassas e concretos modificados com polímeros, especialmente látex estireno-butadieno, estão a consistência, incorporação de ar, resistências mecânicas, permeabilidade, abrasão e retração por secagem. 
A adição de látex em argamassas de cimento Portland promove a melhoria de sua trabalhabilidade, efeito este causado pela adição de partículas de polímeros que funcionam como esferas lubrificantes, reduzindo a relação água/cimento.

O teor de ar incorporado por argamassas e concretos de cimento Portland modificados com látex é aumentado de forma considerável pela ação dos estabilizadores do látex, no entanto, apesar da incorporação de ar diminuir a resistência à compressão, ela promove uma melhora considerável na absorção de deformações.

Além disso, sua adição à argamassa melhora as seguintes propriedades do material no estado endurecido: durabilidade, flexão, resistência ao impacto, permeabilidade, resistência ao resfriamento e resistência à abrasão.

As argamassas e concretos modificados com látex também apresentam melhora na resistência à compressão, resistência à tração e redução do módulo de elasticidade em relação às argamassas e concretos convencionais, como conseqüência de reações químicas de grupos reativos presentes no látex, íons metálicos e sais na superfície do gel de cimento e dos agregados.

\subsection{Fibras}

Nos concretos e nas argamassas de cimento Portland também podem ser adicionadas fibras.

Os materiais reforçados com fibras, pelo aumento da ductilidade da matriz de cimento, têm apresentado uso crescente na Construção Civil.

Em diversos países, componentes de construção com materiais fibrosos são normalmente encontrados em edificações e obras de arte, tornando-se disponíveis até mesmo para compra em casas de materiais de construção.

No Brasil, seu uso começou de forma tímida na década de 1980, havendo um aumento considerável na década seguinte, visto que as empresas de grande porte passaram a adotar esses produtos em seus sistemas construtivos.

O reforço de argamassas e concretos de cimento Portland com fibras é uma maneira bastante eficiente de reduzir a fragilidade na ruptura destes materiais, aumentar a durabilidade e conferir propriedades mecânicas não encontradas nas argamassas e 
concretos convencionais, relacionada à capacidade de deformação e absorção de energia.

As propriedades mecânicas dos materiais reforçados com fibras podem ser explicadas a partir das características de sua microestrutura. Em MEHTA e MONTEIRO (1992), destaca-se que pelo estudo da microestrutura, obtém-se a resposta para a influência do tipo de fibra, idade de hidratação e relação água/cimento e de como esses fatores devem ser devidamente definidos a fim de que haja uma dosagem racional do compósito a ser empregado na prática.

Quando se trata de ensaios com materiais fibrosos, destaca-se que durante o carregamento do material, a tensão na qual ocorre a primeira fissura da matriz costuma aumentar com a aderência e, ainda, com a relação comprimento-diâmetro e concentração de fibras. Ao se elevar a aderência, obtém-se um acréscimo da resistência à tração na fase elástica de solicitação e, em alguns casos, a redução da ductilidade. Assim sendo, os ensaios a serem empregados devem auxiliar a escolha da situação ótima, na qual se compatibilizam tenacidades elevadas e resistências aceitáveis.

A maior aderência fibra-matriz, por sua vez, pode ser obtida a partir de reduções da porosidade e da concentração de portlandita (hidróxido de cálcio). Além disso, a utilização de fibras de perfil irregular confere acréscimos de até $10 \%$ para a resistência à tração do compósito, ao ser comparada à resistência obtida com fibras cilíndricas e lisas (BENTUR; MINDESS; DIAMOND, 1985c).

SAVASTANO JR. (1994), destaca ainda que as características das fibras não são as únicas responsáveis pelo melhor desempenho dos compósitos. Acréscimos na resistência à tração, deformação específica e ductilidade podem ser obtidos através do proporcionamento adequado de agregados (como a utilização de vermiculita, por exemplo), da relação água/cimento e de outras adições.

Existem vários tipos de fibras, que podem ser divididas em dois grupos: as que possuem um nódulo de elasticidade menor do que o da matriz de cimento, como a celulose, o nylon e o polipropileno; e as que possuem um módulo maior, como o amianto, o vidro, o aço, o carbono e o Kevlar.

Segundo TEZUKA (1989), as fibras de polipropileno, que têm módulo de elasticidade menor e alongamento maior do que as da matriz de cimento, dão 
compósitos com pequeno aumento de resistência, mas capazes de absorver grandes energias e, portanto, grande resistência ao impacto e tenacidade.

As fibras de módulo de elasticidade elevado e grande resistência, tais como as fibras de vidro, aço e carbono, produzem, geralmente, compósitos com alta resistência à tração e absorção de cargas dinâmicas, dependendo da quantidade incorporada.

Destaca-se que as fibras podem ser produzidas como monofilamentos ou com ganchos nas extremidades (fibra de aço), sendo a função destes melhorar a iteração entre as fibras e a matriz de cimento Portland.

A eficiência das fibras na matriz frágil, proporcionando uma melhora nas propriedades mecânicas, depende da transferência de tensões da matriz para as fibras, ou seja, quanto maior a transferência de tensão de tração melhor a eficiência. Destaca-se ainda que a eficiência das fibras depende do cruzamento das fissuras pelas fibras nos estágios mais avançados do carregamento.

A transferência de tensões tem efeitos muito diferentes nos estados de préfissuração e pós- fissuração.

No primeiro estado, a transferência de tensões é de natureza elástica e as deformações na interface matriz-fibra são iguais. No estado mais avançado do carregamento, ou seja, no estado de pós-fissuração, ocorre a ruptura da adesão entre a fibra e a matriz de cimento e a transferência de tensões na interface entre os dois materiais passa a ser realizada por tensões de atrito, aparecendo deslocamentos longitudinais entre a fibra e a matriz.

A principal contribuição da adição de fibras nos concretos e argamassas de cimento Portland é no estado de pós-fissuração, em que podem desempenhar duas funções: aumentar a resistência do compósito, transferindo tensões através de fissuras; e aumentar a tenacidade por fornecer mecanismos de maior absorção de energia, pelo alongamento e deslocamento das fibras. Em se trabalhando tridimensionalmente, na matriz de cimento Portland detém-se as microfissuras a partir do início de sua formação. A fissuração plástica é provocada pelo assentamento e/ou pela retração devido à rápida evaporação da água de amassamento.

As fibras atuam interceptando as microfissuras, absorvendo e dispersando a energia que, uma vez sem controle, produz um quadro patológico de fissuras e trincas próprias de todas as massas que contenham o cimento Portland. O importante advento 
da interceptação das microfissuras, em seu estágio inicial, é obtido pela disseminação de milhares de fibras, interconectadas, que formam uma armadura em forma de rede tridimensional.

Segundo BALAGURU \& SHAH (1992) os principais parâmetros que afetam a interação fibra- matriz são:
a) Condição da matriz (fissurada ou não);
b) Composição da matriz;
c) Geometria da fibra;
d) Tipo de fibra (metálica, polimérica, vidro etc);
e) Características da superfície da fibra;
f) Rigidez da fibra em comparação com a da matriz;
g) Orientação das fibras (alinhadas ou distribuídas aleatoriamente);
h) Quantidade de fibras adicionadas;
i) Velocidade de carregamento;
j) Durabilidade das fibras no compósito.

Segundo GUIMARÃES (1999), maiores resistências à compressão geralmente resultam em rupturas mais frágeis, tanto para argamassas e concretos convencionais quanto para aqueles reforçados com pequenas quantidades de fibras. Maiores quantidades de fibras deverão ser adicionadas conforme se aumenta a resistência à compressão das argamassas ou dos concretos, a fim de que esses possam produzir ruptura dúctil.

\subsubsection{Fibra de PVA}

A fibra de PVA apresenta uma alta resistência, alto módulo de elasticidade, resistência à abrasão, à álcalis, aos ácidos e uma boa resistência térmica. Esta fibra é um substituto ideal do amianto e da fibra de vidro, tornando-se, assim, uma ótima alternativa.

\subsubsection{Fibra de polipropileno}

A fibra de polipropileno é formada de macrocélulas lineares saturadas de hidrocarbonetos das quais um carbono, entre cada dois, comporta uma ramificação metila, em disposição estática e sem substituições ulteriores. Esta fibra incorporada ao 
concreto reduz substancialmente as fissuras de retração plástica, reduz a permeabilidade e promove o aumento da resistência ao impacto, à abrasão e ao congelamento, proporcionando aumento da durabilidade do concreto, além de aumentarem a resistência à fadiga e a fragmentação.

Ainda são reduzidos os estudos sobre a zona de transição entre fibras de polipropileno e pasta de cimento Portland. Como possibilidade de utilização destacamse as fibras fibriladas e a utilização de aditivos redutores de água para a matriz, já que as fibras fibriladas tendem a incorporar significativo volume de vazios, o que acaba por anular o efeito positivo do aumento da área superficial de contato com a matriz, no caso de fibras curtas (CURRIE; GARDINER, 1989).

\subsubsection{Fibra de vidro}

Embora as fibras de vidro sejam confeccionadas com material frágil - o vidro elas possuem propriedades satisfatórias para serem empregadas na construção civil, que são: baixo coeficiente de dilatação térmica, resistência à tração e à vibração, retenção das propriedades mecânicas a altas temperaturas, grande alongamento na ruptura, facilidade de processamento, baixo custo se comparada às outras fibras dúcteis, além de não serem passíveis de inalação, o que representa uma grande vantagem se comparada ao amianto. A justificativa para a maior resistência das fibras de vidro em relação ao vidro está na menor quantidade de defeitos microscópicos que a primeira possui em relação ao segundo, defeitos esses que são responsáveis pelo enfraquecimento dos materiais (OLIVEIRA \& AGOPYAN, 2000).

A fibra de vidro tipo E, comumente chamada convencional, tem inadequada resistência ao meio alcalino da matriz de cimento Portland, causando uma deterioração das propriedades mecânicas e fazendo com que a fibra de vidro convencional perca sua flexibilidade e sua resistência à tração, o que fragiliza todo o compósito. Para contornar a degradação das fibras de vidro, tem-se duas alternativas: $1^{\mathrm{a}}$ ) melhoria da resistência das fibras, por meio do uso de fibra de vidro AR [álcali resistente] ou do preparo da sua superfície; $2^{\mathrm{a}}$ ) modificação das matrizes de cimento (PURNELL et al, 2000).

Essas fibras são materiais amorfos e sua cristalização ocorre depois de prolongado tratamento com altas temperaturas (PURNELL et al, 2000). 
As adições dos materiais anteriormente citados (vermiculita, látex estirenobutadieno e fibras) tendem a reduzir o módulo de elasticidade do material, característica esta que é considerada como uma espécie de efeito colateral, no entanto, é completamente importante para o material ser utilizado como material de enchimento. 


\section{CARACTERIZAÇÃO DOS MATERIAIS E ENSAIOS REALIZADOS}

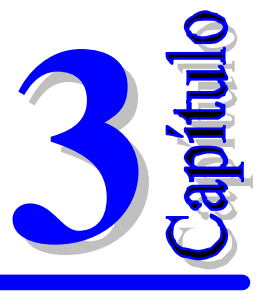

\subsection{Preliminares}

Neste capítulo tratar-se-á, especificamente, dos materiais, métodos e técnicas relacionados aos ensaios.

Dessa forma, tratar-se-á, inicialmente, das características dos materiais a serem utilizados nas moldagens dos corpos-de-prova e almofadas; em seguida, discorrer-se-á o planejamento experimental dos ensaios, com tabelas, referências e formas de realização.

\subsection{Materiais}

Neste item, tratar-se-á, especificamente, dos materiais a serem utilizados para a confecção dos corpos-de-prova e almofadas do compósito que vem sendo desenvolvido, indicando procedência, resistências, cor, aspecto e outras características relevantes aos materiais referenciados.

\subsubsection{Cimento Portland}

O cimento utilizado nos experimentos foi o de alta resistência inicial, CP V ARI PLUS, produzido pela HOLCIM S.A., cujas características podem ser observadas na Tabela 3.1. 
Tabela 3.1 - Características do cimento utilizado (Fonte: HOLCIM S.A.)

\begin{tabular}{||c|c|c||}
\hline Características & Unidade & CP V ARI \\
\hline Finura de Blaine (NBR 7224/1984) & $\mathrm{cm}^{2} / \mathrm{g}$ & 4687 \\
\hline Início de Pega (NBR 11581) & $\mathrm{min}$ & 130 \\
\hline Fim de Pega (NBR 11581) & $\mathrm{min}$ & 210 \\
\hline Resistência 1 dia (NBR 7215/1982) & $\mathrm{MPa}$ & 27,7 \\
\hline Resistência 3 dias (NBR 7215/1982) & $\mathrm{MPa}$ & 42,0 \\
\hline Resistência 7 dias (NBR 7215/1982) & $\mathrm{MPa}$ & 46,7 \\
\hline Resistência 28 dias (NBR 7215/1982) & $\mathrm{MPa}$ & 56,1 \\
\hline
\end{tabular}

\subsubsection{Areia}

A areia utilizada na pesquisa foi retirada do rio Mogi Guaçu, próximo a São Carlos. Amostras dessa areia foram ensaiadas no intuito de se obter a curva granulométrica, a massa unitária e a massa específica do agregado. A massa específica de um agregado é a relação entre a sua massa e o seu volume, não levando em consideração os vazios permeáveis à água. Já a massa unitária de um agregado é a relação entre a sua massa e o seu volume sem compactar, considerando-se como volume também os vazios entre os grãos. Segundo a ABCP (2000a), esse é o parâmetro tido como próprio para transformar massa em volume ou vice-versa, para proporcionamento dos agregados em volume durante a preparação do concreto. A massa específica da areia vale $2,63 \mathrm{~g} / \mathrm{cm}^{3}$. Já sua massa unitária tem como valor $1,50 \mathrm{~g} / \mathrm{cm}^{3}$. Para determinação desses parâmetros, seguiram-se as prescrições da NBR 7251 (1982) e da NBR 9776 (1987). A curva granulométrica da areia utilizada é apresentada na Figura 3.1 .

O diâmetro máximo característico da areia é igual a 2,4mm e seu módulo de finura equivale a 2,29 . 


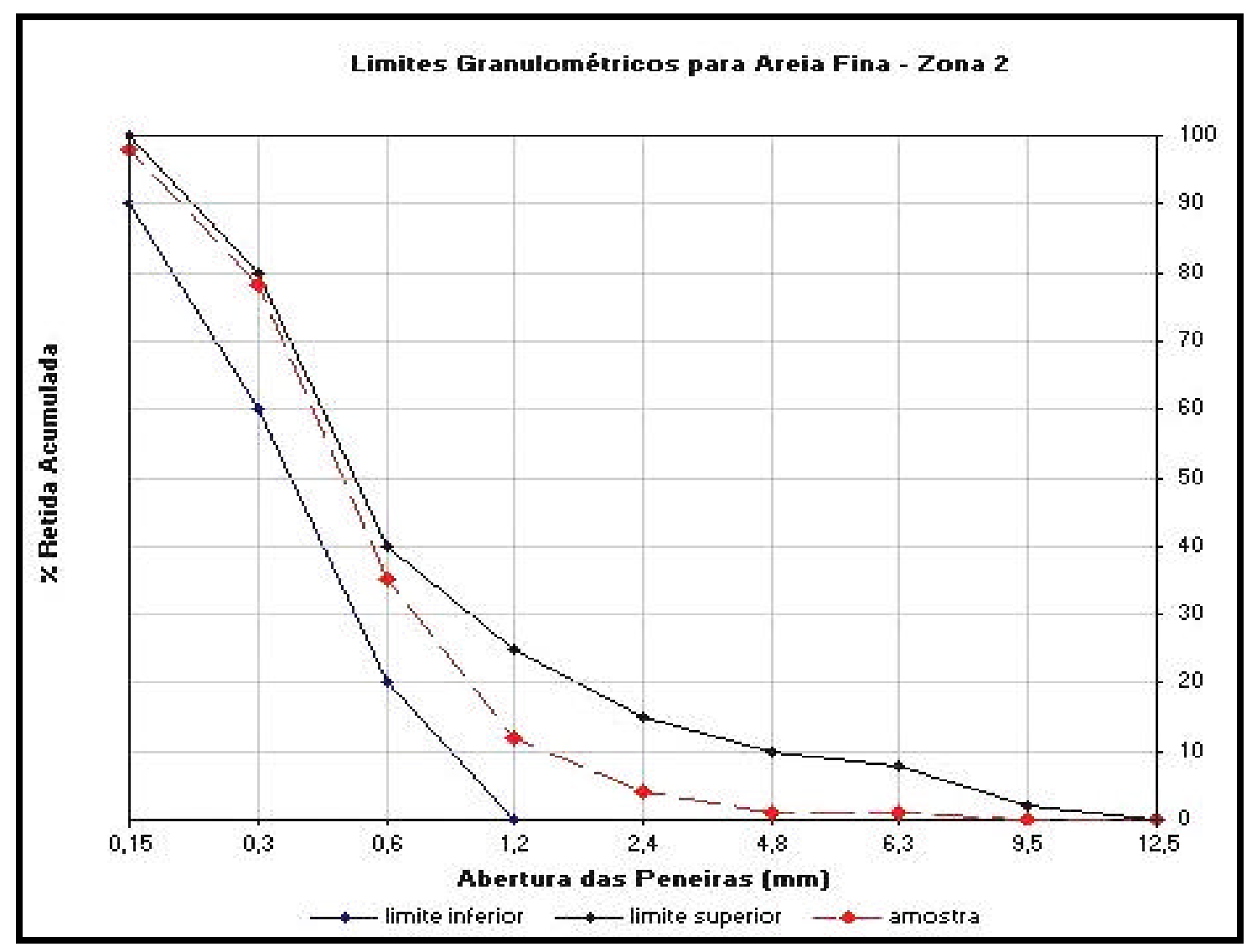

Figura 3.1- Curva granulométrica da areia utilizada

\subsubsection{Vermiculita termo-expandida}

Alguns ensaios com vermiculita foram realizados na Escola de Engenharia de São Carlos. Em seu trabalho de iniciação científica, MACETTO (2001) realizou ensaios em duas amostras de vermiculita, nos quais o autor observou a diferença na dimensão máxima dos grãos.

Uma amostra continha grãos que foram retidos na peneira com abertura de 4,8mm, sendo classificado como agregado graúdo e a outra amostra estudada possuía grãos visualmente menores que $4,8 \mathrm{~mm}$, não sendo retidos na peneira com esta malha, sendo classificado, portanto, como agregado miúdo.

Realizados os ensaios de determinação granulométrica nas amostras, obtiveram-se as curvas granulométricas de cada uma delas utilizando um conjunto de peneiras padronizadas. 


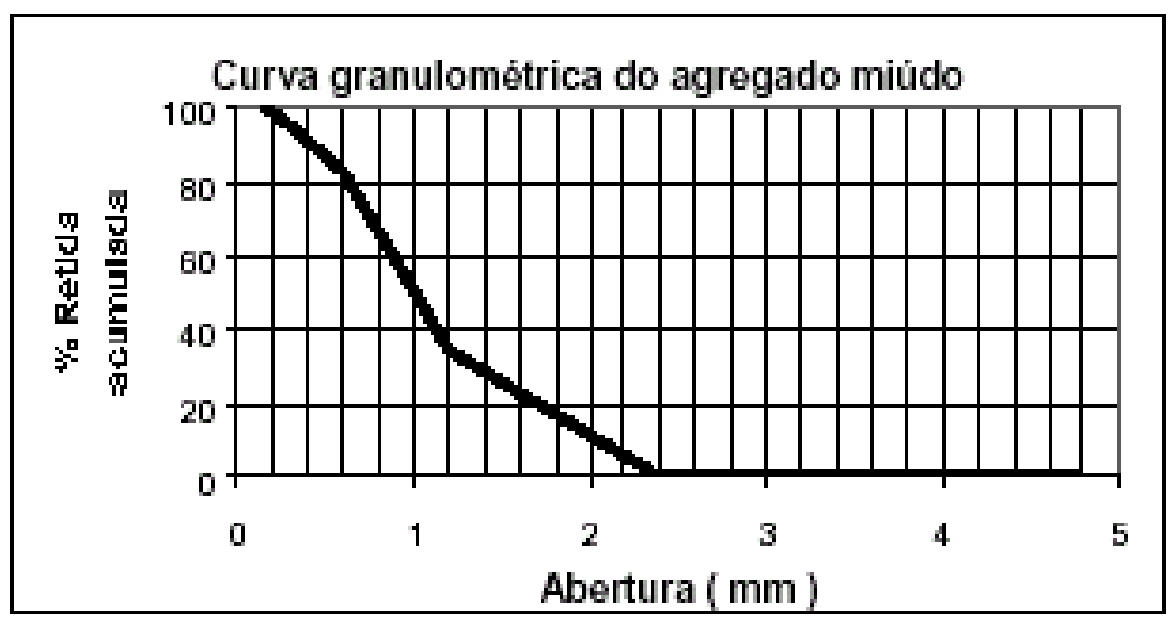

Figura 3.2- Curva granulométrica do agregado miúdo - vermiculita

(MACETTO, 2001)

Optou-se por utilizar o agregado miúdo para a realização das moldagens e ensaios referentes a este trabalho.

\subsubsection{Látex Estireno-Butadieno (SB)}

O látex utilizado nos experimentos foi o Estireno-Butadieno SB 112, fornecido pela empresa Rhodia e suas características são apresentadas na Tabela 3.2. Optou-se pela utilização deste tipo de emulsão de látex (50\% de água) em razão de sua disponibilidade no Laboratório de Estruturas.

Tabela 3.2 - Propriedades do Látex Estireno-Butadieno (Fonte: Rhodia)

\begin{tabular}{|c|c||}
\hline Propriedades & Valores \\
\hline Teor de sólidos $^{\circ}$ & $50 \%$ \\
\hline Massa específica a $\mathbf{2 5}^{\mathbf{C}} \mathbf{C}$ & $1,02 \mathrm{~kg} / \mathrm{dm}^{3}$ \\
\hline Viscosidade Brookfield (LVT $\mathbf{2 / 3 0}$ a 23 $\mathbf{C}$ ) & $300 \mathrm{cps}$ \\
\hline $\mathbf{p H}$ & 9,0 \\
\hline Estabilizador & Aniônico \\
\hline Aspecto & Leitoso \\
\hline
\end{tabular}

Quando incorporado à mistura, durante a moldagem dos corpos-de-prova e almofadas, atribui a esta uma cor roxa. 


\subsubsection{Aditivo Superplastificante}

Em razão de alguns traços não adquirirem a trabalhabilidade adequada, dificuldades para moldar a mistura, em alguns casos, tornourse necessária a utilização de aditivo superplastificante.

O aditivo utilizado é da empresa MBT Brasil Indústria e Comércio, cujas características são apresentadas na Tabela 3.3.

Este aditivo foi o SP 1, do tipo SPA e foi utilizado na taxa de, aproximadamente, $1 \%$ em massa para misturas com $25 \%$ ou $50 \%$ de vermiculita.

Tabela 3.3 - Propriedades do aditivo superplastificante (Fonte: MBT)

\begin{tabular}{||c|c|c||}
\hline Parâmetros & Unidade & SP 1 \\
\hline Massa específica & $\mathrm{g} / \mathrm{cm}^{3}$ & 1,11 \\
\hline pH & - & 8,89 \\
\hline Teor de sólidos & $\%$ & 16,49 \\
\hline Aspecto & - & líquido homogêneo \\
\hline Cor & - & castanho \\
\hline
\end{tabular}

\subsubsection{Fibras}

Optou-se pela utilização de três tipos de fibras de características distintas. As fibras utilizadas foram as de PVA, vidro e polipropileno, sendo que os seus respectivos comprimentos eram $12 \mathrm{~mm}, 13 \mathrm{~mm}$ e $25 \mathrm{~mm}$. A massa específica equivalente é $1,3 \mathrm{~g} / \mathrm{cm}^{3}$ (EL DEBS \& EKANE, 1998) para a primeira, 2,67g/cm ${ }^{3}$ (FIORELLI, 2002) para a segunda e para a última, a de polipropileno, 0,9g/cm³ (EL DEBS \& EKANE, 1998).

Com relação à incorporação à mistura, salienta-se que a fibra de polipropileno é pior que as demais, visto que esta promove dificuldades ao moldar e também durante o processo de vibração para o adensamento da mistura, sobretudo em razão do seu comprimento, considerado grande para utilização em placas do referido compósito de pequenas dimensões, sobretudo no que diz respeito à espessura. Sendo assim, este tipo de fibra foi pouco utilizado, um traço, apenas com o intuito de verificar as características do compósito em quantidades bem pequenas de vermiculita (5\%).

Já as fibras de PVA e de vidro possuem condições de trabalhabilidade praticamente idênticas, sendo necessário utilizar aditivo superplastificante em traços 


\subsection{Programa experimental}

Neste capítulo serão destacadas, inicialmente, as dosagens e características do compósito em questão, bem como as variáveis envolvidas nas composições. Na seqüência serão destacados os ensaios referentes à caracterização do material em corpos-de-prova cilíndricos (resistência à compressão, resistência à tração por compressão diametral e módulo de elasticidade), os ensaios nas almofadas (compressão e afundamento) e de ligações de blocos de concreto com ou sem a presença da almofada de apoio.

\subsubsection{Dosagem e características do compósito}

Para as misturas ensaiadas, utilizoutse o traço de referência mostrado na Tabela 3.5, o qual foi proposto por MACETTO (2001), após avaliação de diversas dosagens distintas utilizando cimento, areia, látex e água.

Tabela 3.5 - Traço de referência em massa

\begin{tabular}{||c|c|c|c||}
\hline Cimento & Areia & Látex & Água \\
\hline 1 & 0,3 & 0,3 & 0,1 \\
\hline
\end{tabular}

Tomou-se como base esse traço de referência com o objetivo de se obter um traço com maior resistência à compressão (relacionada, sobretudo, à quantidade de agregado), mantendo-se um baixo módulo de elasticidade (relacionado à emulsão de látex). Os traços são realizados com quantidades de 50\%, 25\%, 10\%, 5\% e 0\% da massa de agregados do traço de referência, sendo o restante composto por areia peneirada com diâmetro máximo $0,6 \mathrm{~mm}$.

Da tabela, deve-se levar em consideração que a quantidade de látex mencionado refere-se a uma emulsão e, dessa forma, praticamente metade dessa quantidade corresponde à água.

Nos traços que foram moldados, a quantidade de látex adicionada foi de 0\%, 20\%, $30 \%$ e $40 \%$ da massa de cimento utilizada, sendo que, na maioria dos casos, optou-se pela utilização do produto na taxa de $30 \%$, devido à boa trabalhabilidade e aos resultados satisfatórios. Destaca-se, ainda, que foram realizados diversos experimentos 
com o compósito utilizando quantidades do produto em massa superiores a $30 \%$, principalmente $40 \%$, entretanto, notou-se uma acentuada queda de resistência dos corpos-de-prova e optou-se por utilizar preferencialmente a quantidade de $30 \%$, sobretudo em função do valor do módulo de elasticidade.

A quantidade de fibras utilizada foi de $0 \%$ (sem fibra), $1 \%, 2 \%, 3 \%$ e $4 \%$ do volume de massa de compósito, sendo que a última taxa foi muito pouco utilizada, pois seus resultados pouco diferiam dos mesmos corpos-de-prova com $3 \%$ de fibras e, sobretudo, devido às dificuldades de moldagem com grandes quantidades do material, prejudicando a trabalhabilidade.

A quantidade de água a ser adicionada variava de acordo com as quantidades de látex adicionadas. Utilizava-se a porção líquida (água + látex) na taxa de 0,4 vezes a quantidade de cimento; sendo assim, quando se utilizava, por exemplo, 30\% de látex, utilizava-se água na taxa de $10 \%$. Entretanto, devido às dificuldades na moldagem, no caso de se utilizar $40 \%$ de látex, adicionourse $10 \%$ de água, para que a mistura pudesse atingir a fluidez necessária e pudesse passar pelo processo de vibração/adensamento de forma adequada.

Ressalta-se, também, que ms casos em que se empregavam grandes quantidades de vermiculita $(25 \%$ e $50 \%)$, devido à grande capacidade de retenção de água deste material, tornava-se necessária a utilização de aditivo superplastificante. No primeiro caso ( $25 \%$ de vermiculita), utilizou-se uma taxa de $0,9 \%$ e nas misturas com $50 \%$ de vermiculita, utilizou-se uma taxa de, aproximadamente, $1,2 \%$ de superplastificante.

O cimento utilizado foi do tipo ARI PLUS, portanto cimento de alta resistência inicial (CP V ARI). Para o cálculo do consumo de cimento utilizou-se a equação 3.1, que se encontra a seguir.

$$
\begin{gathered}
C=\frac{1000}{\frac{1}{\rho_{c}}+\frac{0,3}{\rho_{a}}+0,3+0,1} \quad \text { eq. (3.1) } \\
\text { onde: } \begin{array}{l}
\rho_{c}=\rho_{\text {cimento }}=3,12 \mathrm{~g} / \mathrm{cm}^{3} \\
\rho_{a}=\rho_{\text {areia }}=2,63 \mathrm{~g} / \mathrm{cm}^{3}
\end{array}
\end{gathered}
$$


A curva granulométrica da areia, módulo de finura, dimensão máxima do agregado, massa unitária e massa específica são apresentados no capítulo 3.2.2 deste trabalho.

Inicialmente, calcula-se o volume de corpos-de-prova ou placas a serem moldados nas fôrmas e, a este volume, atribui-se a designação $V_{c p s}$.

Tem-se, então, a quantidade de cimento $\alpha$ calculada da seguinte forma:

Quantidade de cimento: $C . V_{c p s}=\alpha \quad e q$. (3.2)

Com base na quantidade de cimento $(\alpha)$, calculam-se as quantidades dos demais componentes da mistura, como se pode ver a seguir.

Areia: $0,3 \alpha \quad$ eq. (3.3)

Látex: $0,3 \alpha \quad$ eq. (3.4)

Água: $0,1 . \alpha \quad e q .(3.5)$

Fibra: $V_{c p s} \cdot \rho_{f} \cdot F \quad$ eq. (3.6)

Sendo que: $\rho_{\mathrm{f}}=1,3 \mathrm{~g} / \mathrm{cm}^{3}$ (fibra de PVA)

$$
\begin{aligned}
& \rho_{f}=2,67 \mathrm{~g} / \mathrm{cm}^{3} \text { (fibra de vidro) } \\
& \rho_{\mathrm{f}}=0,9 \mathrm{~g} / \mathrm{cm}^{3} \text { (fibra de polipropileno) } \\
& \mathrm{F}=\text { quantidade de fibra a ser acrescentada }
\end{aligned}
$$

Com relação a vermiculita, a quantidade desta é calculada junto da quantidade de areia, sendo que a quantidade da primeira, em massa, deve ser subtraída da quantidade da segunda. Outra observação importante com relação a vermiculita é que quando se utiliza esta, deve-se acrescentar a sua participação na equação do consumo de cimento (eq. 3.1), dando origem à equação 3.7.

$$
\mathrm{C}=\frac{1000}{\frac{1}{\rho_{\mathrm{c}}}+\frac{0,3-\mathrm{a}}{\rho_{\mathrm{a}}}+\frac{\mathrm{a}}{\rho_{\mathrm{v}}}+0,3+0,1} \quad \text { eq. (3.7) }
$$

onde: $\rho_{\mathrm{v}}=\rho_{\text {vermiculita }}=0,356 \mathrm{~g} / \mathrm{cm}^{3}$

$$
\mathrm{a}=0,3 \text { vezes vermiculita eq. (3.8) }
$$


Deve-se ressaltar que as massas específicas da areia e da vermiculita são distintas. Para melhor compreensão destaca-se, na seqüência o traço V50L30VD2.

Neste caso a variável $a$ da equação 3.7 vale 0,15 e as massas específicas do cimento, da areia e da vermiculita tem os valores mostrados anteriormente. Sendo assim, tem-se um consumo de cimento de $834,70 \mathrm{~kg} / \mathrm{m}^{3}$. Esse consumo será multiplicado pelo volume total de argamassa dos corpos-de-prova a serem moldados e acrescido de $10 \%$, obtendo-se a massa de cimento a ser utilizada.

Ao se multiplicar essa massa de cimento pela variável $a$ (neste caso igual a 0,15 ) tem-se a massa de vermiculita a ser empregada na moldagem. Com relação à areia, a massa desse agregado a ser empregada corresponde à multiplicação $(0,3$ - a) vezes a massa de cimento. O látex terá sua massa dada pela multiplicação 0,3 vezes a massa de cimento e a água pela multiplicação 0,1 vezes a massa de cimento.

Como neste caso se utilizou fibra de vidro, para verificar a quantidade da mesma a ser empregada basta multiplicar o volume total de argamassa esperado por sua massa específica multiplicada pela taxa de fibra que se quer aplicar à mistura.

\subsubsection{Variáveis}

As variáveis em questão são a vermiculita, o látex e as fibras, conforme mostrado na Tabela 3.6.

Tabela 3.6 - Dosagem dos materiais

\begin{tabular}{||c|c|c|c|c|c||}
\hline Variáveis & \multicolumn{6}{|c||}{ Dosagem (\%) } \\
\hline Vermiculita & $\mathbf{5 0}$ & $\mathbf{2 5}$ & $\mathbf{1 0}$ & $\mathbf{5}$ & $\mathbf{0}$ \\
\hline Látex & \multicolumn{2}{|c|}{0} & 20 & $\mathbf{3 0}$ & 40 \\
\hline Fibras & 0 & 1 & 2 & $\mathbf{3}$ & 4 \\
\hline
\end{tabular}

As misturas que foram utilizadas como base possuíam as quantidades de materiais destacadas em negrito. Essas misturas foram tomadas como base por atribuírem à argamassa, em ensaios realizados previamente, características importantes para um material a ser utilizado como de apoio. 
Algumas das características esperadas neste caso são: resistência tão alta quanto possível em corpos com baixo módulo de elasticidade, pouco rígidos, que não sofram ruptura frágil e que sejam capazes de acomodar as imperfeições mediante a aplicação de carga localizada. Enfim, um material suficientemente flexível e capaz de distribuir e regularizar as tensões nas ligações entre elementos pré-moldados de concreto.

A partir dessas dosagens, foram estabelecidas misturas dos 3 elementos (vermiculita, látex estireno-butadieno e fibra) acrescidos a uma argamassa de cimento e areia, variando as quantidades de cada um deles a cada nova mistura, sendo que os números destacados em negrito representavam quantidades que apareciam em todas as misturas estabelecidas.

Na tabela 3.7, pode-se observar a legenda e a descrição dos traços referentes a cada uma das misturas que vão sendo realizadas.

Tabela 3.7 - Legenda e Descrição dos Traços

\begin{tabular}{||c|c||}
\hline Legenda & Descrição \\
\hline V +número & Consumo de vermiculita (em \%) \\
\hline L + número & Taxa volumétrica de látex $(\mathrm{em} \%)$ \\
\hline F + número & Taxa volumétrica de fibra de PVA (em \%) \\
\hline VD + número & Taxa volumétrica de fibra de vidro $(\mathrm{em} \%)$ \\
\hline PP + número & Taxa volumétrica de fibra de polipropileno $(\mathrm{em} \%)$ \\
\hline
\end{tabular}

\subsection{Características do material}

Neste item serão abordadas algumas características do compósito: resistência à compressão, resistência à tração por compressão diametral e módulo de elasticidade.

Verificar-se-ão, inicialmente, as referidas características para, em seguida, utilizar os traços com as características de resistência e elasticidade mais apropriadas na preparação das almofadas que serão ensaiadas à compressão (rigidez) e ao afundamento (dureza).

O sub-capítulo, então, será dividido em cinco partes distintas: moldagem dos corpos, ensaios de compressão axial, ensaios de compressão diametral, ensaios para a obtenção do módulo de elasticidade e depuração dos resultados. 


\subsubsection{Preparação dos corpos-de-prova cilíndricos}

A moldagem dos corpos foi realizada no Laboratório de Estruturas da Escola de Engenharia de São Carlos. Neste caso, foram moldados corpos-de-prova cilíndricos de $5 \mathrm{~cm}$ de diâmetro e $10 \mathrm{~cm}$ de altura. Os corpos foram confeccionados em fôrmas metálicas cilíndricas para vários traços distintos e ensaiados à compressão diametral e axial e, ainda, compressão axial para a obtenção do módulo de elasticidade para cada traço diferente.

Para efetuar a moldagem dos corpos utilizaram-se equipamentos e dispositivos específicos existentes no Laboratório de Estruturas. Vale destacar que os corpos foram moldados numa determinada data e desmoldados 1 dia após a moldagem e, então, eram colocados na câmara úmida para que se estabelecesse a cura de 7 dias até o ensaio.

Na seqüência, são mostradas algumas fotos tiradas durante a moldagem de um traço específico (no caso, V5L30F3). Depois de realizadas as etapas mostradas nas Figuras 3.3a, 3.3b e 3.3c, a mistura era colocada, com auxílio da colher de pedreiro, nas fôrmas metálicas e passavam por um processo de adensamento em mesa vibratória e posterior acabamento com colher de pedreiro ou desempenadeira.

Moldavam-se 11 corpos-de-prova para cada traço, sendo 4 para o ensaio de resistência à compressão, 4 para o ensaio de resistência à tração por compressão diametral e 3 corpos para o ensaio de compressão axial para a determinação do módulo de elasticidade de cada traço.

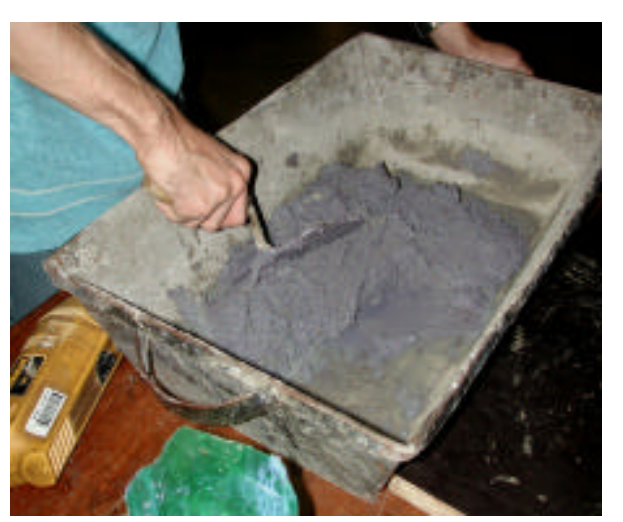

Figura 3.3a - Moldagem com colher de pedreiro logo após colocação de água

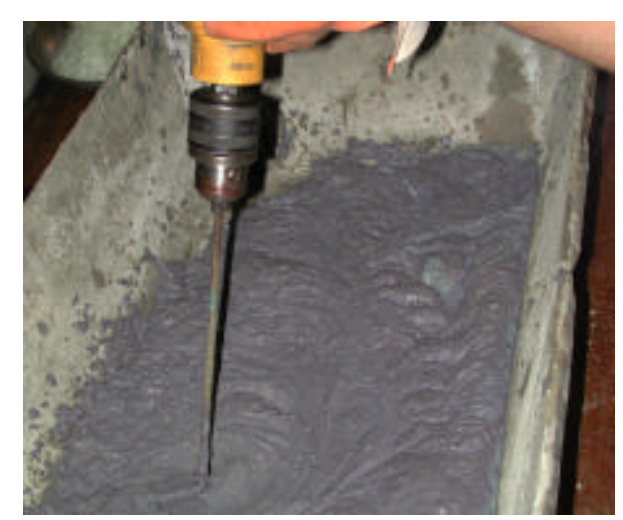

Figura 3.3b - Moldagem utilizando máquina para facilitar a mistura 


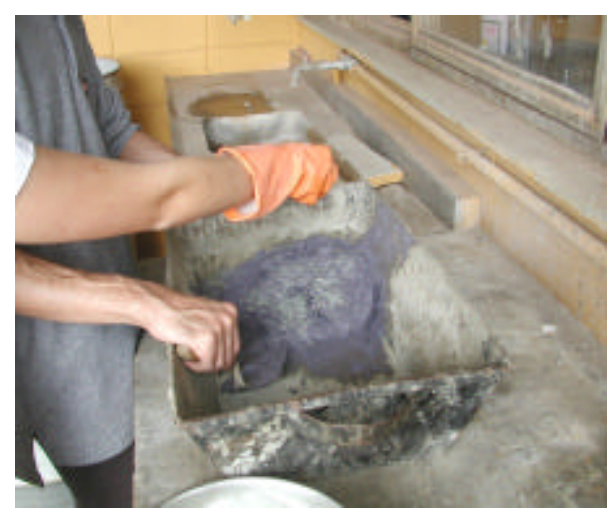

Figura 3.3c - Aplicação de fibra à mistura, após colocação de cimento, areia, vermiculita, látex e água, nesta seqüência

Os traços citados anteriormente podem ser observados na Tabela 3.8, na qual também se pode notar que a quantidade de látex varia entre $0 \%, 20 \%, 30 \%$ e $40 \%$, sendo que a maior parte dos traços é moldada com $30 \%$ de látex. A variação de vermiculita oscila entre $0 \%, 5 \%, 10 \%, 25 \%$ e $50 \%$, sendo que a maior parte das misturas é efetuada com pequena quantidade de vermiculita, ou seja, $5 \%$ ou mistura sem o material. Já a variação da quantidade de fibra está entre $0 \%, 1 \%, 2 \%, 3 \%$ e 4\%, sendo que a quantidade de $3 \%$ é a mais utilizada para a fibra de PVA e a quantidade de $2 \%$ é a mais utilizada para a de vidro.

As misturas destacadas são as que foram moldadas e ensaiadas para a determinação das características do compósito em estudo. Também se deve destacar que foram ensaiados 4 traços substituindo a fibra de PVA por fibra de vidro para comparação dos resultados, em razão da última possuir características de dimensão e atribuição de resistência aos corpos similar à primeira e, ainda, poder ser encontrada com maior facilidade no mercado. Ressalta-se, também, que a substituição não se deu apenas no tipo de fibra empregada, mas nas maiores quantidades de vermiculita, visando obter um compósito de menor dureza, como se poderá observar posteriormente, no capítulo de apresentação e análise dos resultados.

Também foi realizada a substituição da fibra de PVA pela de polipropileno, apenas para um traço, pois a trabalhabilidade era bastante prejudicada em razão do comprimento deste tipo de fibra. 
Tabela 3.8 - Misturas para ensaios de caracterização do material

\begin{tabular}{|c|c|c|}
\hline $\begin{array}{c}\text { Consumo de } \\
\text { Vermiculita } \\
(\text { em \%) }\end{array}$ & $\begin{array}{c}\text { Taxa } \\
\text { volumétrica de } \\
\text { Látex }(\mathrm{em} \%)\end{array}$ & $\begin{array}{l}\text { Taxa volumétrica de } \\
\text { fibra de PVA (em \%) }\end{array}$ \\
\hline 25 & 30 & 3 \\
\hline 25 & 30 & 2 \\
\hline 10 & 30 & 3 \\
\hline 5 & 30 & 3 \\
\hline 0 & 30 & 3 \\
\hline 5 & 0 & 3 \\
\hline 5 & 20 & 2 \\
\hline 5 & 40 & 3 \\
\hline 5 & 30 & 0 \\
\hline 5 & 30 & 1 \\
\hline 5 & 30 & 2 \\
\hline 5 & 30 & 4 \\
\hline 0 & 30 & 2 \\
\hline 0 & 30 & 4 \\
\hline 0 & 40 & 2 \\
\hline 0 & 0 & 0 \\
\hline $\begin{array}{c}\text { Consumo de } \\
\text { Vermiculita } \\
(\text { em \%) }\end{array}$ & $\begin{array}{c}\text { Taxa } \\
\text { volumétrica de } \\
\text { Látex }(\mathrm{em} \%)\end{array}$ & $\begin{array}{l}\text { Taxa volumétrica de } \\
\text { fibra de vidro (em \%) }\end{array}$ \\
\hline 50 & 30 & 2 \\
\hline 25 & 30 & 2 \\
\hline 5 & 30 & 2 \\
\hline 5 & 30 & 3 \\
\hline $\begin{array}{c}\text { Consumo de } \\
\text { Vermiculita } \\
(\text { em \%) }\end{array}$ & $\begin{array}{c}\text { Taxa } \\
\text { volumétrica de } \\
\text { Látex }(\mathrm{em} \%)\end{array}$ & $\begin{array}{c}\text { Taxa volumétrica de } \\
\text { fibra de polipropileno } \\
(\mathrm{em} \%)\end{array}$ \\
\hline 5 & 30 & 2 \\
\hline
\end{tabular}

\subsubsection{Resistência à compressão}

O ensaio em questão tem por objetivo avaliar a resistência à compressão axial de corpos-de-prova mediante aplicação direta de carga numa área circular de $5 \mathrm{~cm}$ de diâmetro. Para aplicação da carga e controle de sua efetuação, utiliza-se uma máquina 
presente no Laboratório de Estruturas, a Versatester 30M, para aplicação da carga, controle da velocidade de sua aplicação e realização do ensaio pertinente.

Para que os corpos possam ser ensaiados após 7 dias de sua moldagem, eles devem ser capeados ou retificados, para que haja uma aplicação de carga mais uniforme por toda a região de aplicação da mesma. Optourse pelo capeamento dos corpos com enxofre. Nas Figuras 3.4a e 3.4b, pode-se visualizar, respectivamente, o corpo-de-prova já capeado, pronto para o ensaio, e o esquema de ensaio (sua ṅstalação na prensa hidráulica) para obtenção da resistência média à compressão de 4 corpos-de-prova.

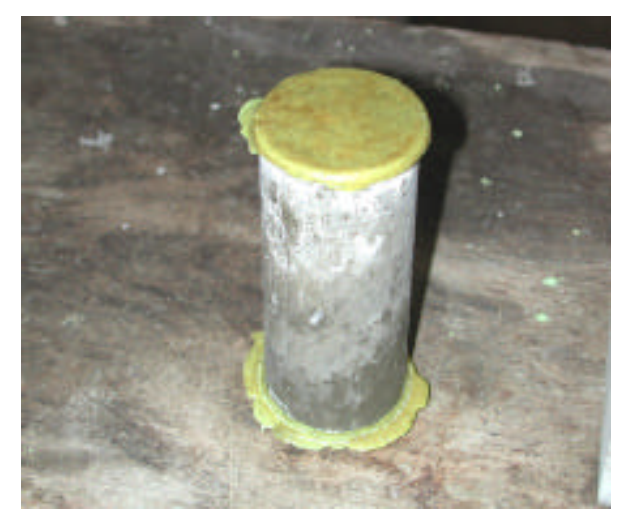

Figura 3.4a - Corpo-de-prova após capeamento para ser ensaiado

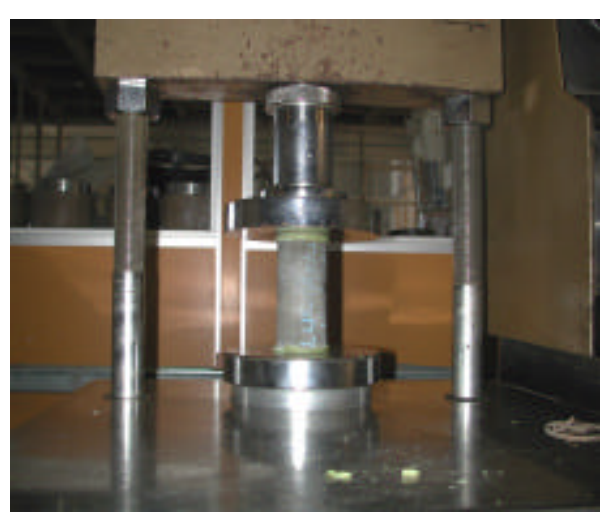

Figura 3.4b - Esquema do ensaio de compressão axial

Neste ensaio basta aplicar a carga controlando a velocidade de aplicação da máquina até o ponto em que a mesma não pode mais ser aplicada, ponto este que simboliza a força máxima.

Calcula-se a tensão máxima para cada traço e constróise gráfico para melhor comparação dos resultados.

Os valores das resistências médias à compressão dos 4 corpos-de-prova foram calculados de acordo com a NBR 7215/1982.

Sendo assim, a tensão de ruptura dos corpos-de-prova era determinada de acordo com a expressão:

$$
\mathrm{f}_{\mathrm{cj}}=\frac{\mathrm{N}}{\mathrm{A}}
$$


Onde:

$\mathrm{f}_{\mathrm{cj}}$ : resistência à compressão do compósito aos j dias de idade

$\mathrm{N}$ : carga de ruptura

A: área da seção do corpo-de-prova

O exemplo do cálculo de um traço específico bem como seus resultados serão apresentados no capítulo de resultados e análises.

\subsubsection{Resistência à tração por compressão diametral}

Este ensaio tem por objetivo avaliar a resistência à tração, por compressão diametral de corpos-de-prova, mediante aplicação de uma carga distribuída em torno da altura do cilindro, portanto, $10 \mathrm{~cm}$ de comprimento no qual a carga é aplicada. Para aplicação da carga e controle de sua efetuação também se utilizava a Versatester 30M, para aplicação da carga, controle da velocidade de sua aplicação e realização do ensaio pertinente.

Este tipo de ensaio foi realizado para determinação da máxima resistência à tração de 4 corpos-de-prova cilíndricos e, para tal, utilizava-se o dispositivo metálico mostrado na Figura 3.5.

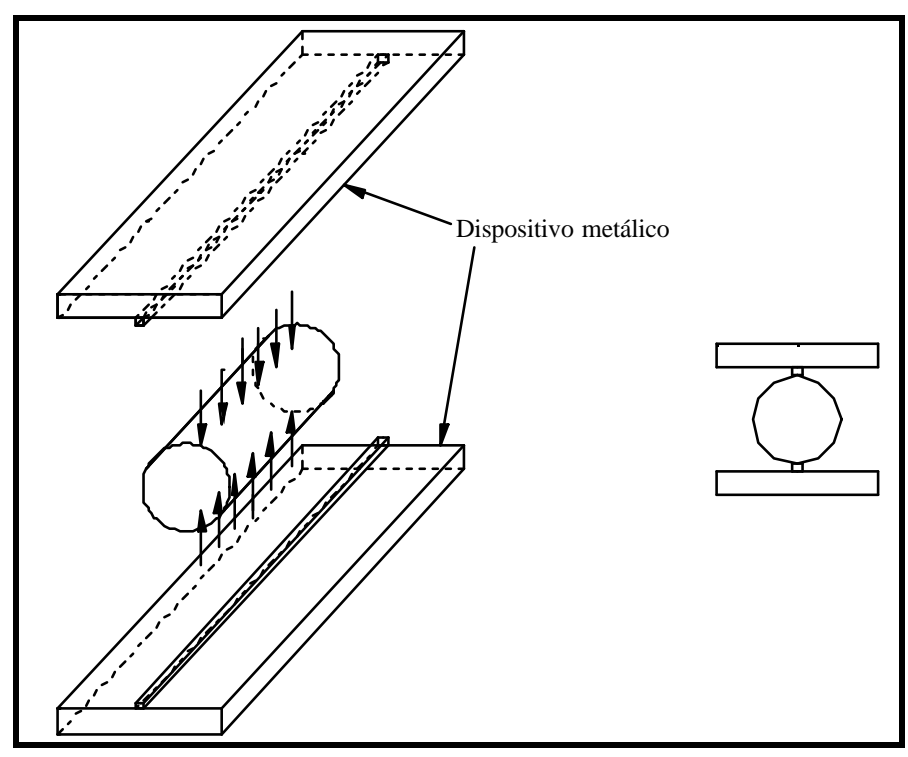

Figura 3.5 - Dispositivo metálico para a realização dos ensaios de tração por compressão diametral 
Para melhor visualização do modelo do ensaio, já na máquina, pode-se observar as Figuras 3.6a e 3.6b, nas quais se pode ver por dois ângulos distintos, o ensaio de compressão diametral. Nestas figuras o ensaio está sendo efetuado em corpo-de-prova com traço V5L30F3.

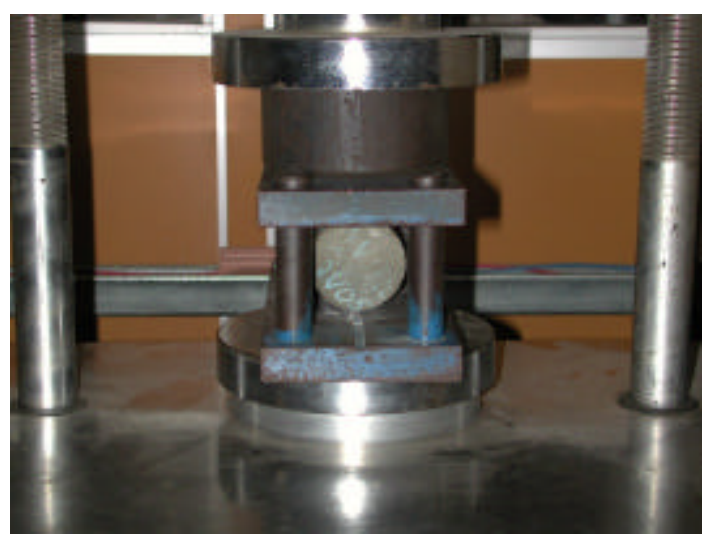

Figura 3.6a - Ensaio de tração por compressão diametral (a)

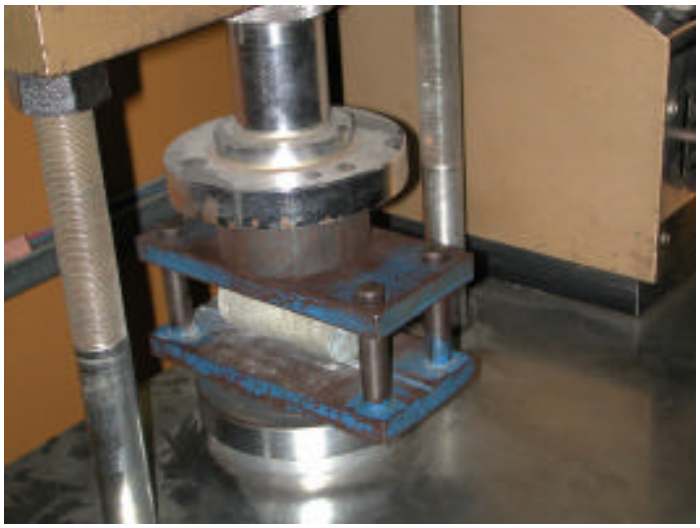

Figura 3.6b - Ensaio de tração por compressão diametral (b)

Neste ensaio, basta aplicar a carga controlando a velocidade de aplicação da máquina até o ponto em que a mesma não pode mais ser aplicada, ponto este que simboliza a força máxima que pode ser aplicada, sendo que em alguns casos, dependendo do traço, o corpo-de-prova sofre pequenas ou grandes fissuras ou nem mesmo chega a se romper mediante a carga máxima tolerável, como poderá ser observado no capítulo de resultados e análises.

Após a aplicação de carga nos corpos-de-prova utilizando-se o dispositivo mostrado nas Figuras 3.5, 3.6a e 3.6b, utilizam-se planilhas de cálculo e calcula-se a tensão máxima de tração para cada traço. Na seqüência, constrói-se gráfico para melhor comparação dos resultados. No capítulo de resultados e análises será apresentado o cálculo completo de um traço específico, bem como os resultados e comparações.

Os valores das resistências médias à tração dos 4 corpos-de-prova foram calculados de acordo com a NBR 7222/1983.

A tensão de compressão gera uma tensão de tração transversal uniforme ao longo do diâmetro, e cada elemento, submetido a um estado duplo de tensões, não romperá por compressão, mas por uma tração de valor: 


$$
f_{c t, s p}=\frac{2 F}{\pi \cdot d \cdot h} \cdot 0,85
$$

Onde:

$\mathrm{F}_{\mathrm{ctspp}}:$ resistência à tração por compressão diametral

F: força máxima aplicada

h: comprimento do corpo-de-prova

d: diâmetro do corpo-de-prova

\subsubsection{Módulo de elasticidade}

Este ensaio tem por objetivo a obtenção do módulo de elasticidade por meio de aplicação de carga axialmente ao corpo-de-prova. A aplicação se dá numa área circular de $5 \mathrm{~cm}$ de diâmetro e utilizam-se dois transdutores com haste de $50 \mathrm{~mm}$, colocados em lados opostos do corpo-de-prova a ser ensaiado, aproximadamente a $25 \mathrm{~mm}$ da base do corpo de $100 \mathrm{~mm}$ de altura, sendo que esses transdutores ficam ligados a um aparelho de aquisição dos valores de deslocamento, os quais são lidos aos poucos enquanto a carga vai sendo aplicada paulatinamente. Na verdade, a leitura de deslocamento no aparelho era realizada a cada $2,5 \mathrm{kN}$, sendo assim, tem-se carga e deslocamento e, a partir dessas grandezas, obtêm-se os valores de tensão e deformação, respectivamente.

Nas Figuras 3.7, 3.8a e 3.8b, pode-se verificar o corpo já capeado como no caso do ensaio de compressão axial, pronto para o ensaio, e o dispositivo de ensaio, respectivamente.

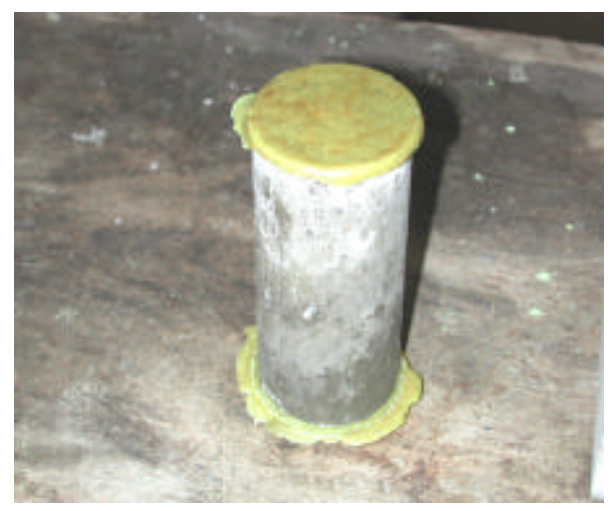

Figura 3.7 - Corpo-de-prova após capeamento para ser ensaiado 


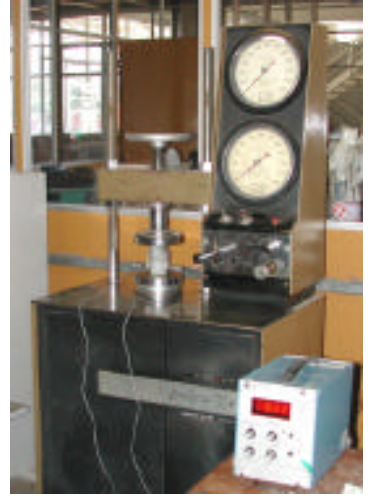

Figura 3.8a - Ensaio para obtenção do módulo de elasticidade (a)

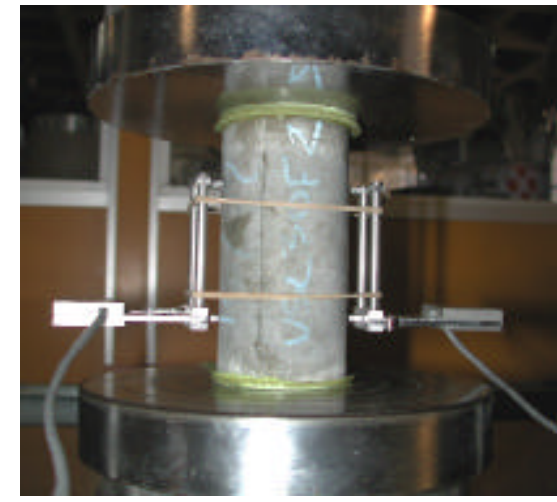

Figura 3.8b - Ensaio para obtenção do módulo de elasticidade (b)

Neste ensaio, basta aplicar a carga, controlando a velocidade de aplicação da máquina até uma certa carga, um pouco inferior à carga de ruptura dos corpos-de-prova à compressão axial, a fim de não danificar os transdutores. Sendo assim, o gráfico representado na Figura 3.9 é justificado, já que, na verdade, aquela curva deveria continuar de forma que para menores valores de tensão (após o pico de tensão) se obtivessem maiores deformações.

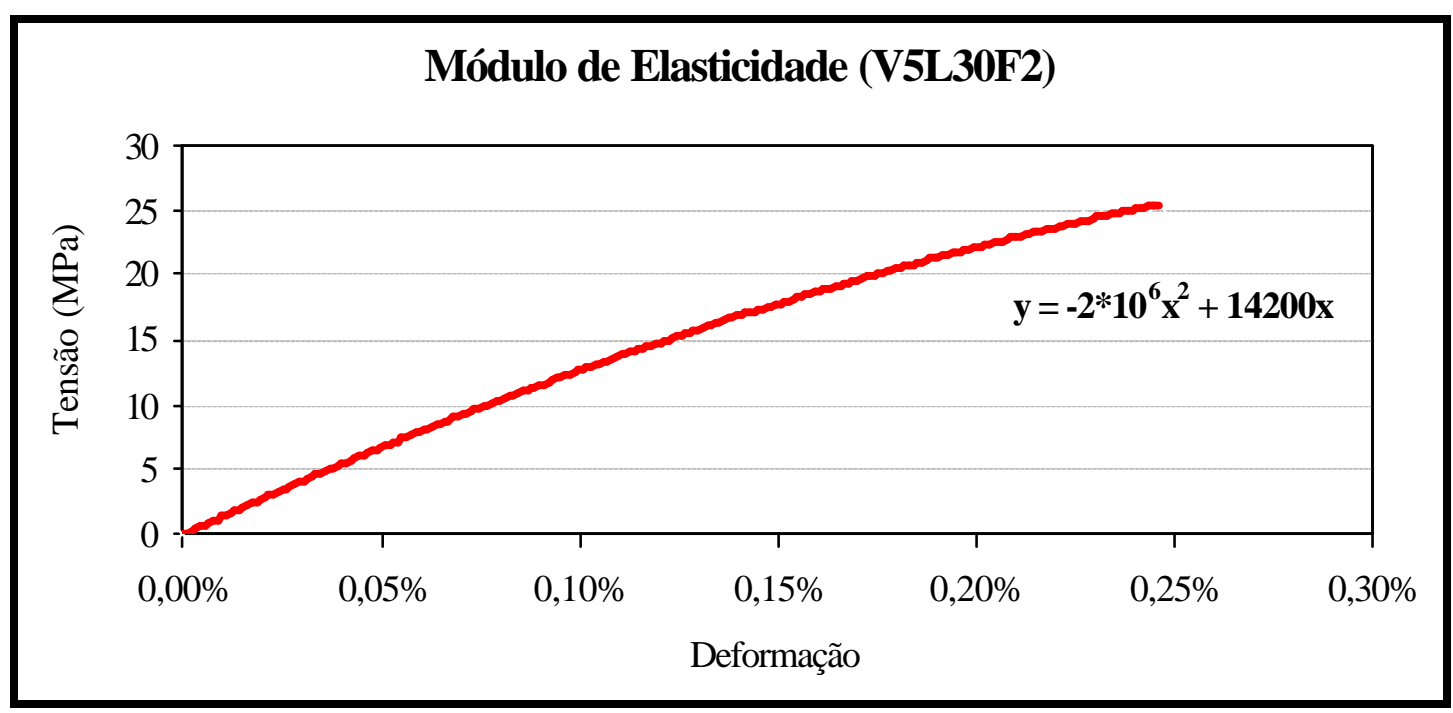

Figura 3.9 - Gráfico para determinação do Módulo de Elasticidade

Na Figura 3.9, pode-se observar um gráfico, no qual é mostrada uma curva Tensão x Deformação de um determinado traço (no caso, V5L30F2), bem como a curva 
da regressão para aproximação dos valores desta curva com aqueles que compõem uma equação de $2^{\circ}$ grau, da qual se adota um determinado ponto e se obtém o módulo de elasticidade tangente da mistura.

No caso da Figura 3.9, tem-se o traço V5L30F2 e para o mesmo tem-se um módulo de elasticidade tangente igual a $14200 \mathrm{MPa}$, ou seja, o valor correspondente à variável $b$ de uma equação de $2^{\circ}$ grau. O procedimento descrito anteriormente é repetido para os demais traços. A partir da curva representativa de Tensão x Deformação e da curva da equação (regressão) pode-se obter também o módulo de elasticidade secante. Isso é feito adotando-se um valor que corresponde a, aproximadamente, 50\% do valor da tensão de ruptura dos corpos-de-prova do referido traço, sendo que este valor deve coincidir nas duas curvas. Pega-se, no eixo horizontal, o valor da deformação correspondente à referida tensão e, a partir da razão entre as referidas tensão e deformação, obtém-se o valor do módulo de elasticidade secante da mistura.

Para se verificar a consistência dos resultados obtidos com o procedimento adotado (transdutores) para a obtenção do módulo de elasticidade, resolveu-se fazer ensaios em um traço específico com a utilização de extensômetro acoplado ao corpo-deprova e, a seguir, repetindo-se o procedimento até o momento relatado para outros corpos-de-prova de mesmo traço, traço esse que foi chamado de traço de referência, VOLOF0, no qual não havia vermiculita, látex ou fibras. Nas Figuras 3.10a e 3.10b, pode-se verificar as duas formas de ensaio.

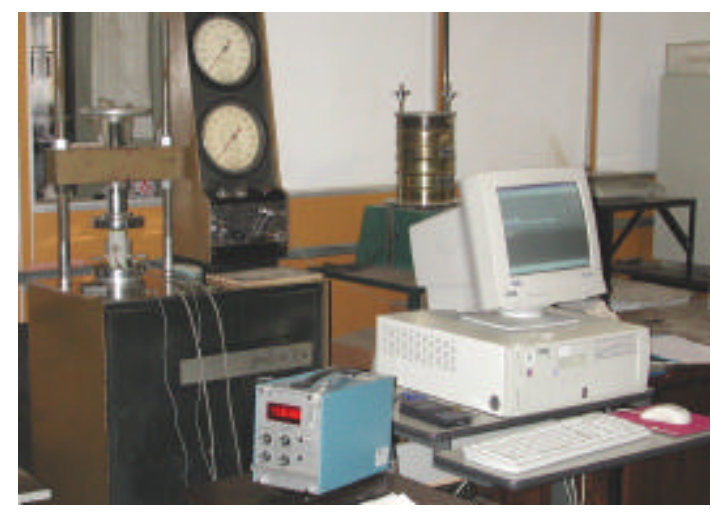

Figura 3.10a - Ensaio para obtenção do módulo de elasticidade em corpos-de-prova por meio de transdutores e extensômetro (a)

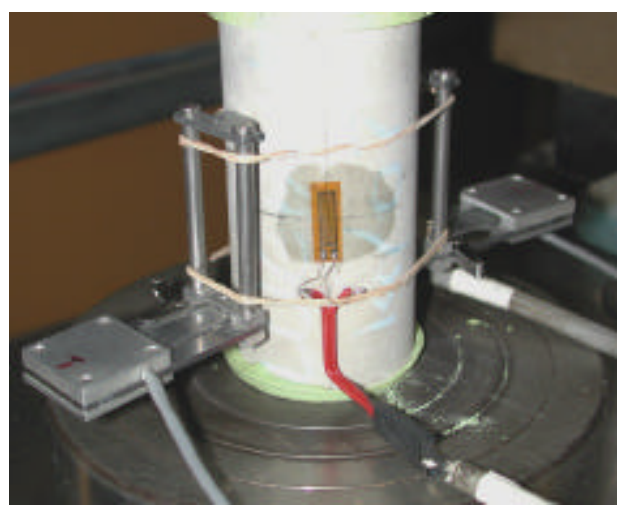

Figura 3.10b - Ensaio para obtenção do módulo de elasticidade em corpos-deprova por meio de transdutores e extensômetro (b) 


\subsubsection{Depuração estatística dos resultados}

A depuração dos resultados de resistência à compressão e tração por compressão diametral, bem como daqueles obtidos para o módulo de elasticidade, foi realizada pelo critério de Chauvenet, no qual, para uma série de medidas, a probabilidade de ocorrência de um desvio de valor " $x$ " é menor que $1 / 2 n$, onde $n$ corresponde ao número de medidas (TAKEYA, 2001).

\subsection{Ensaios de placas}

Neste capítulo, serão abordadas algumas características de almofadas do compósito: rigidez por meio de ensaio de carga uniforme e ensaio de carga pontual.

O capítulo, então, será dividido em três partes distintas: preparação das placas, ensaios de compressão e ensaios de afundamento.

\subsubsection{Moldagem de placas}

Neste caso, foram moldadas placas de $15 \mathrm{~cm} \times 15 \mathrm{~cm}$ de área da base, com espessuras de 5, 10 e 20mm; também foram moldadas placas com as mesmas espessuras, todavia com área da base definida em $10 \mathrm{~cm} \times 10 \mathrm{~cm}$, destinadas ao ensaio de compressão, para avaliação do efeito de forma durante a aplicação da carga. As placas foram confeccionadas para vários traços distintos e ensaiadas a afundamento e compressão para determinação da rigidez de cada espessura de placa para cada traço diferente.

A moldagem das placas foi realizada no Laboratório de Estruturas da Escola de Engenharia de São Carlos e, para se efetuar a moldagem delas, utilizaram-se os equipamentos e dispositivos específicos existentes no Laboratório de Estruturas.

Na seqüência, são mostradas algumas fotos tiradas durante a moldagem de um traço específico (no caso, V5L30F3), seguidas de fotos do adensamento em mesa vibratória e posterior acabamento com colher de pedreiro ou desempenadeira.

As figuras estão expostas na ordem em que ocorre a moldagem das placas, com posterior adensamento, desmoldagem 1 dia após a moldagem e colocação das placas na 
câmara úmida após a desmoldagem para que seja estabelecida a cura de 7 dias até o ensaio.

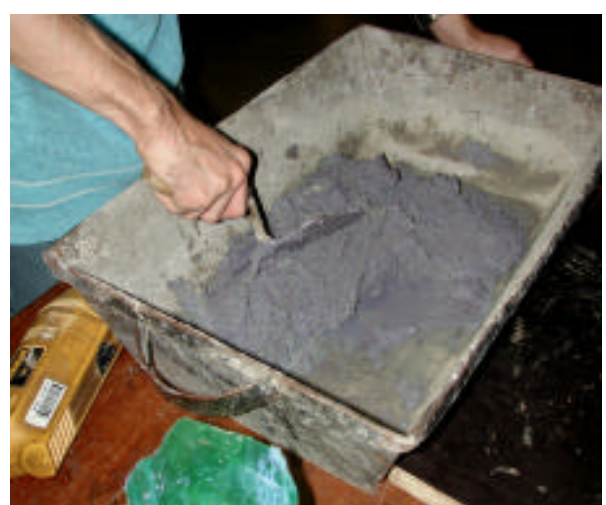

Figura 3.11 - Moldagem com colher de pedreiro logo após colocação de água

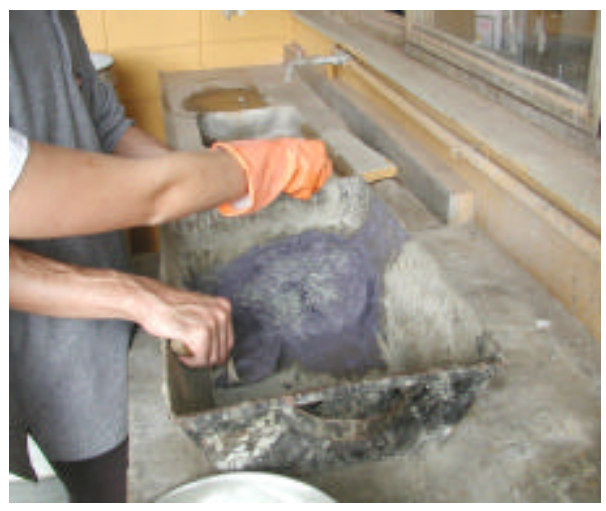

Figura 3.13 - Aplicação de fibra de PVA à mistura, após colocação de cimento, areia, vermiculita, látex e água, respectivamente

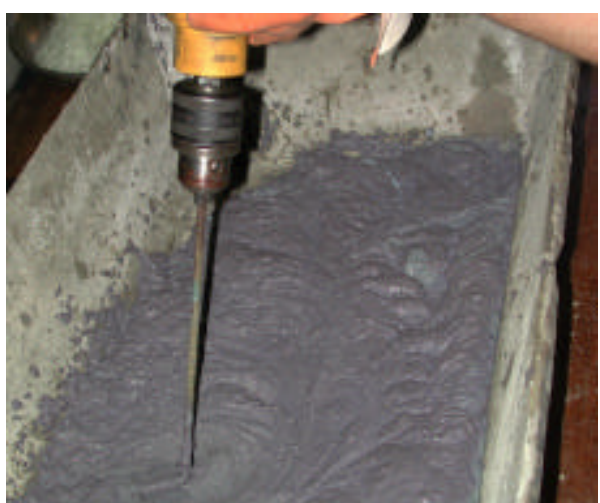

Figura 3.12 - Moldagem utilizando máquina para facilitar a mistura

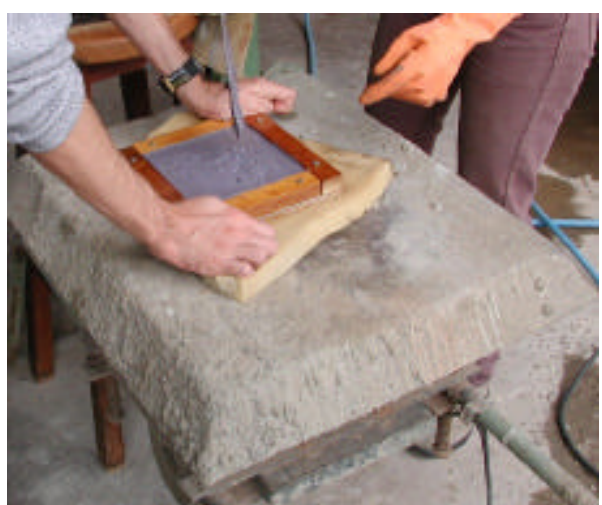

Figura 3.14 - Adensamento em mesa vibratória, após aplicação da fibra de PVA 


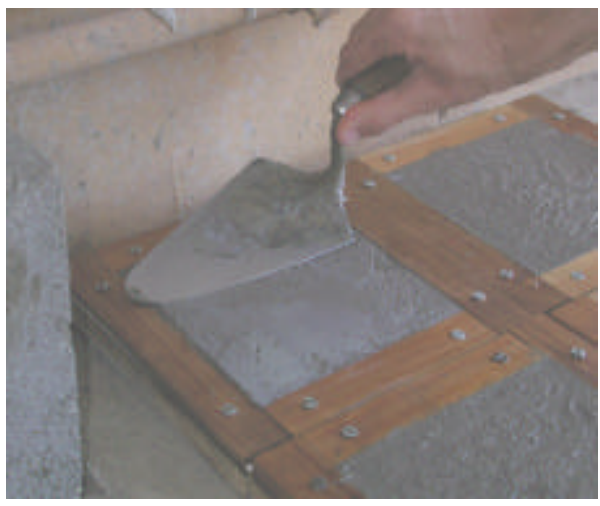

Figura 3.15 - Acabamento com colher de pedreiro embebida em água após adensamento

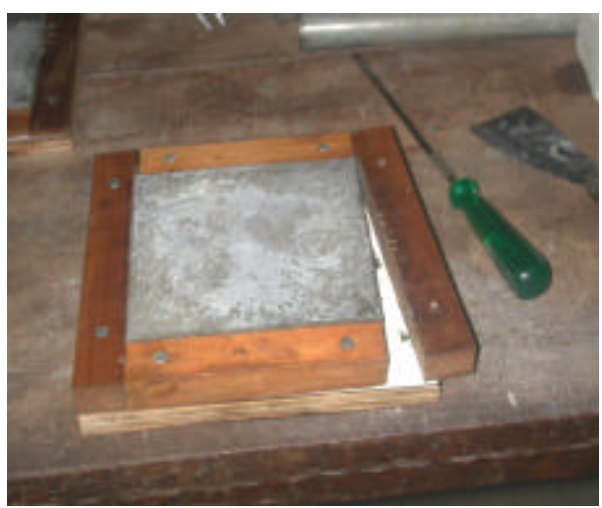

Figura 3.17 - Desmoldagem 1 dia após a moldagem

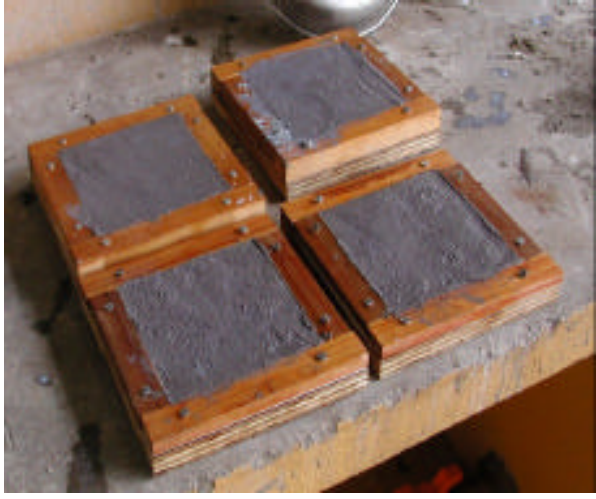

Figura 3.16 - Placas em sua composição final, após acabamento

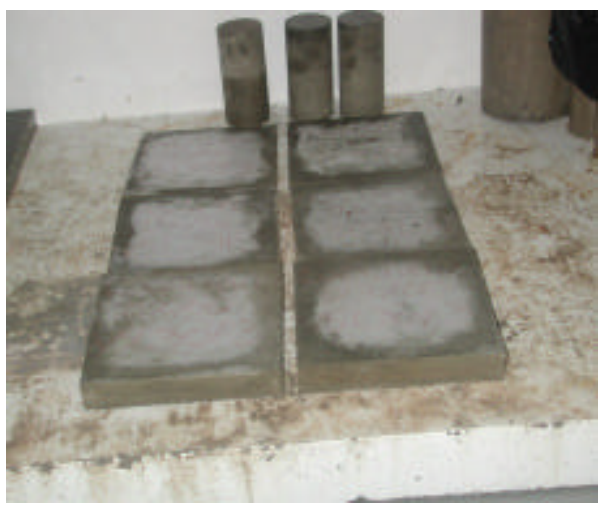

Figura 3.18 - Colocação das placas desmoldadas na câmara úmida para aguardar a cura de 7 dias

A seguir, o sub-capítulo é dividido em duas partes, sendo que a primeira delas trata dos ensaios de rigidez e a subseqüente relata os ensaios de afundamento, incluindo os traços que foram moldados para os dois tipos de ensaios.

\subsubsection{Ensaio de carga uniforme}

O ensaio de carga uniforme (compressão) foi realizado em almofadas do compósito com o intuito de se obter a rigidez de placa, que corresponde à capacidade da placa se deformar (sem se romper) e que pode ser representada pela equação 3.11 . 


$$
\mathrm{R}=\frac{\sigma}{\frac{\Delta \mathrm{h}}{\mathrm{h}}}
$$

Onde:
$\mathrm{R}$ : rigidez da placa
$\sigma:$ tensão aplicada

$\Delta \mathrm{h}$ : variação da espessura da placa

h: espessura da placa

Tabela 3.9 - Misturas para ensaios de compressão uniforme nas placas de $15 \mathrm{~cm}$ x $15 \mathrm{~cm}$

\begin{tabular}{|c|c|c|}
\hline $\begin{array}{c}\text { Consumo de } \\
\text { Vermiculita } \\
(\text { em \%) }\end{array}$ & $\begin{array}{c}\text { Taxa } \\
\text { volumétrica de } \\
\text { Látex }(\mathrm{em} \%)\end{array}$ & $\begin{array}{l}\text { Taxa volumétrica de } \\
\text { fibra de PVA (em \%) }\end{array}$ \\
\hline 0 & 0 & 0 \\
\hline 0 & 30 & 3 \\
\hline 5 & 30 & 2 \\
\hline 5 & 30 & 3 \\
\hline 5 & 30 & 4 \\
\hline 10 & 30 & 3 \\
\hline 25 & 30 & 2 \\
\hline $\begin{array}{l}\text { Consumo de } \\
\text { Vermiculita } \\
\text { (em \%) }\end{array}$ & $\begin{array}{c}\text { Taxa } \\
\text { volumétrica de } \\
\text { Látex }(\mathrm{em} \%)\end{array}$ & $\begin{array}{l}\text { Taxa volumétrica de } \\
\text { fibra de vidro (em \%) }\end{array}$ \\
\hline 0 & 30 & 3 \\
\hline 5 & 30 & 2 \\
\hline 5 & 30 & 3 \\
\hline 25 & 30 & 2 \\
\hline 50 & 30 & 2 \\
\hline $\begin{array}{c}\text { Consumo de } \\
\text { Vermiculita } \\
(\text { em \%) }\end{array}$ & $\begin{array}{c}\text { Taxa } \\
\text { volumétrica de } \\
\text { Látex }(\mathrm{em} \%)\end{array}$ & $\begin{array}{c}\text { Taxa volumétrica de } \\
\text { fibra de polipropileno } \\
(\mathrm{em} \%)\end{array}$ \\
\hline 5 & 30 & 2 \\
\hline
\end{tabular}


Neste caso, foram moldadas 6 placas de $15 \mathrm{~cm} \times 15 \mathrm{~cm}$ para cada traço, 2 placas de cada uma das espessuras anteriormente especificadas $(5,10$ e 20mm). Para avaliar o efeito de forma, foram moldadas 4 placas, duas delas com $10 \mathrm{~mm}$ de espessura e outras 2 com $20 \mathrm{~mm}$.

Os traços destinados a este tipo de ensaio, destacados no parágrafo anterior, podem ser observados nas Tabelas 3.9 (placas de $15 \mathrm{~cm}$ x $15 \mathrm{~cm}$ ) e 3.10 (placas de $10 \mathrm{~cm}$ $\mathrm{x} 10 \mathrm{~cm}$ ), nas quais também se pode notar que a quantidade de látex varia entre $0 \% \mathrm{e}$ $30 \%$, sendo que a maior parte dos traços é moldada com $30 \%$ de látex. A variação de vermiculita oscila entre $0 \%, 5 \%, 10 \%, 25 \%$ e $50 \%$, sendo que a maior parte das misturas é efetuada com pequena quantidade de vermiculita para as placas maiores, ou seja, $5 \%$ ou mistura sem o material. Já a variação da quantidade de fibra está entre $0 \%$, $2 \%, 3 \%$ e $4 \%$, sendo que a quantidade de $3 \%$ é a mais utilizada para a fibra de PVA e a quantidade de $2 \%$ é a mais utilizada para a de vidro.

Tabela 3.10 - Misturas para ensaios de compressão uniforme nas placas de $10 \mathrm{~cm} \times 10 \mathrm{~cm}$

\begin{tabular}{|c|c|c||}
\hline $\begin{array}{c}\text { Consumo de } \\
\text { Vermiculita } \\
(\text { em \%) }\end{array}$ & $\begin{array}{c}\text { Taxa } \\
\text { volumétrica de } \\
\text { Látex (em \%) }\end{array}$ & $\begin{array}{c}\text { Taxa volumétrica de } \\
\text { fibra de PVA (em \%) }\end{array}$ \\
\hline 0 & 0 & 0 \\
\hline 5 & 30 & 3 \\
\hline 25 & 30 & 2 \\
\hline $\begin{array}{c}\text { Consumo de } \\
\text { Vermiculita } \\
(\text { em \%) }\end{array}$ & $\begin{array}{c}\text { Taxa } \\
\text { Látex (em \%) }\end{array}$ & fibra de vidro (em \%) \\
\hline 25 & 30 & 2 \\
\hline 50 & 30 & 2 \\
\hline
\end{tabular}

As misturas destacadas nas Tabelas 3.9 e 3.10 são as que foram moldadas e ensaiadas para a determinação das características do compósito em estudo.

Além desses traços especificados para o compósito, também foram realizados ensaios de compressão em placas de madeira de $15 \mathrm{~cm}$ x $15 \mathrm{~cm}$ e de $10 \mathrm{~cm}$ x $10 \mathrm{~cm}$ (Pinus Taeda e Eucalipto Citriodora, citados na parte de materiais deste capítulo) para as espessuras de $10 \mathrm{~mm}$ e $20 \mathrm{~mm}$ e almofadas de neoprene de $10 \mathrm{~cm}$ x $10 \mathrm{~cm}$ e espessura de 
$10 \mathrm{~mm}$ e $20 \mathrm{~mm}, 2$ almofadas para cada espessura tanto das madeiras quanto do neoprene.

Os ensaios de carga uniforme para determinação da rigidez foram executados em uma Máquina Instron (Figuras 3.19a, 3.19b e 3.19c) do Laboratório de Estruturas, sendo que inicialmente as placas foram submetidas a uma carga, a qual era implementada gradualmente e a uma velocidade de $5 \mathrm{kN} / \mathrm{s}$ até atingir uma determinada carga em que a almofada tivesse uma deformação de, no máximo, 60\%, para, então, determinar graficamente a rigidez da placa.

Sendo assim, foram necessários diversos recursos disponíveis no Laboratório de Estruturas, dentre eles: máquina Instron, sistema de aquisição de dados com a utilização de transdutores e de computador para alocar os valores de carga e deslocamento em planilhas e construção dos gráficos, além do carregamento imposto pela máquina Instron, como mostrado na Figura 3.19c.

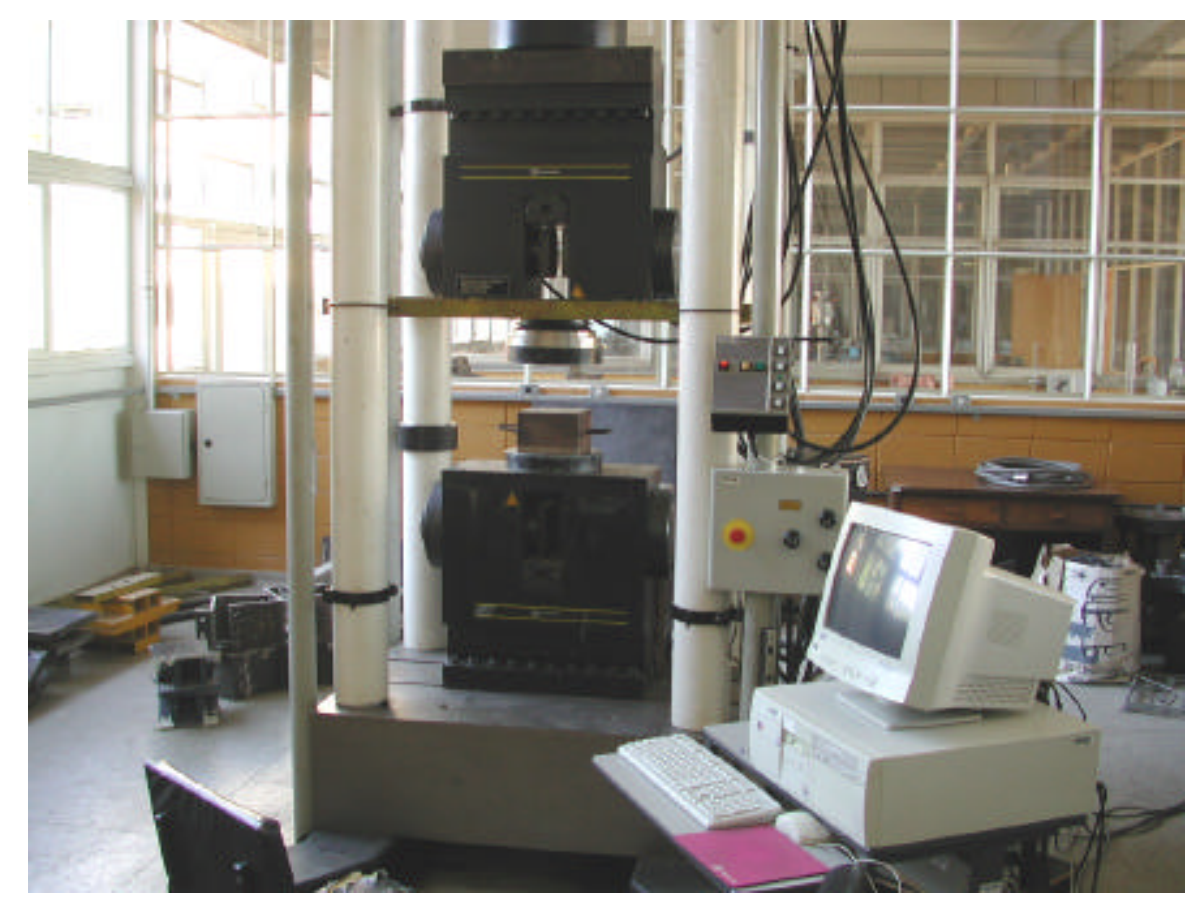

Figura 3.19a - Máquina Instron (sistema para aplicação de carga) 


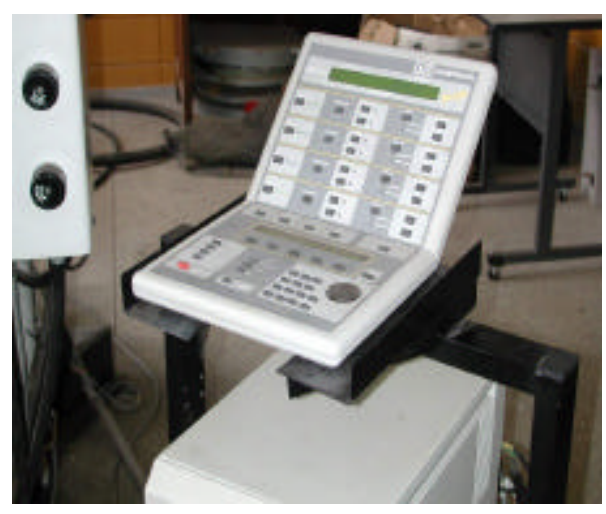

Figura 3.19b - Sistema de controle de velocidade e aplicação

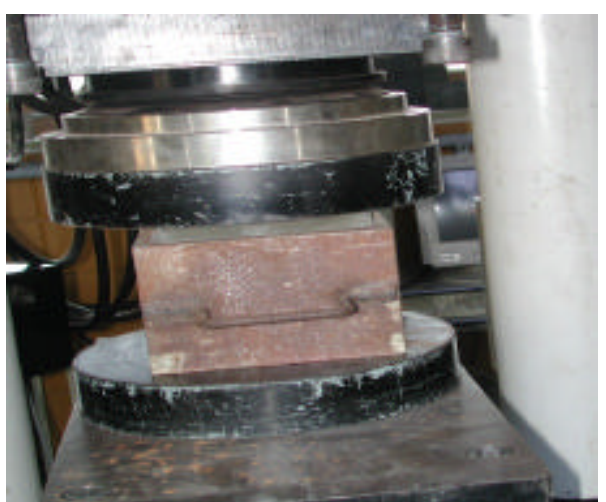

Figura 3.19c - Aplicação de carga em placa de $15 \mathrm{~cm} \times 15 \mathrm{~cm}$

Realizados os ensaios, os resultados ficavam alocados em planilhas, com extensão CSV. São alocadas duas colunas, as quais representam, respectivamente, carga e deslocamento do pistão e, a partir dessas duas colunas, obtém-se, respectivamente, tensão (eq. 3.12) e deformação (eq. 3.13), utilizando-se a área da base das placas e a espessura destas para os cálculos serem efetuados.

$$
\sigma_{n}=\frac{F_{n}}{A}
$$

Onde:

$\sigma_{\mathrm{n}}:$ tensão de um determinado ponto (MPa)

$\mathrm{F}_{\mathrm{n}}$ : força de um determinado ponto $(\mathrm{kN})$

A: área da placa $\left(\mathrm{cm}^{2}\right)$

$$
\varepsilon_{\mathrm{n}}=\frac{\Delta \mathrm{e}_{\mathrm{n}}}{\mathrm{e}}
$$

Onde:

$\varepsilon_{\mathrm{n}}$ : deformação de um determinado ponto $(\mathrm{mm} / \mathrm{mm})$

$\Delta \mathrm{e}_{\mathrm{n}}:$ deslocamento de um determinado ponto $(\mathrm{mm})$

e: espessura da placa $(\mathrm{mm})$

Feito isso, constrói-se um gráfico de Tensão por Deformação e obtém-se uma curva. Junto à curva, traça-se uma reta que passe por uma grande quantidade de pontos, a partir do ponto em que a variação da curva se aproxima de uma reta, ou seja, a reta é 
traçada a partir do momento em que já ocorreu a acomodação da almofada em razão de suas imperfeições. Traçada a reta, avalia-se seu coeficiente angular, de forma que este representa a rigidez da placa (eq. 3.14), nome este que foi dado pelo pesquisador à grandeza.

$$
\mathrm{R}=\frac{\Delta \sigma_{\mathrm{n}}}{\Delta \varepsilon_{\mathrm{n}}}=\frac{\sigma_{\mathrm{n}_{2}}-\sigma_{\mathrm{n}_{1}}}{\varepsilon_{\mathrm{n}_{2}}-\varepsilon_{\mathrm{n}_{1}}}
$$

Onde:

$\mathrm{R}$ : rigidez da placa $(\mathrm{MPa})$

$\sigma_{\mathrm{n} 2}:$ tensão em um ponto superior da reta $(\mathrm{MPa})$

$\sigma_{\mathrm{n} 1}:$ tensão em um ponto inferior da reta $(\mathrm{MPa})$

$\varepsilon_{\mathrm{n} 2}:$ deformação em ponto superior da reta $(\mathrm{mm} / \mathrm{mm})$

$\varepsilon_{\mathrm{n} 1}$ : deformação em ponto inferior da reta $(\mathrm{mm} / \mathrm{mm})$

Nas Figuras 3.20 e 3.21, pode-se verificar gráfico de Tensão x Deformação e a reta que mostra a rigidez para um dos traços e espessura ensaiados. Corresponde a um traço com 5\% de vermiculita, 30\% de látex e 3\% de fibra de PVA em que a aplicação da carga se deu até $2000 \mathrm{kN}$.

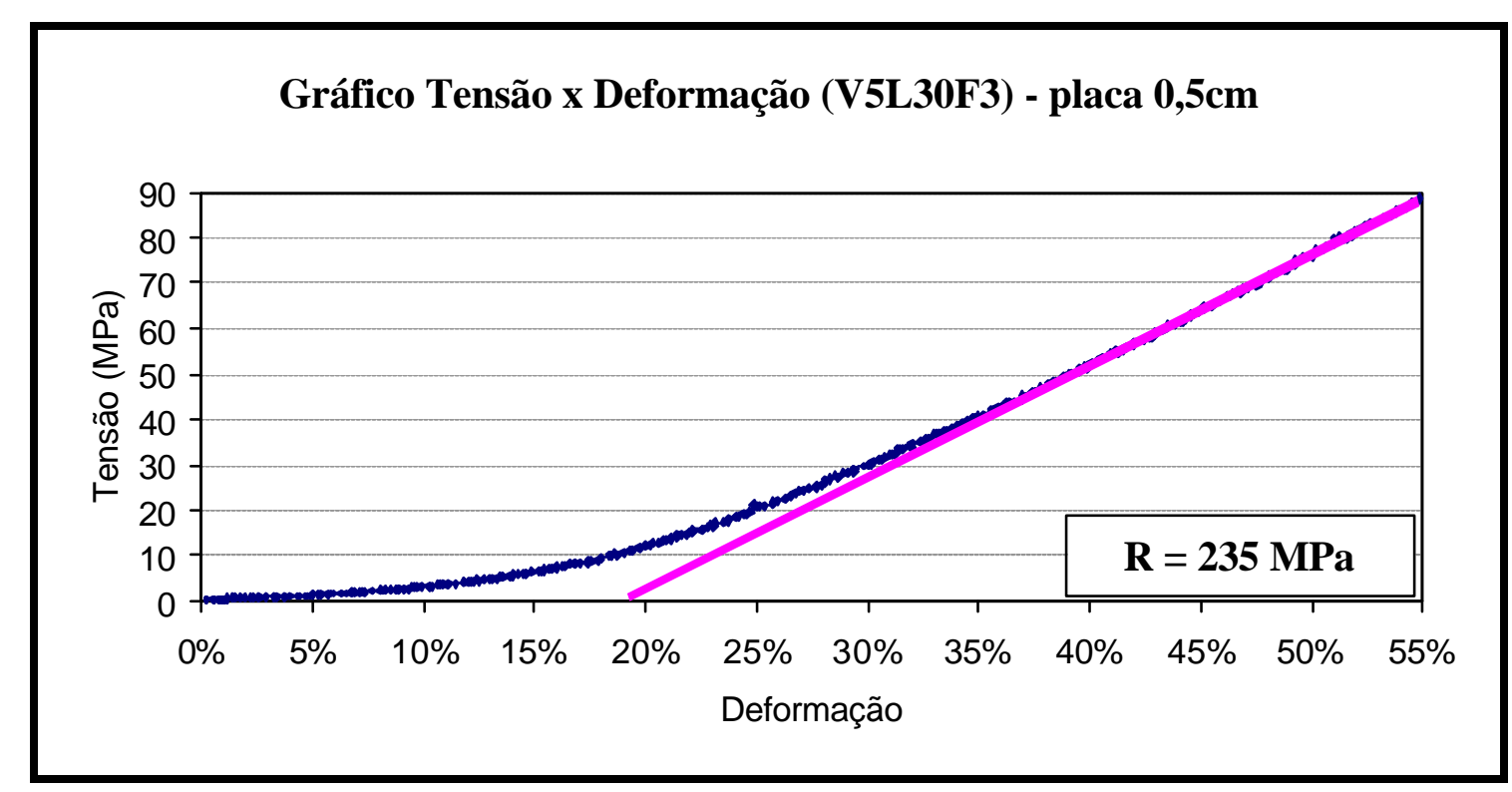

Figura 3.20 - Gráfico Tensão x Deformação para a mistura V5L30F3 $(\mathrm{e}=5 \mathrm{~mm})-1^{\mathrm{a}}$ amostra 


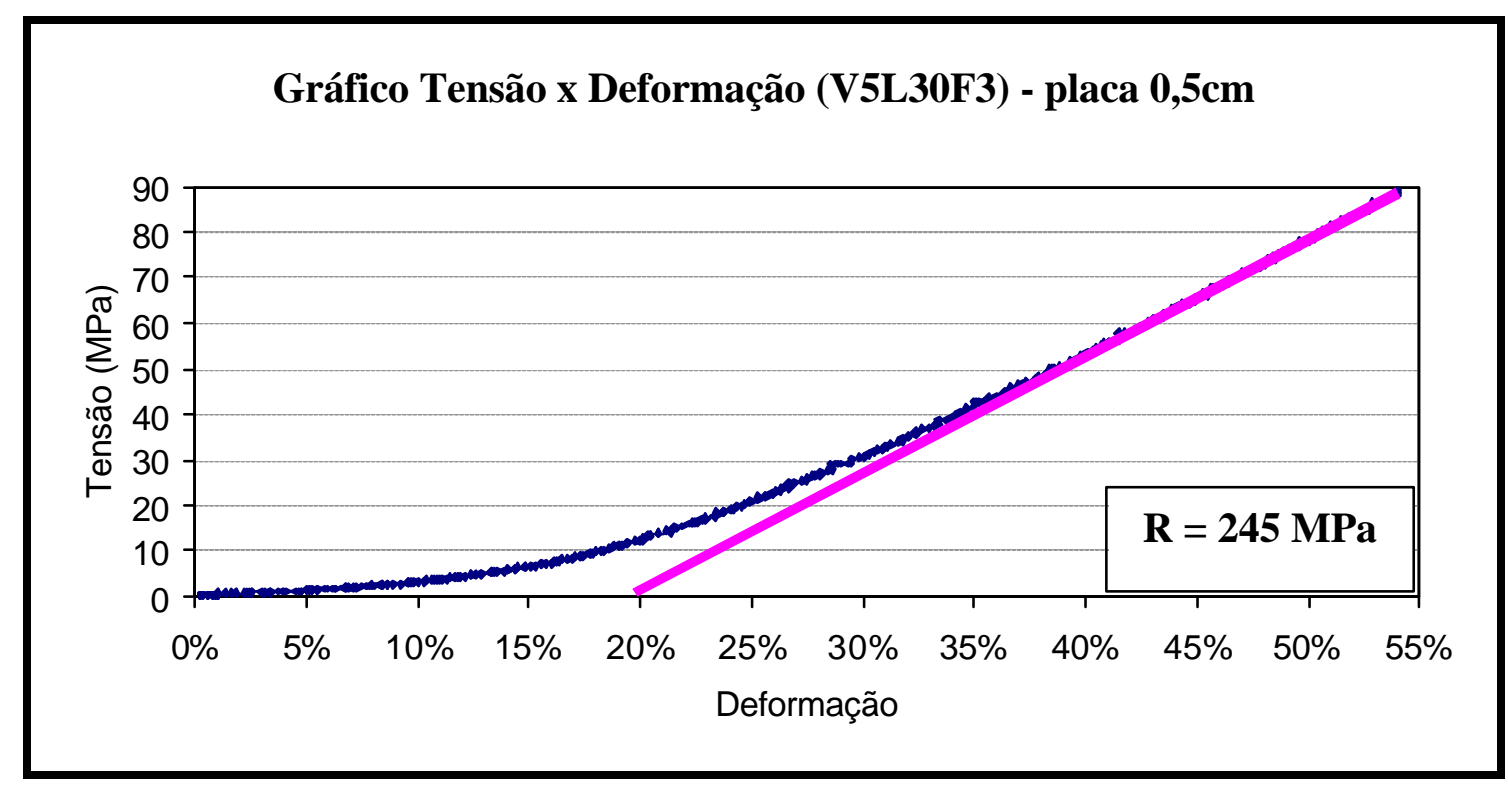

Figura 3.21 - Gráfico Tensão x Deformação para a mistura V5L30F3 $(\mathrm{e}=5 \mathrm{~mm})-2^{\mathrm{a}}$ amostra

Como são ensaiadas duas placas de cada espessura para cada um dos traços especificados, tira-se uma média entre os dois valores e obtém-se a rigidez das placas referentes a cada espessura e cada traço. No caso das Figuras 3.20 e 3.21 (V5L30F3), tem-se uma rigidez de 240MPa para placas de espessura $5 \mathrm{~mm}$.

\subsubsection{Ensaio de carga localizada}

Este ensaio era realizado para medir o afundamento das almofadas. O afundamento da placa pode ser definido como a capacidade de acomodar imperfeições por parte das almofadas do compósito, mediante a aplicação de carga pontual.

Neste caso, foram moldadas 6 placas de $15 \mathrm{~cm}$ x $15 \mathrm{~cm}$ para cada traço, 2 placas de cada uma das espessuras anteriormente especificadas $(5,10$ e $20 \mathrm{~mm})$.

Os traços destinados a este tipo de ensaio, destacados no parágrafo anterior, podem ser visualizados na Tabela 3.11, na qual também se pode notar que a quantidade de látex varia entre $0 \%$ e $30 \%$, sendo que a maior parte dos traços é moldada com $30 \%$ de látex. 
Tabela 3.11 - Misturas para ensaios de carga localizada nas placas de $15 \mathrm{~cm}$ x $15 \mathrm{~cm}$

\begin{tabular}{|c|c|c|}
\hline $\begin{array}{c}\text { Consumo de } \\
\text { Vermiculita } \\
(\text { em \%) }\end{array}$ & $\begin{array}{c}\text { Taxa } \\
\text { volumétrica de } \\
\text { Látex }(\mathrm{em} \%)\end{array}$ & $\begin{array}{l}\text { Taxa volumétrica de } \\
\text { fibra de PVA (em \%) }\end{array}$ \\
\hline 0 & 0 & 0 \\
\hline 0 & 30 & 3 \\
\hline 5 & 30 & 2 \\
\hline 5 & 30 & 3 \\
\hline 5 & 30 & 4 \\
\hline 10 & 30 & 3 \\
\hline 25 & 30 & 2 \\
\hline $\begin{array}{c}\text { Consumo de } \\
\text { Vermiculita } \\
(\text { em \%) }\end{array}$ & $\begin{array}{c}\text { Taxa } \\
\text { volumétrica de } \\
\text { Látex (em \%) }\end{array}$ & $\begin{array}{l}\text { Taxa volumétrica de } \\
\text { fibra de vidro (em \%) }\end{array}$ \\
\hline 5 & 30 & 2 \\
\hline 25 & 30 & 2 \\
\hline 50 & 30 & 2 \\
\hline $\begin{array}{c}\text { Consumo de } \\
\text { Vermiculita } \\
(\text { em \%) }\end{array}$ & $\begin{array}{c}\text { Taxa } \\
\text { volumétrica de } \\
\text { Látex (em \%) }\end{array}$ & $\begin{array}{c}\text { Taxa volumétrica de } \\
\text { fibra de polipropileno } \\
(\mathrm{em} \%)\end{array}$ \\
\hline 5 & 30 & 2 \\
\hline
\end{tabular}

A variação de vermiculita oscila entre $0 \%, 5 \%, 10 \%, 25 \%$ e $50 \%$, sendo que a maior parte das misturas é efetuada com pequena quantidade de vermiculita, ou seja, 5\% ou mistura sem o material, sobretudo no caso de se utilizar fibra de PVA. Já a variação da quantidade de fibra está entre $0 \%, 2 \%, 3 \%$ e $4 \%$, sendo que a quantidade de $3 \%$ é a mais utilizada para a fibra de PVA e a quantidade de $2 \%$ é a mais utilizada para a de vidro. Com relação à fibra de polipropileno, moldoutse apenas um traço, com 5\% de vermiculita, $30 \%$ de látex e $2 \%$ da referida fibra.

O ensaio em questão tem por objetivo determinar o afundamento nas placas com a utilização de um dispositivo metálico, cuja carga é aplicada de forma pontual em duas linhas da placa, como pode ser visto na Figura 3.22. Para determinar o afundamento utiliza-se, portanto, o dispositivo metálico mostrado na Figura 3.23. 


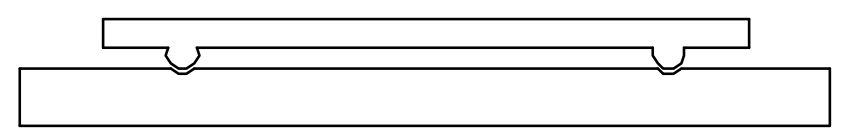

Figura 3.22 - Ensaio de carga localizada em placas

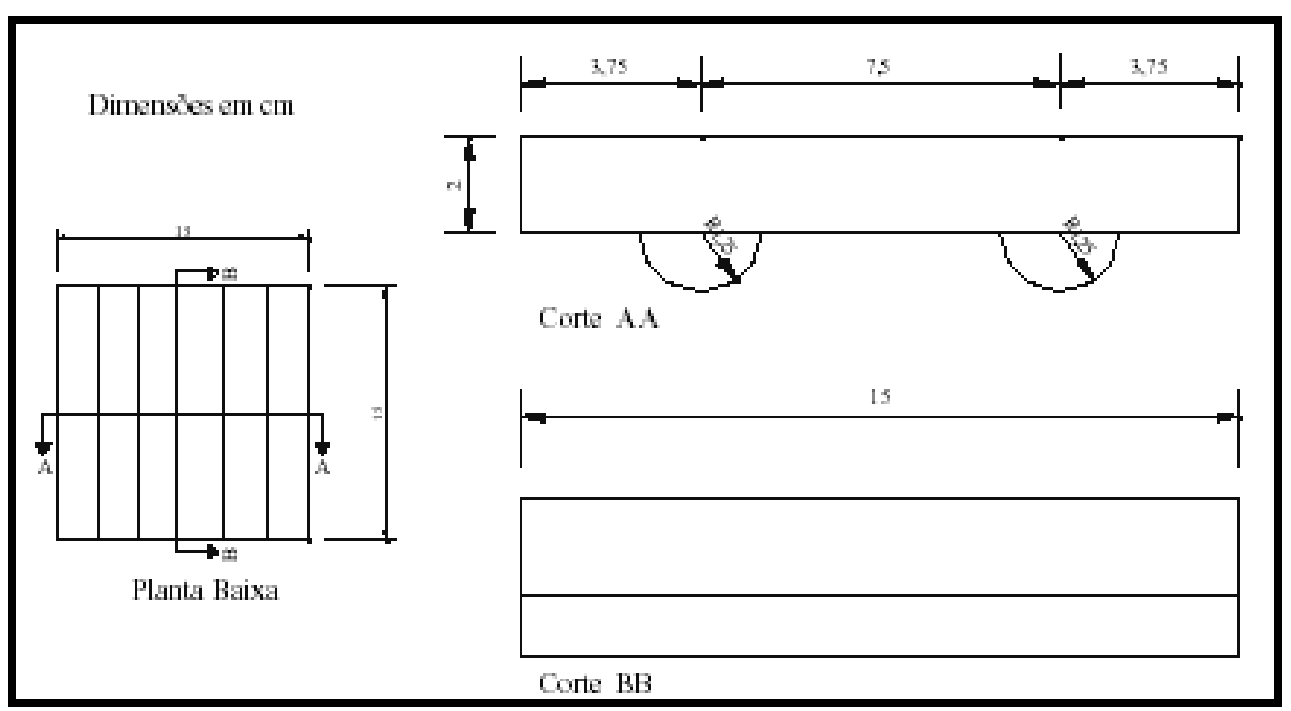

Figura 3.23 - Dispositivo metálico utilizado para ensaio de carga localizada

As placas eram cortadas em tiras de $2,5 \mathrm{~cm}$ de largura e, para tal, tornava-se necessária a ajuda dos técnicos do Laboratório de Geotecnia da Escola de Engenharia de São Carlos, o qual possuía uma máquina adequada para o corte das tiras. Para medição do afundamento utilizava-se um paquímetro digital e, anteriormente ao ensaio, era necessário lápis para marcação do posicionamento do ponto de aplicação da carga bem como régua ou trena para o mesmo fim. Como dito anteriormente, eram demarcadas 2 linhas, uma a cada $3,75 \mathrm{~cm}$ de cada borda das tiras de $2,5 \mathrm{~cm} \times 10 \mathrm{~cm}$. Sendo assim, tinham-se 4 pontos, 2 em cada linha, nos quais verificava-se a espessura exata da placa.

Aproveitavam-se as lascas de cada placa para verificação da carga última ou de ruptura de cada espessura de placa. Aplicava-se metade da carga de ruptura, referente à dada espessura, e verificava-se qual a nova espessura de cada um dos 4 pontos especificados. Tirava-se esta medida daquela efetuada antes do ensaio e verificava-se o afundamento de cada uma das regiões para metade da carga de ruptura de cada espessura. A seguir, repetia-se o procedimento para a carga de ruptura, estabelecia-se uma nova medida e tirava-se essa última da medida inicial, anterior ao ensaio, descobrindo-se o afundamento de cada posição para a carga última. 


\subsection{Ligações de blocos}

Neste caso, foram moldados blocos de concreto, com ou sem emenda e, nos casos de haver emenda, pode haver ou não almofada de apoio presente na emenda. Os corpos foram confeccionados em fôrmas de madeira prismáticas num traço especificado para um concreto de $\mathrm{f}_{\mathrm{ck}}=35 \mathrm{MPa}$.

Para o dado $\mathrm{f}_{\mathrm{ck}}$ tem-se o seguinte traço em massa (Tabela 3.12), de acordo com MIOTTO:

Tabela 3.12 - Traço em massa dos blocos de concreto (MIOTTO, 2002)

\begin{tabular}{||c|c|c|c||}
\hline Cimento & Areia & Pedrisco & $\mathbf{a} / \mathbf{c}$ \\
\hline 1 & 1,6 & 2,3 & 0,42 \\
\hline
\end{tabular}

Efetuaram-se ensaios com as seguintes dosagens para as almofadas de argamassa especial (Tabela 3.13):

Tabela 3.13 - Traços das almofadas utilizadas nas ligações

\begin{tabular}{||c|c|c||}
\hline $\begin{array}{c}\text { Consumo de } \\
\text { Vermiculita } \\
(\text { em \%) }\end{array}$ & $\begin{array}{c}\text { Taxa } \\
\text { volumétrica de } \\
\text { Látex (em \%) }\end{array}$ & $\begin{array}{c}\text { Taxa volumétrica de } \\
\text { fibra de PVA (em \%) }\end{array}$ \\
\hline 5 & 30 & 3 \\
\hline $\begin{array}{c}\text { Consumo de } \\
\text { Vermiculita } \\
(\text { em \%) }\end{array}$ & $\begin{array}{c}\text { Taxa } \\
\text { volumétrica de }\end{array}$ & $\begin{array}{c}\text { Taxa volumétrica de } \\
\text { fibra de vidro (em \%) }\end{array}$ \\
\hline 25 & 30 & 2 \\
\hline 50 & 30 & 2 \\
\hline \hline
\end{tabular}

Conforme apresentado na Tabela 3.13, foram ensaiadas três situações, a primeira utilizando fibra de PVA e as demais com a utilização de fibra de vidro. As almofadas do compósito possuíam $10 \mathrm{~cm}$ de lado e espessuras de $10 \mathrm{~mm}$ e $20 \mathrm{~mm}$ de argamassa de cimento e areia, com a introdução de fibra de PVA ou vidro e adição de Látex estirenobutadieno e vermiculita nas proporções especificadas. 
Os ensaios realizados foram de compressão, utilizando a máquina ELE international limited, presente no Laboratório de Estruturas da Escola de Engenharia de São Carlos (EESC/USP) e eram realizados com e sem a presença de almofada de apoio.

Na Figura 3.24, pode-se visualizar o esquema do ensaio de compressão dos protótipos com a presença da referida almofada entre eles na máquina ELE.

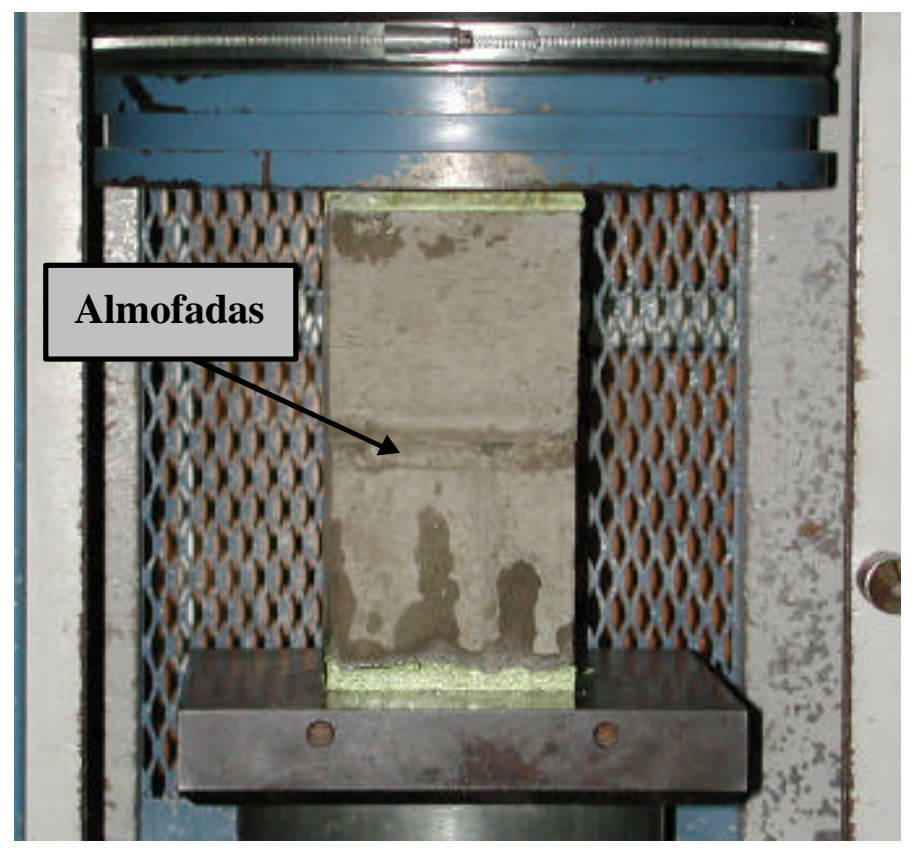

Figura 3.24 - Esquema do ensaio com a presença de almofada

Foram, portanto, realizados ensaios de compressão em corpos de prova de $20 \mathrm{~cm}$ de altura sem a utilização de almofada e ensaios de corpos-de-prova com metade desta altura com e sem a presença de almofada de apoio.

Estas placas seguem os mesmos padrões de moldagem, desmoldagem e cura daquelas que são submetidas ao ensaio isolado (afundamento e rigidez).

As séries que foram moldadas para a realização dos ensaios, em cada um dos três traços relatados, são descritas na seqüência. Em todos os casos, os corpos e almofadas possuíam área da base de $10 \mathrm{~cm} \times 10 \mathrm{~cm}$. As almofadas eram moldadas 14 dias antes do ensaio, sendo que 7 dias após a moldagem destas, elas eram colocadas no fundo das fôrmas de madeira onde haveria a cura do concreto e sobre as mesmas era colocado o concreto fresco; o conjunto fundido passava, dessa forma, por uma cura de 7 dias para posterior capeamento com enxofre e ensaio de compressão. 


\section{a) Série 1}

A $1^{\mathrm{a}}$ série de ensaios nos blocos de concreto é mostrada na Figura 3.25.

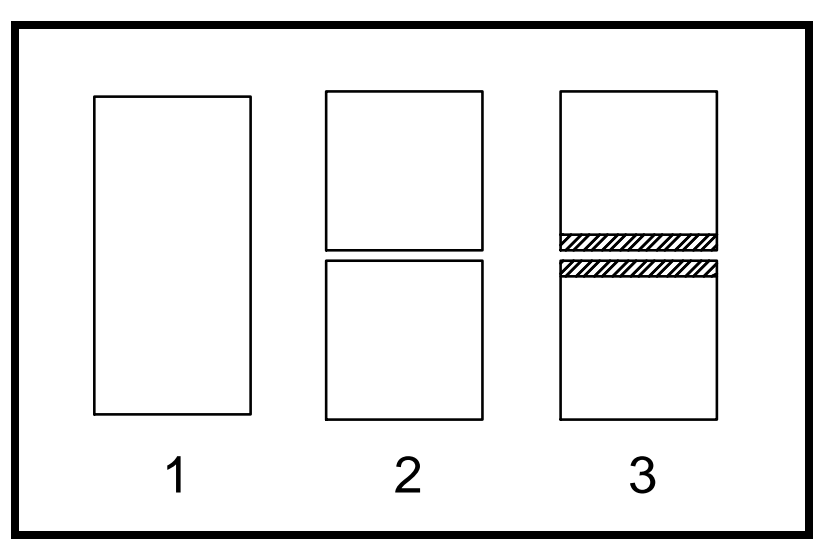

Figura 3.25 $-1^{\mathrm{a}}$ série de ensaios

Nessa série de ensaios foram efetuados 3 conjuntos: tipos 1, 2 e 3. Para o tipo 1 foram efetuados 2 corpos de prova isolados de $20 \mathrm{~cm}$ de altura. Para o tipo 2 foram efetuados 4 corpos com $10 \mathrm{~cm}$ de altura, sendo que os mesmos foram ensaiados a cada 2 . Para o ensaio tipo 3 também foram efetuados 4 corpos, entretanto estes possuíam apenas $9 \mathrm{~cm}$ de altura, sendo que o centímetro completar era composto por almofada do compósito moldada num dos três traços especificados no início deste capítulo; a almofada era, então, fundida em cada um dos blocos de concreto de $9 \mathrm{~cm}$, para ensaio de compressão superior (centrada).

\section{b) Série 2}

A $2^{\mathrm{a}}$ série de ensaios nos blocos de concreto é mostrada na Figura 3.26.

Nessa série de ensaios foram efetuados 3 conjuntos: tipos 1, 2 e 3. Para o tipo 1 efetuaram-se 2 corpos de prova isolados de $20 \mathrm{~cm}$ de altura. Para o tipo 2, efetuaram-se 4 corpos com maior altura $10 \mathrm{~cm}$ e menor altura $9 \mathrm{~cm}$, proporcionando uma inclinação de $10 \%$, sendo que os mesmos foram ensaiados a cada 2. Para o ensaio tipo 3 também se efetuaram 4 corpos, entretanto estes possuíam apenas $9 \mathrm{~cm}$ de maior altura e $8 \mathrm{~cm}$ de menor altura, sendo que o centímetro complementar era composto por almofada do compósito chumbada em cada um dos blocos de concreto, como visto na Figura 3.26, para ensaio de compressão superior (excêntrica). 


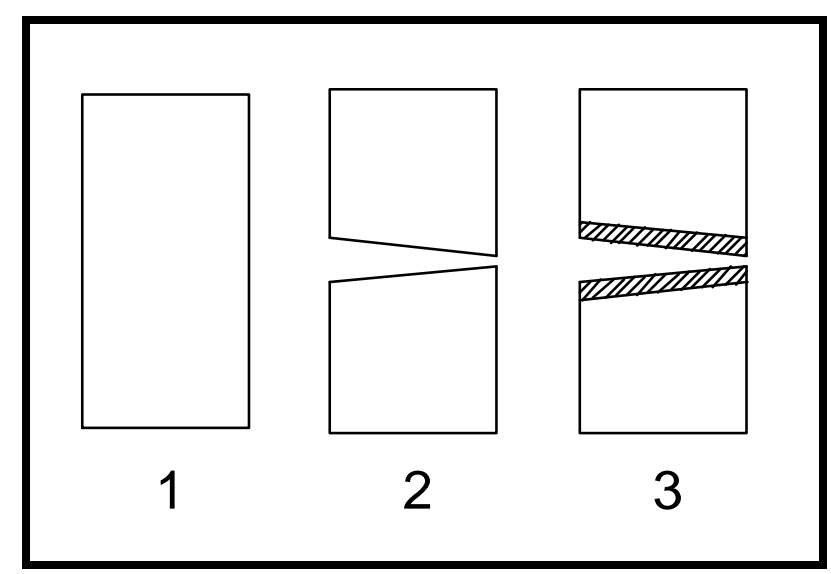

Figura 3.26 $-2^{\mathrm{a}}$ série de ensaios

\section{c) Série 3}

A $3^{\mathrm{a}}$ série de ensaios nos blocos de concreto é mostrada na Figura 3.27.

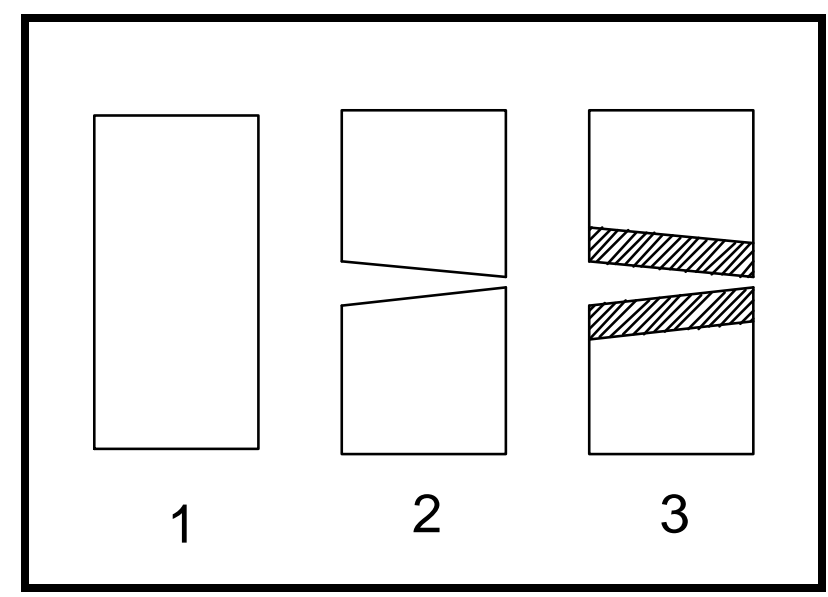

Figura 3.27 $-3^{\mathrm{a}}$ série de ensaios

Nessa série de ensaios efetuaram-se 3 protótipos: tipos 1, 2 e 3. Para o tipo 1, novamente, foram efetuados 2 corpos de prova isolados de $20 \mathrm{~cm}$ de altura. Para o tipo 2 efetuaram-se 4 corpos com maior altura $10 \mathrm{~cm}$ e menor altura $9 \mathrm{~cm}$, proporcionando uma inclinação de $10 \%$, sendo que os mesmos foram ensaiados a cada 2 , de forma idêntica àquela da série 2. Para o ensaio tipo 3 também se efetuaram 4 corpos, entretanto estes possuíam apenas $8 \mathrm{~cm}$ de maior altura e $7 \mathrm{~cm}$ de menor altura, sendo que os dois centímetros complementares eram compostos por almofada do compósito, a qual era 
fundida em cada um dos blocos de concreto, como visto na Figura 3.27, para ensaio de compressão superior (excêntrica).

\section{d) Série 4}

A $4^{\mathrm{a}}$ série de ensaios nos blocos de concreto é mostrada na Figura 3.28.

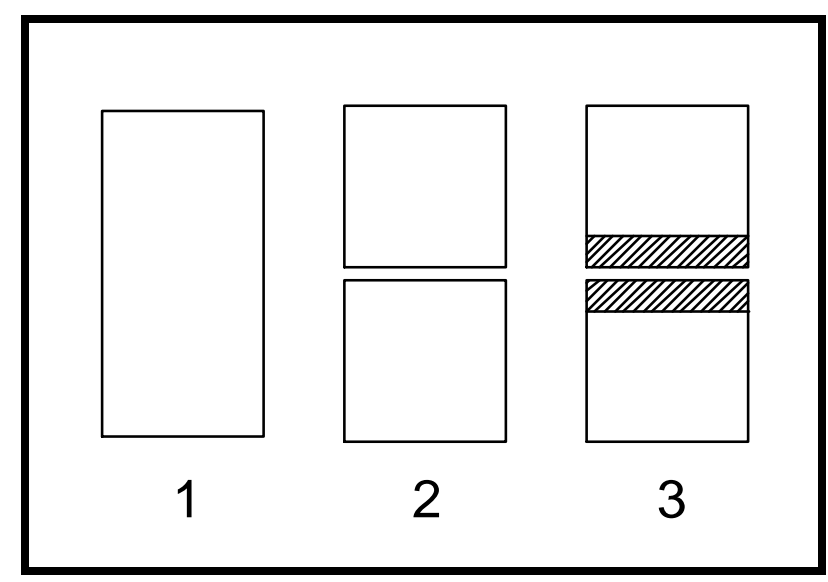

Figura 3.28 $-4^{\mathrm{a}}$ série de ensaios

Esta série de ensaios era idêntica à série 1, com distinção apenas no ensaio tipo 3, pois, neste caso, utilizaram-se almofadas de $20 \mathrm{~mm}$ de altura fundidas aos corpos de prova (compressão centrada) em substituição às almofadas de $10 \mathrm{~mm}$ utilizadas naquele caso.

\section{e) Série 5}

A $5^{\mathrm{a}}$ série de ensaios nos blocos de concreto é mostrada na Figura 3.29.

Esta série de ensaios era idêntica à série 3, com distinção apenas nos ensaios dos tipos 2 e 3, pois nestes casos utilizaram-se almofadas de $10 \mathrm{~mm}$ de altura fundidas aos corpos de prova, com inclinação de 5\% em substituição à inclinação de $10 \%$ utilizada naquela série (compressão excêntrica). 


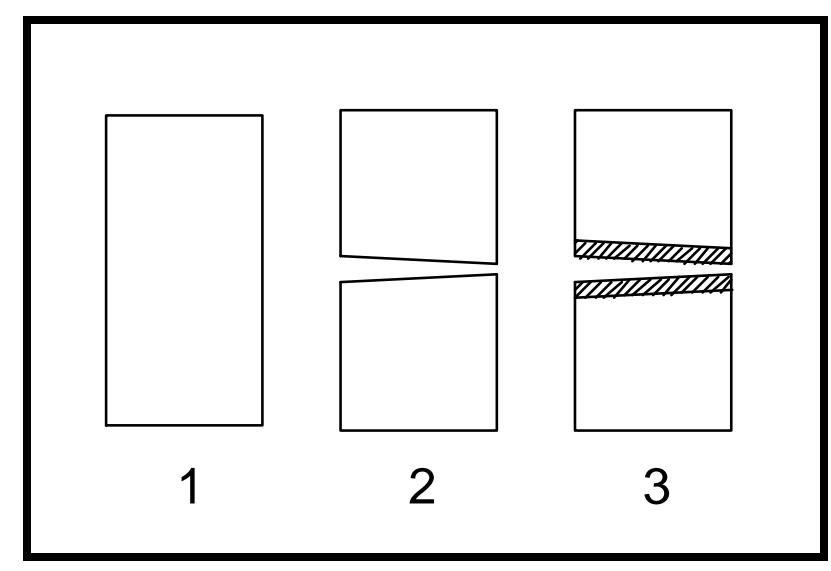

Figura 3.29 $-5^{\mathrm{a}}$ série de ensaios

As séries de ensaios realizadas nos corpos-de-prova isolados e nestes com a presença das almofadas de apoio (fundidas ou não nos corpos-de-prova) são mostradas na Tabela 3.14 (em resumo), na qual pode-se visualizar as 5 séries de moldagens e ensaios realizados. A letra $i$ representa a inclinação da almofada e a letra $e$ a espessura dela.

Tabela 3.14 - Ensaios de ligações realizados (resumo)

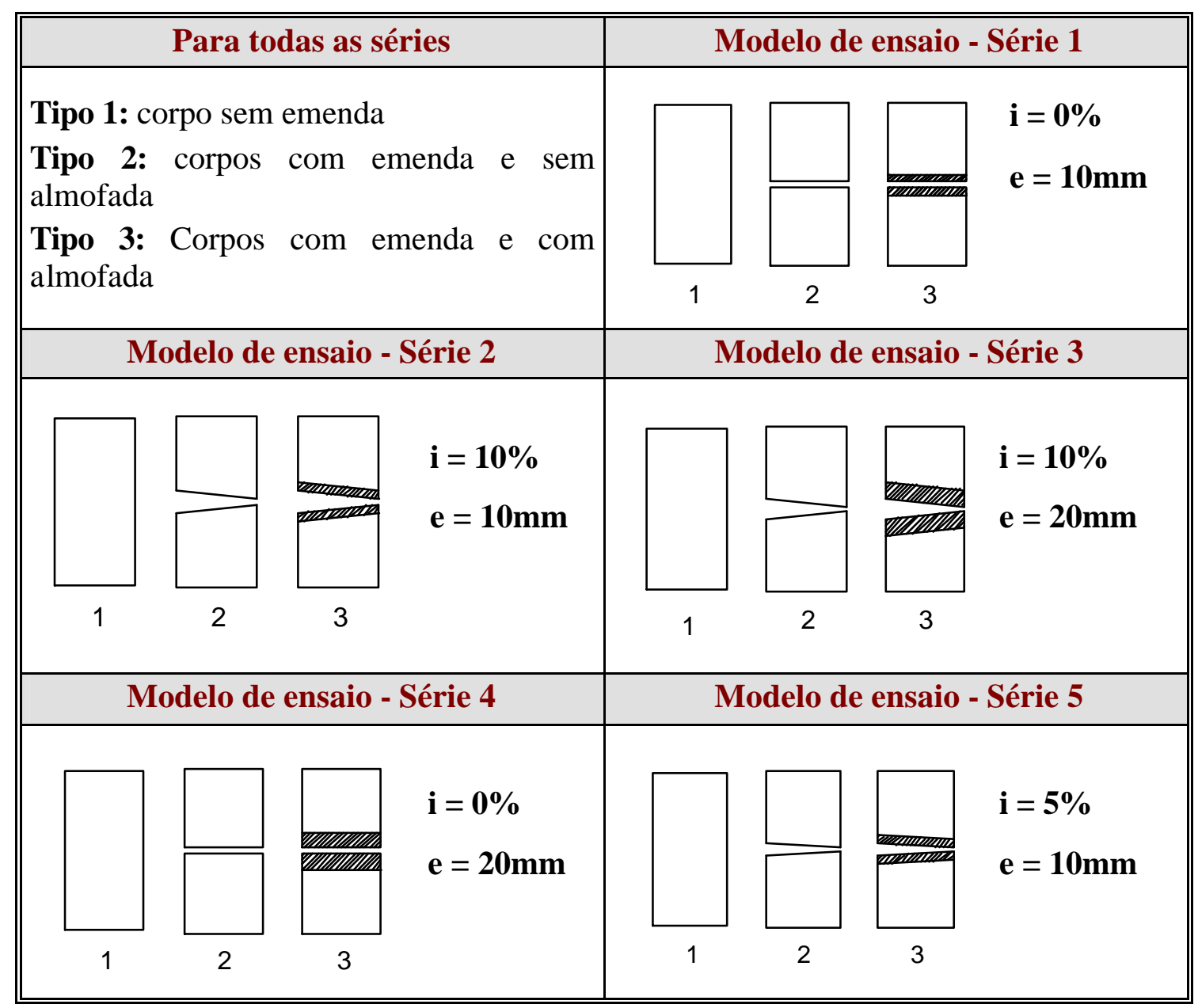


As séries 1 e 4, em que não há excentricidade na ligação entre os blocos, simula uma ligação entre paredes pré-moldadas de concreto.

As demais séries apresentam excentricidade na ligação e foram efetuadas para simular uma ligação viga-pilar, na qual a inclinação (excentricidade) representa o giro da viga sobre o pilar.

Na Figura 3.30 pode-se verificar o esquema de aplicação de carga para corpos sem emenda, com emenda e sem almofada e com emenda e com almofada, que corresponde à série 2 citada anteriormente.

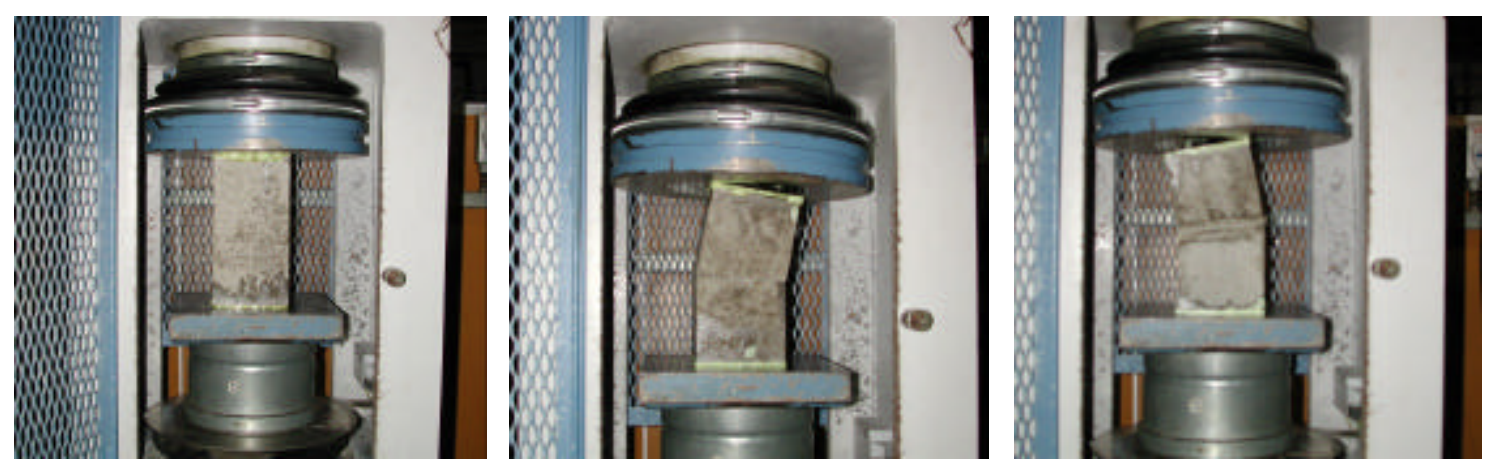

Figura 3.30 - Aplicação de carga na ELE em protótipos da série 2

$$
(\mathrm{i}=10 \% \text { e } \mathrm{a}=10 \mathrm{~mm})
$$




\section{RESULTADOS E ANÁLISES}

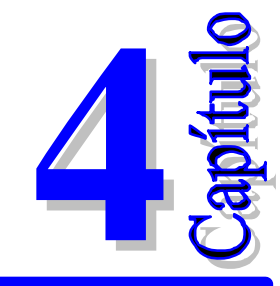

\subsection{Características do material}

Neste capítulo, tratar-se-á especificamente dos resultados experimentais dos corpos-de-prova para determinação das características do material em estudo, tais como: resistência à compressão, resistência à tração por compressão diametral e módulo de elasticidade. Para tal, estabelecer-se-á uma análise crítica dos resultados a fim de distinguir as principais características para cada um dos traços e aplicá-los posteriormente às almofadas.

\subsubsection{Resistência à compressão}

Neste capítulo serão apresentados os resultados referentes aos ensaios de compressão axial. Inicialmente, mostrar-se-á um traço com os resultados dos 4 corposde-prova e a média entre estes resultados, para verificar a variação dos resultados entre os corpos-de-prova.

Os resultados apresentados na Tabela 4.1 correspondem ao traço V5L30F3.

Tabela 4.1 - Resultados dos CPs para o traço V5L30F3 - compressão

\begin{tabular}{||c|c|c|c||}
\hline \hline V5L30F3 & $\begin{array}{c}\text { Resistência à } \\
\text { compressão (MPa) }\end{array}$ & \multirow{2}{*}{$\begin{array}{c}\text { Média dos 4 } \\
\text { CPs (MPa) }\end{array}$} & $\begin{array}{c}\text { Desvio } \\
\text { padrão da } \\
\text { média }\end{array}$ \\
\cline { 1 - 2 } $\mathbf{1}^{\mathbf{0}} \mathbf{C P}$ & 35,67 & \multirow{2}{*}{34,46} & \multirow{2}{*}{1,05} \\
\cline { 1 - 2 } $\mathbf{2}^{\mathbf{0}} \mathbf{C P}$ & 34,39 & & \\
\cline { 1 - 2 } $\mathbf{3}^{\mathbf{0}} \mathbf{C P}$ & 33,12 & & \\
\cline { 1 - 2 } $\mathbf{4}^{\mathbf{0}} \mathbf{C P}$ & 34,65 & & \\
\hline
\end{tabular}


Calculada a média dos 4 corpos-de-prova e o respectivo desvio padrão das amostras, basta calcular a nova média levando em conta o desvio padrão pelo critério de Chauvenet. Verificou-se, neste caso, que a dispersão entre os valores das resistências à compressão dos 4 corpos-de-prova era muito pequena. Dessa forma, a média será

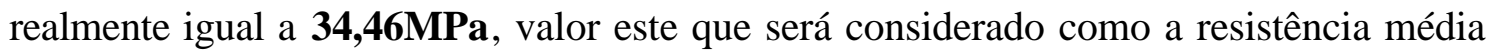
à compressão do traço V5L30F3. Os cálculos das resistências à compressão dos outros traços foram efetuados da mesma forma e as comparações dos resultados de todos os traços são apresentadas na seqüência.

Na Figura 4.1, pode-se observar um gráfico comparativo das tensões máximas de cada traço ao se utilizar fibras de PVA ou de vidro. Fazendo-se uma análise dos resultados deste tipo de ensaio pode-se notar com clareza a influência da vermiculita em cada mistura. À medida que se acrescenta mais vermiculita à mistura, nota-se que a resistência à compressão dos corpos-de-prova diminui. Em geral, também se pode notar no gráfico que o acréscimo de fibras à mistura também acarreta ganho de resistência ao corpo-de-prova, sobretudo nos casos em que se utiliza fibra de vidro. Com relação ao látex, nota-se, de maneira prévia, que a adição do produto, sobretudo para quantidades superiores a $30 \%$, tem proporcionado queda nos valores das resistências.

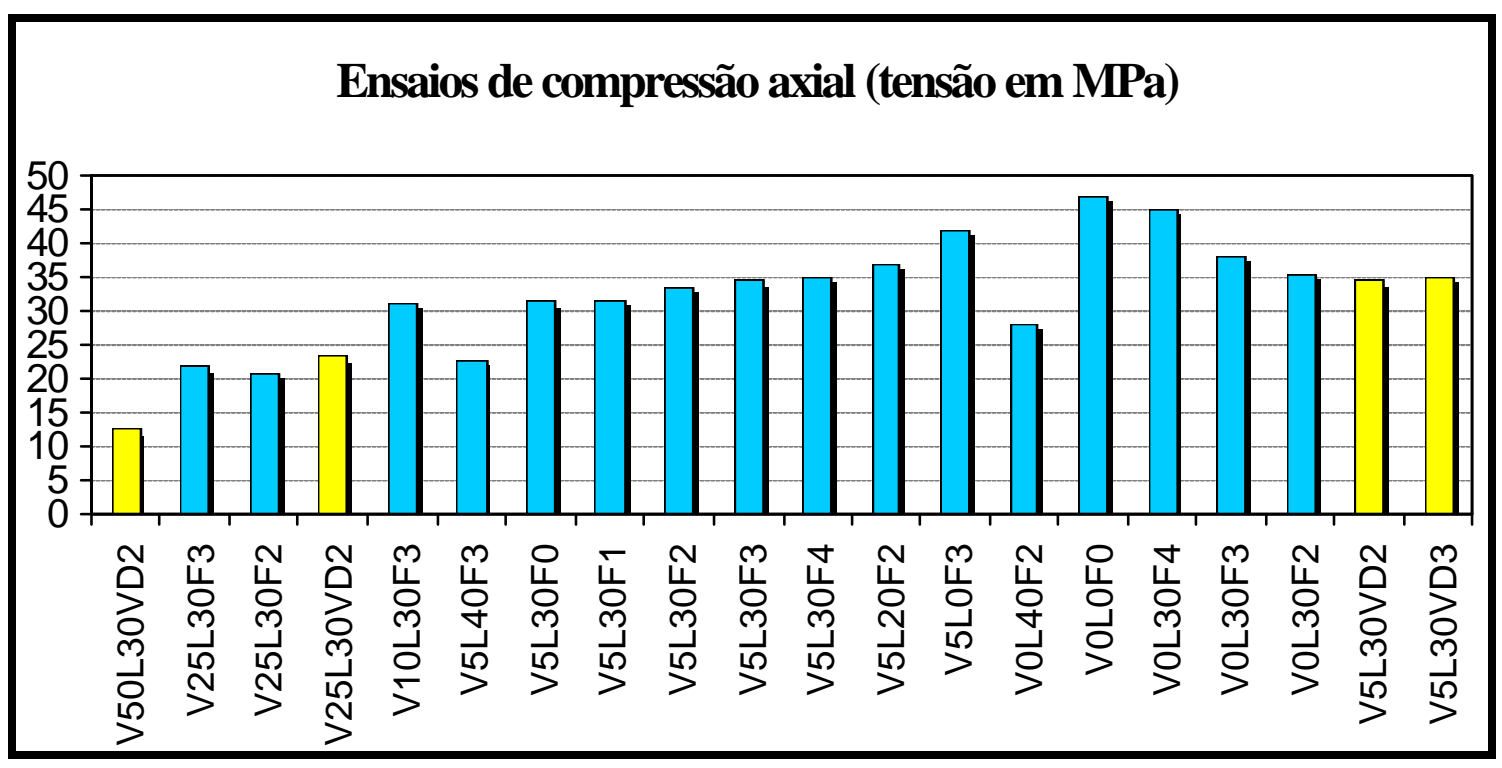

Figura 4.1 - Gráfico comparativo das tensões para ensaio de compressão axial

Para melhor avaliação dos resultados deste tipo de ensaio, propõe-se, na seqüência, a utilização de gráficos com nenor número de traços a serem avaliados, 
fixando a quantidade de um ou mais materiais e verificando a influência da variação das quantidades de cada um deles, bem como as dificuldades que proporcionam na moldagem dos corpos.

Utilizando-se maior quantidade de vermiculita (Figura 4.2), a tendência é de se diminuir a resistência e o peso do corpo-de-prova; cabe destacar também que o aumento na quantidade do material torna a almofada do referido compósito menos rígida.

\section{Resistência à compressão com látex constante (tensão em MPa)}

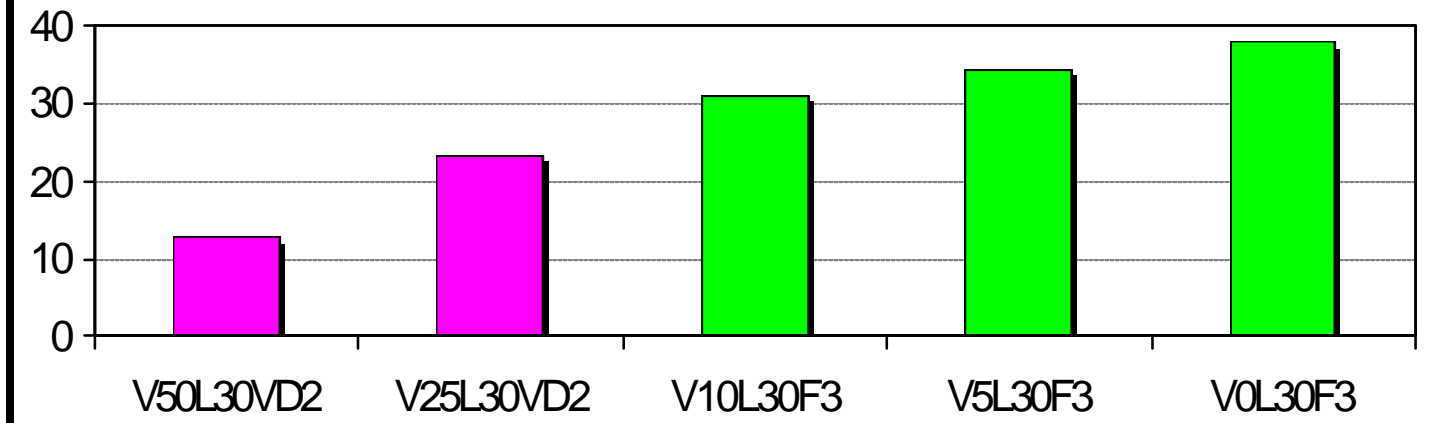

Figura 4.2 - Gráfico das tensões para ensaio de compressão axial (látex constante)

Observando-se apenas as três misturas em que se utiliza fibra de PVA (3\%) e nas quais a quantidade de látex é constante $(30 \%)$, pode-se notar que a cada $5 \%$ de vermiculita que se acrescenta tem-se uma diminuição da resistência de, aproximadamente, $10 \%$.

No caso da $1^{\text {a }}$ mistura em que se utiliza fibra de vidro (V50L30VD2), pode-se notar que sua resistência é bastante inferior à das demais, todavia na seqüência dos resultados poderá ser notado que esta diferença não se deve ao tipo de fibra mas à vermiculita.

$\mathrm{Na}$ seqüência, fixar-se-á a quantidade de vermiculita em $0 \%, 5 \%$ ou $25 \%$ e verificar-se-á a influência de cada um dos outros materiais nas misturas.

Primeiramente, far-se-á uma análise do compósito sem vermiculita. 


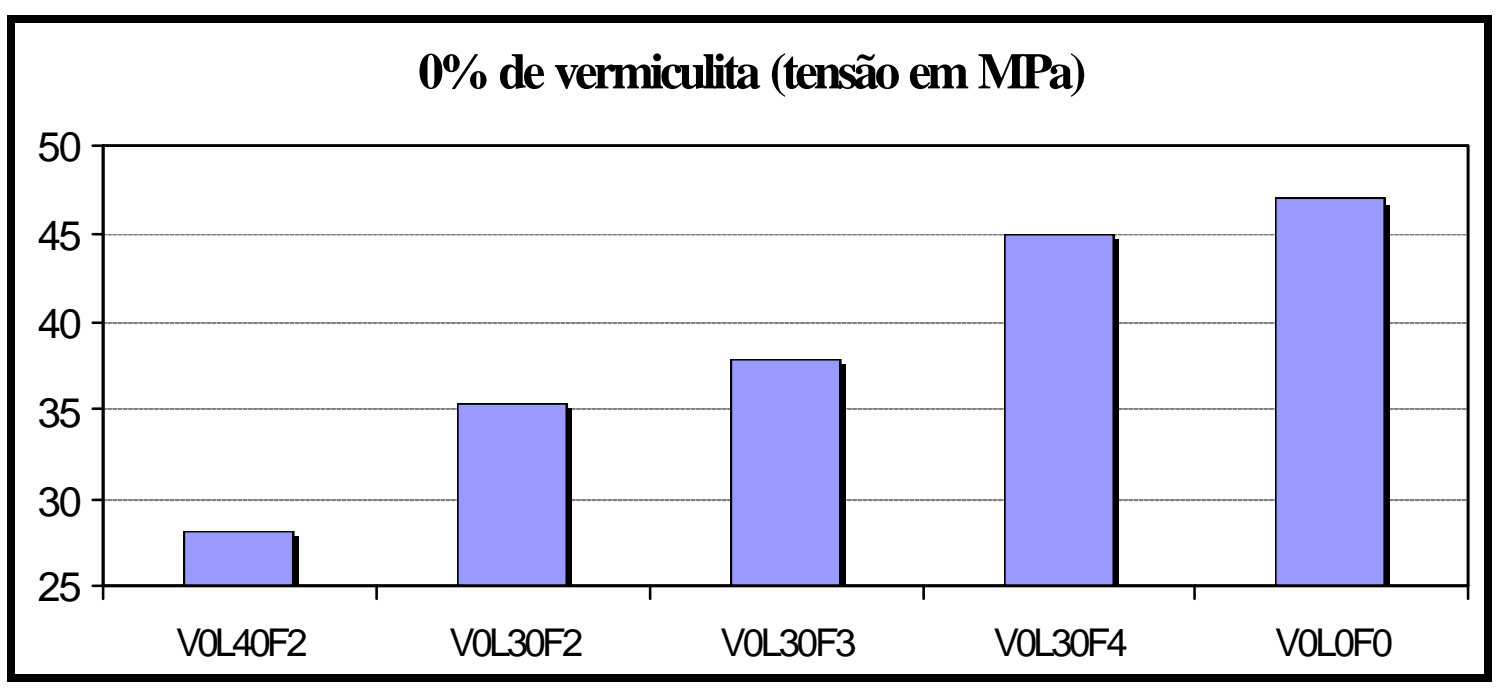

Figura 4.3 - Gráfico das tensões para ensaio de compressão axial (sem vermiculita)

Na Figura 4.3, pode-se verificar que ao se utilizar uma argamassa simples (VOLOF0) se obtém uma resistência maior que nos casos em que se utiliza látex e/ou fibra de PVA.

Ao se comparar as duas primeiras misturas da Figura 4.3 (VOL40F2 e V0L30F2), variando apenas o látex, pode-se notar a influência do acréscimo de látex na diminuição da resistência do corpo-de-prova à compressão axial, sendo que a diminuição do valor, neste caso, é superior a $20 \%$ ao se acrescentar $10 \%$ de látex; na mesma figura também se apresenta a argamassa simples e se pode notar que sua resistência é bastante superior às demais, sendo seu valor praticamente $30 \%$ superior ao valor da segunda mistura (VOL30F2). Todavia, essa argamassa simples sofre ruptura brusca (frágil) e é pouco macia, tornando-se inadequada para a utilização como almofada de apoio, sendo seu resultado utilizado apenas para comparação com os dos demais traços, a fim de se moldar traços em que a resistência também tenha um valor considerado razoável (muitas vezes até maior que o da argamassa simples), mais macia, com facilidade de moldagem e adequado para a utilização como almofada de apoio.

Quando se trata da $3^{\mathrm{a}}$ e $4^{\mathrm{a}}$ misturas da Figura 4.3 (V0L30F3 e V0L30F4), nas quais se varia apenas a quantidade de fibra de PVA, nota-se a influência no acréscimo da resistência ao se adicionar maiores quantidades da fibra em questão. Neste caso, ao se acrescentar $1 \%$ de fibra de PVA tem-se um acréscimo de resistência de aproximadamente $20 \%$. 


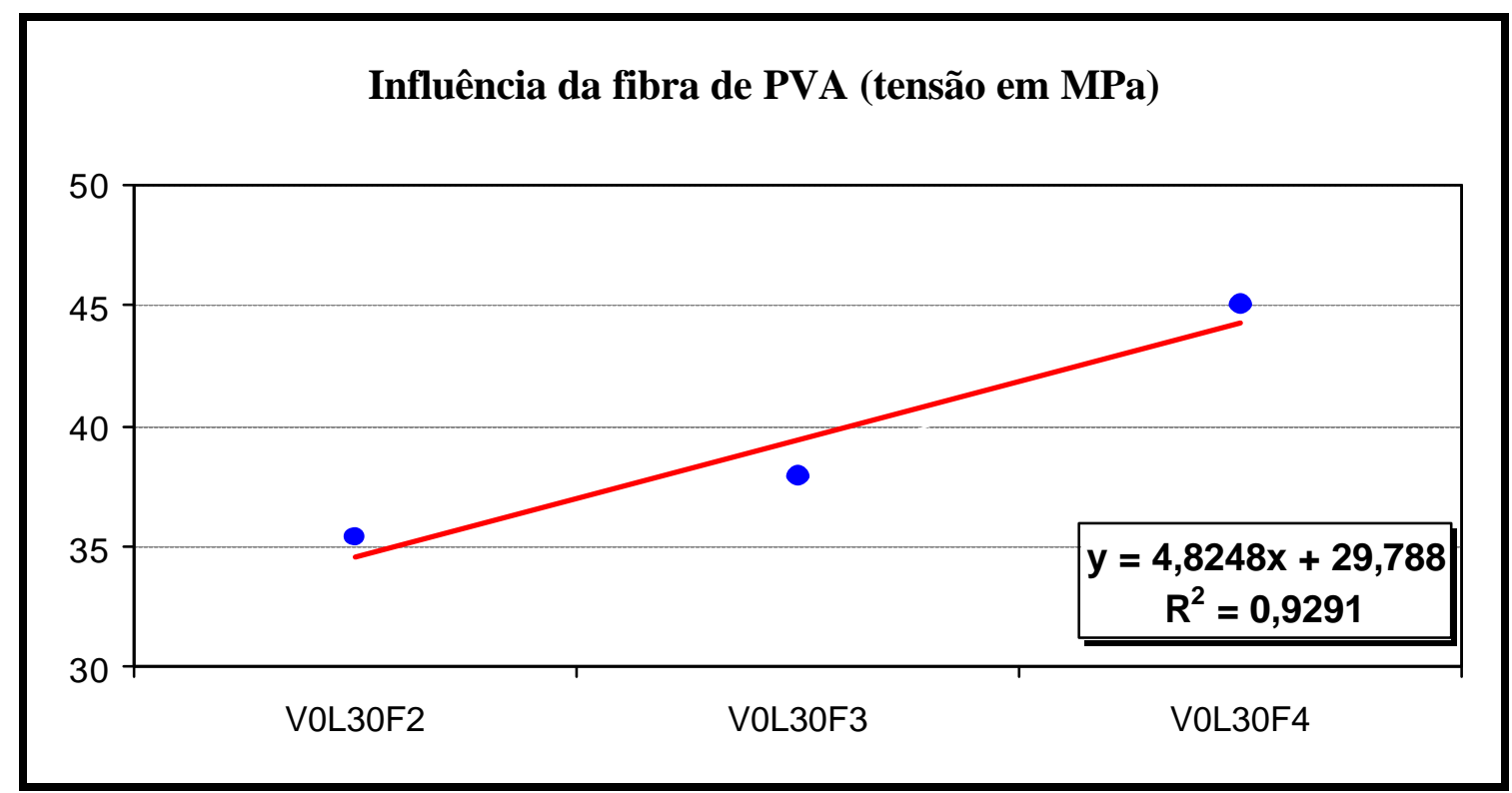

Figura 4.4 - Influência da fibra de PVA (sem vermiculita e 30\% de látex)

Para melhor constatar a influência da fibra de PVA para os traços dos corpos-deprova sem vermiculita, optou-se por se construir uma reta mostrando uma equação aproximada das quantidades de fibras de PVA e, a partir dessa equação, pode-se ter uma idéia dos resultados a serem obtidos para outras quantidades de fibra, para essa mesma quantidade de látex e sem que se utilize vermiculita. Deve ser ressaltado que a aproximação dessa reta ainda não é tão precisa, pois o coeficiente de correlação $R^{2}$ é inferior a $93 \%(0,9291)$, sendo que ela seria precisa com $\mathrm{R}^{2}$ igual a $100 \%(1,0000)$.

Na seqüência, far-se-á uma análise do compósito utilizando uma pequena quantidade de vermiculita, $5 \%$.

Pode-se verificar que ao se utilizar menores quantidades de látex obtém-se corposde-prova com resistências maiores. De maneira prévia, pode-se notar que ao se acrescentar maiores quantidades de fibra de PVA à mistura, obtém-se corpos-de-prova com maiores resistências. Ao se comparar a influência das fibras de PVA e de vidro, pode-se notar que os resultados são bastante semelhantes.

Para que a comparação possa ser melhor realizada, optou-se por separar apenas algumas misturas na Figura 4.5, fixando-se a quantidade de vermiculita em $5 \%$ e variando a quantidade de fibras e, numa única mistura, utilizando uma menor quantidade de látex. 


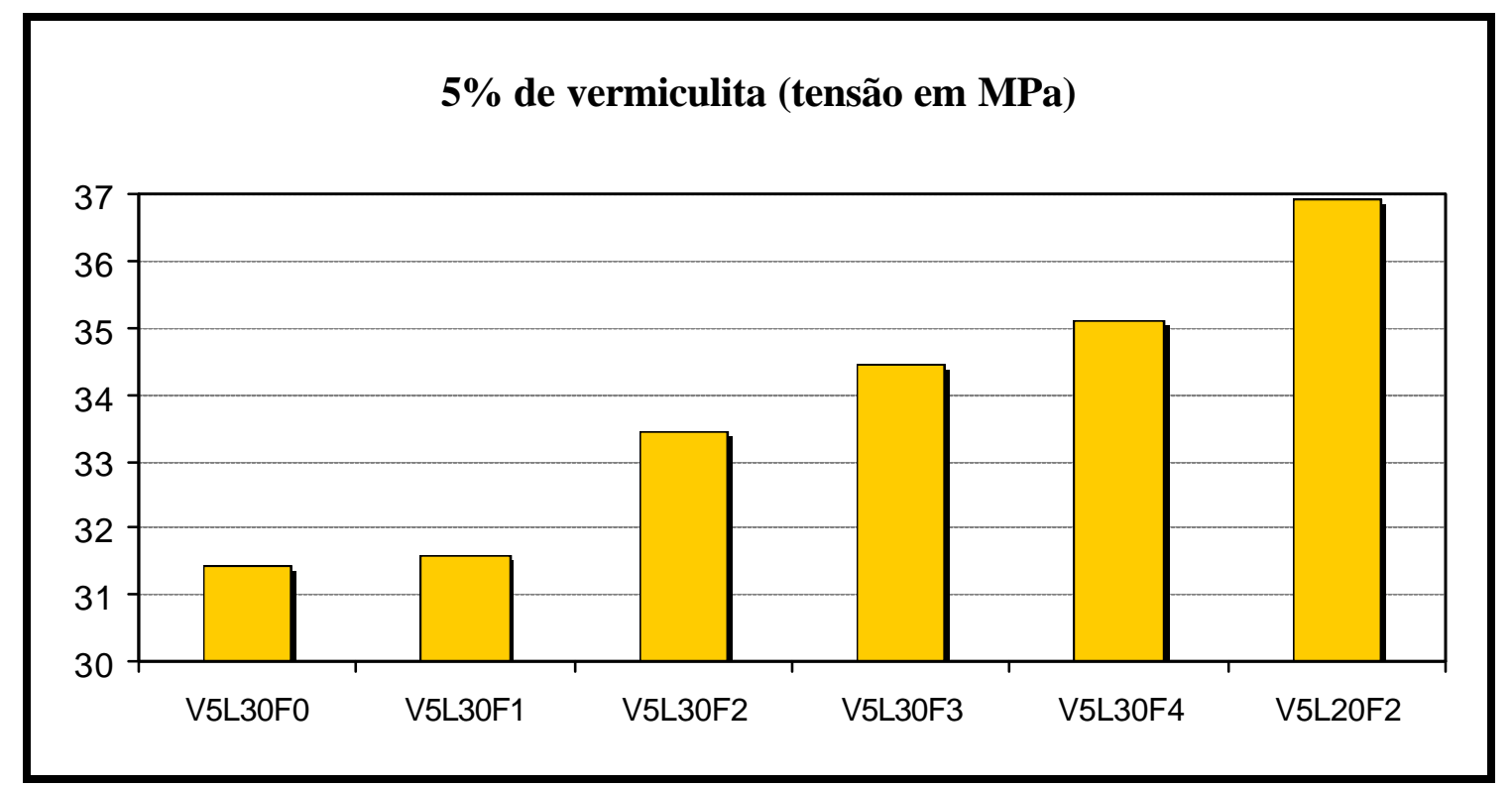

Figura 4.5 - Ensaio de compressão axial variando fibra de PVA (5\% de vermiculita)

$\mathrm{Na}$ Figura 4.5, mantém-se a quantidade de vermiculita em 5\% e nota-se, claramente, que o acréscimo de fibra atribui maior resistência aos corpos-de-prova. Também se diminuiu a quantidade de látex em uma das misturas e notou-se que a tensão atingiu um maior valor.

Pode-se verificar também que ao se utilizar uma argamassa com menor quantidade de látex, como é o caso da última mistura do gráfico da Figura 4.5 (V5L20F2), obtém-se corpos-de-prova com maior resistência. Ao se comparar a última mistura tratada à terceira mistura mostrada no gráfico (V5L30F2), pode-se notar que a mistura com $20 \%$ de látex possui uma resistência aproximadamente $10 \%$ superior à daquela mistura com $30 \%$ de látex e as mesmas quantidades de fibra de PVA e vermiculita.

Ao se comparar as misturas V5L30F0 e V5L30F1, variando apenas a quantidade de fibra de PVA, pode-se notar a influência do acréscimo de fibra para aumentar a resistência do corpo-de-prova à compressão axial. O acréscimo do valor, neste caso, é ainda praticamente insignificante (ao se acrescentar $1 \%$ de fibra de PVA). Este acréscimo é muito baixo se comparado àqueles obtidos ao se utilizar maiores quantidades de fibra. Como exemplo, pode-se comparar a mistura com $2 \%$ de fibra à mistura com $3 \%$ do mesmo material, já que, neste caso, pode-se verificar um acréscimo de quase $6 \%$ na resistência à compressão. 


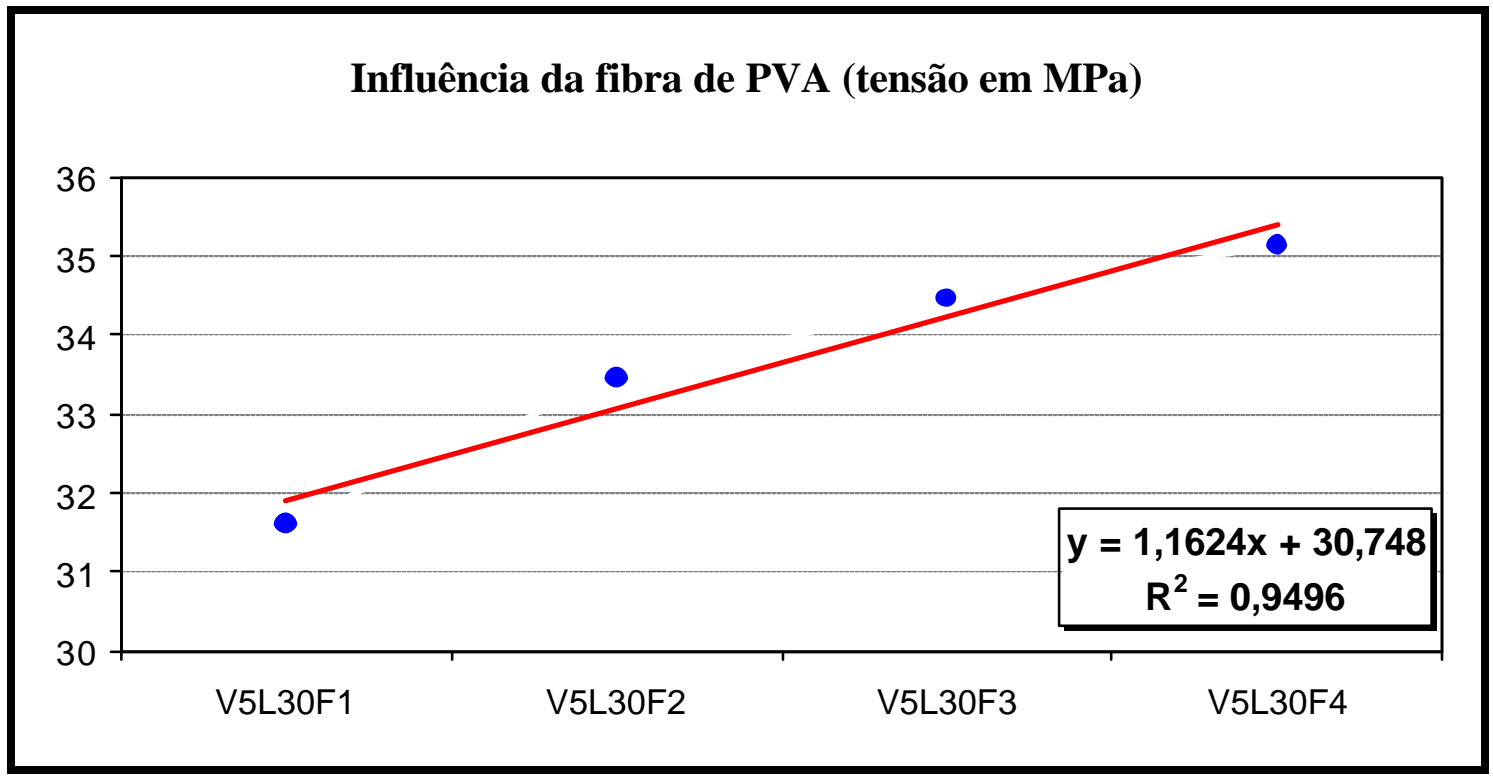

Figura 4.6 - Influência da fibra de PVA (5\% de vermiculita e 30\% de látex)

Para melhor constatar a influência da fibra de PVA para os traços dos corpos-deprova com pequena quantidade de vermiculita (5\%), optou-se por se construir uma reta mostrando uma equação aproximada das quantidades de fibras de PVA (Figura 4.6) e, a partir dessa equação, pode-se ter uma idéia dos resultados a serem obtidos para outras quantidades de fibra, para essa mesma quantidade de látex e vermiculita. Poder-se-ia utilizar, por exemplo, traços com $1,5 \%$ ou $2,5 \%$ de fibra para verificação dos resultados. Deve-se ressaltar que a aproximação dessa reta ainda não é muito precisa, pois o coeficiente de correlação $R^{2}$ é de quase $95 \%(0,9496)$, sendo que ela seria precisa com $\mathrm{R}^{2}$ igual a $100 \%(1,0000)$. Ao se comparar essa aproximação para $5 \%$ de vermiculita $\left(\mathrm{R}^{2}=0,9496\right)$ com aquela obtida para as misturas sem vermiculita $\left(\mathrm{R}^{2}=0,9291\right)$ nota-se que esta já apresenta um resultado mais preciso.

Ao se comparar as fibras de PVA e vidro para misturas com 5\% de vermiculita, conforme pode ser visto na Figura 4.7, pode-se notar que, geralmente, os valores das resistências para as misturas utilizando fibra de vidro são superiores aos valores para as mesmas misturas ao se utilizar fibra de PVA. Para o primeiro traço desta figura, o acréscimo percentual em razão da utilização de fibra de vidro em substituição à de PVA ( $2 \%$ ) é de $2,75 \%$ ao passo que para a outra mistura ( $3 \%$ de fibra) o acréscimo percentual é um pouco menor, aproximadamente $2,10 \%$, portanto também superior a $2 \%$. 


\section{Gráfico comparativo entre PVA e vidro (tensão em MPa)}

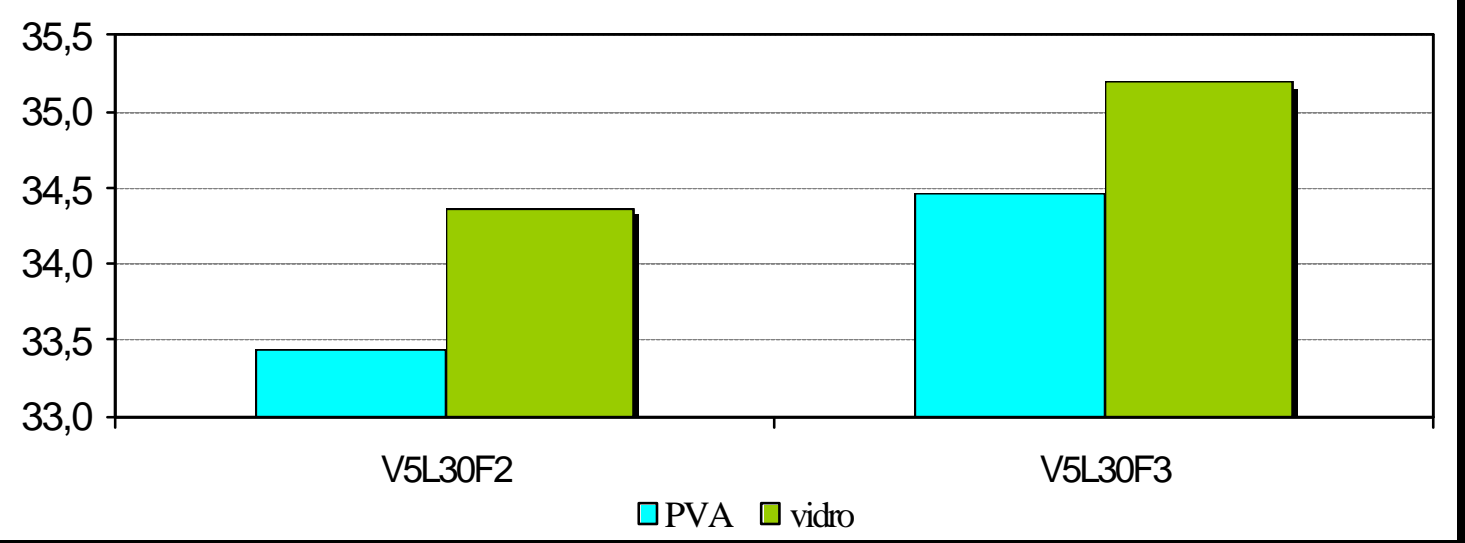

Figura 4.7 - Comparação entre fibra de PVA e vidro (5\% de vermiculita)

Na seqüência, far-se-á uma análise do compósito utilizando uma quantidade maior de vermiculita, $25 \%$.

Ao se utilizar esta quantidade de vermiculita, havia maior dificuldade para a moldagem dos corpos-de-prova, visto que o material em questão possui grande capacidade de retenção de água e, para alguns traços, como no caso de se moldar os corpos com $2 \%$ de fibra de vidro, havia necessidade de se utilizar aditivo superplastificante.

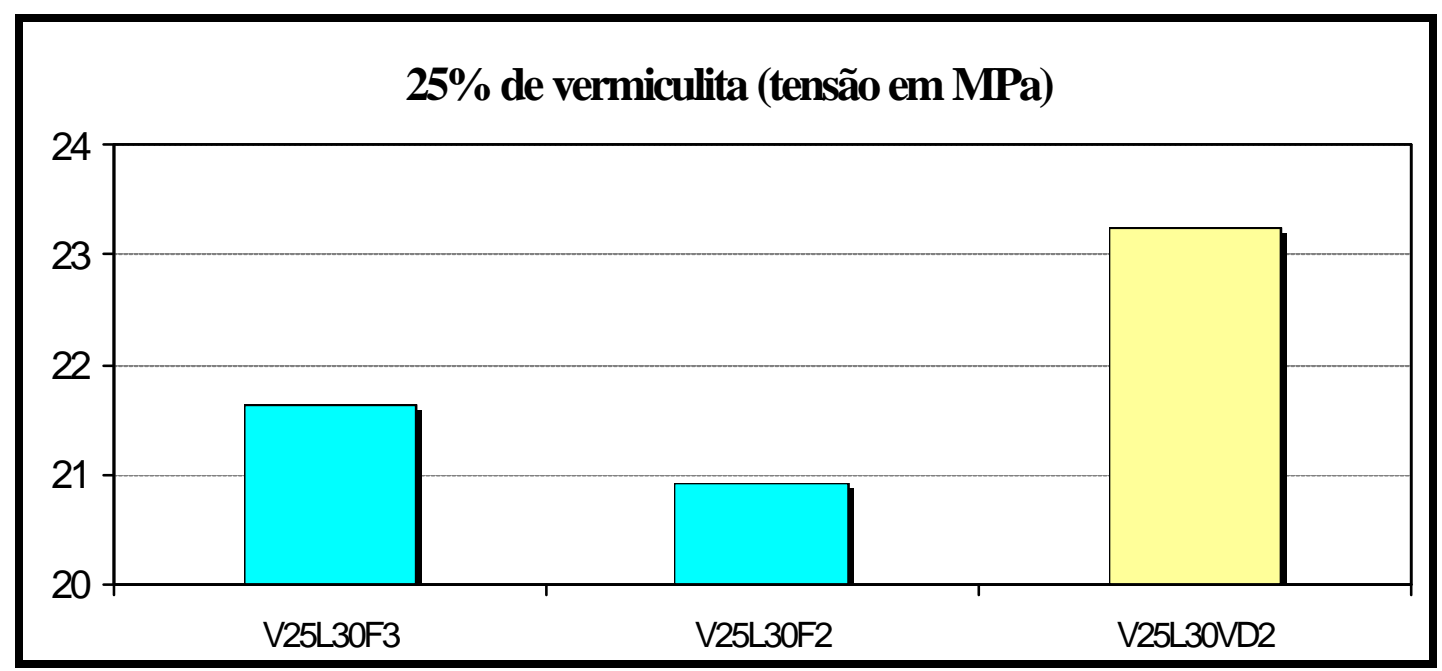

Figura 4.8 - Ensaio de compressão axial (25\% de vermiculita) 
Comparando-se inicialmente as duas primeiras misturas da Figura 4.8, ambas utilizando fibra de PVA (V25L30F3 e V25L30F2), nota-se novamente a influência da fibra de PVA no acréscimo de resistência dos corpos-de-prova. O simples acréscimo de $1 \%$ de fibra de PVA, promoveu um aumento de quase $5 \%$ na resistência à compressão axial dos corpos.

Entretanto, ao se comparar misturas com as mesmas quantidades de vermiculita $(25 \%)$ e látex (30\%) e substituindo a fibra de PVA por fibra de vidro (2\% em massa), obtém-se um acréscimo de aproximadamente $12 \%$ na resistência à compressão axial.

Também se percebe que as misturas adquirem uma consistência mais macia e permitem um maior afundamento do corpo-de-prova, com menores fissuras.

Na seqüência, fixar-se-á a quantidade de látex em $0 \%$ ou $30 \%$ e verificar-se-á a influência de cada um dos outros materiais nas misturas.

Na Figura 4.9, pode-se verificar que ao se utilizar uma argamassa simples (V0L0F0) se obtém uma resistência maior que nos casos em que se utiliza vermiculita e fibra de PVA, como é o caso da outra mistura tratada no gráfico (V5L0F3).

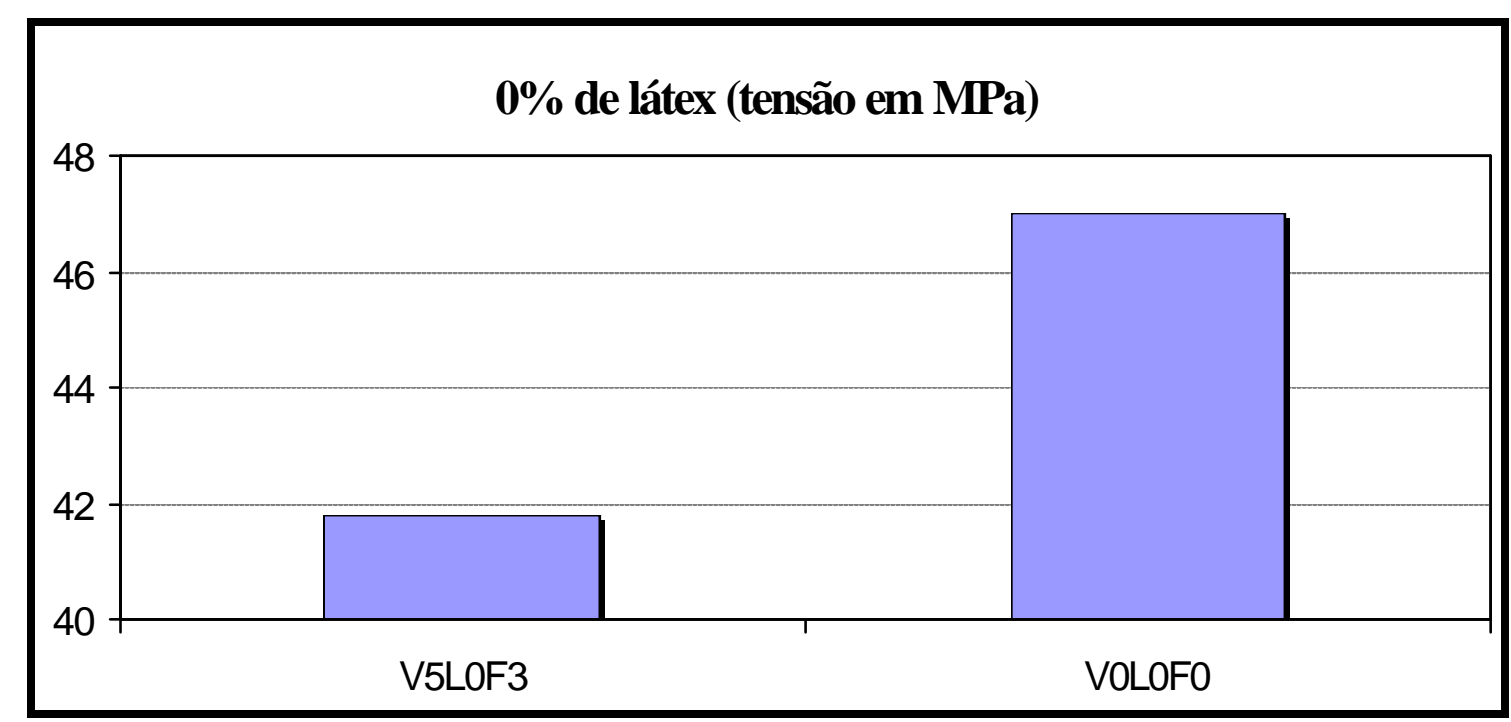

Figura 4.9 - Ensaio de compressão axial (sem látex)

O acréscimo de 5\% de vermiculita e 3\% de fibra de PVA promoveu um traço cuja resistência à compressão axial dos corpos-de-prova diminuiu cerca de $12 \%$. Todavia, a argamassa simples (V0L0F0) sofre ruptura brusca (frágil) e é pouco macia, tornando-se 
inadequada para a utilização como almofada de apoio, sendo seu resultado utilizado apenas para comparação com os dos demais traços, a fim de se moldar traços em que a resistência também tenha um valor considerado razoável (muitas vezes até maior que o da argamassa simples), com menor dureza, facilidade de moldagem e adequado para a utilização como almofada de apoio.

Na Figura 4.10, pode-se observar um gráfico comparativo das tensões máximas de cada traço ao se utilizar fibras de PVA ou de vidro, fixando a proporção de látex estireno-butadieno em $30 \%$.

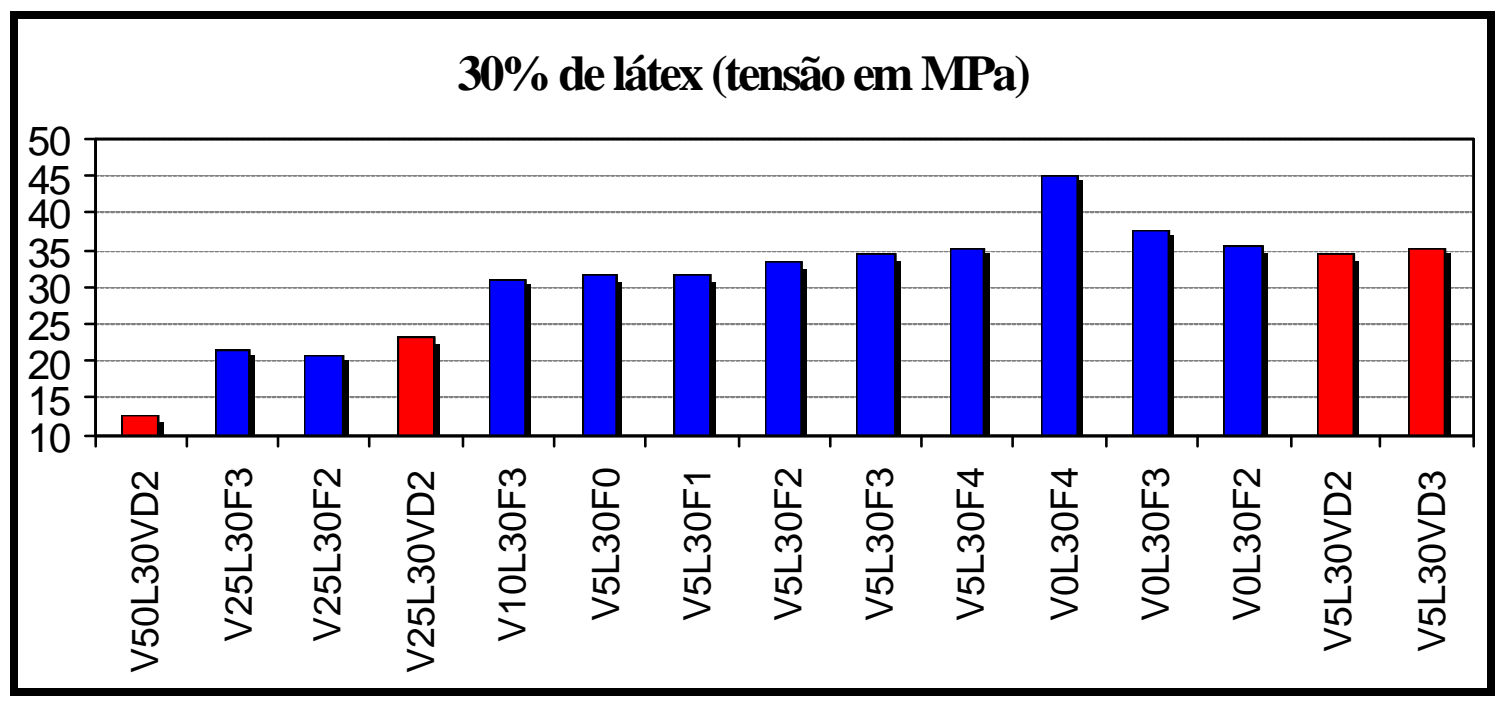

Figura 4.10 - Ensaio de compressão axial (30\% de látex)

Fazendo-se uma análise dos resultados deste tipo de ensaio pode-se notar com clareza a influência da vermiculita em cada mistura. À medida que se acrescenta vermiculita à mistura, nota-se que a resistência à compressão axial dos corpos-de-prova diminui.

Para melhor constatar a influência da vermiculita para os traços dos corpos-deprova com quantidade de fibra de PVA fixada em 3\%, optou-se por se construir uma reta mostrando uma equação aproximada da quantidade de vermiculita (Figura 4.11) e, a partir dessa equação, pode-se ter uma idéia dos resultados a serem obtidos para outras quantidades de vermiculita, para essa mesma quantidade de látex e fibras. 


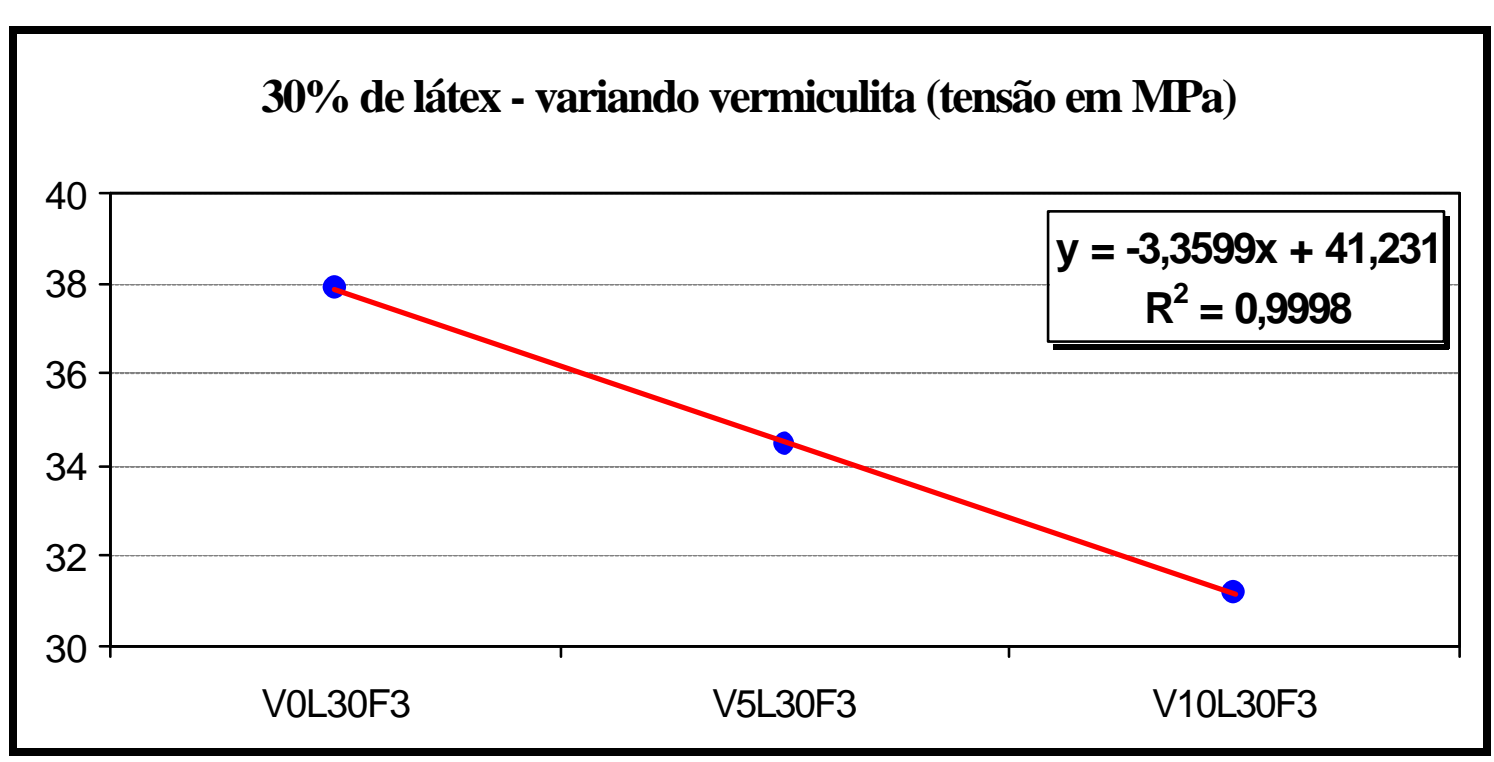

Figura 4.11 - Influência da vermiculita (30\% de látex e 3\% de fibra de PVA)

Desta forma, ao se utilizar, por exemplo, uma mistura com $15 \%$ de vermiculita (ainda não moldada), que seria moldada e ensaiada da mesma forma, com o mesmo cimento, poderia se esperar uma resistência cujo valor seria de, aproximadamente, 28MPa. Neste caso, o coeficiente de correlação $R^{2}$ vale 0,9998 , praticamente igual a 1 , sendo assim a reta pode ser avaliada como bastante precisa e conclui-se que o comportamento da vermiculita é praticamente linear quando se têm acréscimos de 5\% do produto e ao se utilizar 30\% de látex e 3\% de fibra de PVA.

Para comprovar a consistência dos resultados apresentados por essa equação, utilizou-se um traço já moldado com 25\% de vermiculita, 30\% de látex e 3\% de fibras de PVA (V25L30F3). Utilizando-se a equação obteve-se uma resistência de 21,07MPa, ao passo que a resistência média à compressão de 4 corpos-de-prova moldados com esse mesmo traço foi de 21,64MPa, o que equivale a uma diferença de, aproximadamente, $2,5 \%$, diferença bastante pequena já que essa mesma diferença poderia, inclusive, ser obtida numa nova moldagem realizada no mesmo laboratório e com as mesmas condições, o que leva a crer que a equação é consistente e, portanto, pode ser utilizada neste caso.

Doravante, cabe ressaltar que ao se acrescentar maiores quantidades de vermiculita, como é o caso dessa mistura com $25 \%$ do material, tem-se problema com a trabalhabilidade da mistura, em razão da alta capacidade de retenção de água desse material, e, por diversas vezes, torna-se necessária a utilização de superplastificantes. 


\subsubsection{Resistência à tração por compressão diametral}

Neste capítulo serão apresentados os resultados referentes aos ensaios de tração por compressão diametral. Inicialmente, mostrar-se-á um traço com os resultados dos 4 corpos-de-prova e a média entre estes resultados, para verificar a variação dos resultados entre os corpos-de-prova.

Os resultados apresentados na Tabela 4.2 correspondem ao traço V5L30F3.

Tabela 4.2 - Resultados dos CPs para o traço V5L30F3 - tração

\begin{tabular}{||c|c|c|c||}
\hline V5L30F3 & $\begin{array}{c}\text { Resistência à } \\
\text { compressão (MPa) }\end{array}$ & $\begin{array}{c}\text { Média dos 4 } \\
\text { CPs (MPa) }\end{array}$ & $\begin{array}{c}\text { Desvio } \\
\text { padrão da } \\
\text { média }\end{array}$ \\
\hline $\mathbf{1}^{\mathbf{0}} \mathbf{C P}$ & 4,33 & \multirow{2}{*}{4,10} & \multirow{2}{*}{0,18} \\
\cline { 1 - 2 } $\mathbf{2}^{\mathbf{0}} \mathbf{C P}$ & 4,01 & & \\
\cline { 1 - 2 } $\mathbf{3}^{\mathbf{0}} \mathbf{C P}$ & 3,92 & & \\
\hline $\mathbf{4}^{\mathbf{0}} \mathbf{C P}$ & 4,14 & \\
\hline
\end{tabular}

Calculada a média dos 4 corpos-de-prova e o respectivo desvio padrão das amostras, basta calcular a nova média levando em conta o desvio padrão, por meio de aplicação do critério de Chauvenet. Verificoutse, neste caso, que a dispersão entre os valores de resistência à tração por compressão diametral dos 4 corpos-de-prova era muito pequena. Dessa forma, a média será realmente igual a 4,10MPa, valor este que será considerado como a resistência média à tração por compressão diametral do traço V5L30F3. Os cálculos das resistências à tração por compressão diametral dos outros traços foram calculados da mesma forma e as comparações dos resultados de todos os traços são apresentadas na seqüência.

Na Figura 4.12, pode-se observar um gráfico comparativo das tensões máximas de tração para cada traço ao se utilizar fibras de PVA ou de vidro. 


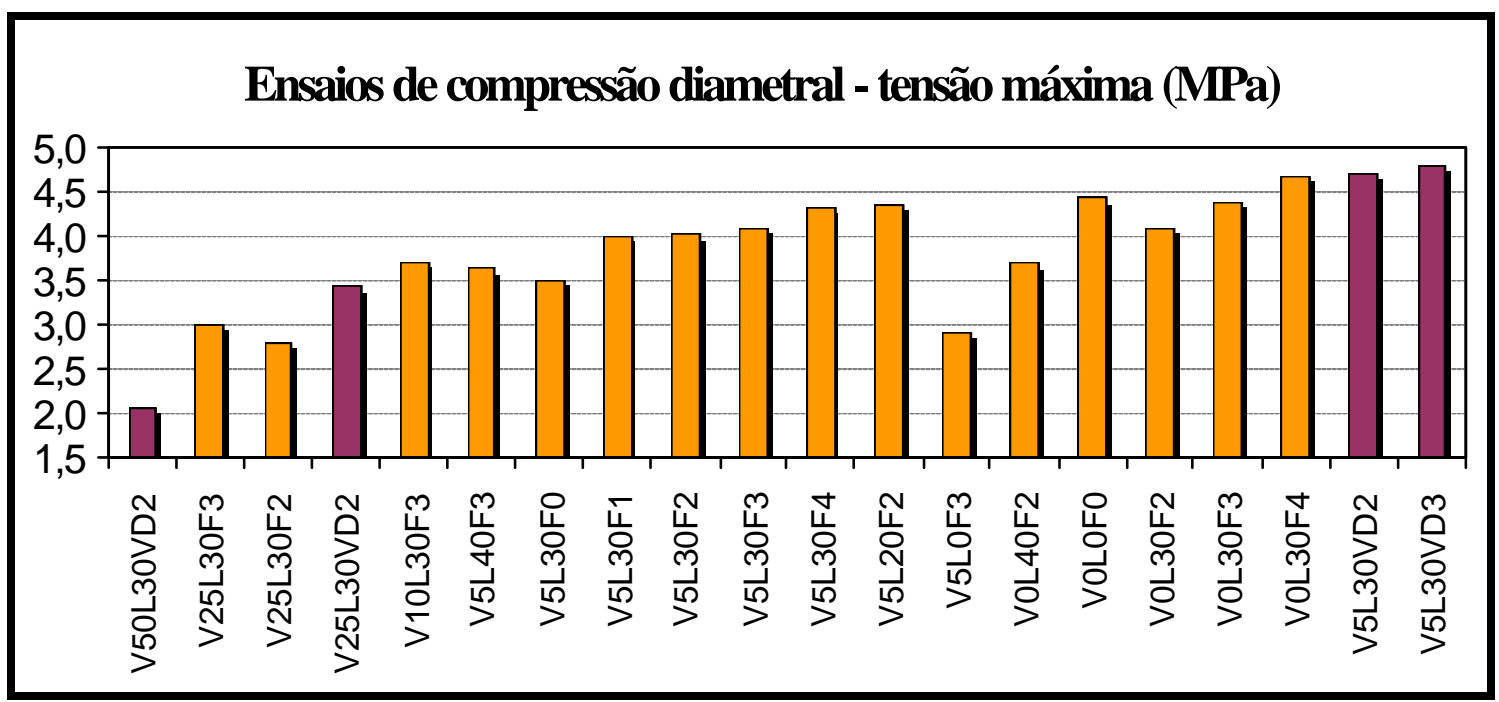

Figura 4.12 - Gráfico comparativo das tensões para ensaio de compressão diametral

Fazendo-se uma análise dos resultados deste tipo de ensaio (Figura 4.12) pode-se notar claramente a influência da vermiculita em cada mistura. À medida que se acrescenta mais vermiculita à mistura, nota-se que a resistência à tração dos corpos-deprova diminui. Em geral, também se pode notar no gráfico que o acréscimo de fibras à mistura acarreta ganho de resistência ao corpo-de-prova, sobretudo nos casos em que se utiliza fibra de vidro. Com relação ao látex, nota-se que a adição do produto nos traços em questão tem proporcionado queda nos valores das resistências, sobretudo quando se utiliza uma taxa de $40 \%$ deste produto. Nota-se também, na Figura 4.12, que a mistura de traço V5L0F3 apresenta um resultado muito estranho, bastante divergente dos demais.

Para melhor avaliação dos resultados deste tipo de ensaio, propõe-se, na sequiência, a utilização de gráficos com menor número de traços a serem avaliados, fixando a quantidade de um ou mais materiais e verificando a influência da variação das quantidades de cada um deles.

Utilizando-se maior quantidade de vermiculita (Figura 4.13), a tendência é de se diminuir a resistência à tração por compressão diametral do corpo-de-prova, como se pode notar, sobretudo, no primeiro traço destacado no gráfico (V50L30VD2).

Observando-se as três últimas misturas em que se utiliza fibra de PVA (3\%) e nas quais a quantidade de látex é mantida constante (30\%), pode-se notar que a cada $5 \%$ de vermiculita que se acrescenta tem-se uma diminuição da resistência à tração de, 
aproximadamente, $8 \%$. Entretanto, ao se observar apenas a $2^{\mathrm{a}}$ e $4^{\mathrm{a}}$ barras do gráfico da Figura 4.13, correspondentes aos traços V25L30F3 e V10L30F3, nota-se que mesmo sendo o acréscimo de vermiculita de $15 \%$, portanto bastante superior aos acréscimos que temos tratado, a diminuição da resistência dos corpos com $25 \%$ de vermiculita em relação à daqueles com $10 \%$ do mesmo material é de apenas $18 \%$, quando se esperava algo bem próximo de $25 \%$ se fossemos avaliar como anteriormente.

Ao se comparar a $2^{\mathrm{a}}$ e $3^{\mathrm{a}}$ barras da Figura 4.13, nota-se que mesmo utilizando uma quantidade menor de fibras em massa, os corpos moldados com o $3^{\circ}$ traço apresentaram maior resistência à tração, o que mostra a maior resistência à tração atribuída pela utilização de fibra de vidro.

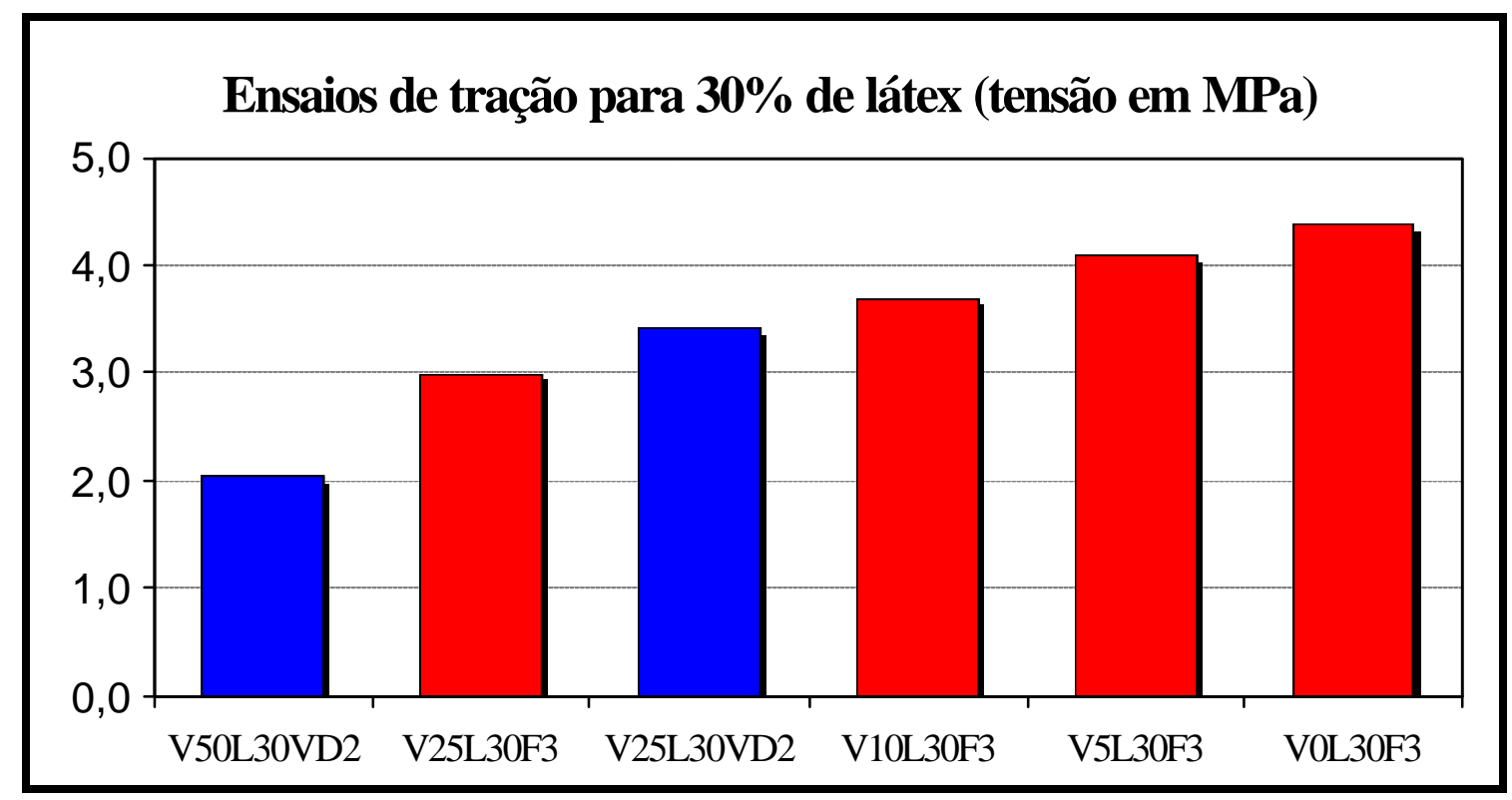

Figura 4.13 - Gráfico das tensões para ensaio de compressão diametral (látex constante)

Na seqüência, fixar-se-á a quantidade de vermiculita em $0 \%$ ou $5 \%$ e verificar-seá a influência de cada um dos outros materiais nas misturas.

Ao se comparar as duas primeiras misturas da Figura 4.14 (V0L40F2 e V0L30F2), variando apenas o látex, pode-se notar a influência do acréscimo do produto na diminuição da resistência do corpo-de-prova à tração, sendo que a diminuição do valor, neste caso, alcança aproximadamente $10 \%$ ao se acrescentar $10 \%$ de látex. Na Figura 4.14, também se apresenta a argamassa simples (VOLOF0) como referência e se pode notar que sua resistência é nitidamente superior às demais, sendo seu valor 
praticamente $8 \%$ superior ao valor da segunda mistura (VOL30F2), isto é, mesmo em se acrescentando uma quantidade de $30 \%$ de látex, o que implicaria numa acentuada queda de resistência à tração, verifica-se que essa queda pouco ocorreu devido ao acréscimo de fibras de PVA. Deve-se relatar, ainda, que essa argamassa simples sofre ruptura brusca (frágil) e é pouco macia, tornando-se inadequada para a utilização como almofada de apoio, sendo seu resultado utilizado apenas para comparação com os dos demais traços, a fim de se moldar corpos cujos traços possuam resistência de valor considerado razoável (muitas vezes até maior que o da argamassa simples), com menor dureza, facilidade de moldagem e adequado para a utilização como almofada de apoio.

Ressalta-se, ainda, que a resistência possa ter caído em função da água presente no látex. Para saber se realmente foi isso que aconteceu deveria ter sido realizado ensaio de ponto de saturação.

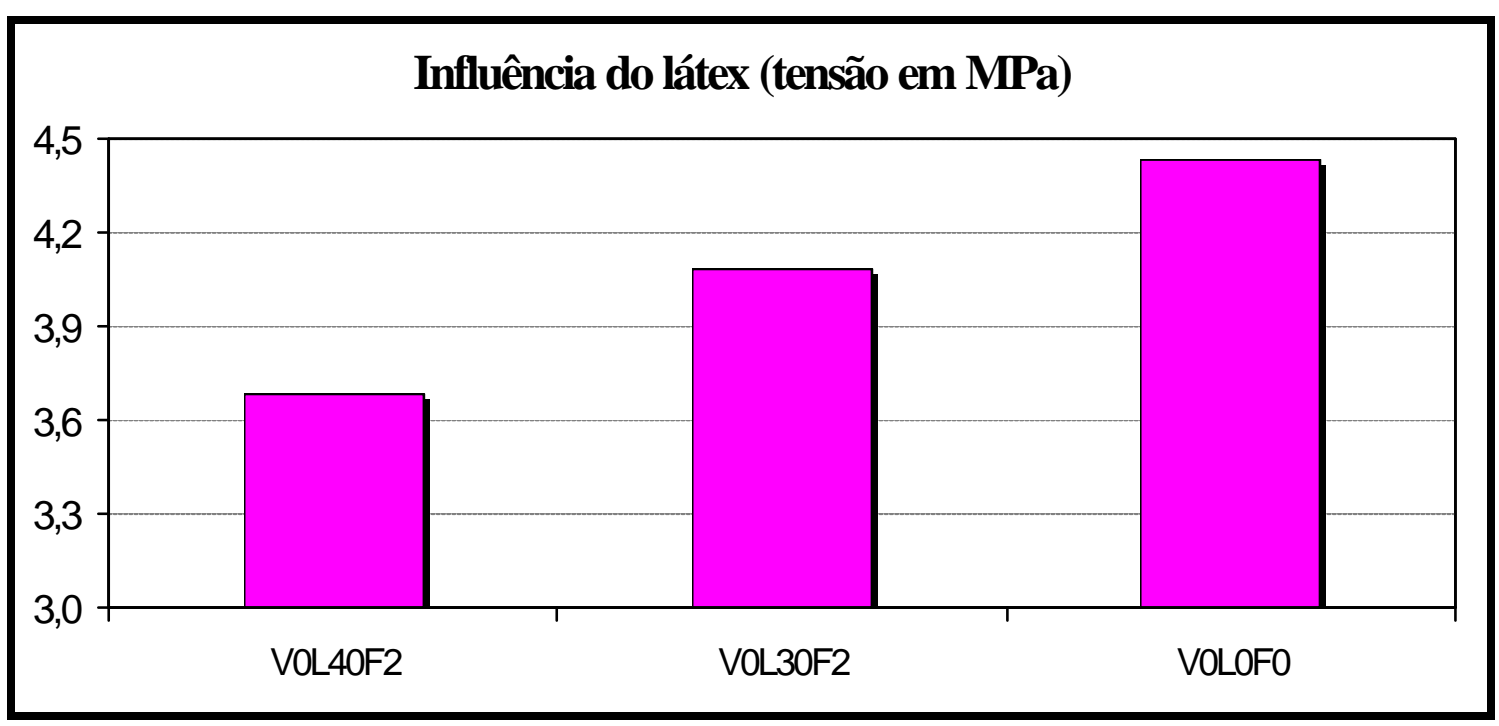

Figura 4.14 - Gráfico das tensões para ensaio de compressão diametral (variando o látex e sem vermiculita)

Para melhor constatar a influência da fibra de PVA para os traços dos corpos-deprova sem vermiculita, optou-se por se construir uma reta mostrando uma equação aproximada das quantidades de fibras de PVA e, a partir dessa equação, pode-se ter uma idéia dos resultados a serem obtidos para outras quantidades de fibra, para essa mesma quantidade de látex e sem que se utilize vermiculita. Poder-se-ia utilizar, por exemplo, uma taxa de fibra de 2,5\% para verificação dos resultados. O coeficiente de correlação $\mathrm{R}^{2}$ é igual a 0,9999 , praticamente igual a1; sendo assim, pode-se dizer que os valores 
obtidos realmente formam uma reta crescente ao se acrescentar $1 \%$ de fibra a cada novo traço.

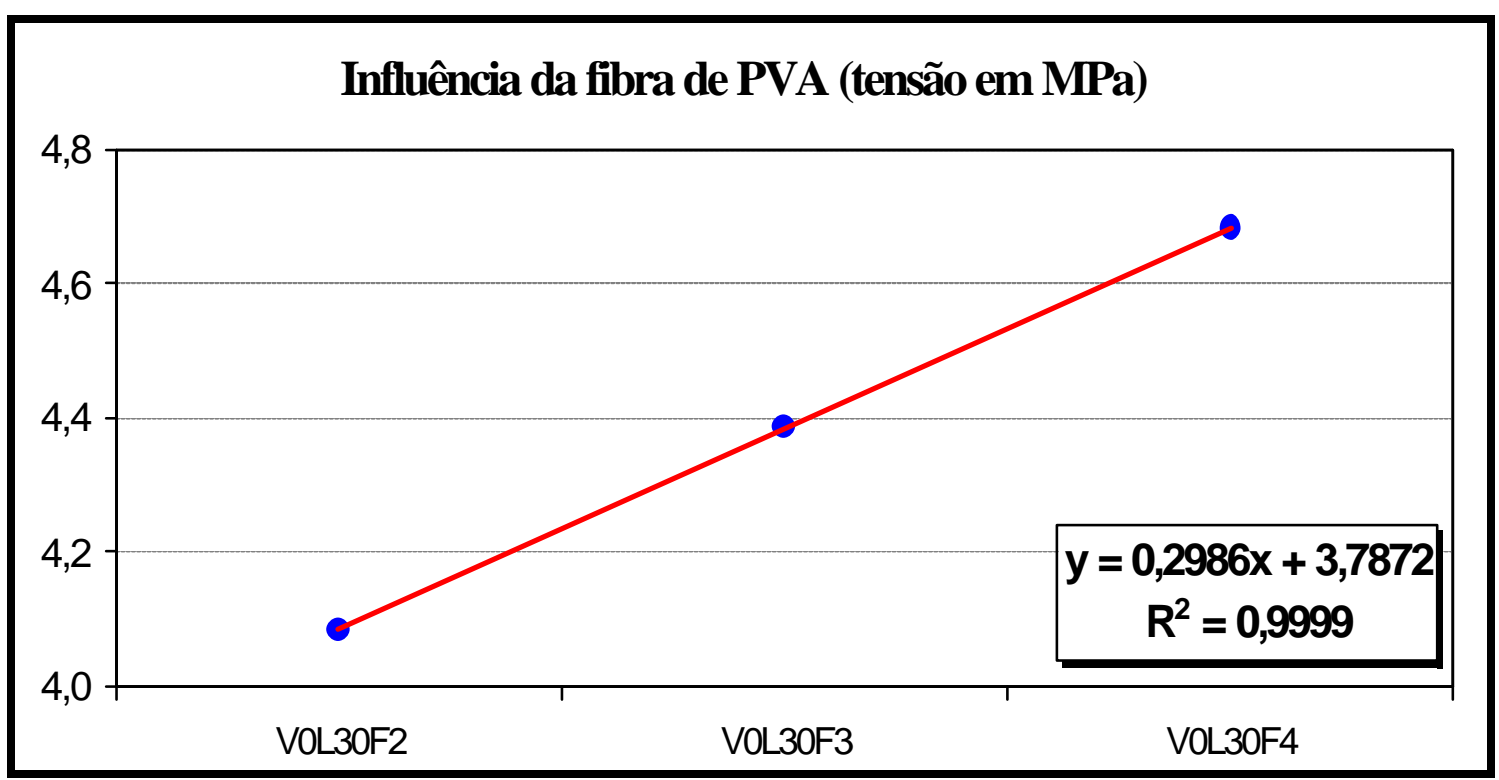

Figura 4.15 - Influência da fibra de PVA (sem vermiculita e 30\% de látex)

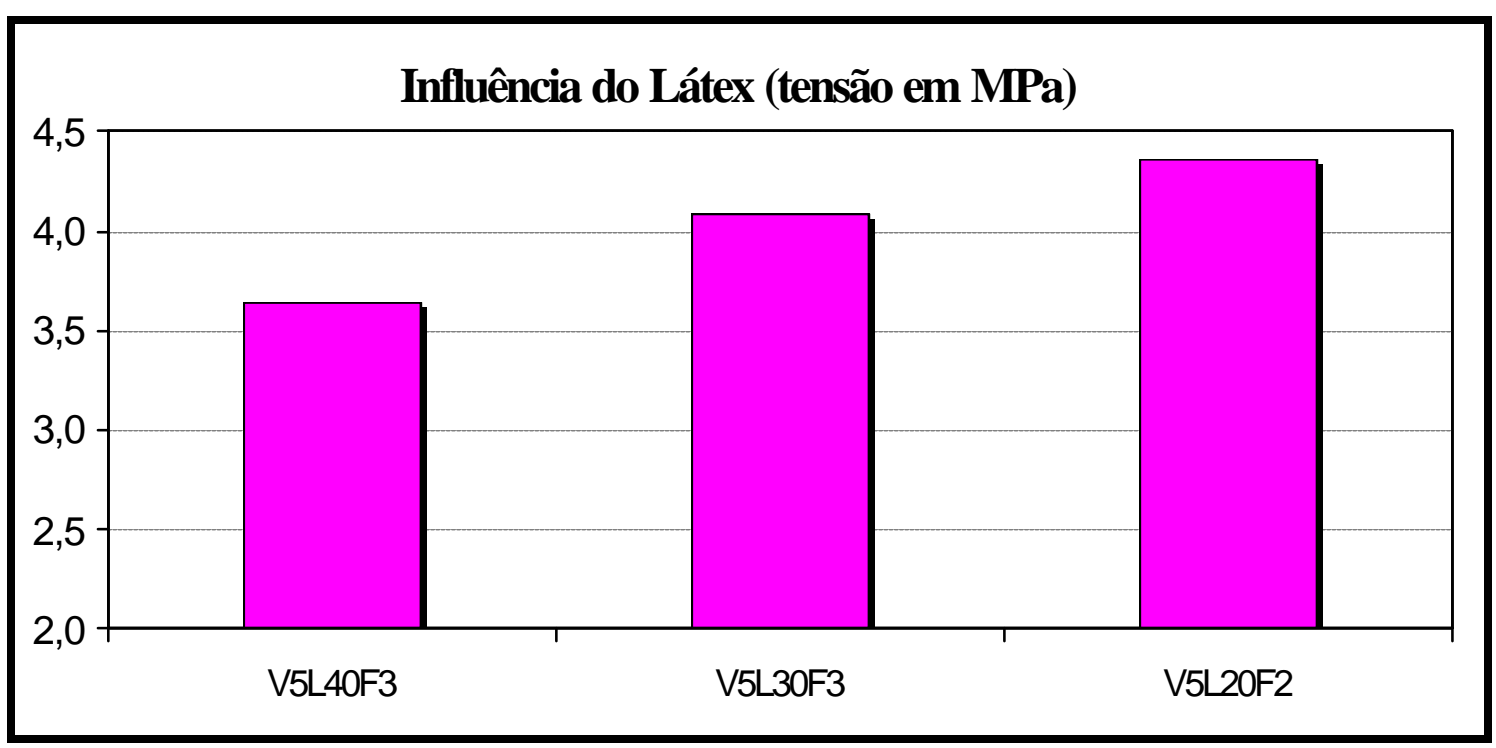

Figura 4.16 - Ensaio com 5\% de vermiculita e fibra de PVA (variando látex)

Ao se comparar as misturas da Figura 4.16, pode-se notar a influência do acréscimo de látex na diminuição da resistência dos corpos-de-prova à tração por compressão diametral, sendo que a diminuição do valor da resistência, neste caso, alcança maiores valores percentuais quando se trata de misturas com maiores quantidades de látex. 
Há também uma mistura com quantidade distinta de fibra de PVA (2\%), contudo esse traço é bastante conveniente para a comparação que vem sendo realizada neste momento, pois mostra o acréscimo na resistência à tração dos corpos-de-prova moldados com esse traço se comparados aos corpos-de-prova moldados no traço V5L30F3, por exemplo. Nota-se que, mesmo possuindo maior quantidade de fibra que, como já vimos, promove maior resistência à tração, a presença do látex atribui aos corpos-de-prova com esse traço uma resistência inferior àquela obtida utilizando apenas $20 \%$ de látex.

Para melhor constatar a influência da fibra de PVA para os traços dos corpos-deprova com pequena quantidade de vermiculita (5\%), optou-se por se construir uma reta mostrando uma equação aproximada das quantidades de fibras de PVA (Figura 4.17). Neste caso, o coeficiente de correlação $\mathrm{R}^{2}$ é igual a 0,8135 (aproximadamente $82 \%$ ), a aproximação da reta com relação aos pontos é pior que em todos os outros casos até aqui estudados, pois naqueles casos $\mathrm{R}^{2}$ tinha valores muito próximos de 1 .

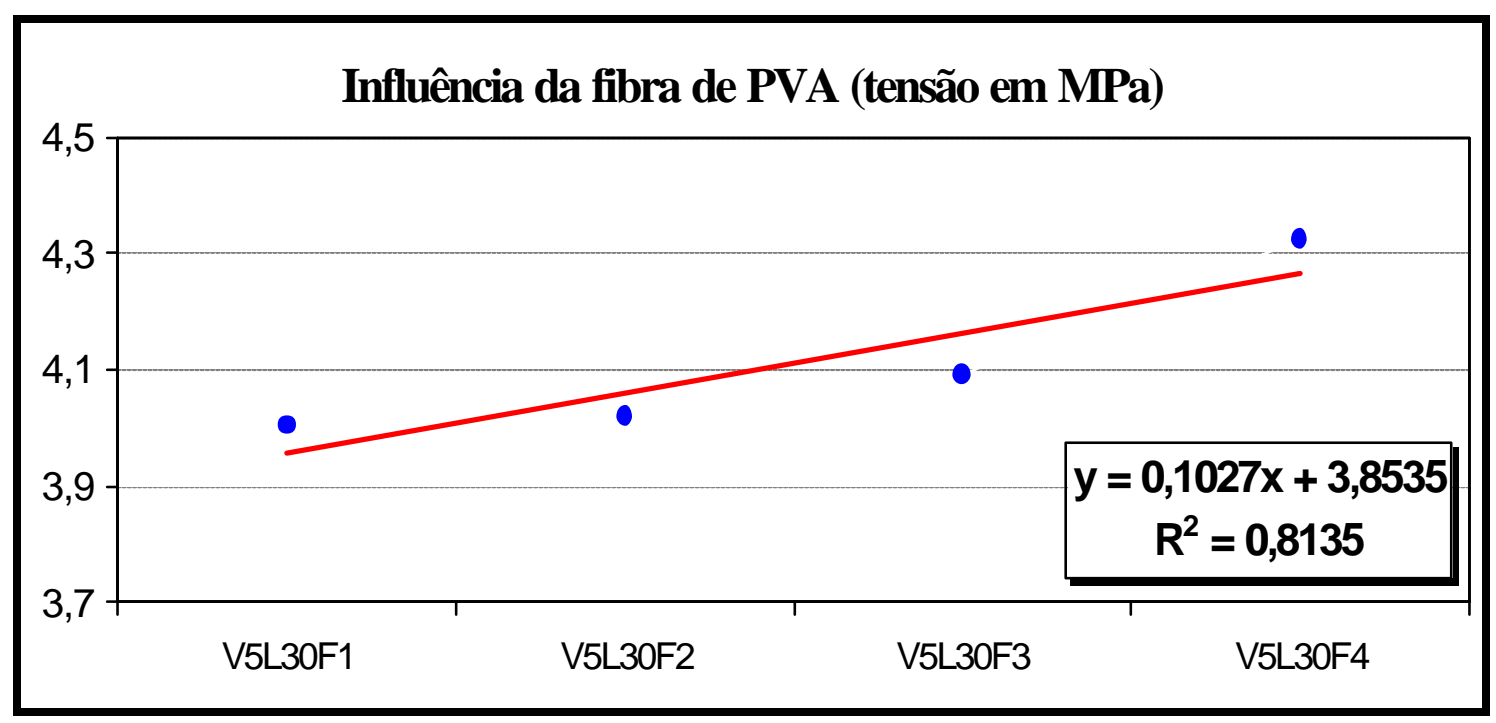

Figura 4.17 - Influência da fibra de PVA (5\% de vermiculita e 30\% de látex)

Ao se comparar as fibras de PVA e vidro para misturas com 5\% de vermiculita, conforme pode ser visto na Figura 4.18, pode-se notar que os valores das resistências para as misturas utilizando fibra de vidro são superiores aos valores para as mesmas misturas ao se utilizar fibra de PVA. 
Para os dois traços especificados na Figura 4.18, o acréscimo percentual em razão da utilização de fibra de vidro em substituição à de PVA é de, aproximadamente, $17 \%$ ao passo que para os ensaios de compressão simples essa diferença em razão da substituição da fibra variava entre $2,75 \%$ para misturas com menos fibra e 2,10\% para misturas com maior quantidade de fibra. Conclui-se que a utilização da fibra de vidro promove grandes acréscimos na resistência à tração, acréscimos consideravelmente maiores que aqueles que a mesma fibra promove quando se trata de resistência à compressão axial.

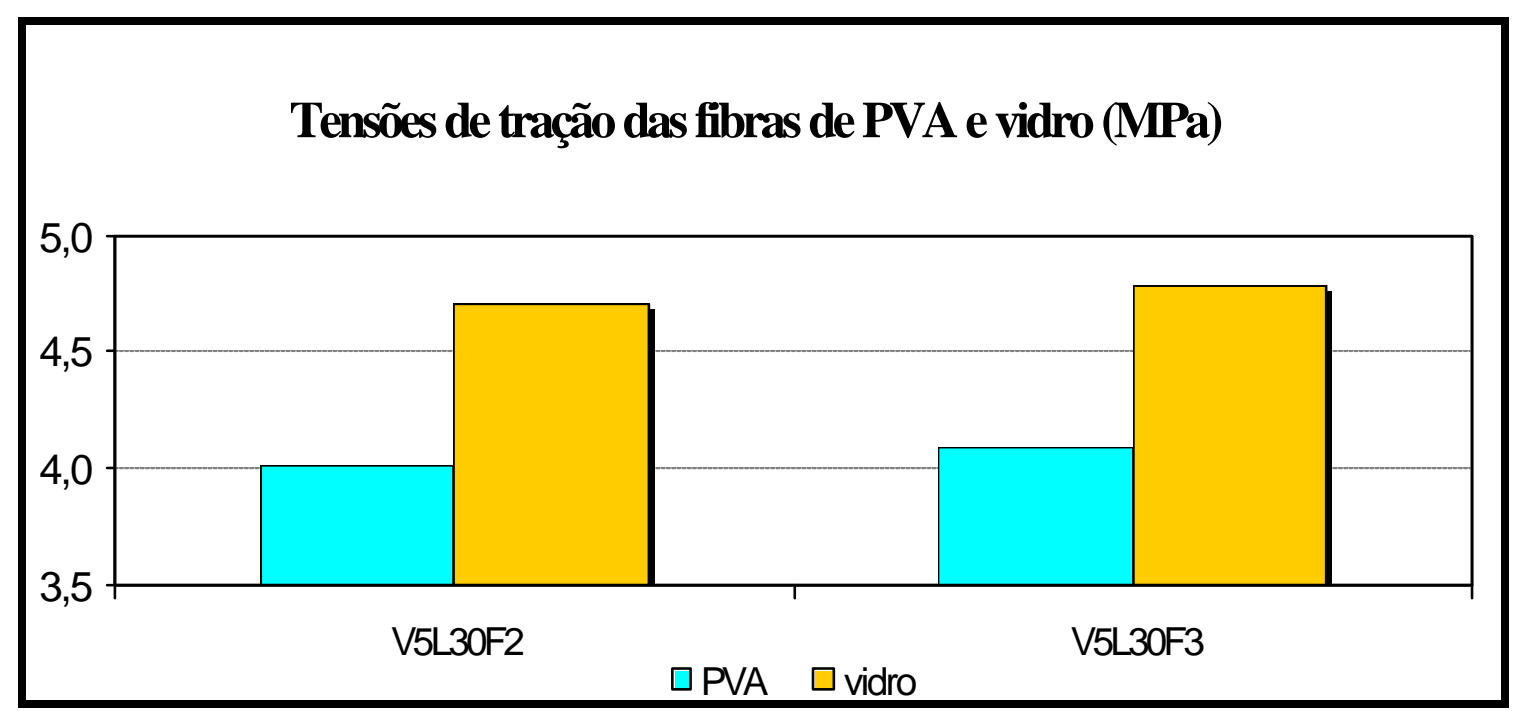

Figura 4.18 - Comparação entre fibra de PVA e vidro (5\% de vermiculita)

Na seqüência avaliar-se-ão resultados de corpos-de-prova com maior quantidade de vermiculita (25\% do material).

Comparando-se inicialmente as duas primeiras misturas da Figura 4.19, ambas utilizando fibra de PVA (V25L30F3 e V25L30F2), nota-se novamente a influência da fibra de PVA no acréscimo de resistência à tração dos corpos-de-prova. O simples acréscimo de $1 \%$ de fibra de PVA, promoveu um aumento de $7,2 \%$ na resistência à tração dos corpos. Entretanto, ao se comparar misturas com as mesmas quantidades de vermiculita $(25 \%)$ e látex $(30 \%)$ e substituindo a fibra de PVA por fibra de vidro (2\% em massa), obtém-se um acréscimo de quase $23 \%$ na resistência à tração.

Avaliando-se o mesmo caso com relação à resistência à compressão (axial) essa diferença cai para algo em torno de $12 \%$. Independente da quantidade de vermiculita, novamente fica claro que o acréscimo de resistência proporcionado pela substituição da 
fibra de PVA pela de vidro é mais relevante quando se trata de resistência de corpos-deprova cilíndricos à tração.

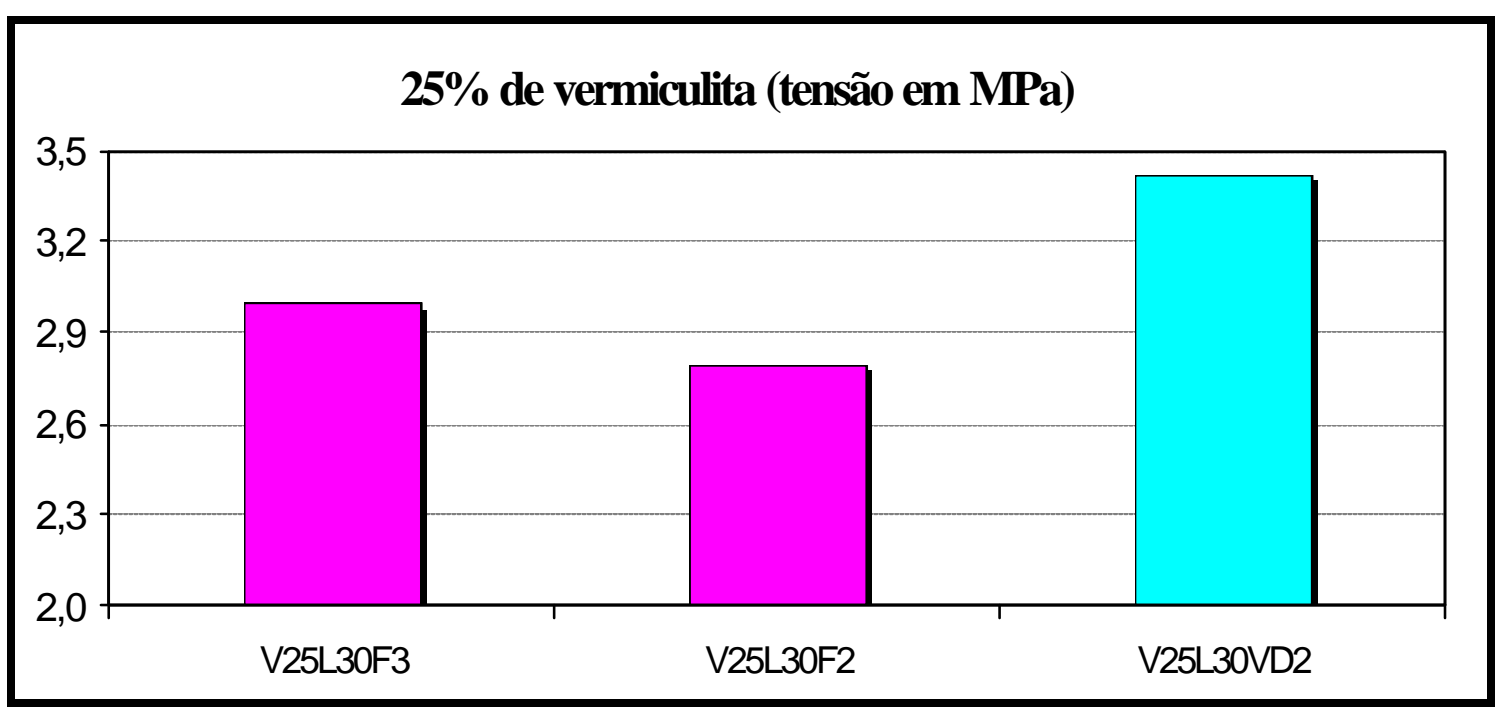

Figura 4.19 - Ensaio de compressão diametral (25\% de vermiculita e 30\% de látex)

Na Figura 4.20 (misturas sem látex), pode-se verificar que ao se utilizar uma argamassa simples (V0L0F0) se obtém uma resistência à tração maior que nos casos em que se utiliza vermiculita e fibra de PVA, como é o caso da outra mistura tratada no gráfico da mesma figura (V5L0F3).

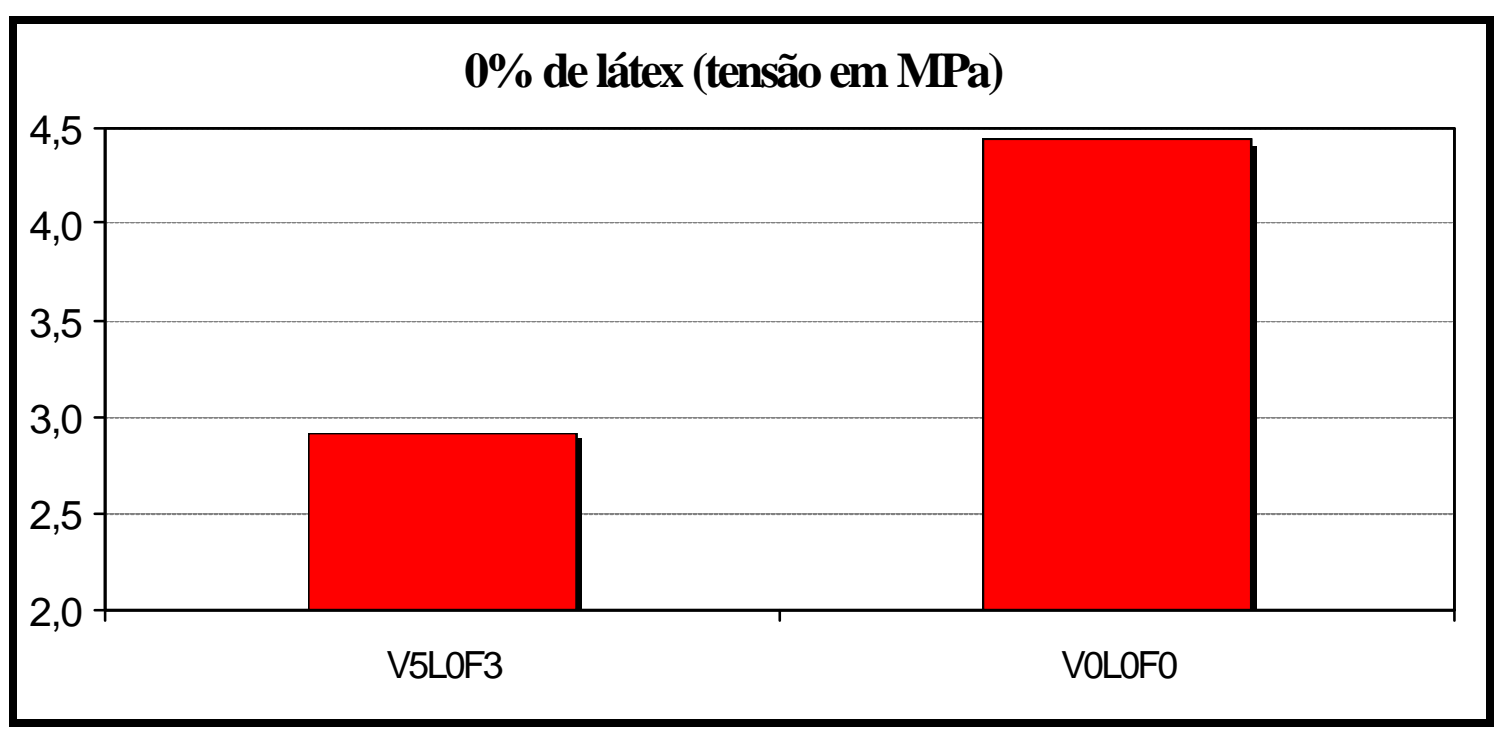

Figura 4.20 - Ensaio de compressão diametral (sem látex) 
O acréscimo de $5 \%$ de vermiculita e $3 \%$ de fibra de PVA promoveu um traço cuja resistência à tração dos corpos-de-prova diminuiu cerca de 34\%. Todavia, a argamassa simples (VOLOF0) sofre ruptura brusca e é pouco macia, tornando-se inadequada para a utilização como almofada de apoio, sendo seu resultado utilizado apenas para comparação com os dos demais traços.

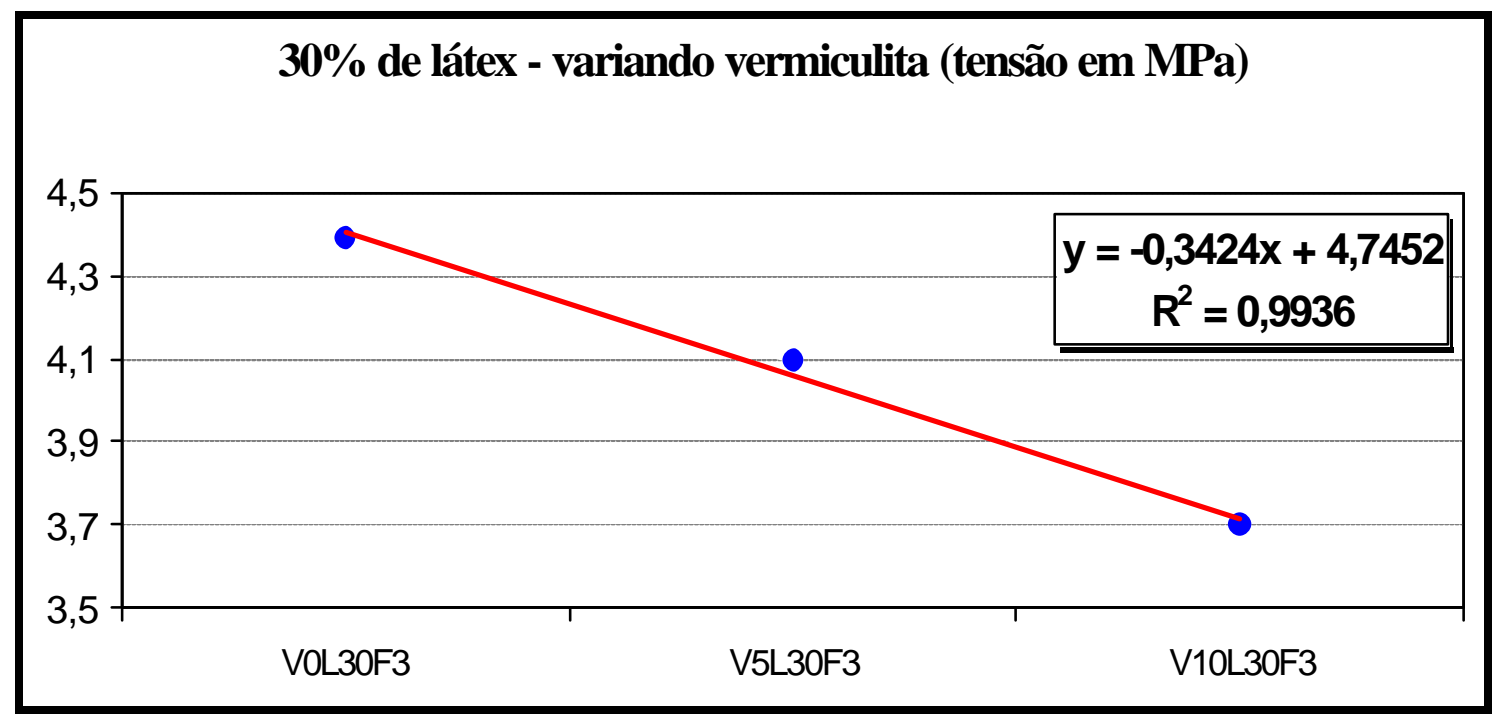

Figura 4.21 - Influência da vermiculita (30\% de látex e 3\% de fibra de PVA)

Para melhor constatar a influência da vermiculita para os traços dos corpos-deprova com quantidade de fibra de PVA fixada em 3\%, construiu-se uma reta mostrando uma equação aproximada da quantidade de vermiculita (Figura 4.21) e, a partir dessa equação, pode-se ter uma idéia dos resultados a serem obtidos para outras quantidades de vermiculita, para essa mesma quantidade de látex e fibras.

Desta forma, ao se utilizar, por exemplo, uma mistura com $15 \%$ de vermiculita (ainda não moldada), que seria moldada e ensaiada da mesma forma, com o mesmo cimento, poderia se esperar uma resistência cujo valor seria de, aproximadamente, 3,4MPa. Neste caso, o coeficiente de correlação $\mathrm{R}^{2}$ vale 0,9936 , valor muito próximo de 1 , portanto a precisão da reta que representa a regressão pode ser considerada muito boa. 


\subsubsection{Módulo de elasticidade}

Neste capítulo serão apresentados os resultados referentes aos ensaios de compressão para determinação do módulo de elasticidade. Inicialmente, mostrar-se-á um traço com os resultados dos 3 corpos-de-prova e a média entre estes resultados, para verificar a variação dos resultados entre os corpos-de-prova. Os resultados apresentados na Tabela 4.3 correspondem ao traço V5L30F2.

Tabela 4.3 - Resultados dos CPs para o traço V5L30VD2 - cálculo do módulo de elasticidade

\begin{tabular}{||c|c|c|c|c|c|c|c||}
\hline \hline \multirow{2}{*}{$\begin{array}{c}\text { Tensão } \\
\text { (MPa) }\end{array}$} & \multicolumn{3}{|c|}{ Deslocamento (mm) } & \multicolumn{4}{|c||}{ Deformação (mm/mm) } \\
\cline { 2 - 8 } & $\mathbf{1}^{\mathbf{0}} \mathbf{C P}$ & $\mathbf{2}^{\mathbf{}} \mathbf{C P}$ & $\mathbf{3}^{\mathbf{0}} \mathbf{C P}$ & $\mathbf{1}^{\mathbf{}} \mathbf{C P}$ & $\mathbf{2}^{\mathbf{}} \mathbf{C P}$ & $\mathbf{3}^{\mathbf{}} \mathbf{C P}$ & $\begin{array}{c}\text { Média dos } \\
\mathbf{C P s}\end{array}$ \\
\hline $\mathbf{0 , 0 0}$ & 0,000 & 0,000 & 0,000 & 0,0000 & 0,0000 & 0,0000 & $\mathbf{0 , 0 0 0 0}$ \\
\hline $\mathbf{1 , 2 7}$ & 0,005 & 0,006 & 0,007 & 0,0001 & 0,0001 & 0,0001 & $\mathbf{0 , 0 0 0 1}$ \\
\hline $\mathbf{2 , 5 5}$ & 0,009 & 0,010 & 0,011 & 0,0002 & 0,0002 & 0,0002 & $\mathbf{0 , 0 0 0 2}$ \\
\hline $\mathbf{3 , 8 2}$ & 0,013 & 0,014 & 0,015 & 0,0003 & 0,0003 & 0,0003 & $\mathbf{0 , 0 0 0 3}$ \\
\hline $\mathbf{5 , 1 0}$ & 0,018 & 0,019 & 0,019 & 0,0004 & 0,0004 & 0,0004 & $\mathbf{0 , 0 0 0 4}$ \\
\hline $\mathbf{6 , 3 7}$ & 0,023 & 0,024 & 0,025 & 0,0005 & 0,0005 & 0,0005 & $\mathbf{0 , 0 0 0 5}$ \\
\hline $\mathbf{7 , 6 4}$ & 0,028 & 0,029 & 0,029 & 0,0006 & 0,0006 & 0,0006 & $\mathbf{0 , 0 0 0 6}$ \\
\hline $\mathbf{8 , 9 2}$ & 0,033 & 0,033 & 0,034 & 0,0007 & 0,0007 & 0,0007 & $\mathbf{0 , 0 0 0 7}$ \\
\hline $\mathbf{1 0 , 1 9}$ & 0,038 & 0,038 & 0,039 & 0,0008 & 0,0008 & 0,0008 & $\mathbf{0 , 0 0 0 8}$ \\
\hline $\mathbf{1 1 , 4 6}$ & 0,044 & 0,043 & 0,044 & 0,0009 & 0,0009 & 0,0009 & $\mathbf{0 , 0 0 0 9}$ \\
\hline $\mathbf{1 2 , 7 4}$ & 0,049 & 0,049 & 0,049 & 0,0010 & 0,0010 & 0,0010 & $\mathbf{0 , 0 0 1 0}$ \\
\hline $\mathbf{1 4 , 0 1}$ & 0,054 & 0,053 & 0,055 & 0,0011 & 0,0011 & 0,0011 & $\mathbf{0 , 0 0 1 1}$ \\
\hline $\mathbf{1 5 , 2 9}$ & 0,060 & 0,060 & 0,061 & 0,0012 & 0,0012 & 0,0012 & $\mathbf{0 , 0 0 1 2}$ \\
\hline $\mathbf{1 6 , 5 6}$ & 0,066 & 0,065 & 0,067 & 0,0013 & 0,0013 & 0,0013 & $\mathbf{0 , 0 0 1 3}$ \\
\hline $\mathbf{1 7 , 8 3}$ & 0,072 & 0,072 & 0,073 & 0,0014 & 0,0014 & 0,0015 & $\mathbf{0 , 0 0 1 4}$ \\
\hline $\mathbf{1 9 , 1 1}$ & 0,080 & 0,079 & 0,081 & 0,0016 & 0,0016 & 0,0016 & $\mathbf{0 , 0 0 1 6}$ \\
\hline $\mathbf{2 0 , 3 8}$ & 0,087 & 0,086 & 0,088 & 0,0017 & 0,0017 & 0,0018 & $\mathbf{0 , 0 0 1 7}$ \\
\hline $\mathbf{2 1 , 6 6}$ & 0,095 & 0,093 & 0,096 & 0,0019 & 0,0019 & 0,0019 & $\mathbf{0 , 0 0 1 9}$ \\
\hline $\mathbf{2 2 , 9 3}$ & 0,104 & 0,102 & 0,105 & 0,0021 & 0,0020 & 0,0021 & $\mathbf{0 , 0 0 2 1}$ \\
\hline $\mathbf{2 4 , 2 0}$ & 0,112 & 0,109 & 0,115 & 0,0022 & 0,0022 & 0,0023 & $\mathbf{0 , 0 0 2 2}$ \\
\hline $\mathbf{2 5 , 4 8}$ & 0,121 & 0,118 & 0,125 & 0,0024 & 0,0024 & 0,0025 & $\mathbf{0 , 0 0 2 4}$ \\
\hline \hline
\end{tabular}

Obtidos os valores das tensões e das deformações de cada um dos corpos-deprova bem como a média entre estas deformações, constrói-se dois gráficos tensão versus deformação representados nas Figuras 4.22 e 4.23. Na Figura 4.22 pode-se observar o gráfico tensão versus deformação dos 3 CPs e da média entre os CPs para 
verificar a variação entre os resultados apresentados por cada CP. Já a Figura 4.23 mostra apenas a curva tensão versus deformação para a média dos resultados dos CPs, nesta figura também é apresentada uma regressão de $2^{\circ}$ grau dos valores do gráfico, sendo que a variável $b$ da equação, ou seja, o valor que multiplica $x$, representa o módulo de elasticidade tangente.

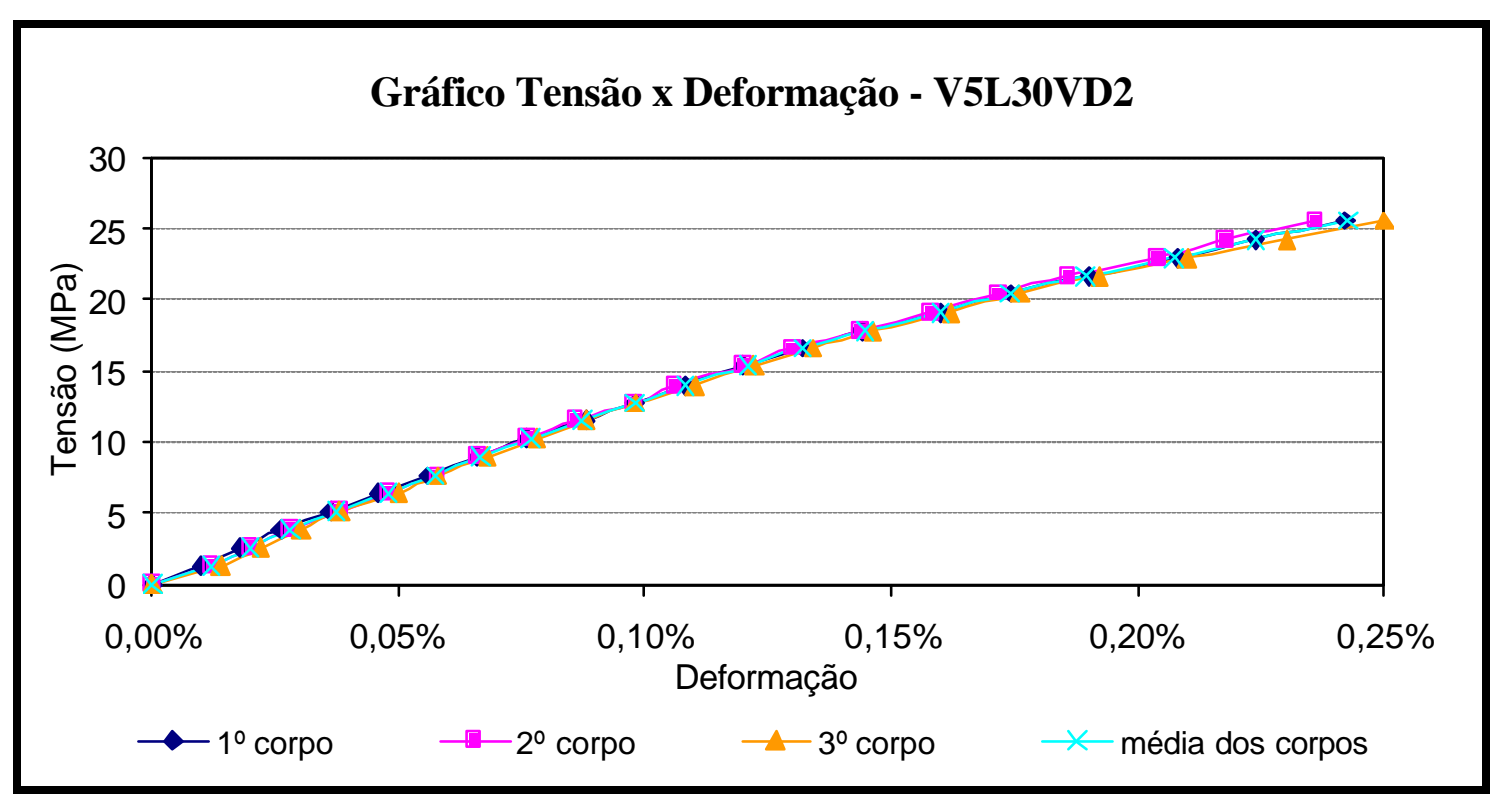

Figura 4.22 - Resultados dos 3 CPs e da média

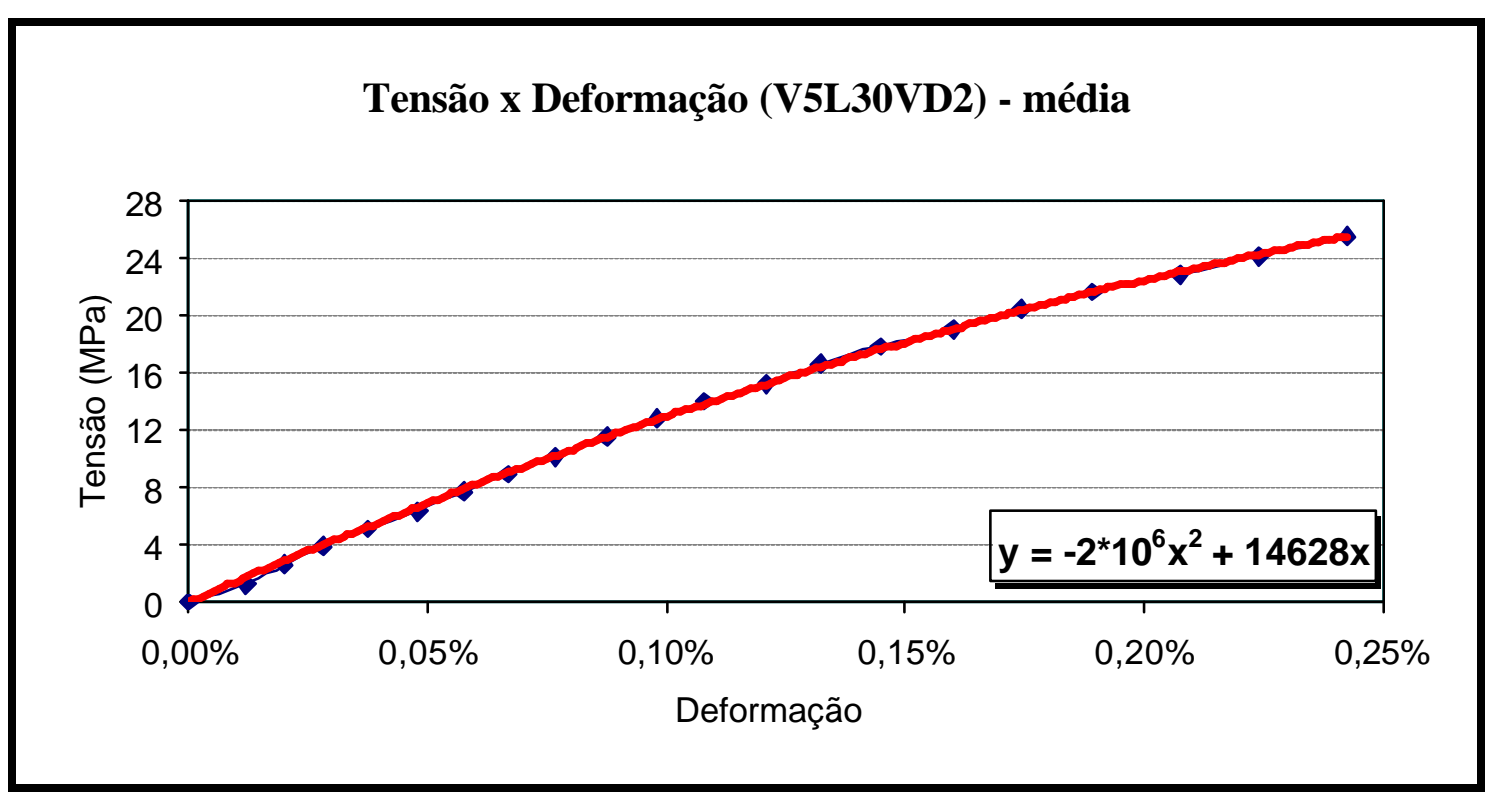

Figura 4.23 - Média dos 3 CPs e regressão para obtenção da elasticidade

Nota-se, pelo gráfico da Figura 4.22, que os valores dos 3 CPs são bastante próximos, em alguns casos são até mesmo idênticos, o que torna válido utilizar apenas 
os valores da média num único gráfico e efetuar uma regressão dos seus valores para a obtenção do módulo de elasticidade tangente (Figura 4.23).

Dessa forma, obtém-se um módulo de elasticidade tangente igual a 14,63GPa para os corpos-de-prova de traço V5L30VD2. Para o cálculo do módulo de elasticidade secante, pegou-se um valor de tensão igual a, aproximadamente, $50 \%$ do valor da tensão máxima aplicada e o seu correspondente valor de deformação na curva da regressão. Lembrando que essa tensão máxima do gráfico não corresponde à tensão máxima de compressão do corpo-de-prova, pois a aplicação da carga era interrompida antes de se atingir a carga máxima para que não houvessem danos nos transdutores.

$\mathrm{O}$ valor correspondente à metade da tensão máxima do gráfico era o de $12,74 \mathrm{MPa}$ e, utilizando-se a equação da regressão, tem-se uma deformação equivalente a $0,1 \%$. Basta calcular a razão tensão/deformação e obtém-se o valor do módulo de elasticidade secante, como na equação 4.1 .

$$
\mathrm{E}_{\mathrm{cs}}=\frac{\sigma}{\varepsilon}=\frac{12,74}{0,00101}=12,61 \mathrm{GPa}
$$

Assim sendo, o valor da elasticidade secante para os corpos-de-prova de traço V5L30F2 é 12,61GPa, o que corresponde a $86 \%$ do valor do módulo de elasticidade tangente.

Os cálculos dos módulos de elasticidade dos outros traços foram calculados da mesma forma e as comparações dos resultados de todos os traços são apresentadas na seqüência.

De posse dos resultados dos valores dos módulos de elasticidade tangente e secante de todos os traços moldados, construiu-se um gráfico comparativo com tais valores, como pode ser visto na Figura 4.24.

Fazendo uma breve análise dos resultados deste tipo de ensaio pode-se notar com clareza a influência da vermiculita em cada traço. À medida que se acrescenta este material ao traço estudado, nota-se que o Módulo de Elasticidade dos corpos-de-prova diminui. Em geral, pode-se notar no gráfico que o acréscimo de fibras acarreta diminuição nos valores de elasticidade. 


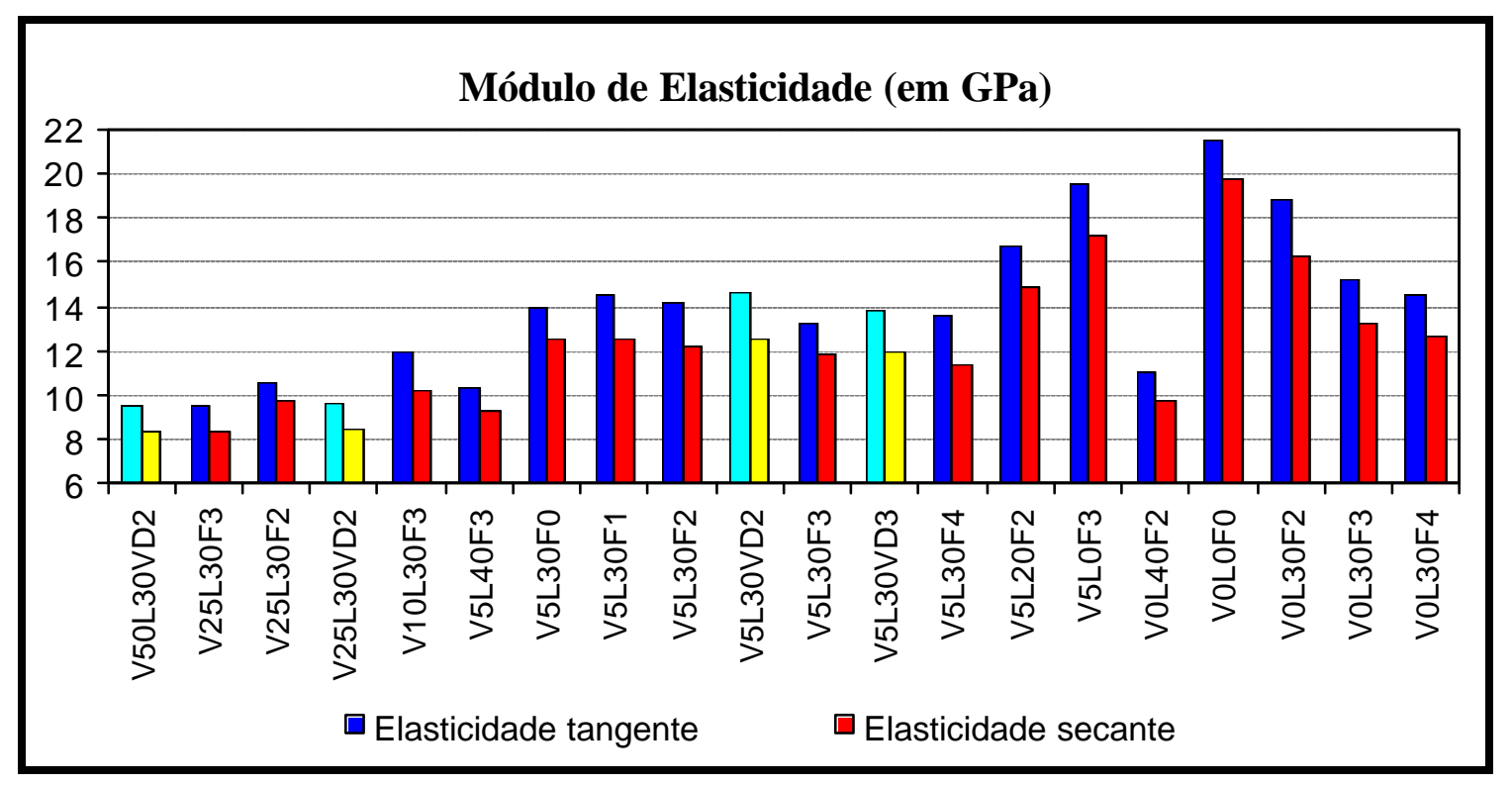

Figura 4.24 - Gráfico comparativo dos Módulos de Elasticidade

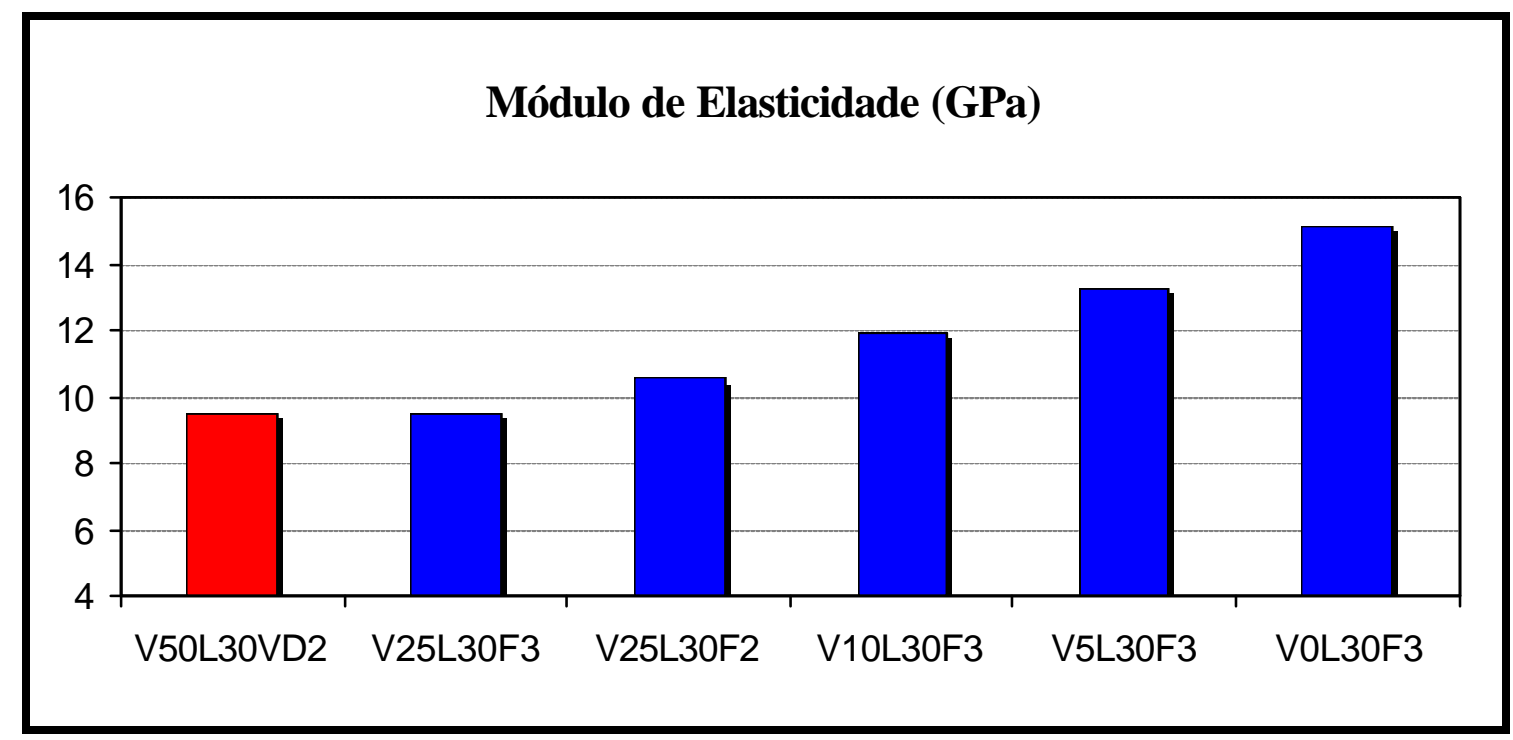

Figura 4.25 - Influência da vermiculita no valor do Módulo de Elasticidade Tangente

Utilizando-se maior quantidade de vermiculita (Figura 4.25), a tendência é de se diminuir o módulo de elasticidade do compósito, como se pode notar, sobretudo, nos dois primeiros traços destacados no gráfico. Todavia, ao se comparar os dois primeiros traços mostrados no mesmo gráfico (V50L30VD2 e V25L30F3, respectivamente), notase que, mesmo possuindo o dobro da quantidade de vermiculita, a primeira mistura possui elasticidade praticamente igual à da segunda mistura, o que mostra que a presença da fibra de vidro acarreta acréscimo no valor do Módulo de Elasticidade. 


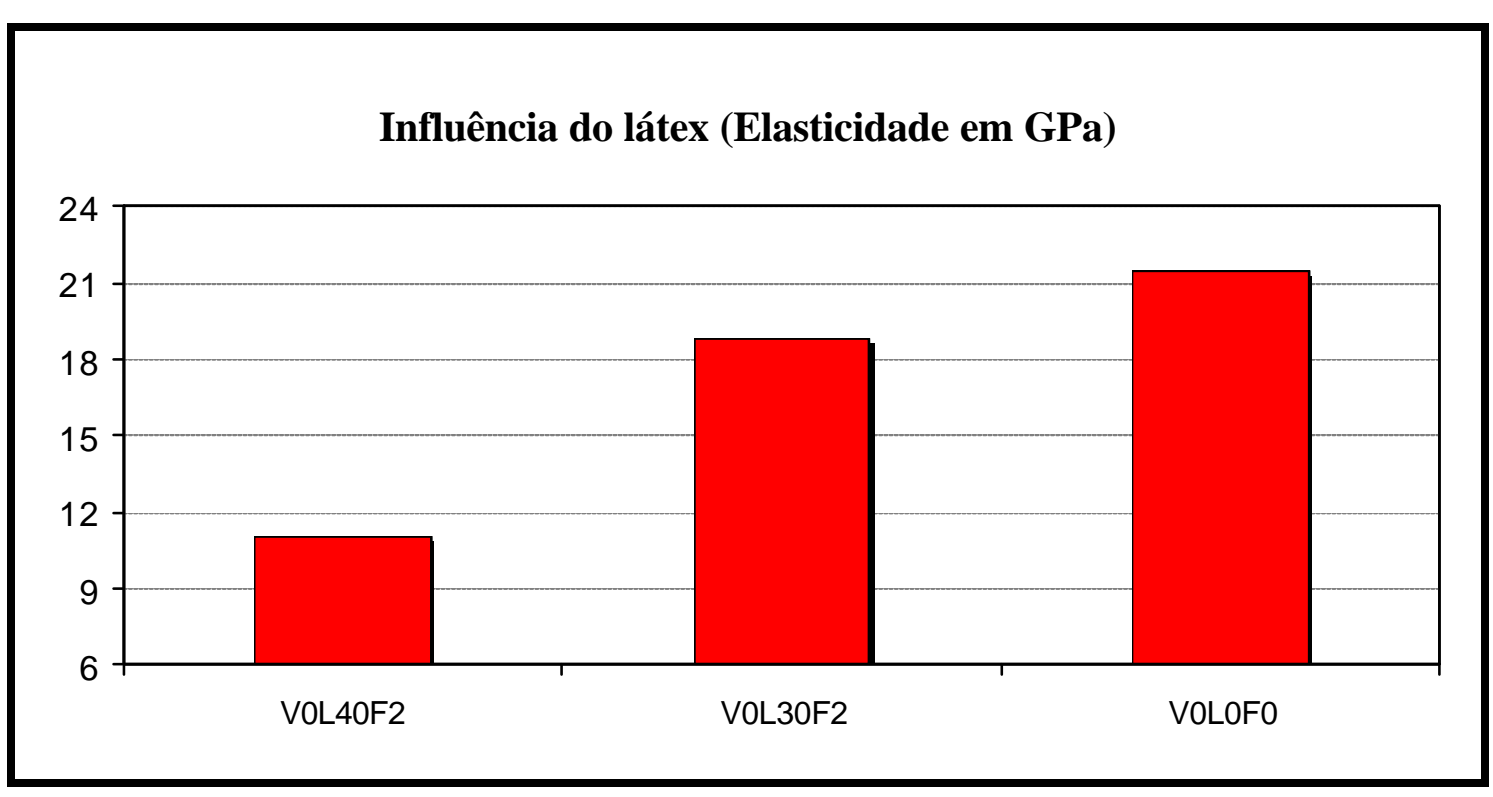

Figura 4.26 - Influência do látex (sem vermiculita)

Ao se comparar as duas primeiras misturas da Figura 4.26 (V0L40F2 e V0L30F2), misturas sem vermiculita e variando apenas o látex, pode-se notar a influência do acréscimo do produto na diminuição do módulo de elasticidade, sendo que a diminuição do valor, neste caso, alcança, aproximadamente, $40 \%$ ao se acrescentar 10\% de látex. Na Figura 4.26, também se apresenta a argamassa simples (VOLOF0) e se pode notar que sua elasticidade é nitidamente superior às demais, sendo seu valor praticamente $10 \%$ superior ao valor da segunda mistura (V0L30F2), isto é, mesmo em se acrescentando uma quantidade de $30 \%$ de látex, o que implicaria numa certa queda de elasticidade, verifica-se que essa queda pouco ocorreu devido ao acréscimo de fibras de PVA.

Ao se comparar as fibras de PVA e vidro para misturas com 5\% de vermiculita, conforme pode ser visto na Figura 4.27, pode-se notar que, geralmente, os valores das elasticidades para as misturas utilizando fibra de vidro são superiores aos valores para estas misturas ao se utilizar fibra de PVA. Para o primeiro traço desta figura, o acréscimo percentual em razão da utilização de fibra de vidro em substituição à de PVA (2\%) é de 3,02\% ao passo que para a outra mistura (3\% de fibra) o acréscimo percentual é maior, sendo de, aproximadamente, $5 \%$. 


\section{Comparação da elasticidade entre fibra de PVA e vidro}

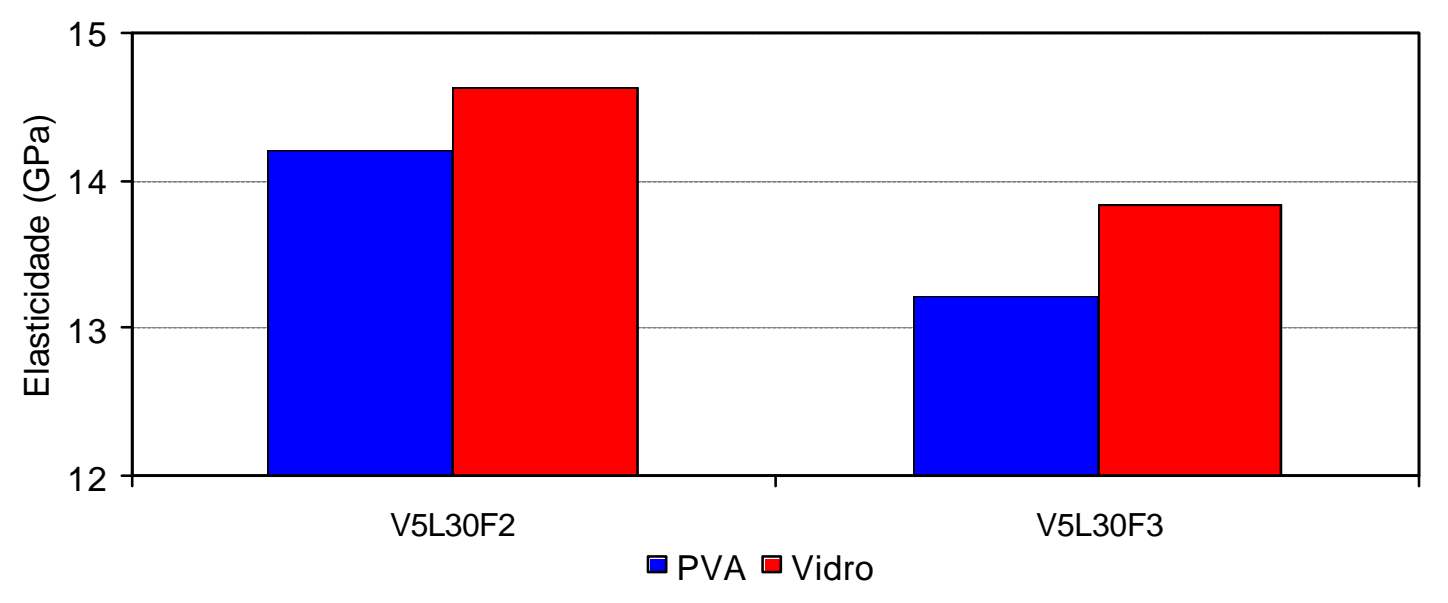

Figura 4.27 - Elasticidade das fibras de PVA e vidro (5\% de vermiculita e 30\% de látex)

Para melhor constatar a influência da vermiculita para os traços dos corpos-deprova com quantidade de fibra de PVA fixada em 3\%, construiu-se, novamente, uma reta mostrando uma equação aproximada da quantidade de vermiculita (Figura 4.28) e, a partir dessa equação, pode-se ter uma idéia dos resultados a serem obtidos para outras quantidades de vermiculita, para essa mesma quantidade de látex e fibras, bem como avaliar a variação da elasticidade a cada acréscimo de $5 \%$ de vermiculita.

Influência da vermiculita na elasticidade tangente (30\% de látex e 3\% de fibra de PVA)

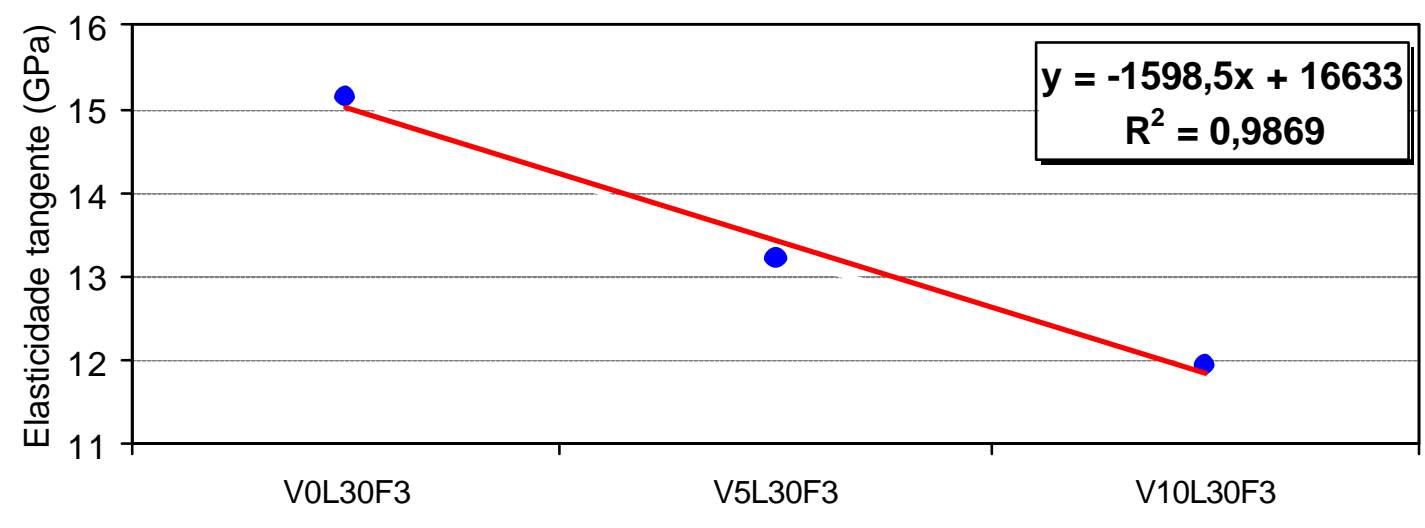

Figura 4.28 - Influência da vermiculita na elasticidade (30\% de látex e 3\% de PVA) 
Desta forma, ao se utilizar, por exemplo, uma mistura com $15 \%$ de vermiculita (ainda não moldada), que seria moldada e ensaiada da mesma forma, com o mesmo cimento, poderia se esperar uma elasticidade cujo valor seria de, aproximadamente, 10,2GPa. Neste caso, o coeficiente de correlação $R^{2}$ vale 0,9869 , valor próximo de 1 , portanto a precisão da reta que representa a regressão pode ser considerada razoavelmente boa.

\subsubsection{Análise das características do material}

Nas Figuras 4.29 e 4.30, pode-se verificar algumas características acerca de 2 traços ensaiados à compressão simples.

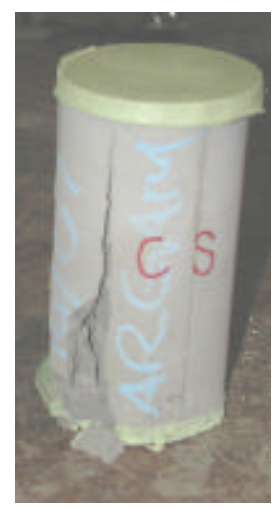

Figura 4.29 - Corpo-de-prova no traço V0L0F0 (argamassa simples) após ensaio

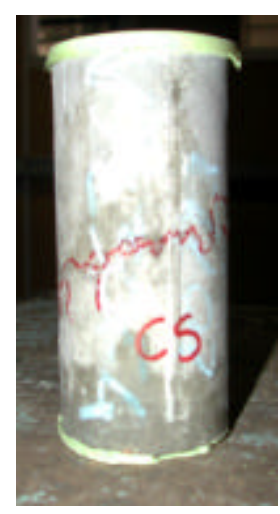

Figura 4.30 - Corpo-de-prova no traço V5L30F4 após ensaio

Analisando-se as Figuras 4.29 e 4.30 pode-se notar claramente a influência da fibra no sentido de evitar grandes fissuras ou lascas no corpo-de-prova quando o mesmo é submetido à compressão axial. A fibra atua interceptando a fissura, evitando a ruptura frágil do corpo-de-prova. Entretanto, também cabe destacar que o capeamento com enxofre utilizado realmente não era a melhor opção a ser utilizada, já que os resultados poderiam ter sido melhores se o corpo tivesse sido retificado, processo mais aconselhável quando se trata de corpos com resistência superior a 30MPa. Essa é uma possível explicação para aquela grande lasca do corpo-de-prova da Figura 4.29.

Nas Figuras 4.31, 4.32 e 4.33 pode-se verificar algumas características acerca de 3 traços ensaiados à tração por compressão diametral. 
Analisando-se as Figuras 4.31, 4.32 e 4.33 pode-se notar claramente a influência da fibra no sentido de evitar grandes fissuras, lascas ou, até mesmo, a ruptura completa do corpo-de-prova quando o mesmo é submetido à tração. Neste caso, em que os corpos-de-prova são submetidos à tração, é ainda mais nítida a ação das fibras na interceptação das fissuras e impedimento da ruptura frágil.

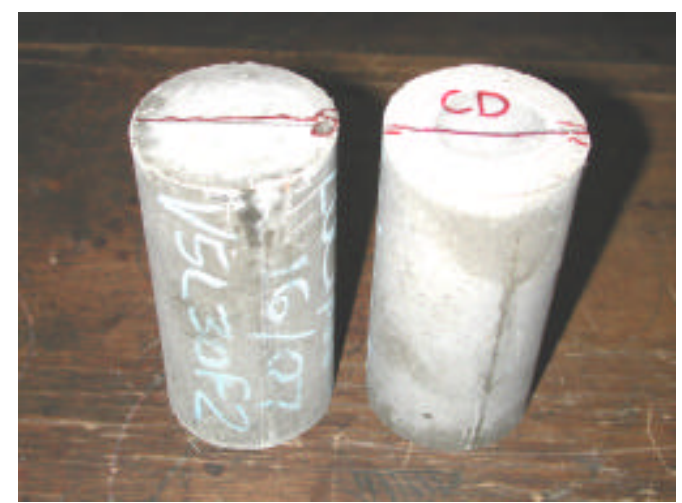

Figura 4.31 - Corpos-de-prova no traço

V5L30F2 após ensaio de tração por compressão diametral

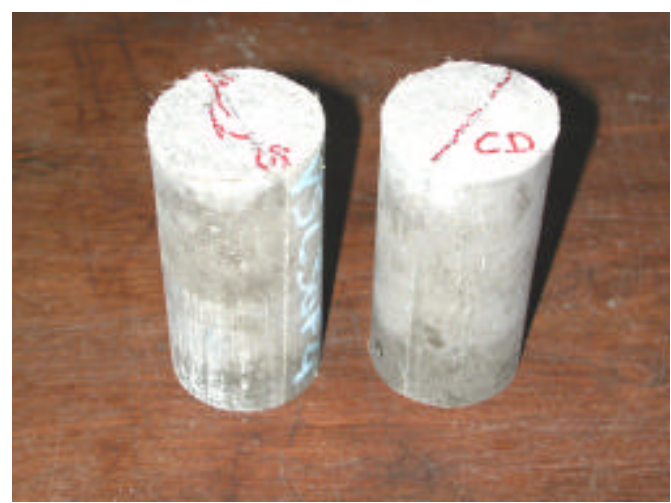

Figura 4.32 - Corpos-de-prova no traço

V5L30F4 após ensaio de tração por compressão diametral

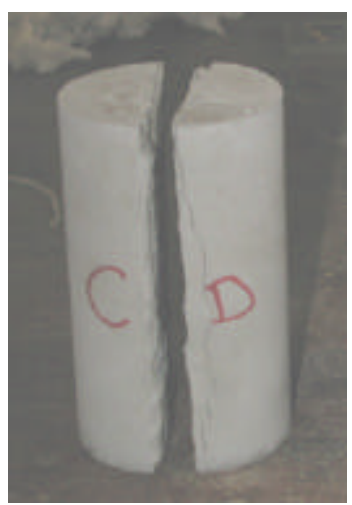

Figura 4.33 - Corpos-de-prova no traço V0L0F0 (argamassa simples) após ensaio de tração por compressão diametral

Com relação aos valores das resistências desses 3 traços em especial, nota-se que a resistência à tração de V0L0F0 é similar à resistência à tração dos corpos de traço V5L30F4, todavia deve-se destacar que os corpos com o primeiro traço acabaram se rompendo de forma frágil ao passo que os corpos moldados com considerável quantidade de fibra de PVA tiveram apenas pequenas fissuras, como se pode notar nas 
Figuras 4.31, 4.32 e 4.33. Em se comparando V5L30F2 e V5L30F4, notourse que ambas apresentaram peque nas fissuras, entretanto as fissuras da segunda mistura foram praticamente insignificantes além de sua resistência ser superior, o que prova que a introdução de fibra provoca maior ligação entre os elementos que compõem a matriz.

Utilizando-se vermiculita, a tendência é de se diminuir as resistências à compressão e à tração e também o módulo de elasticidade, entretanto, com a adição de látex e, sobretudo, de uma quantidade considerável de fibra a esta mistura, sua resistência praticamente se equivale à resistência do corpo sem vermiculita com a vantagem de evitar grandes fissuras, lascamento ou rompimento, tornando-se ideal para ser utilizado como elemento de apoio. Também se percebe que as misturas adquirem uma consistência mais mole e permitem um maior afundamento do corpo-de-prova, com menores fissuras, ao se utilizar maiores quantidades de vermiculita.

De uma forma geral, percebe-se que a utilização da fibra de vidro promove grandes acréscimos na resistência à tração, acréscimos consideravelmente maiores que aqueles que a mesma fibra promove quando se trata de resistência à compressão axial. Por exemplo, ao se comparar misturas com as mesmas quantidades de vermiculita (25\%) e látex (30\%) e substituindo a fibra de PVA por fibra de vidro (2\% em massa), obtém-se um acréscimo de quase $23 \%$ na resistência à tração.

Avaliando-se o caso anterior com relação à resistência à compressão (axial) essa diferença cai para algo em torno de $12 \%$. Independente da quantidade de vermiculita, fica claro que o acréscimo de resistência proporcionado pela substituição da fibra de PVA pela de vidro é mais relevante quando se trata de resistência de corpos-de-prova cilíndricos à tração.

Com relação à elasticidade, percebeutse que esta também se eleva ao se substituir a fibra de PVA pela de vidro, todavia o acréscimo no seu valor é, em geral, inferior a $5 \%$, portanto bastante pequeno em relação ao acréscimo de resistência à tração que a fibra de vidro proporciona.

Para melhor compreensão acerca dos resultados anteriormente mostrados, estabelecem-se, na sequiência, algumas relações entre as resistências médias à compressão, à tração por compressão diametral e o módulo de elasticidade. 
Na Tabela 4.4 podem-se observar os valores das resistências à compressão e à tração por compressão diametral dos 20 traços ensaiados. Nesta tabela, também se pode observar o valor da razão entre a resistência à compressão $\left(f_{c}\right)$ e a resistência à tração $\left(f_{t}\right)$ para cada um dos traços estudados. Todavia, para que possa haver uma melhor avaliação das razões entre as referidas resistências para cada traço, optou-se por construir um gráfico no qual se apresentam os valores dessas correlações, conforme pode se observar na Figura 4.34.

Tabela 4.4 - Relação entre resistência à compressão e à tração $\left(\mathrm{f}_{\mathrm{c}} / \mathrm{f}_{\mathrm{t}}\right)$

\begin{tabular}{||c|c|c|c||}
\hline Traço & $\mathbf{f}_{\mathbf{c}}(\mathbf{M P a})$ & $\mathbf{f}_{\mathbf{t}}(\mathbf{M P a})$ & $\mathbf{f}_{\mathbf{c}} / \mathbf{f}_{\mathbf{t}}$ \\
\hline V50L30VD2 & 12,55 & 2,08 & $\mathbf{6 , 0 3}$ \\
\hline V25L30F3 & 21,64 & 2,99 & $\mathbf{7 , 2 4}$ \\
\hline V25L30F2 & 20,92 & 2,79 & $\mathbf{7 , 5 0}$ \\
\hline V25L30VD2 & 22,93 & 3,52 & $\mathbf{6 , 5 1}$ \\
\hline V10L30F3 & 31,18 & 3,70 & $\mathbf{8 , 4 3}$ \\
\hline V5L40F3 & 22,48 & 3,64 & $\mathbf{6 , 1 8}$ \\
\hline V5L30F0 & 31,43 & 3,50 & $\mathbf{8 , 9 8}$ \\
\hline V5L30F1 & 31,59 & 4,00 & $\mathbf{7 , 9 0}$ \\
\hline V5L30F2 & 33,44 & 4,02 & $\mathbf{8 , 3 2}$ \\
\hline V5L30F3 & 34,46 & 4,10 & $\mathbf{8 , 4 0}$ \\
\hline V5L30F4 & 35,13 & 4,32 & $\mathbf{8 , 1 3}$ \\
\hline V5L20F2 & 36,94 & 4,36 & $\mathbf{8 , 4 7}$ \\
\hline V5L0F3 & 41,82 & 2,92 & $\mathbf{1 4 , 3 2}$ \\
\hline V0L40F2 & 28,12 & 3,69 & $\mathbf{7 , 6 2}$ \\
\hline V0L0F0 & 47,04 & 4,43 & $\mathbf{1 0 , 6 2}$ \\
\hline V0L30F2 & 45,03 & 4,08 & $\mathbf{1 1 , 0 4}$ \\
\hline V0L30F3 & 37,90 & 4,39 & $\mathbf{8 , 6 3}$ \\
\hline V0L30F4 & 35,38 & 4,68 & $\mathbf{7 , 5 6}$ \\
\hline V5L30VD2 & 34,36 & 4,71 & $\mathbf{7 , 3 0}$ \\
\hline V5L30VD3 & 35,19 & 4,79 & $\mathbf{7 , 3 5}$ \\
\hline \hline
\end{tabular}

Na Tabela 4.4 pode-se observar um valor de relação $\left(f_{c} / f_{t}\right)$ bastante divergente dos demais. Trata-se do traço V5L0F3, cujo valor dessa relação é 14,32 e acredita-se que deva ter ocorrido algum problema com os valores dos copos-de-prova do referido traço, sobretudo em razão de sua resistência à tração por compressão diametral ser bastante inferior à dos demais traços ensaiados. 


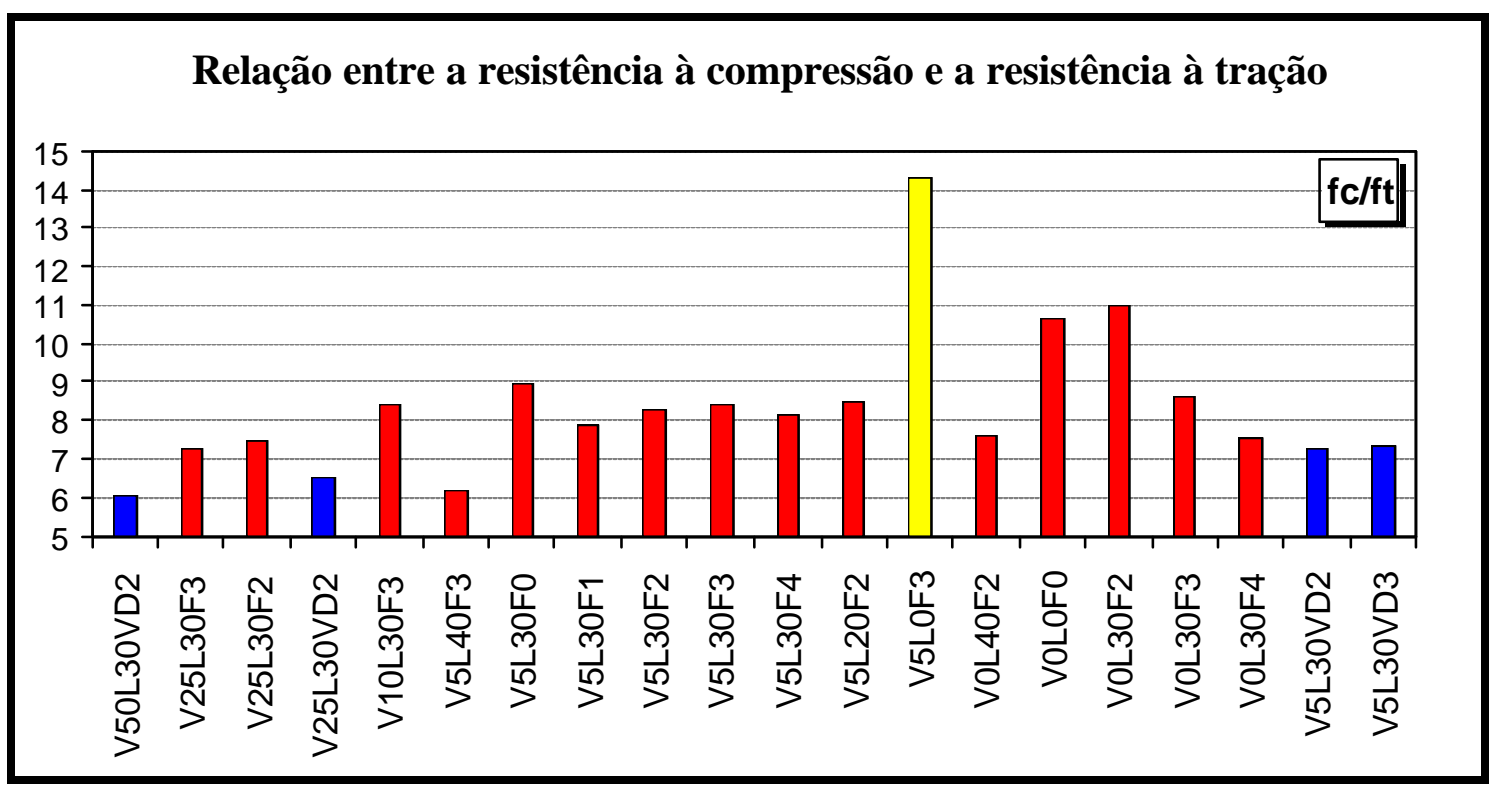

Figura 4.34 - Gráfico representativo de $\mathrm{f}_{\mathrm{c}} / \mathrm{f}_{\mathrm{t}}$ para todos os traços

Ao se observar a Figura 4.34 nota-se que a razão entre as resistências é maior quando se utiliza fibra de PVA em se comparada à razão atribuída pela introdução de fibra de vidro ao compósito, sendo que essa diferença é ainda maior quando se trata de compósitos com pequena quantidade de vermiculita, no caso $5 \%$ desse material.

Observa-se também que quanto menor a quantidade de vermiculita empregada no compósito maior é a relação entre $€$ e $\mathrm{f}_{\mathrm{t}}$, sobretudo nos casos em que não se utiliza o material.

Também se percebe que quanto maior a quantidade de látex presente no compósito menor será a relação entre as resistências à compressão e à tração por compressão diametral, principalmente quando se utiliza no produto na taxa de $40 \% \mathrm{em}$ massa.

Calculou-se também a média das razões entre as resistências à compressão e à tração para todos os traços moldados com $0 \%, 5 \%, 10 \%, 25 \%$ e $50 \%$ de vermiculita e obteve-se uma razão média para cada quantidade, conforme se observa na Tabela 4.5.

Tabela 4.5 - Relação $\mathrm{f}_{\mathrm{c}} / \mathrm{f}_{\mathrm{t}}$ variando quantidade de vermiculita

\begin{tabular}{|c|c|c|c|c|c||}
\hline Relação & $\mathbf{0 \%}$ & $\mathbf{5 \%}$ & $\mathbf{1 0 \%}$ & $\mathbf{2 5 \%}$ & $\mathbf{5 0 \%}$ \\
\hline $\mathbf{F}_{\mathbf{c}} / \mathbf{f}_{\mathbf{t}}$ & 9,09 & 8,61 & 8,43 & 7,08 & 6,03 \\
\hline
\end{tabular}


Nota-se que o valor médio da relação $€ / f_{t}$ diminui à medida que se acrescenta vermiculita aos traços. Observa-se que, em geral, o valor da relação $\mathrm{f}_{\mathrm{c}} / \mathrm{f}_{\mathrm{t}}$ é da ordem de $\mathbf{6}$ a 9.

$\mathrm{Na}$ seqüência, destaca-se a correlação entre o módulo de elasticidade (E) e resistência à compressão $\left(\mathrm{f}_{\mathrm{c}}\right)$ dos corpos-de-prova dos 20 traços ensaiados.

Na Tabela 4.6 pode-se observar os valores da resistência à compressão e das elasticidades tangente e secante, bem como das relações $\left[E / f_{c}\right]$ e $\left[E /\left(f_{c}\right)^{1 / 2}\right]$ tanto para elasticidade tangente como para elasticidade secante para os corpos-de-prova de cada um dos 20 traços ensaiados. Todavia, para que possa haver uma melhor avaliação das razões entre as referidas elasticidades e resistências para cada traço, optou-se por construir um gráfico no qual se apresentam os valores dessas correlações $\left[\mathrm{E} /\left(\mathrm{f}_{\mathrm{c}}\right)^{1 / 2}\right]$, conforme se pode observar na Figura 4.35 e, a seguir, promove-se uma comparação dos valores obtidos nessas correlações com o valor da me sma correlação para concretos com resistências entre 10 e $50 \mathrm{MPa}$.

\section{Correlações entre o módulo de elasticidade e a resistência à compressão: $E /\left(\mathbf{f}_{c}\right)^{1 / 2}$}

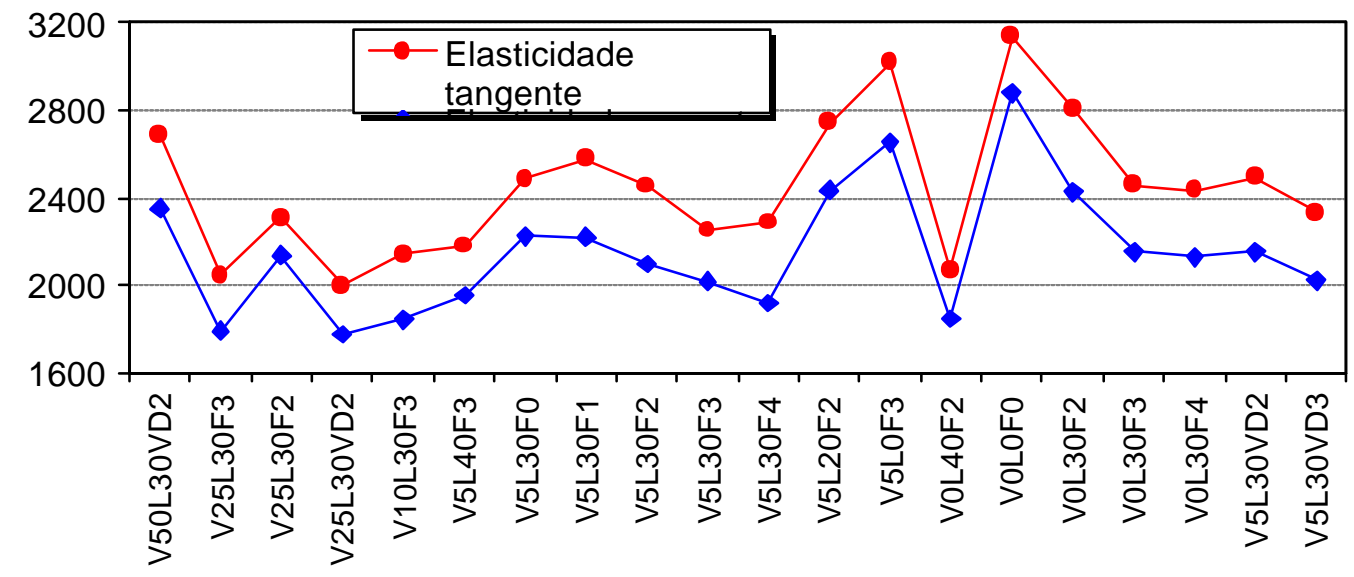

Figura 4.35 - Correlações entre Módulo de Elasticidade e Resistência à Compressão

Ao se observar a Tabela 4.6 e a Figura 4.35 nota-se que a correlação $\left[E /\left(f_{c}\right)^{1 / 2}\right]$, entre elasticidade e resistência à compressão, apresenta um valor maior quando se utiliza fibra de PVA em se comparada ao valor atribuído pela introdução de fibra de vidro ao compósito quando se utilizam grandes quantidades de fibra (25\% ou $50 \%$ do 
material). Entretanto, quando se utilizam pequenas quantidades de vermiculita o valor da correlação é praticamente idêntico.

Tabela 4.6 - Correlação entre o módulo de elasticidade e a resistência à compressão

\begin{tabular}{|c|c|c|c|c|c|c|c|}
\hline \multirow{2}{*}{ Traço } & \multirow{2}{*}{$\mathbf{f}_{\mathbf{c}}$} & \multicolumn{3}{|c|}{ Tangente } & \multicolumn{3}{|c|}{ Secante } \\
\hline & & $\mathbf{E}_{\mathrm{ct}}$ & $\mathbf{E}_{\mathrm{t}} / \mathbf{f}_{\mathbf{c}}$ & $E_{t} /\left(f_{c}\right)^{1 / 2}$ & $\mathbf{E}_{\mathrm{cs}}$ & $\mathbf{E}_{\mathrm{s}} / \mathbf{f}_{\mathbf{c}}$ & $E_{s} /\left(f_{c}\right)^{1 / 2}$ \\
\hline V50L30VD2 & 12,55 & 9519 & 758,49 & 2687,01 & 8331 & 663,82 & 2351,66 \\
\hline V25L30F3 & 21,64 & 9517 & 439,79 & 2045,84 & 8328 & 384,84 & 1790,24 \\
\hline V25L30F2 & 20,92 & 10556 & 504,59 & 2307,91 & 9776 & 467,30 & 2137,37 \\
\hline V25L30VD2 & 22,93 & 9566 & 417,18 & 1997,69 & 8490 & 370,26 & 1772,99 \\
\hline V10L30F3 & 31,18 & 11944 & 383,07 & 2139,00 & 10296 & 330,21 & 1843,87 \\
\hline V5L40F3 & 22,48 & 10347 & 460,28 & 2182,31 & 9264 & 412,10 & 1953,89 \\
\hline V5L30F0 & 31,43 & 13943 & 443,62 & 2487,05 & 12480 & 397,07 & 2226,09 \\
\hline V5L30F1 & 31,59 & 14483 & 458,47 & 2576,82 & 12490 & 395,38 & 2222,22 \\
\hline V5L30F2 & 33,44 & 14200 & 424,64 & 2455,59 & 12133 & 362,83 & 2098,14 \\
\hline V5L30F3 & 34,46 & 13224 & 383,75 & 2252,71 & 11829 & 343,27 & 2015,07 \\
\hline V5L30F4 & 35,13 & 13550 & 385,71 & 2286,13 & 11375 & 323,80 & 1919,17 \\
\hline V5L20F2 & 36,94 & 16693 & 451,89 & 2746,54 & 14799 & 400,62 & 2434,92 \\
\hline V5L0F3 & 41,82 & 19513 & 466,59 & 3017,39 & 17162 & 410,38 & 2653,85 \\
\hline V0L40F2 & 28,12 & 10987 & 390,72 & 2071,91 & 9799 & 348,47 & 1847,88 \\
\hline VOLOFO & 47,04 & 21513 & 457,33 & 3136,66 & 19764 & 420,15 & 2881,65 \\
\hline V0L30F2 & 45,03 & 18844 & 418,48 & 2808,16 & 16295 & 361,87 & 2428,31 \\
\hline V0L30F3 & 37,90 & 15141 & 399,50 & 2459,43 & 13271 & 350,16 & 2155,68 \\
\hline V0L30F4 & 35,38 & 14471 & 409,02 & 2432,87 & 12655 & 357,69 & 2127,57 \\
\hline V5L30VD2 & 34,36 & 14628 & 425,73 & 2495,50 & 12614 & 367,11 & 2151,92 \\
\hline V5L30VD3 & 35,19 & 13825 & 392,87 & 2330,53 & 12002 & 341,06 & 2023,22 \\
\hline
\end{tabular}

Com relação às fibras, nota-se que o aumento na quantidade do produto acarreta diminuição no valor das correlações $\left[\mathrm{E} / \mathrm{f}_{\mathrm{c}}\right]$ e $\left[\mathrm{E} /\left(\mathrm{f}_{\mathrm{c}}\right)^{1 / 2}\right]$, tanto para a fibra de vidro como para a fibra de PVA.

Observa-se também que quanto menor a quantidade de látex empregada no compósito maior é o valor da referida correlação entre elasticidade e resistência à compressão, sobretudo nos casos em que não se utiliza o material. Nota-se, portanto, que ao se utilizar látex na taxa de $40 \%$ em massa, obtém-se o menor valor para a correlação, aproximadamente 2070 quando se trata de elasticidade tangente e 1850 quando se trata de elasticidade secante. 
Calculoutse também a média das correlações $\left[\mathrm{E} /\left(\mathrm{f}_{\mathrm{c}}\right)^{1 / 2}\right]$ para os traços com $0 \%$, $5 \%, 10 \%, 25 \%$ e $50 \%$ de vermiculita tanto para o caso de elasticidade tangente como para o caso de se utilizar o valor da elasticidade secante e seus respectivos valores podem ser observados na Tabela 4.7.

Tabela 4.7 - Relação $\left[E /\left(f_{c}\right)^{1 / 2}\right]$ variando quantidade de vermiculita

\begin{tabular}{||c|c|c|c|c|c||}
\hline $\mathbf{E} /\left(\mathbf{f}_{\mathbf{c}}\right)^{\mathbf{1 / 2}}$ & $\mathbf{0 \%}$ & $\mathbf{5 \%}$ & $\mathbf{1 0 \%}$ & $\mathbf{2 5 \%}$ & $\mathbf{5 0 \%}$ \\
\hline tangente & 2709 & 2196 & 2139 & 2177 & 2687 \\
\hline secante & 2398 & 2046 & 1844 & 1900 & 2352 \\
\hline
\end{tabular}

Na Tabela 4.7, nota-se que, em geral, a correlação $\left[\mathrm{E} /\left(\mathrm{f}_{\mathrm{c}}\right)^{1 / 2}\right]$ entre o módulo de elasticidade tangente e a resistência à compressão tem seu valor no intervalo entre $\mathbf{2 1 0 0}$ e 2700 para a maior parte dos traços moldados com vermiculita, látex e fibras. Também se observa que a relação atinge maiores valores nos casos em que não se utiliza vermiculita e naqueles casos em que se utiliza o material em grande quantidade (50\%).

Para se ter uma idéia da ordem de grandeza dos resultados apresentados para os traços do compósito far-se-á uma comparação destes com o valor da mesma correlação no caso de se utilizar concreto.

Pela Revisão da NB-1 (1999), para concretos com resistências entre 10 e 50MPa (no caso dos traços do referido compósito ensaiado, os valores das resistências estão entre 12,55 e 47,04MPa), tem-se:

$$
E_{c}=0,85 \cdot 5600 \cdot \sqrt{f_{c k}} \Rightarrow \frac{E_{c}}{\sqrt{f_{c k}}}=4760
$$

Os valores da correlação para o concreto e para traços com $0 \%, 5 \%, 10 \%, 25 \%$ e $50 \%$ de vermiculita, utilizando os valores de elasticidade tangente, são mostrados no gráfico da Figura 4.36 


\section{Correlação entre o Módulo de Elasticidade e a Resistência à} Compressão: $\mathbf{E} /\left(\mathbf{f}_{\mathbf{c}}\right)^{1 / 2}$

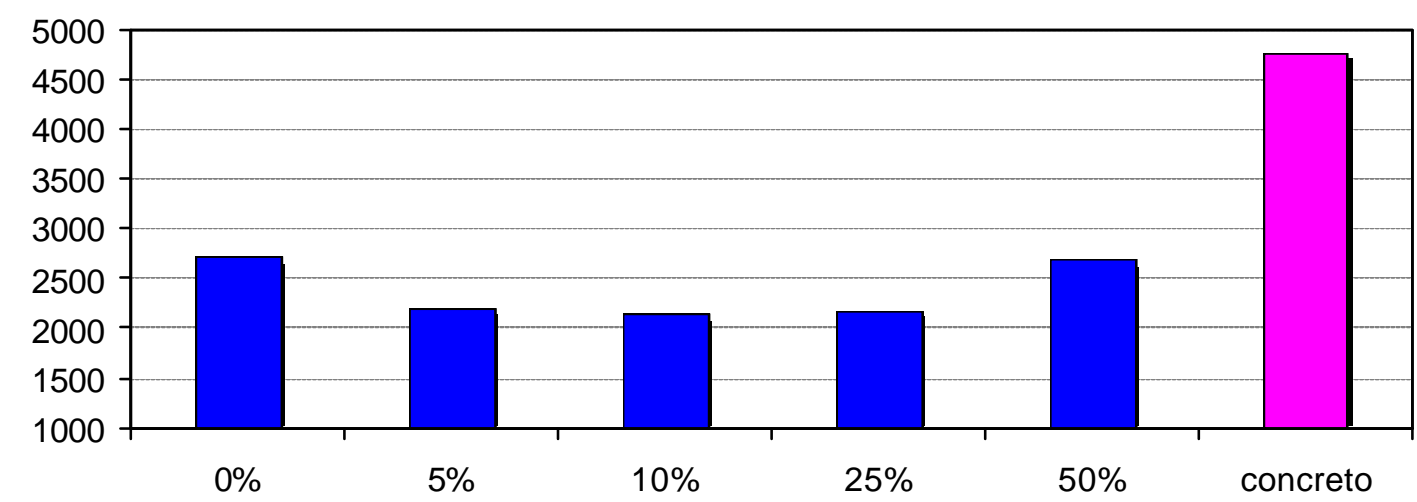

Figura 4.36 - Correlações entre Módulo de Elasticidade e Resistência à Compressão para o compósito e o concreto com resistência entre 10 e 50MPa

Ao se comparar os valores da correlação estudada, nota-se que o valor da correlação para os traços do compósito utilizando elasticidade tangente vale de $45 \%$ a $50 \%$ do valor obtido para concretos com resistência entre 10 e 50MPa. Dessa forma, conclui-se que, em geral, a razão entre as correlações concreto/compósito varia de $\mathbf{2}$ a 2,5 .

Como se espera que as almofadas possuam baixo módulo de elasticidade ao mesmo tempo que tenham resistência tão alta quanto possível, conclui-se que os melhores valores para a relação estudada são os das misturas que apresentarem o menor valor possível para a relação $\left[\mathrm{E} /\left(\mathrm{f}_{\mathrm{c}}\right)^{1 / 2}\right]$. Sendo assim, admite-se que o traço procurado deve possuir quantidade de vermiculita variando entre $5 \%$ e $25 \%$. Acredita-se, ainda, que um ponto ótimo deva ser algo mais próximo de $10 \%$ a $15 \%$ de vermiculita. 


\subsection{Ensaios de placas}

Neste capítulo, tratar-se-á especificamente dos resultados experimentais dos ensaios realizados nas almofadas, tais como: rigidez mediante ensaio de compressão $e$ afundamento. Para tal, estabelecer-se-á uma análise crítica dos resultados a partir de comparação dos mesmos, a fim de distinguir as peculiaridades das almofadas de cada traço.

\subsubsection{Ensaio de carga uniforme}

O ensaio de compressão foi realizado em placas do compósito com o intuito de se obter a rigidez da placa, que corresponde à capacidade do material de se deformar (sem se romper) e que pode ser representada pela equação 4.3, conforme explicado no capítulo 3.5.2.

$$
\mathrm{R}=\frac{\sigma}{\frac{\Delta \mathrm{h}}{\mathrm{h}}}
$$

Onde:

$$
\begin{aligned}
& \text { R: rigidez da placa } \\
& \sigma: \text { tensão aplicada }
\end{aligned}
$$

$\Delta$ h: variação da espessura da placa

h: espessura da placa

A forma como o ensaio foi realizado bem como as equações utilizadas para o cálculo das rigidezes são apresentadas no capítulo 3.5.2. Naquele capítulo também são mostrados os resultados de um traço específico (V5L30F3) para almofadas com 5mm de espessura e área da base $15 \mathrm{~cm}$ x $15 \mathrm{~cm}$, obtendo-se uma rigidez média $240 \mathrm{MPa}$ para aquele caso, sendo o procedimento repetido para as outras espessuras (10 e 20mm) daquele traço específico. Aquele procedimento de cálculo é também utilizado para os demais traços e, neste capítulo, far-se-á uma comparação dos resultados obtidos para as almofadas dos 13 traços ensaiados, bem como das madeiras (pinus e eucalipto) e cloropreno (neoprene). 
Nas Tabelas 4.8 e 4.9, pode-se verificar os resultados das rigidezes para cada espessura e traços ensaiados para as placas de $15 \mathrm{~cm} \times 15 \mathrm{~cm}$ e para as de $10 \mathrm{~cm} \times 10 \mathrm{~cm}$, respectivamente.

Tabela 4.8 - Ensaios de rigidez das placas de $15 \mathrm{~cm}$ x $15 \mathrm{~cm}$

\begin{tabular}{|c|c|c|c|c|c|c|}
\hline \multirow[t]{2}{*}{ Traço } & \multicolumn{3}{|c|}{ Rigidez de placa (MPa) } & \multicolumn{3}{|c|}{$\begin{array}{c}\text { Deslocamento }(\mathrm{mm}) \text { para } \mathrm{F} \\
=500 \mathrm{kN}\end{array}$} \\
\hline & $\mathrm{e}=5 \mathrm{~mm}$ & $\mathrm{e}=10 \mathrm{~mm}$ & e $=20 \mathrm{~mm}$ & $\mathrm{e}=5 \mathrm{~mm}$ & $\mathrm{e}=10 \mathrm{~mm}$ & $\mathrm{e}=20 \mathrm{~mm}$ \\
\hline VOLOF0 & 236 & 469 & 740 & 1,15 & 1,29 & 1,42 \\
\hline V0L30F3 & 253 & 460 & 752 & 1,29 & 1,38 & 1,68 \\
\hline V5L30F2 & 224 & 442 & 724 & 1,31 & 1,42 & 1,77 \\
\hline V5L30F3 & 240 & 447 & 728 & 1,35 & 1,45 & 1,80 \\
\hline V5L30F4 & 256 & 461 & 750 & 1,44 & 1,55 & 1,90 \\
\hline V10L30F3 & 202 & 337 & 531 & 1,46 & 1,60 & 2,01 \\
\hline V25L30F2 & 165 & 226 & 402 & 1,61 & 1,92 & 3,00 \\
\hline V5L30VD2 & 228 & 440 & 731 & 1,35 & 1,43 & 1,78 \\
\hline V5L30VD3 & 244 & 453 & 734 & 1,36 & 1,50 & 1,81 \\
\hline V25L30VD2 & 169 & 224 & 410 & 1,63 & 1,93 & 2,98 \\
\hline V50L30VD2 & 88 & 125 & 173 & 1,99 & 2,58 & 4,37 \\
\hline V5L30PP2 & 219 & 431 & 718 & 1,29 & 1,40 & 1,73 \\
\hline
\end{tabular}

\begin{tabular}{||c|c|c|c||}
\hline Pinus taeda & - & 68 & 126 \\
\hline Eucalipto citriodora & - & 144 & 283 \\
\hline Cloropreno (neoprene) & - & 73 & 38 \\
\hline
\end{tabular}

Tabela 4.9 - Ensaios de rigidez das placas de $10 \mathrm{~cm} \times 10 \mathrm{~cm}$

\begin{tabular}{||c|c|c|c|c|c|c||}
\hline \multirow{2}{*}{ Traço } & \multicolumn{3}{|c|}{ Rigidez de placa (MPa) } & \multicolumn{3}{c|}{$\begin{array}{c}\text { Deslocamento (mm) para F } \\
\mathbf{5} \mathbf{5 0 0 k N}\end{array}$} \\
\cline { 2 - 8 } & e = 5mm & e = 10mm & e = 20mm & e = 5mm & e = 10 mm & e = 20mm \\
\hline V0L0F0 & - & 881 & 1519 & - & 1,36 & 1,46 \\
\hline V5L30F3 & - & 558 & 914 & - & 1,62 & 1,82 \\
\hline V25L30F2 & - & 315 & 352 & - & 2,59 & 5,21 \\
\hline V25L30VD2 & - & 326 & 377 & - & 2,68 & 5,19 \\
\hline V50L30VD2 & - & 228 & 260 & - & 3,45 & 6,53 \\
\hline
\end{tabular}

\begin{tabular}{||c|c|c|c||}
\hline Pinus taeda & - & 89 & 159 \\
\hline Eucalipto citriodora & - & 189 & 328 \\
\hline Cloropreno (neoprene) & - & 102 & 47 \\
\hline
\end{tabular}


Em geral, nota-se que o acréscimo de fibras promove um aumento no valor da rigidez das almofadas do compósito e o acréscimo de vermiculita, por sua vez, acarreta diminuição no valor dessa rigidez. Verifica-se, também, que quanto maior a espessura maior será a rigidez da almofada e acredita-se que isso ocorra devido às imperfeições presentes nas bordas inferior e superior da placa, já que essas imperfeições correspondem a uma maior porção percentual no caso de se utilizar almofadas de menor espessura, influenciando de forma mais acentuada nesses casos (Figura 4.40). Também se nota que o deslocamento é maior quando se acrescenta maiores quantidades de vermiculita à mistura.

Nota-se que todos os traços que compunham as almofadas de $10 \mathrm{~cm} \times 10 \mathrm{~cm}$ apresentaram rigidez maior que as rigidezes das madeiras e que do neoprene. Da mesma forma, as rigidezes das almofadas do compósito foram maiores que das madeiras e que do neoprene, com exceção das placas de V50L30VD2, cujas rigidezes foram menores que as da madeira mais dura (Eucalipto Citriodora), entretanto a rigidez à compressão desse tipo de madeira é praticamente superior a 3 vezes a resistência à compressão de corpos do referido traço. Sendo assim, as almofadas desse traço deveriam ser comparadas a almofadas da outra madeira (Pinus Taeda), de resistência à compressão próxima a sua e, neste caso, as almofadas do compósito apresentaram rigidez bastante superior à desta última madeira, praticamente o dobro.

Para dar prosseguimento à análise, observar-se-ão, nesse momento, apenas os resultados referentes à Tabela 4.8 .

Para verificar a influência da vermiculita pode-se observar o $2^{\circ}, 4^{\circ}$ e $6^{\circ}$ traços, em que se utilizam respectivamente $0 \%, 5 \%$ e $10 \%$ do material, todos acrescidos de $30 \%$ de látex e 3\% de fibra de PVA. Quando se acrescenta 5\% de vermiculita ao traço em que não se utilizava o material, nota-se uma queda no valor da rigidez de aproximadamente $5 \%, 3 \%$ e $3 \%$ para as espessuras 5,10 e $20 \mathrm{~mm}$, respectivamente. Todavia, se esse mesmo acréscimo for de $10 \%$ de vermiculita, tem-se para as mesmas espessuras, decréscimo da ordem de $20 \%, 27 \%$ e $30 \%$, respectivamente. Nota-se que quanto maior $\mathrm{o}$ acréscimo de vermiculita à mistura, maior a queda do valor de rigidez e maior o deslocamento, sobretudo nos casos em que se empregam maiores espessuras nas almofadas e traços com quantidade de vermiculita acima de $10 \%$. 
Com relação à influência do látex, em apenas um traço se utilizou quantidade do produto diferente de $30 \%$ em massa. Isso ocorreu apenas no $1^{\circ}$ traço, argamassa simples ou o chamado traço de referência. Em se comparando os seus resultados com os demais traços, nota-se que os valores das rigidezes apresentados pelas almofadas deste traço são bastante próximos dos valores das rigidezes apresentados pelo $4^{\circ}$ e $10^{\circ}$ traços, nos quais se utilizam 5\% de vermiculita, $30 \%$ de látex e $3 \%$ de fibras (de PVA e vidro, respectivamente).

Para melhor avaliar a influência do acréscimo de fibras, pode-se observar o $3^{\circ}, 4^{\circ}$ e $5^{\circ}$ traços da Tabela 4.8, nas quais se utilizam respectivamente $2 \%$, $3 \%$ e $4 \%$ de fibra de PVA, todos acrescidos de 5\% de vermiculita e 30\% de látex em massa. Quando se acrescenta $1 \%$ de fibra de PVA ao traço em que se utilizava apenas $1 \%$ do material, nota-se um aumento no valor da rigidez de aproximadamente $7 \%, 1 \%$ e $0,5 \%$ para as espessuras 5, 10 e 20mm, respectivamente. Todavia, se esse mesmo acréscimo for de $2 \%$ de fibra de PVA (do traço 3 para o traço 5), tem-se para as mesmas espessuras, aumento da ordem de $14 \%, 4 \%$ e $3 \%$, respectivamente. Nota-se que quanto maior o acréscimo de fibra à mistura, maior o acréscimo do valor de rigidez e maior o deslocamento, sobretudo nos casos em que se empregam menores espessuras nas almofadas. Ocorre, no caso das fibras, o oposto do que ocorria no caso do acréscimo de vermiculita, já que no caso de se acrescentar vermiculita ocorriam decréscimos nos valores das rigidezes e os maiores decréscimos aconteciam para as maiores espessuras das almofadas.

Ao se comparar os três tipos de fibras, nota-se que os valores das rigidezes para as fibras de PVA e de vidro são mais próximos ao passo que os valores apresentados pela fibra de polipropileno são mais distintos e relativamente menores. Para verificar a proximidade dos valores das rigidezes da fibra de PVA e da fibra de vidro, basta comparar o $3^{\circ}$ e o $9^{\circ}$ traços da Tabela 4.8 , nos quais se utilizam $5 \%$ de vermiculita, $30 \%$ de látex e $2 \%$ de fibra (PVA e vidro, respectivamente)

Avaliando-se, de forma isolada, a fibra de vidro, pode-se notar novamente a influência do acréscimo de vermiculita no sentido de diminuir a rigidez da almofada. Para tal, basta observar o $9^{\circ}, 11^{\circ}$ e $12^{\circ}$ da Tabela 4.8 . Nota-se que ao se utilizar $50 \%$ de vermiculita, obtêm-se almofadas com rigidez de 3 a 4 vezes menores que no caso de se utilizar almofadas com 5\% do material. Ao se comparar os traços com $50 \%$ de 
vermiculita àqueles com $25 \%$ do material, nota-se que a rigidez das almofadas com $50 \%$ daquele material é praticamente metade da rigidez obtida para almofadas com $25 \%$ de vermiculita.

Para melhor avaliação dos resultados, na seqüência estão expostos alguns gráficos com as devidas comparações dos valores das rigidezes entre as almofadas compostas pelos traços previamente definidos. Também serão feitas comparações entre os valores obtidos para as almofadas do compósito e algumas placas de madeira e neoprene, como referência. E, ainda, será efetuada análise do efeito de forma das almofadas, mediante comparação dos valores das rigidezes das placas de área da base maior $(15 \mathrm{~cm} \mathrm{x} 15 \mathrm{~cm}) \mathrm{e}$ menor $(10 \mathrm{~cm} \times 10 \mathrm{~cm})$.

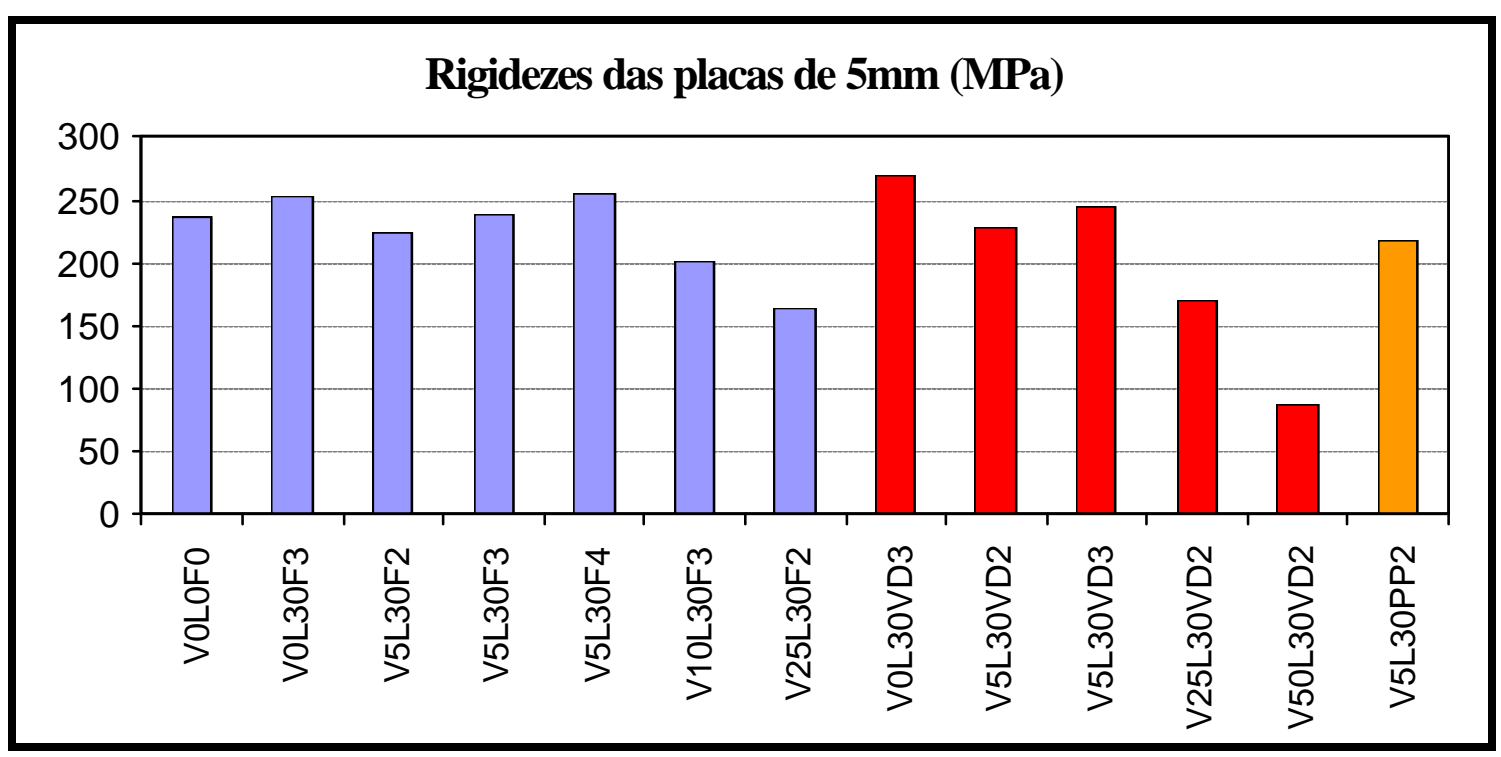

Figura 4.37 - Gráfico comparativo das rigidezes (placa de $15 \mathrm{~cm}$ x $15 \mathrm{~cm}$ x 0,5cm)

As Figuras 4.37, 4.38 e 4.39 apresentam as rigidezes das placas de $15 \mathrm{~cm}$ x $15 \mathrm{~cm}$ de área da base, com variação de espessura em 5, 10 e 20mm, respectivamente. As 7 primeiras barras de cada um dos 3 gráficos referenciados correspondem aos traços moldados com fibra de PVA, as 5 seguintes com fibra de vidro e a última barra corresponde à mistura composta por fibra de polipropileno. 


\section{Rigidezes das placas de 10mm (MPa)}

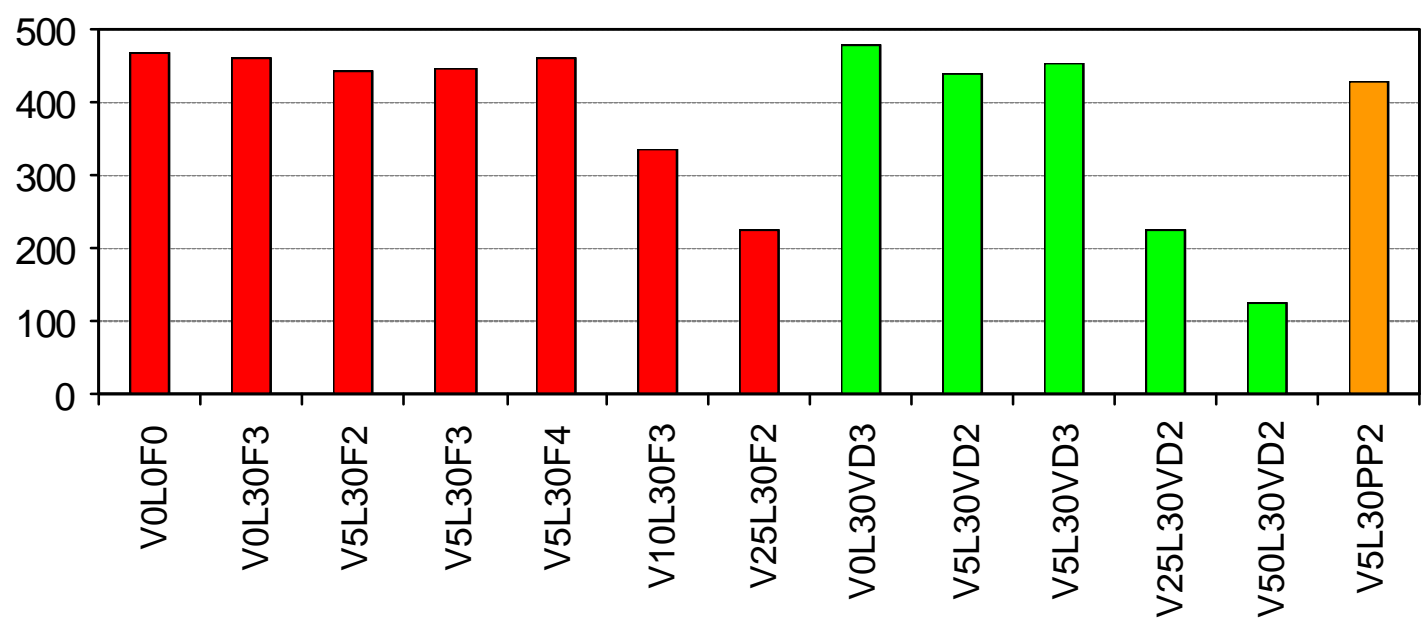

Figura 4.38 - Gráfico comparativo das rigidezes (placa de $15 \mathrm{~cm}$ x $15 \mathrm{~cm}$ x $1 \mathrm{~cm}$ )

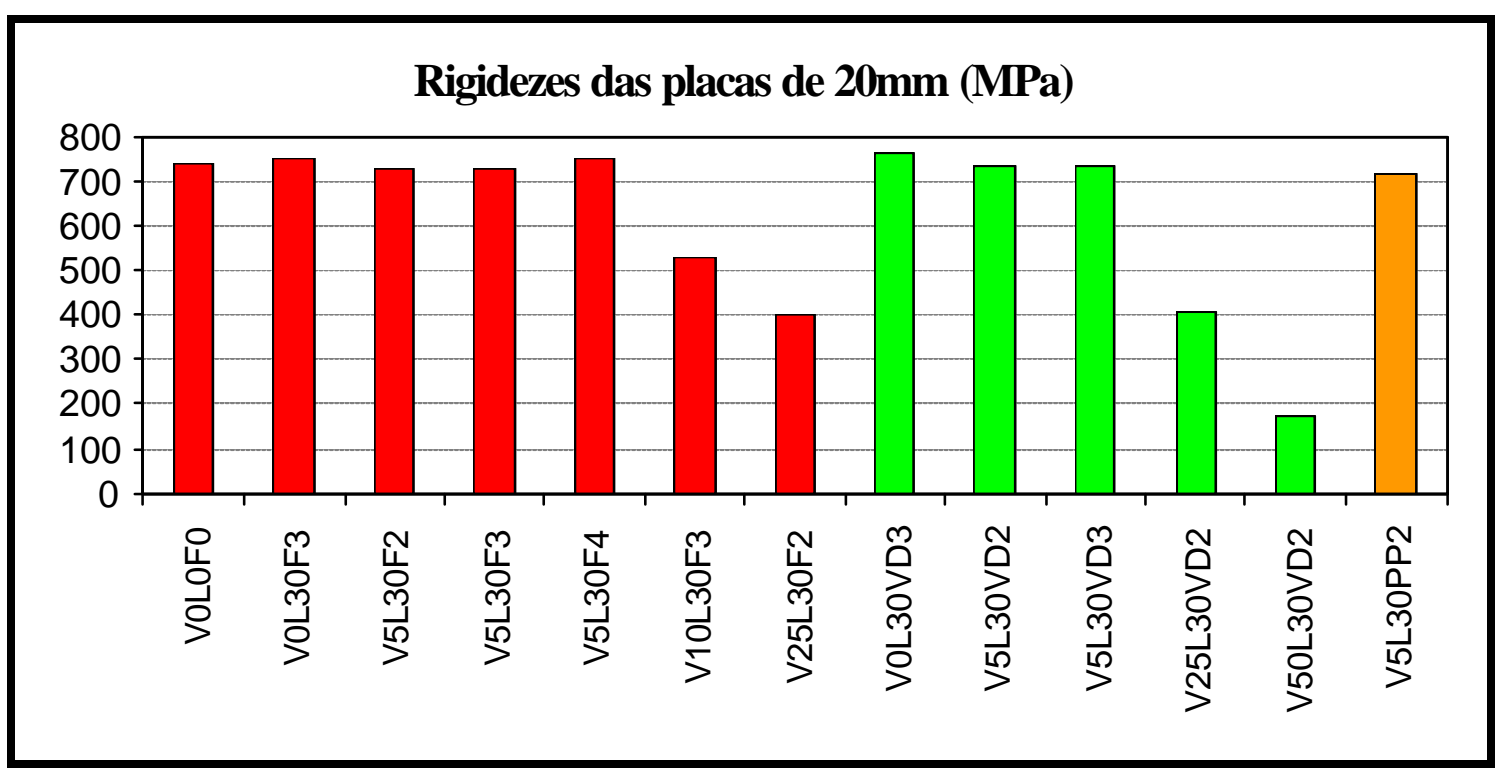

Figura 4.39 - Gráfico comparativo das rigidezes $(15 \mathrm{~cm}$ x $15 \mathrm{~cm}$ x $2 \mathrm{~cm})$

Nota-se, claramente, a influência da vermiculita no decréscimo do valor da rigidez, contrária à ação das fibras, as quais promovem, em geral, aumento da rigidez, o que pode ser notado ao se comparar $3^{\mathrm{a}}, 4^{\mathrm{a}}$ e $5^{\mathrm{a}}$ barras do gráfico da Figura 4.39, por exemplo.

Ao se realizar a avaliação por tipo de fibra ( $2 \%$ do material), nota-se que a rigidez é praticamente idêntica nos três casos.

$\mathrm{Na}$ Figura 4.40 pode-se notar claramente que quanto mais espessa for a placa maior será o valor da sua rigidez. Ao passar de $5 \mathrm{~mm}$ para $10 \mathrm{~mm}$ de espessura a rigidez 
tem seu valor praticamente dobrado; entretanto, quando se passa de $5 \mathrm{~mm}$ para $20 \mathrm{~mm}$ de espessura a rigidez tem seu valor praticamente triplicado. Acredita-se que isso ocorra em razão das imperfe ições presentes nas bordas inferior e superior das almofadas, onde se aplica a carga, e as quais são maiores percentualmente quando se utilizam almofadas mais espessas.

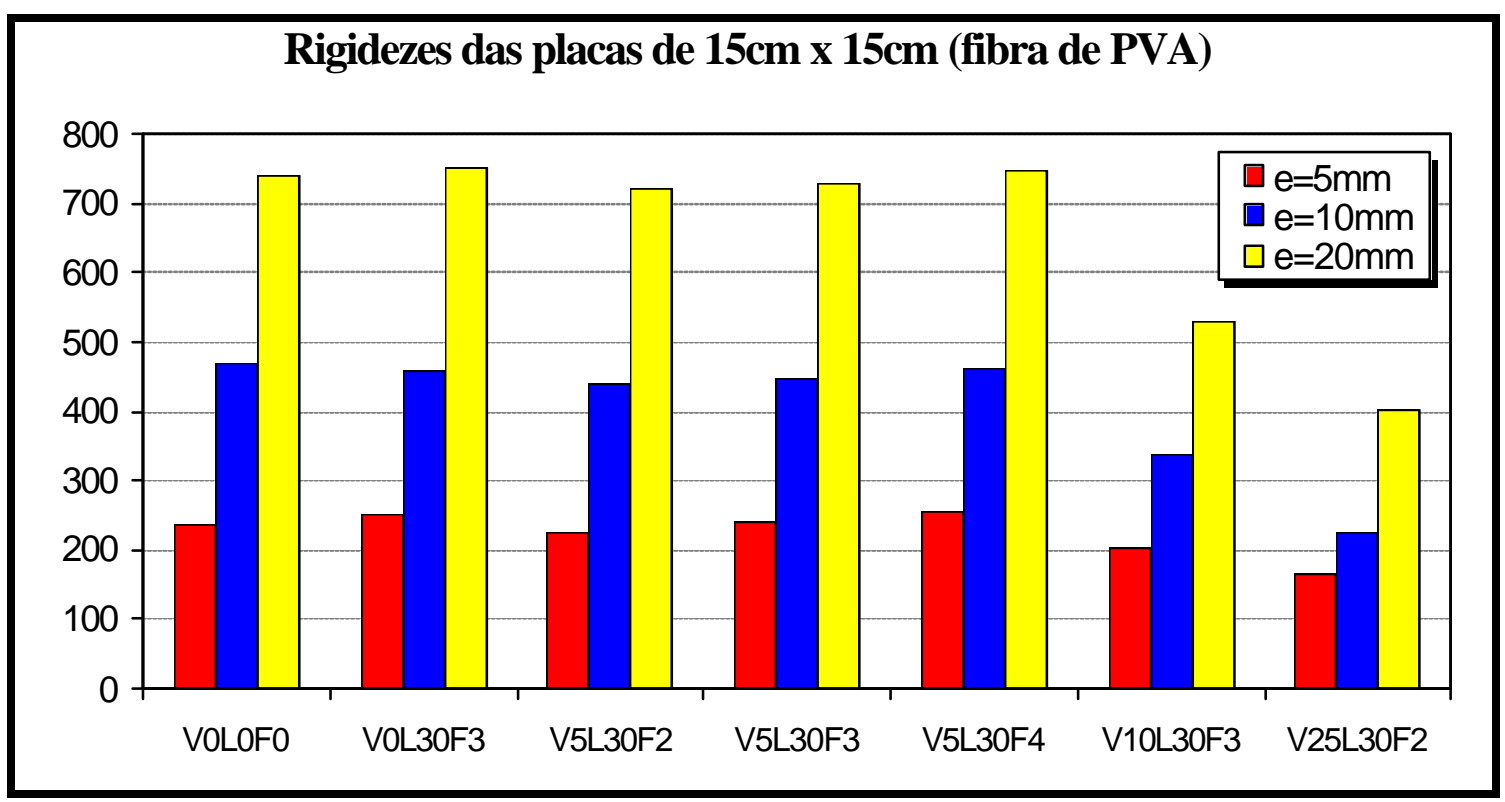

Figura 4.40 - Gráfico comparativo das rigidezes (almofadas de $15 \mathrm{~cm} \times 15 \mathrm{~cm}$ )

Ao se comparar almofadas do compósito com almofadas de madeira de mesmas dimensões, conforme as Figuras 4.41 e 4.42, nota-se claramente que almofadas do compósito que possuem resistência à compressão (simples) próxima daquela obtida para um determinado tipo de madeira, possuem rigidez bastante superior à rigidez obtida para placas daquela madeira.

$\mathrm{Na}$ Figura 4.41, por exemplo, pode-se comparar a $1^{\mathrm{a}}$ barra (V5L30F3) com as almofadas de rigidez simbolizadas na última barra daquela figura (citriodora). Esse traço e aquela madeira possuem resistências à compressão com valores praticamente idênticos, todavia a rigidez do compósito em almofadas de espessura 10mm é 3 vezes maior que a da madeira. O mesmo ocorre para a $3^{\text {a }}$ barra (V25L30VD2) e $5^{\text {a }}$ barra (pinus) da mesma figura, apesar de possuírem resistências bem próximas, a rigidez do compósito é praticamente 4 vezes maior que a da madeira. Essa diferença de rigidezes 
diminui percentualmente com o aumento da espessura da placa (Figuras 4.41 e 4.42), no entanto, a rigidez do compósito permanece bem superior à da madeira.

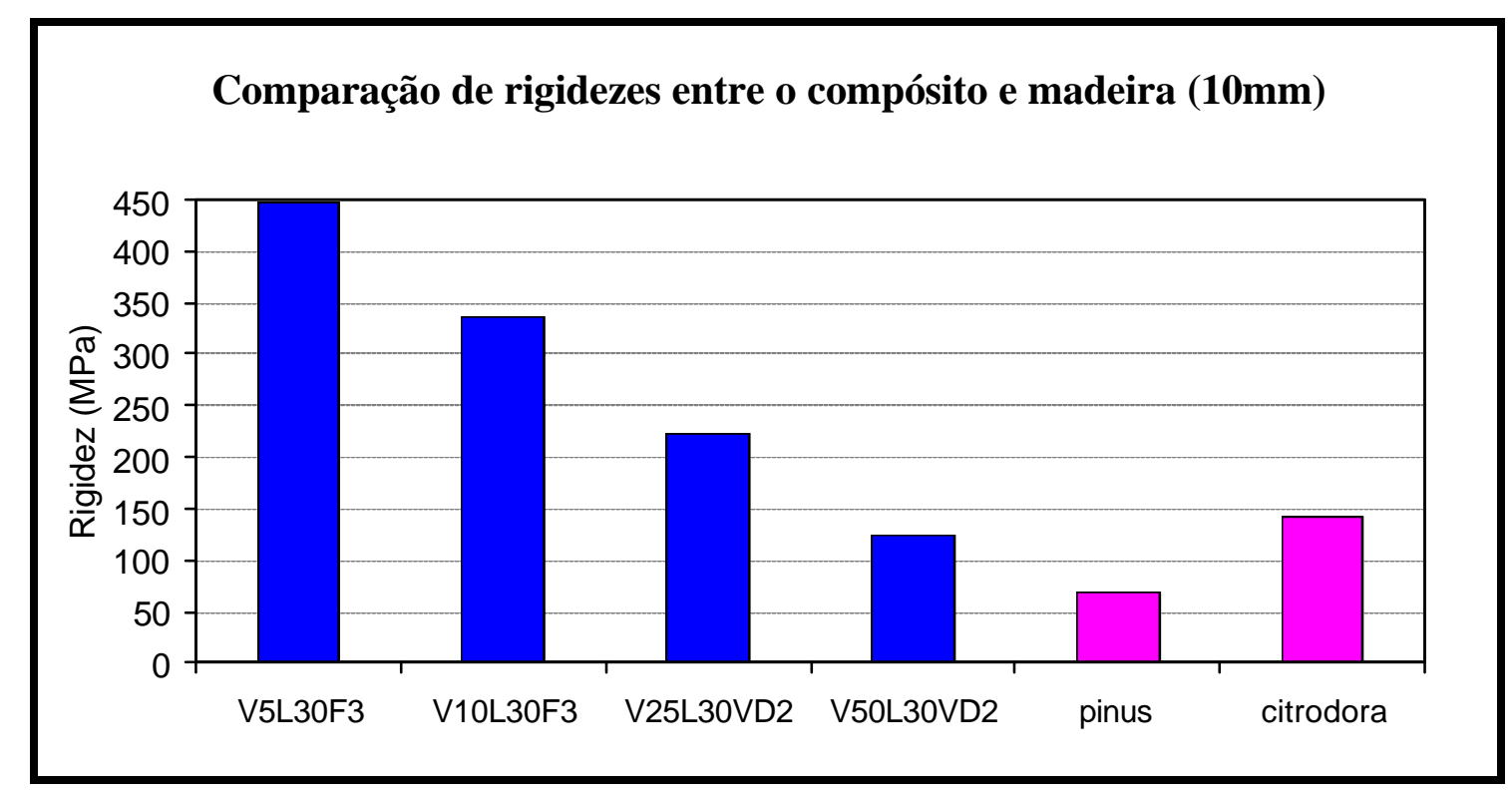

Figura 4.41 - Comparação entre placas de madeira e do compósito $(15 \mathrm{~cm} \times 15 \mathrm{~cm} \times 1 \mathrm{~cm})$

\section{Comparação de rigidezes entre o compósito e madeira $(20 \mathrm{~mm})$}

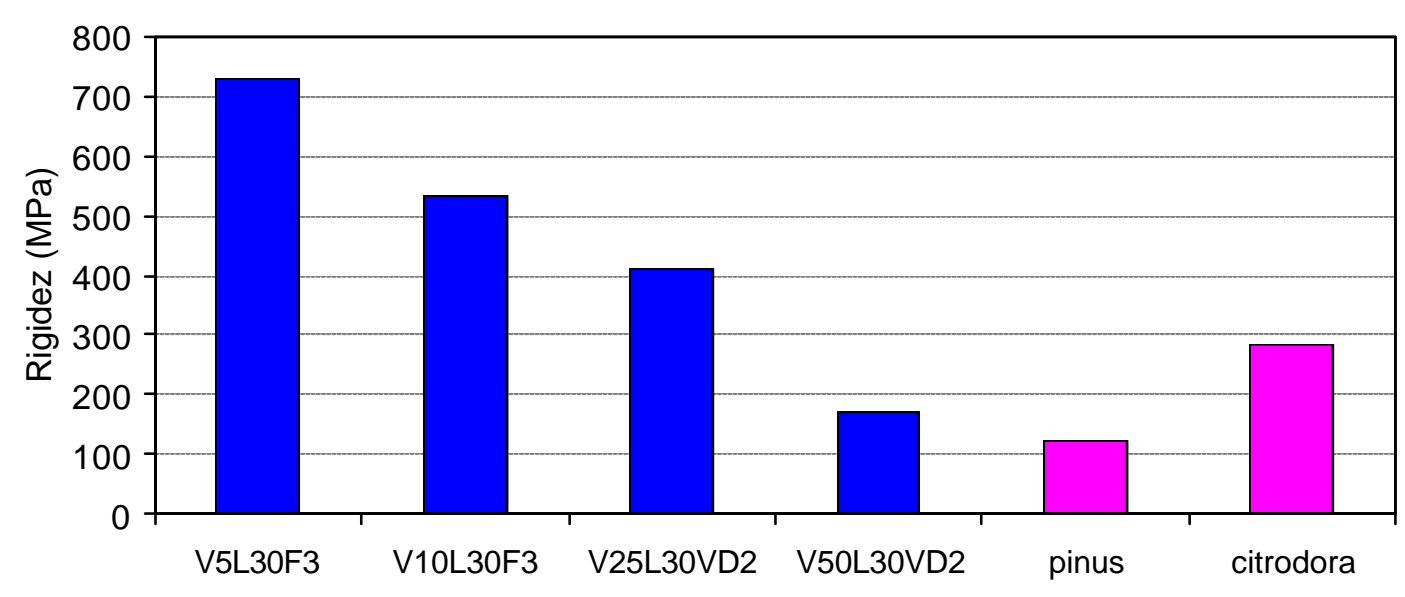

Figura 4.42 - Comparação entre placas de madeira e do compósito

$(15 \mathrm{~cm} \times 15 \mathrm{~cm} \times 2 \mathrm{~cm})$ 
Realizando a mesma comparação para as placas de menor área $(10 \mathrm{~cm} \times 10 \mathrm{~cm})$, conforme Figura 4.43, nota-se novamente que a rigidez, independente da diferença, é bem maior para almofadas do compósito. Nessa figura ainda se pode realizar uma comparação do compósito com o elastômero mais utilizado no Brasil em ligações entre elementos pré-moldados, o cloropreno (neoprene). Nota-se que mesmo a almofada mais macia e menos resistente (V50L30VD2) possui um valor de rigidez superior a 2 vezes o valor da rigidez do referido elastômero para as mesmas condições de aplicação de carga de compressão.

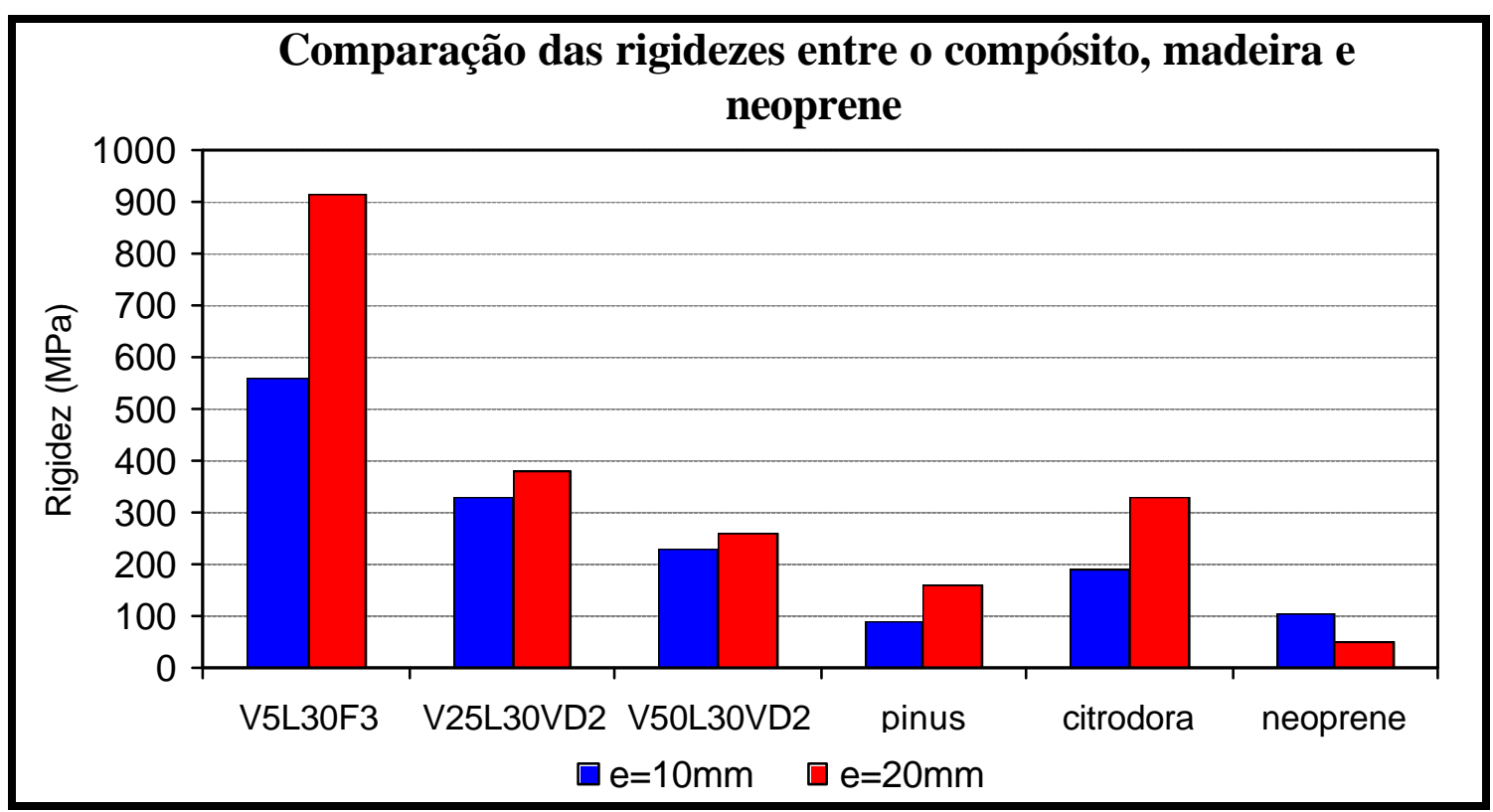

Figura 4.43 - Comparação entre placas de madeira, de neoprene e do compósito (placas de $10 \mathrm{~cm} \times 10 \mathrm{~cm})$

Na Figura 4.43 também se nota que a diferença das rigidezes entre almofadas de mesmo traço, porém com espessuras distintas, já não apresentam valores tão diferentes como no caso das almofadas de $15 \mathrm{~cm}$ x $15 \mathrm{~cm}$. Seus valores são mais próximos para o caso de se utilizar almofadas de $10 \mathrm{~cm} \times 10 \mathrm{~cm}$ e acredita-se que isso ocorra pelo fato de as imperfeições aparecerem em menor escala neste caso, em razão de se ter uma menor área de aplicação da carga.

Ao se observar as Figuras 4.44 e 4.45, pode-se avaliar o efeito de forma de placas do compósito e também das madeiras e do neoprene. Nota-se que ao se diminuir a área de $15 \mathrm{~cm} \times 15 \mathrm{~cm}$ para $10 \mathrm{~cm} \times 10 \mathrm{~cm}$ ocorre um acréscimo de rigidez que varia de $40 \%$ a 
50\% para placas de V5L30F3. Com relação à mudança no tipo de fibra, de PVA para vidro, nota-se que o acréscimo de rigidez tem, aproximadamente, essa mesma proporção. Todavia, quando se trata da influência da vermiculita, percebe-se que nas misturas com maior quantidade deste material (V25L30VD2), esse acréscimo fica entre $60 \%$ e $70 \%$.

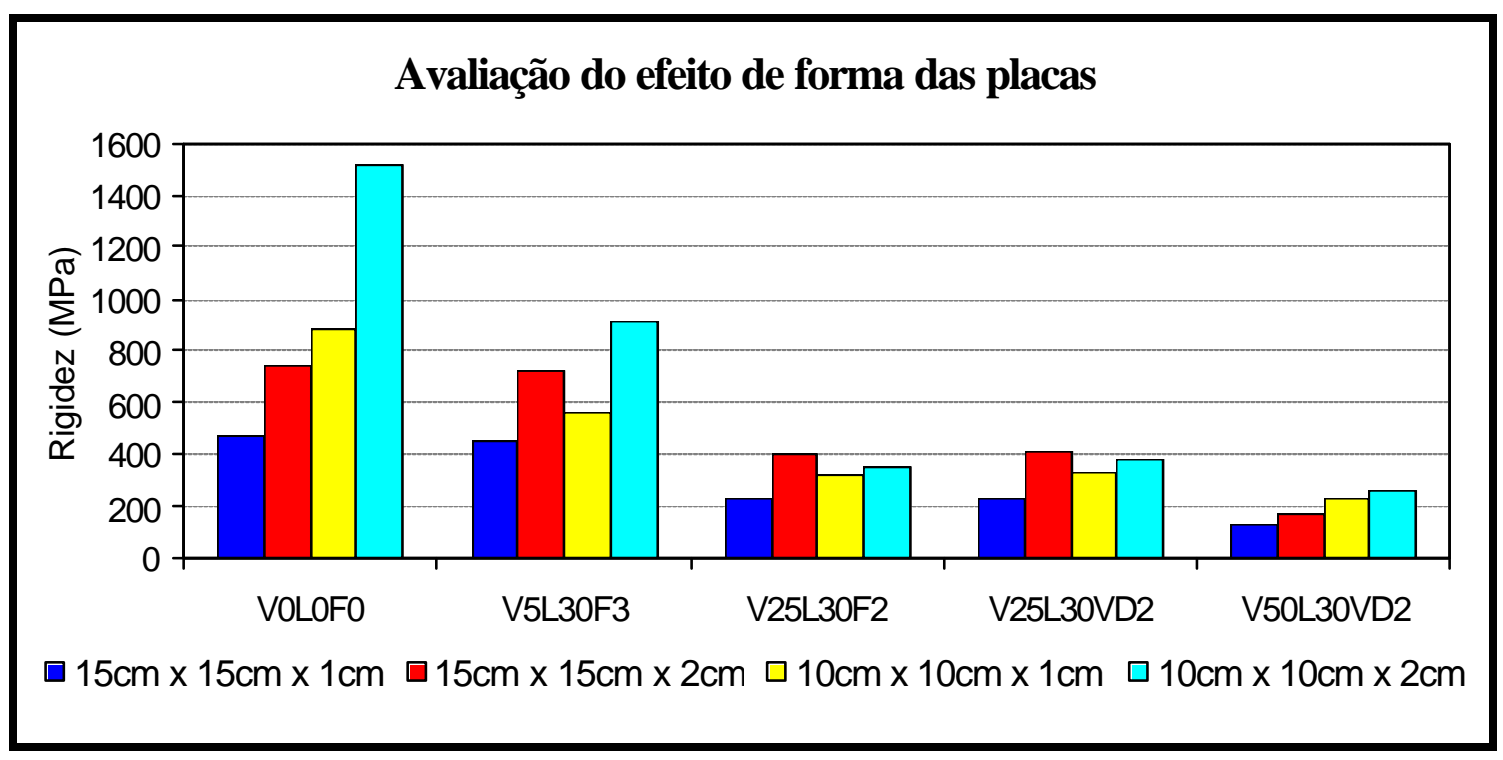

Figura 4.44 - Efeito de forma em placas do compósito

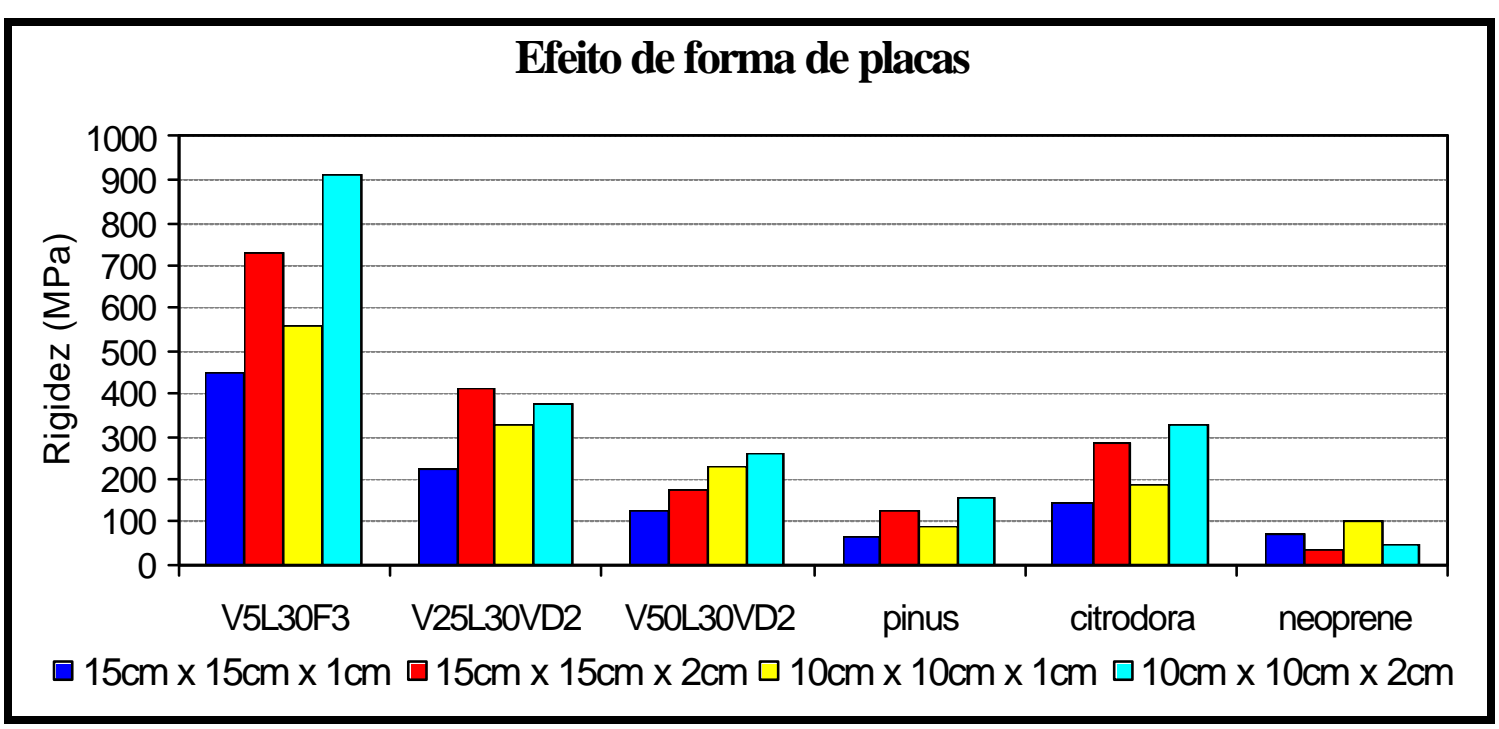

Figura 4.45 - Efeito de forma de placas do compósito, madeira e neoprene

Ainda com relação à Figura 4.45, nota-se que a $2^{\mathrm{a}}$ mistura apresenta um resultado um pouco distinto dos demais, já que para a almofada de espessura $2 \mathrm{~cm}$, obteve-se maior rigidez quando se tinha área da base maior, o que não ocorreu nos outros casos. 


\subsubsection{Ensaio de carga localizada}

Neste capítulo, apresentar-se-ão os resultados médios dos afundamentos de cada um dos 11 traços especificados para este tipo de ensaio na Tabela 3.11 do capítulo 3.5.3.

Como dito naquele capítulo, este ensaio foi realizado no intuito de avaliar a capacidade de acomodar imperfeições por parte das almofadas do compósito em estudo.

$\mathrm{Na}$ sequiência, serão apresentados os cálculos e resultados após ensaio de afundamento do traço V5L30F2 para 2 placas de espessura $5 \mathrm{~mm}$.

Inicialmente, as 2 placas de $15 \mathrm{~cm}$ x $15 \mathrm{~cm}$ são divididas em 6 partes menores de $2,5 \mathrm{~cm}$ x $15 \mathrm{~cm}$ cada uma, totalizando 12 partes, das quais 2 são destinadas à aplicação de carga para verificação da carga máxima a ser aplicada e as outras 10 partes são destinadas à avaliação do afundamento em 4 pontos distintos, conforme descrito no capítulo 3.5.3. Na Tabela 4.10 constam as cargas de ruptura das 2 fatias da placa ensaiadas à compressão e a média entre as duas cargas, sendo obtida a carga de ruptura a ser aplicada nas demais fatias da placa.

Tabela 4.10 - Carga de ruptura da placa $(\mathrm{kN})$

\begin{tabular}{||c|c|c||}
\hline \multicolumn{3}{|c||}{ Carga de ruptura $(\mathrm{kN})$} \\
\hline $\mathbf{1}^{\mathbf{a}}$ fatia & $\mathbf{2}^{\mathbf{a}}$ fatia & Média \\
\hline 19,5 & 20,5 & $\mathbf{2 0 , 0}$ \\
\hline
\end{tabular}

A Tabela 4.11 apresenta os valores medidos com o paquímetro em cada um dos 4 pontos antes da aplicação da carga e após a aplicação de metade da carga de ruptura e, em seguida, da carga de ruptura.

A partir das medidas iniciais, após aplicação de 50\% da carga de ruptura e após aplicação da carga de ruptura pode-se calcular as diferenças $x-a, y-b, z-c$ e $w-d$ para se obter o afundamento de cada um dos pontos para metade da carga de ruptura e as diferenças $x-e, y-f, z-g$ e $w-h$ para se obter o afundamento de cada um dos pontos para a carga de ruptura. Calculado o afundamento de cada um dos pontos das 10 fatias, pode-se aplicar o critério de Chauvenet e, calcular, então, o afundamento médio para metade da carga de ruptura e para a carga de ruptura. Isso é feito calculando-se a média de todos os resultados. A seguir, calcula-se o desvio padrão e verificam-se os valores 
que se encontram dentro do intervalo deste desvio multiplicado pela média, calculandose, com estes, uma nova média, que corresponderá ao afundamento da almofada, conforme se pode observar na Tabela 4.12. Calcula-se, da mesma forma, o afundamento em porcentagem, o qual é apresentado na Tabela 4.13.

Tabela 4.11 - Medidas dos 4 pontos da placa antes e depois da aplicação da carga

\begin{tabular}{|c|c|c|c|c|c|c|c|c|c|c|c|c||}
\hline \multirow{2}{*}{$\begin{array}{c}\text { Fatia } \\
\mathbf{n}^{\mathbf{0}}\end{array}$} & \multicolumn{4}{|c|}{$\begin{array}{c}\text { Medidas iniciais } \\
\mathbf{( m m} \text { ) }\end{array}$} & \multicolumn{4}{c|}{$\begin{array}{c}\text { Medidas - 50\% da } \\
\text { Carga de Ruptura }\end{array}$} & \multicolumn{4}{c|}{$\begin{array}{c}\text { Medidas - Carga de } \\
\text { Ruptura }\end{array}$} \\
\cline { 2 - 15 } & $\mathbf{x}$ & $\mathbf{y}$ & $\mathbf{z}$ & $\mathbf{w}$ & $\mathbf{a}$ & $\mathbf{b}$ & $\mathbf{c}$ & $\mathbf{d}$ & $\mathbf{e}$ & $\mathbf{f}$ & $\mathbf{g}$ & $\mathbf{h}$ \\
\hline $\mathbf{1}$ & 5,87 & 6,07 & 5,77 & 5,39 & 5,79 & 6,05 & 5,50 & 5,37 & 5,54 & 5,68 & 5,10 & 5,30 \\
\hline $\mathbf{2}$ & 6,08 & 6,04 & 5,36 & 5,33 & 5,91 & 6,00 & 5,23 & 5,24 & 5,51 & 5,98 & 4,87 & 5,29 \\
\hline $\mathbf{3}$ & 6,13 & 6,27 & 5,86 & 6,03 & 6,04 & 6,24 & 5,79 & 6,03 & 5,87 & 5,97 & 5,47 & 5,73 \\
\hline $\mathbf{4}$ & 5,36 & 5,27 & 5,48 & 5,07 & 5,28 & 5,27 & 5,13 & 5,07 & 4,76 & 4,89 & 4,74 & 5,03 \\
\hline $\mathbf{5}$ & 5,43 & 5,28 & 5,27 & 5,56 & 5,15 & 5,28 & 5,21 & 5,55 & 4,72 & 5,09 & 5,01 & 5,30 \\
\hline $\mathbf{6}$ & 6,13 & 5,83 & 5,34 & 5,36 & 5,95 & 5,83 & 5,26 & 5,34 & 5,68 & 5,56 & 4,90 & 4,95 \\
\hline $\mathbf{7}$ & 6,70 & 6,70 & 6,74 & 6,78 & 6,63 & 6,69 & 6,64 & 6,78 & 6,45 & 6,56 & 6,40 & 6,61 \\
\hline $\mathbf{8}$ & 6,70 & 6,66 & 6,52 & 6,50 & 6,60 & 6,64 & 6,40 & 6,50 & 6,00 & 6,55 & 5,91 & 6,41 \\
\hline $\mathbf{9}$ & 5,93 & 6,07 & 5,45 & 5,81 & 5,78 & 6,07 & 5,41 & 5,79 & 5,57 & 5,84 & 5,40 & 5,78 \\
\hline $\mathbf{1 0}$ & 5,39 & 5,09 & 6,01 & 6,04 & 5,19 & 5,05 & 5,78 & 6,02 & 4,71 & 5,02 & 5,40 & 5,77 \\
\hline
\end{tabular}

Tabela 4.12 - Afundamento médio da almofada (mm)

\begin{tabular}{|c|c|c|c|c|c|c|c|c||}
\hline \multirow{2}{*}{$N^{\mathbf{o}}$ fatia } & \multicolumn{3}{|c|}{$\begin{array}{c}\text { Afundamento para 50\% da carga } \\
\text { de ruptura }\end{array}$} & \multicolumn{4}{|c|}{$\begin{array}{c}\text { Afundamento para carga de } \\
\text { ruptura }\end{array}$} \\
\cline { 2 - 9 } & $\mathbf{x}^{\prime}$ & $\mathbf{y}^{\prime}$ & $\mathbf{z}^{\prime}$ & $\mathbf{w}^{\prime}$ & $\mathbf{x}^{\prime \prime}$ & $\mathbf{y}^{\prime \prime}$ & $\mathbf{z}^{\prime \prime}$ & $\mathbf{w}^{\prime \prime}$ \\
\hline 1 & 0,0800 & 0,0200 & 0,2700 & 0,0200 & 0,3300 & 0,3900 & 0,6700 & 0,0900 \\
\hline 2 & 0,1700 & 0,0400 & 0,1300 & 0,0900 & 0,5700 & 0,0600 & 0,4900 & 0,0400 \\
\hline 3 & 0,0900 & 0,0300 & 0,0700 & 0,0000 & 0,2600 & 0,3000 & 0,3900 & 0,3000 \\
\hline 4 & 0,0800 & 0,0000 & 0,3500 & 0,0000 & 0,6000 & 0,3800 & 0,7400 & 0,0400 \\
\hline 5 & 0,2800 & 0,0000 & 0,0600 & 0,0100 & 0,7100 & 0,1900 & 0,2600 & 0,2600 \\
\hline 6 & 0,1800 & 0,0000 & 0,0800 & 0,0200 & 0,4500 & 0,2700 & 0,4400 & 0,4100 \\
\hline 7 & 0,0700 & 0,0100 & 0,1000 & 0,0000 & 0,2500 & 0,1400 & 0,3400 & 0,1700 \\
\hline 8 & 0,1000 & 0,0200 & 0,1200 & 0,0000 & 0,7000 & 0,1100 & 0,6100 & 0,0900 \\
\hline 9 & 0,1500 & 0,0000 & 0,0400 & 0,0200 & 0,3600 & 0,2300 & 0,0500 & 0,0300 \\
\hline 10 & 0,2000 & 0,0400 & 0,2300 & 0,0200 & 0,6800 & 0,0700 & 0,6100 & 0,2700 \\
\hline média & $\mathbf{0 , 1 4 0 0}$ & $\mathbf{0 , 0 1 6 0}$ & $\mathbf{0 , 1 4 5 0}$ & $\mathbf{0 , 0 1 8 0}$ & $\mathbf{0 , 4 9 1 0}$ & $\mathbf{0 , 2 1 4 0}$ & $\mathbf{0 , 4 6 0 0}$ & $\mathbf{0 , 1 7 0 0}$ \\
\hline
\end{tabular}


Tabela 4.13 - Afundamento médio percentual da almofada (\%)

\begin{tabular}{|c|c|c|c|c|c|c|c|c||}
\hline \multirow{2}{*}{$\begin{array}{c}\text { Fatia } \\
\mathbf{n}^{\mathbf{0}}\end{array}$} & \multicolumn{3}{|c|}{$\begin{array}{c}\text { Afundamento para } \mathbf{5 0 \%} \text { da carga } \\
\text { de ruptura }\end{array}$} & \multicolumn{4}{|c||}{$\begin{array}{c}\text { Afundamento para carga de } \\
\text { ruptura }\end{array}$} \\
\cline { 2 - 9 } & $\mathbf{\mathbf { x } ^ { \prime }}$ & $\mathbf{y}^{\prime}$ & $\mathbf{z}^{\prime}$ & $\mathbf{w}^{\prime}$ & $\mathbf{x}^{\prime \prime}$ & $\mathbf{y}^{\prime \prime}$ & $\mathbf{z}^{\prime \prime}$ & $\mathbf{w}^{\prime \prime}$ \\
\hline 1 & $1,36 \%$ & $0,33 \%$ & $4,68 \%$ & $0,37 \%$ & $5,62 \%$ & $6,43 \%$ & $11,61 \%$ & $1,67 \%$ \\
\hline 2 & $2,80 \%$ & $0,66 \%$ & $2,43 \%$ & $1,69 \%$ & $9,38 \%$ & $0,99 \%$ & $9,14 \%$ & $0,75 \%$ \\
\hline 3 & $1,47 \%$ & $0,48 \%$ & $1,19 \%$ & $0,00 \%$ & $4,24 \%$ & $4,78 \%$ & $6,66 \%$ & $4,98 \%$ \\
\hline 4 & $1,49 \%$ & $0,00 \%$ & $6,39 \%$ & $0,00 \%$ & $11,19 \%$ & $7,21 \%$ & $13,50 \%$ & $0,79 \%$ \\
\hline 5 & $5,16 \%$ & $0,00 \%$ & $1,14 \%$ & $0,18 \%$ & $13,08 \%$ & $3,60 \%$ & $4,93 \%$ & $4,68 \%$ \\
\hline 6 & $2,94 \%$ & $0,00 \%$ & $1,50 \%$ & $0,37 \%$ & $7,34 \%$ & $4,63 \%$ & $8,24 \%$ & $7,65 \%$ \\
\hline 7 & $1,04 \%$ & $0,15 \%$ & $1,48 \%$ & $0,00 \%$ & $3,73 \%$ & $2,09 \%$ & $5,04 \%$ & $2,51 \%$ \\
\hline 8 & $1,49 \%$ & $0,30 \%$ & $1,84 \%$ & $0,00 \%$ & $10,45 \%$ & $1,65 \%$ & $9,36 \%$ & $1,38 \%$ \\
\hline 9 & $2,53 \%$ & $0,00 \%$ & $0,73 \%$ & $0,34 \%$ & $6,07 \%$ & $3,79 \%$ & $0,92 \%$ & $0,52 \%$ \\
\hline 10 & $3,71 \%$ & $0,79 \%$ & $3,83 \%$ & $0,33 \%$ & $12,62 \%$ & $1,38 \%$ & $10,15 \%$ & $4,47 \%$ \\
\hline média & $\mathbf{2 , 4 0 \%}$ & $\mathbf{0 , 2 7 \%}$ & $\mathbf{2 , 5 2 \%}$ & $\mathbf{0 , 3 3 \%}$ & $\mathbf{8 , 3 7 \%}$ & $\mathbf{3 , 6 5 \%}$ & $\mathbf{7 , 9 6 \%}$ & $\mathbf{2 , 9 4 \%}$ \\
\hline
\end{tabular}

Ao se aplicar o critério de Chauvenet nos resultados das Tabelas 4.12 e 4.13, há alguns valores que foram desprezados em razão da grande dispersão dos mesmos, como é o caso dos dois últimos valores de afundamento para carga de ruptura da fatia de número 9 e também do último valor da fatia de número 2. Lembrando que esse procedimento também é adotado para as demais fatias e traços.

Para cálculo do afundamento médio para metade da carga de ruptura e para carga de ruptura basta calcular, respectivamente, as médias entre (x', y',z'e w' em seus valores médios) e (x", y", z"e w" em seus valores médios), tanto para o caso do afundamento em mm (Tabela 4.12) como para o afundamento em porcentagem (Tabela 4.13), levando em conta o desvio padrão da média de cada um. $\mathrm{O}$ afundamento médio da placa de $5 \mathrm{~mm}$ de espessura moldada com 5\% de vermiculita, $30 \%$ de látex e $2 \%$ de fibra de PVA (V5L30F2) consta na Tabela 4.14, tanto com seu valor em $\mathrm{mm}$ como em $\%$ e onde $P$ corresponde à carga de ruptura.

Tabela 4.14 - Afundamento das placas para o traço V5L30F2

\begin{tabular}{||c|c|c|c||}
\hline \multicolumn{2}{||c|}{$\begin{array}{c}\text { Afundamento médio } \\
(\mathrm{mm})\end{array}$} & \multicolumn{2}{|c|}{$\begin{array}{c}\text { Afundamento médio } \\
(\%)\end{array}$} \\
\hline $\mathbf{P} / 2$ & $\mathbf{P}$ & $\mathbf{P} / 2$ & $\mathbf{P}$ \\
\hline $\mathbf{0 , 0 6 9 0}$ & $\mathbf{0 , 2 8 6 5}$ & $\mathbf{1 , 3 8}$ & $\mathbf{5 , 7 3}$ \\
\hline
\end{tabular}


Para as outras duas espessuras $(10$ e $20 \mathrm{~mm})$ os cálculos foram efetuados da mesma forma como foram expostos para a espessura de $5 \mathrm{~mm}$, assim como se adotou o mesmo procedimento para os demais traços, cujos resultados finais são mostrados na sequiência.

Nas Tabelas 4.15 e 4.16, pode-se verificar os resultados dos afundamentos médios para cada espessura e traços ensaiados. Nessa tabela, a letra $\mathbf{P}$ representa a carga de ruptura de cada espessura de placa. Nas tabelas constam, portanto, os afundamentos médios para a carga de ruptura e para metade dessa carga das placas de cada traço moldado. Como dito no capítulo de descrição deste ensaio, a carga é aplicada em quatro pontos de cada uma das fatias de $2,5 \mathrm{~cm}$ de largura e é feita a depuração dos resultados dos afundamentos de cada um dos quatro pontos para se ter o afundamento médio de uma dada fatia. Essa depuração estatística foi realizada utilizando-se o critério de Chauvenet, que também foi utilizado na determinação da média entre as médias das fatias para se obter, finalmente, o afundamento médio de cada traço, conforme pode ser visualizado nas Tabelas 4.15 e 4.16 .

Tabela 4.15 - Afundamento em placas de $15 \mathrm{~cm}$ x $15 \mathrm{~cm}$ - Valores absolutos

\begin{tabular}{||c|c|c|c|c|c|c||}
\hline \multirow{2}{*}{ Traços } & \multicolumn{5}{|c|}{ Afundamento médio de cada placa (mm) } \\
\cline { 2 - 7 } & $\mathbf{5 0 \%}$ da Carga de Ruptura & \multicolumn{3}{c||}{ Carga de Ruptura (P) } \\
\cline { 2 - 7 } & $\mathbf{e}=\mathbf{5 m m}$ & $\mathbf{e}=\mathbf{1 0 m m}$ & $\mathbf{e}=\mathbf{2 0 m m}$ & $\mathbf{e}=\mathbf{5 m m}$ & $\mathbf{e}=\mathbf{1 0 m m}$ & e = 20mm \\
\hline V0L0F0 & 0,0175 & 0,0190 & 0,0140 & 0,0315 & 0,0370 & 0,0480 \\
\hline V0L30F3 & 0,0885 & 0,1000 & 0,1180 & 0,2990 & 0,3730 & 0,6680 \\
\hline V5L30F2 & 0,0690 & 0,0790 & 0,0540 & 0,2865 & 0,3690 & 0,4940 \\
\hline V5L30F3 & 0,1235 & 0,1100 & 0,1460 & 0,3195 & 0,6110 & 0,7100 \\
\hline V5L30F4 & 0,1765 & 0,2550 & 0,2280 & 0,4270 & 0,8500 & 1,2480 \\
\hline V10L30F3 & 0,1754 & 0,1324 & 0,1958 & 0,3107 & 0,8953 & 0,7165 \\
\hline V25L30F2 & 0,2990 & 0,3100 & 0,2340 & 0,7530 & 1,4310 & 1,4160 \\
\hline V5L30VD2 & 0,0765 & 0,0640 & 0,0480 & 0,3160 & 0,5730 & 0,6620 \\
\hline V25L30VD2 & 0,2925 & 0,3210 & 0,2520 & 0,7405 & 1,2660 & 1,5680 \\
\hline V50L30VD2 & 0,5850 & 0,5540 & 0,4200 & 1,2860 & 2,2650 & 2,0680 \\
\hline V5L30PP2 & 0,0635 & 0,0770 & 0,0520 & 0,2605 & 0,3110 & 0,4020 \\
\hline \hline
\end{tabular}


Tabela 4.16 - Afundamento percentual em placas de $15 \mathrm{~cm} \times 15 \mathrm{~cm}$

\begin{tabular}{||c|c|c|c|c|c|c||}
\hline \multirow{2}{*}{ Traços } & \multicolumn{4}{|c|}{ Afundamento percentual de cada placa (\%) } \\
\cline { 2 - 7 } & $\mathbf{5 0 \%}$ da Carga de Ruptura & \multicolumn{3}{c||}{ Carga de Ruptura (P) } \\
\cline { 2 - 7 } & $\mathbf{e}=\mathbf{5 m m}$ & $\mathbf{e}=\mathbf{1 0 m m}$ & $\mathrm{e}=\mathbf{2 0 m m}$ & $\mathrm{e}=\mathbf{5 m m}$ & $\mathrm{e}=\mathbf{1 0 m m}$ & $\mathrm{e}=\mathbf{2 0 \mathrm { mm }}$ \\
\hline V0L0F0 & $0,35 \%$ & $0,19 \%$ & $0,07 \%$ & $0,63 \%$ & $0,37 \%$ & $0,24 \%$ \\
\hline V0L30F3 & $1,77 \%$ & $1,00 \%$ & $0,59 \%$ & $5,98 \%$ & $3,73 \%$ & $3,34 \%$ \\
\hline V5L30F2 & $1,38 \%$ & $0,79 \%$ & $0,27 \%$ & $5,73 \%$ & $3,69 \%$ & $2,47 \%$ \\
\hline V5L30F3 & $2,47 \%$ & $1,10 \%$ & $0,73 \%$ & $6,39 \%$ & $6,11 \%$ & $3,55 \%$ \\
\hline V5L30F4 & $3,53 \%$ & $2,55 \%$ & $1,14 \%$ & $8,54 \%$ & $8,50 \%$ & $6,24 \%$ \\
\hline V10L30F3 & $3,51 \%$ & $1,32 \%$ & $0,98 \%$ & $6,21 \%$ & $8,95 \%$ & $3,58 \%$ \\
\hline V25L30F2 & $5,98 \%$ & $3,10 \%$ & $1,17 \%$ & $15,06 \%$ & $14,31 \%$ & $7,08 \%$ \\
\hline V5L30VD2 & $1,53 \%$ & $0,64 \%$ & $0,24 \%$ & $6,32 \%$ & $5,73 \%$ & $3,31 \%$ \\
\hline V25L30VD2 & $5,85 \%$ & $3,21 \%$ & $1,26 \%$ & $14,81 \%$ & $12,66 \%$ & $7,84 \%$ \\
\hline V50L30VD2 & $11,70 \%$ & $5,54 \%$ & $2,10 \%$ & $25,72 \%$ & $22,65 \%$ & $10,34 \%$ \\
\hline V5L30PP2 & $1,27 \%$ & $0,77 \%$ & $0,26 \%$ & $5,21 \%$ & $3,11 \%$ & $2,01 \%$ \\
\hline \hline
\end{tabular}

Ao se comparar o traço de referência (V0L0F0) com os demais traços, nota-se que seu afundamento é bastante inferior ao de todos os outros traços, além de sofrer ruptura frágil e a uma carga bastante inferior à carga de ruptura das almofadas do compósito. Mesmo as almofadas menos macias do compósito, V0L30F3 e V5L30F2, que são aquelas que tiveram menor afundamento, possuíram afundamento de 4 a 5 vezes maior que o afundamento sofrido pela argamassa simples na presença de carga pontual de compressão e, além disso, não sofreram ruptura frágil (brusca), apresentando maior capacidade de acomodar imperfeições.

Notou-se que o maior afundamento percentual ocorreu para a mistura de traço V50L30VD2 (Figura 4.46 e Tabelas 4.15 e 4.16), sendo bem maior que o afundamento percentual ocorrido para todos os outros traços. As placas com traço V25L30VD2 possuíam afundamento da ordem de 50\% a 60\% do afundamento obtido para V50L30VD2, porém esse afundamento ainda é bastante superior ao de todas as outras misturas. Portanto, à medida que se acrescentava vermiculita, o afundamento da placa aumentava gradativamente, a placa se tornava cada vez mais macia. 
Tabela 4.17 - Força de ruptura e afundamento em placas de $15 \mathrm{~cm} \times 15 \mathrm{~cm}$

\begin{tabular}{||c|c|c|c|c|c|c||}
\hline \multirow{2}{*}{ Traço } & \multicolumn{3}{|c|}{ Carga de Ruptura (P) } & \multicolumn{3}{c||}{ P/afundamento (kN/mm) } \\
\cline { 2 - 8 } & $\mathrm{e}=\mathbf{5 m m}$ & $\mathrm{e}=\mathbf{1 0 m m}$ & $\mathrm{e}=\mathbf{2 0 \mathbf { m m }}$ & $\mathrm{e}=\mathbf{5 m m}$ & $\mathrm{e}=\mathbf{1 0 m m}$ & $\mathrm{e}=\mathbf{2 0 \mathbf { m m }}$ \\
\hline V0L0F0 & 11,00 & 10,50 & 9,50 & 349 & 284 & 198 \\
\hline V0L30F3 & 31,00 & 30,00 & 28,00 & 104 & 80 & 42 \\
\hline V5L30F2 & 21,00 & 20,50 & 20,00 & 73 & 56 & 40 \\
\hline V5L30F3 & 22,50 & 21,50 & 21,00 & 70 & 35 & 30 \\
\hline V5L30F4 & 25,50 & 25,00 & 24,00 & 60 & 29 & 19 \\
\hline V10L30F3 & 19,00 & 18,25 & 17,50 & 61 & 20 & 24 \\
\hline V25L30F2 & 13,00 & 11,00 & 10,00 & 17 & 8 & 7 \\
\hline V5L30VD2 & 21,25 & 20,50 & 19,50 & 67 & 36 & 29 \\
\hline V25L30VD2 & 16,00 & 15,00 & 13,50 & 22 & 12 & 9 \\
\hline V50L30VD2 & 8,75 & 8,25 & 7,50 & 7 & 4 & 4 \\
\hline V5L30PP2 & 21,20 & 20,40 & 19,80 & 64 & 34 & 31 \\
\hline \hline
\end{tabular}

Com relação à carga de ruptura, verifica-se, na Tabela 4.17, que esta é muito maior quando se trata de misturas com pequena quantidade de vermiculita (5\%). Também se nota que quando se utilizam grandes quantidades de vermiculita, sobretudo o caso de $50 \%$ do material, têm-se cargas de ruptura bastante baixas.

Entretanto, quando se avalia força e afundamento em conjunto, nota-se que os maiores valores para a referida relação se concentram nas misturas com pequena quantidade de vermiculita e o que se nota é que um valor mediano fica entre $5 \%$ e $\mathbf{1 5 \%}$ de vermiculita, talvez misturas com $10 \%$ ou $12 \%$.

$\mathrm{Na}$ seqüência, apresentam-se algumas figuras que mostram a relação dos afundamentos para cada mistura.

Na Figura 4.47 pode-se observar o afundamento médio, em valor absoluto, para todos os traços e espessura da almofada de 10mm. Ao se comparar V50L30VD2 (penúltima barra) com V25L30VD2 (antepenúltima barra), nota-se que o afundamento das almofadas com 50\% de vermiculita para a dada espessura é em torno de 2 vezes maior que o afundamento para as almofadas com apenas $25 \%$ do material. Entretanto, ao se observar os mesmos traços, porém para as 3 espessuras $(5,10$ e $20 \mathrm{~mm})$, na Figura 
4.48, nota-se que o afundamento também é praticamente 2 vezes maior para espessura igual a $5 \mathrm{~mm}$ mas não chega a $1,5 \mathrm{vez}$ quando se trata de maior espessura $(20 \mathrm{~mm})$.

\section{Afundamento médio para carga de ruptura (\%)}

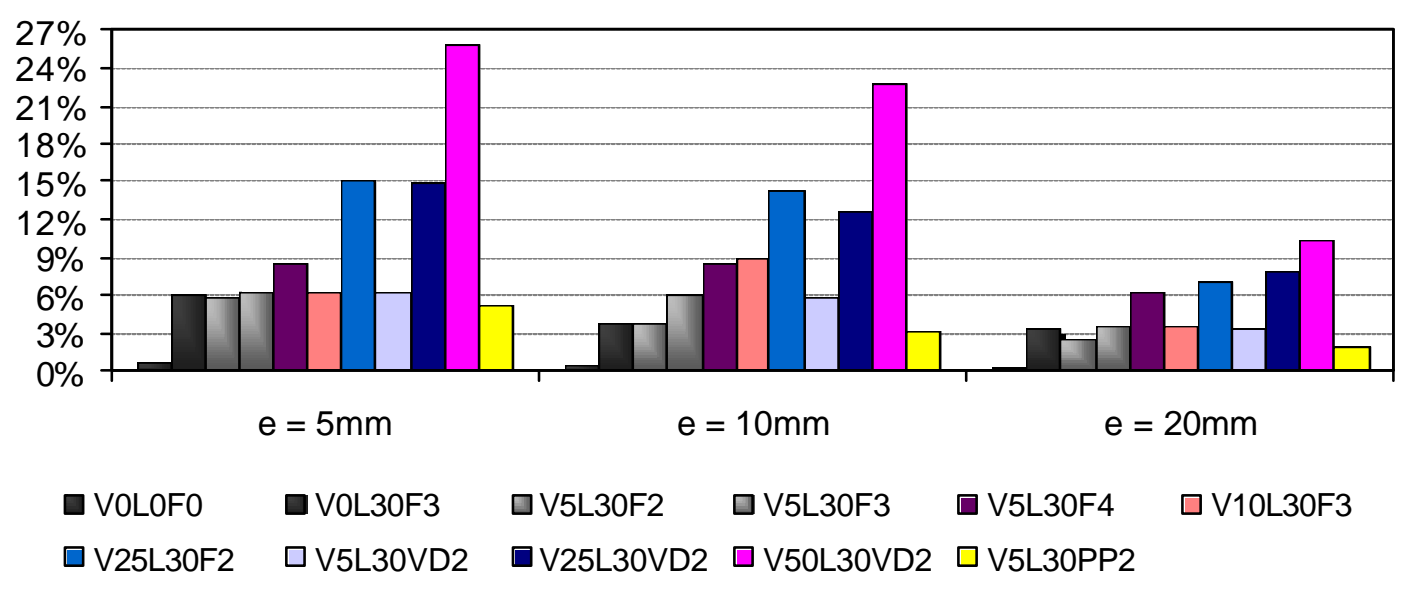

Figura 4.46 - Gráfico de afundamento médio percentual para carga de ruptura

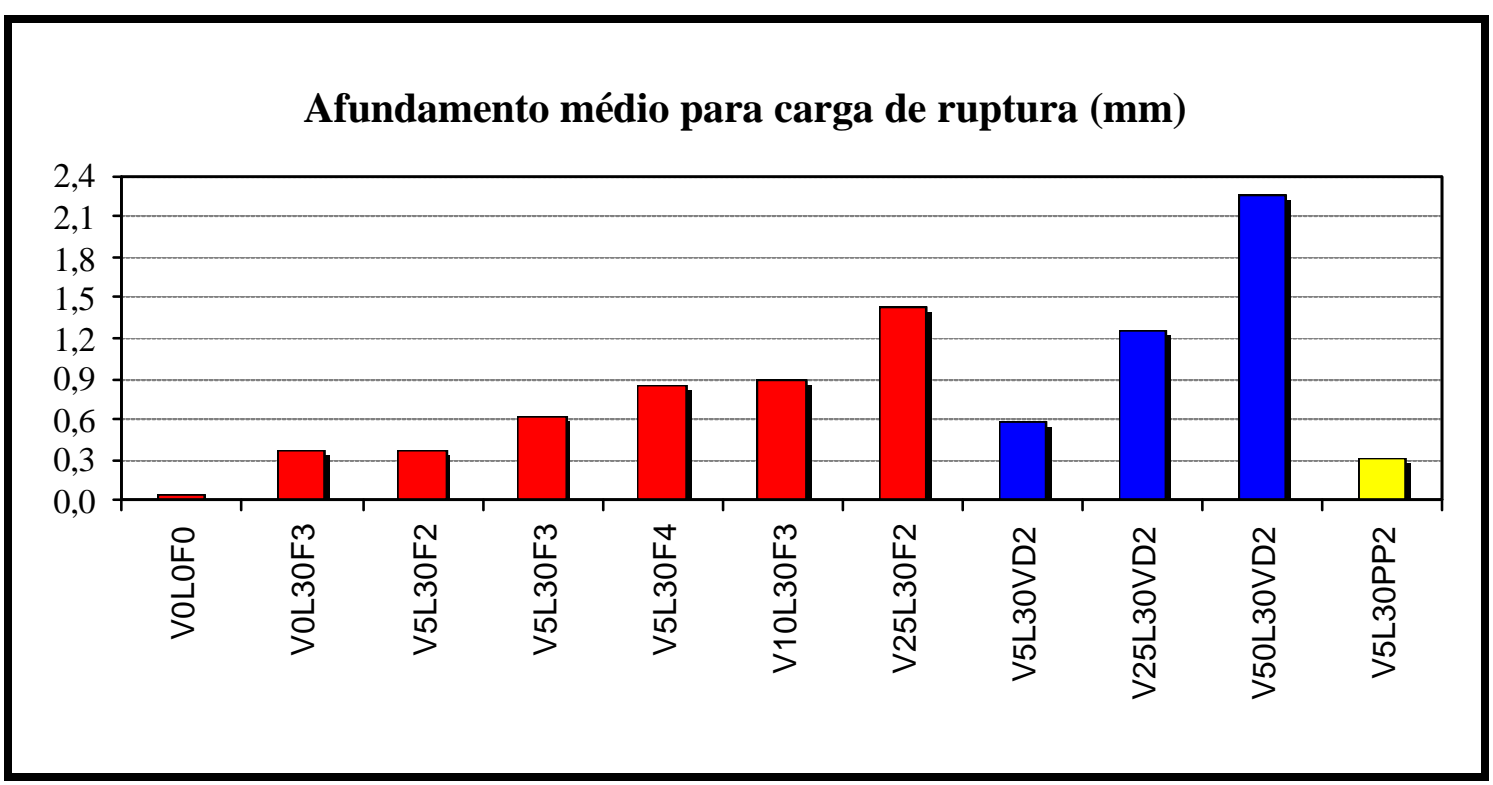

Figura 4.47 - Afundamento médio para carga de ruptura $(\mathrm{e}=10 \mathrm{~mm})$

Ao se comparar $3^{\mathrm{a}}, 6^{\mathrm{a}}$ e $7^{\mathrm{a}}$ barras da Figura 4.47 (V5L30F2, V10L30F3 e V25L30F2, respectivamente), nota-se que um acréscimo de $5 \%$ de vermiculita da $3^{\mathrm{a}}$ para a $6^{\text {a }}$ barra acarreta um afundamento aproximadamente 3 vezes maior, passando de 0,3mm (V5L30F2) para 0,9mm (V10L30F3), entretanto, neste caso, também se deve 
levar em consideração que o segundo traço possui $1 \%$ a mais de fibra de PVA, o que também acarreta em maior afundamento. Para que a comparação melhor realizada, basta comparar os resultados dos traços representados pela $3^{\mathrm{a}}$ e $7^{\mathrm{a}}$ barras da Figura 4.47 , nas quais varia apenas a quantidade de vermiculita. Neste caso, um acréscimo de $20 \%$ de vermiculita teve por conseqüência um aumento do afundamento da ordem de 5, ou seja, o afundamento que era de $0,3 \mathrm{~mm}(\mathrm{~V} 5 \mathrm{~L} 30 \mathrm{~F} 2)$ passou para aproximadamente $1,5 \mathrm{~mm}$ (V25L30F2).

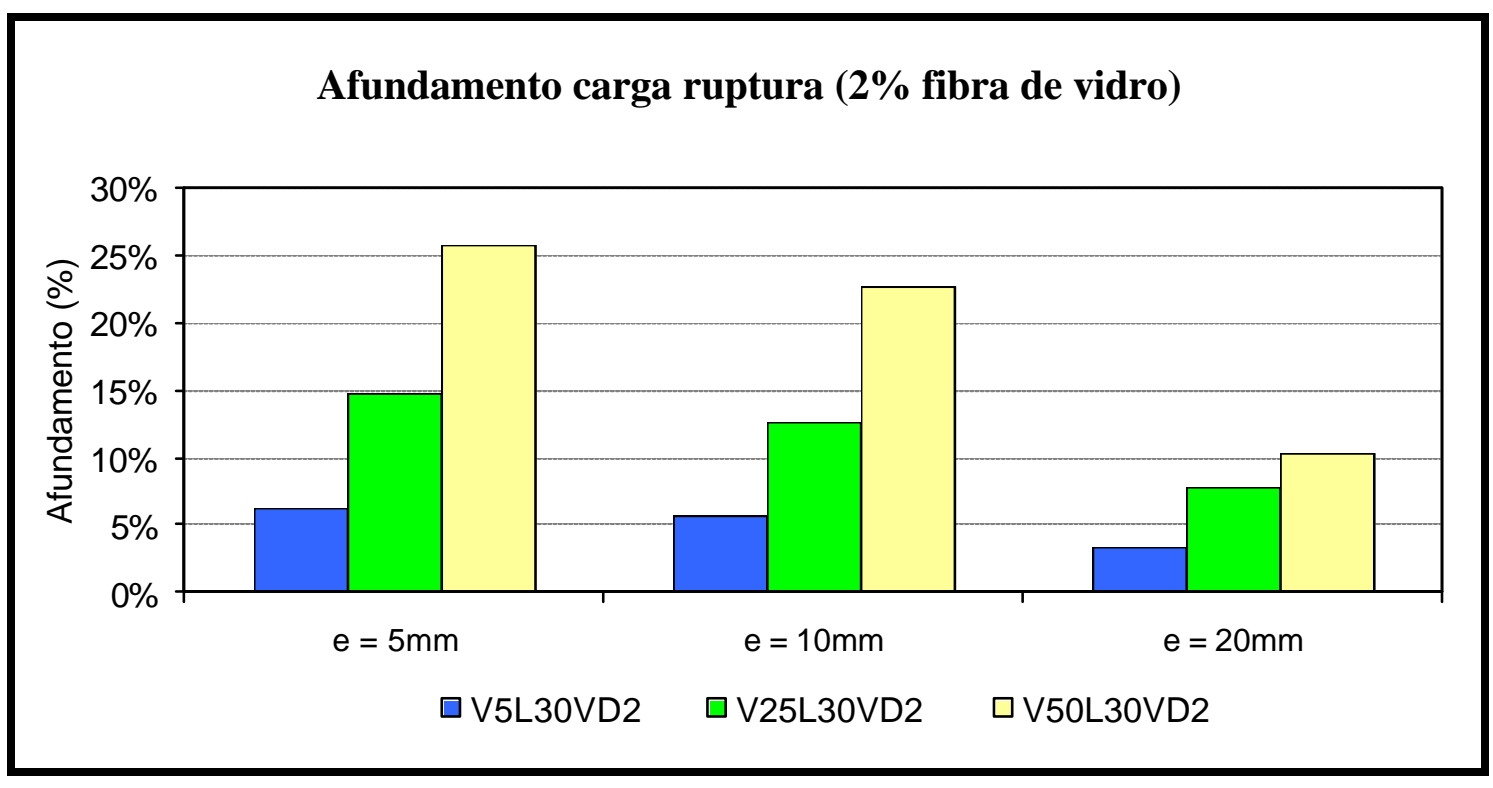

Figura 4.48 -Afundamento da placa ( $2 \%$ de fibra de vidro)

Na Figura 4.48 pode-se observar, de forma clara, a influência da vermiculita nos casos em que se utiliza fibra de vidro. A figura mostra que ao se utilizar uma quantidade muito grande do material, o compósito torna-se bastante mole e, como visto no capítulo de características do compósito, pouco resistente, não sendo ideal de ser utilizado; entretanto, aquele traço com $25 \%$ de vermiculita possui uma resistência de valor médio e também permite um bom afundamento, também pode ser considerado mole, com melhor resistência e constitui um material melhor para ser utilizado como elemento de apoio. Com relação ao V5L30VD2, conclui-se que o mesmo possui elevada resistência, contudo é um pouco duro para ser utilizado como um material de amortecimento.

Mantendo-se a quantidade de vermiculita e aumentando-se a quantidade de fibra de PVA, esse mesmo afundamento tinha seu valor acrescido (Figuras 4.47 e 4.49) e 
também se notou que quanto mais espessa era a placa menor era seu afundamento percentual.

Ao se comparar o afundamento para V5L30F2, V5L30F3 e V5L30F4, para a Figura 4.47, na qual há apenas o afundamento para espessura igual a 10mm, nota-se que para cada acréscimo de $1 \%$ de fibra ocorre um aumento do afundamento da ordem de 0,3mm ( $3 \%$ da espessura da placa), o que mostra a influência do acréscimo de fibras no sentido de permitir um maior afundamento da almofada quando a mesma está submetida à aplicação de carga pontual.

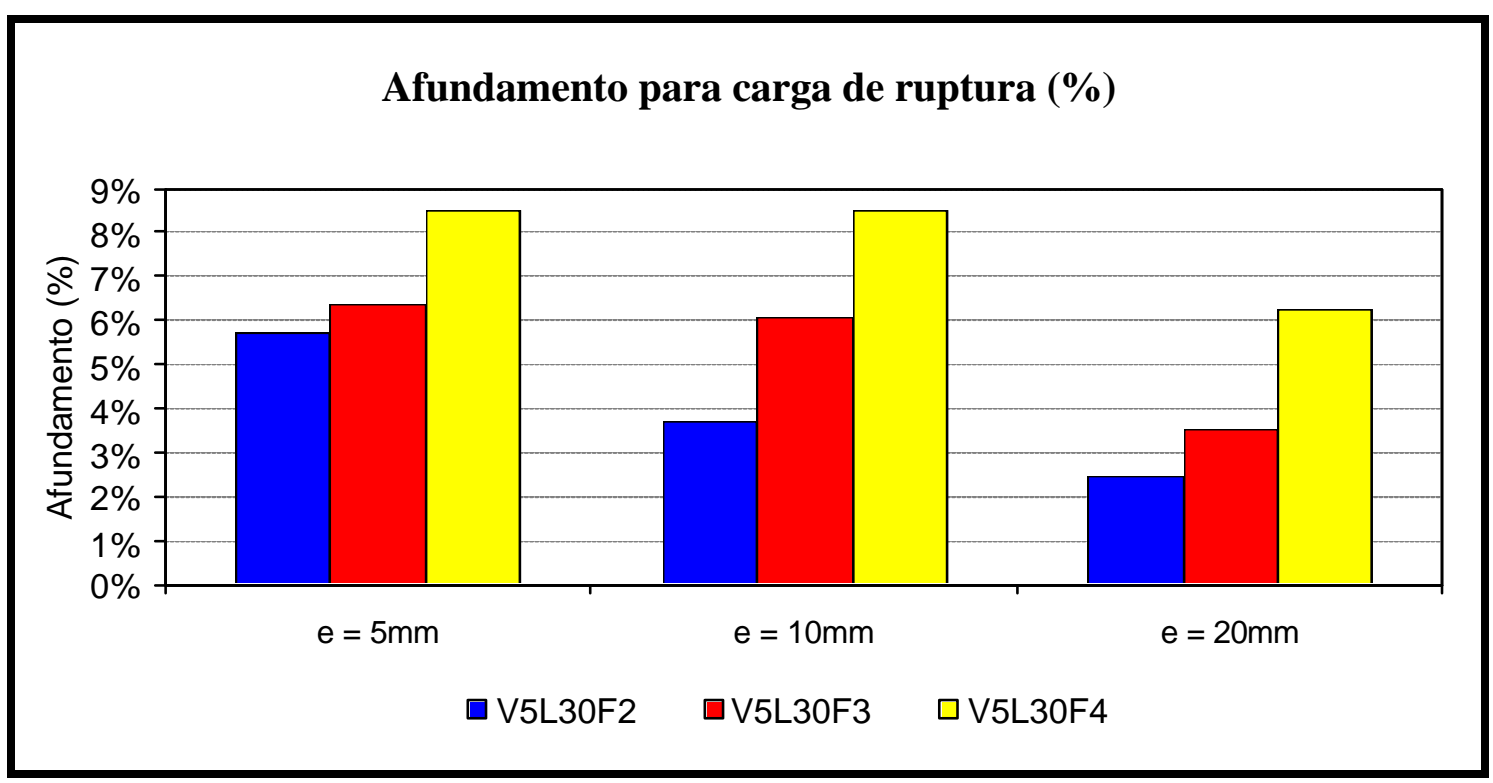

Figura 4.49 -Afundamento da placa (5\% de vermiculita e variando fibra de PVA)

Ao se comparar o afundamento para os 3 tipos de fibra (Figura 4.50), nota-se que os valores são próximos, entretanto cabe destacar que o afundamento percentual é um pouco maior quando se trata da fibra de PVA, a fibra de vidro tem valor intermediário e a de polipropileno apresenta menores valores para afundamento, sobretudo nos casos em que se tem maior espessura $(10 \mathrm{~mm}$ e $20 \mathrm{~mm})$ e se trabalha com pequena quantidade de vermiculita $(5 \%)$. 


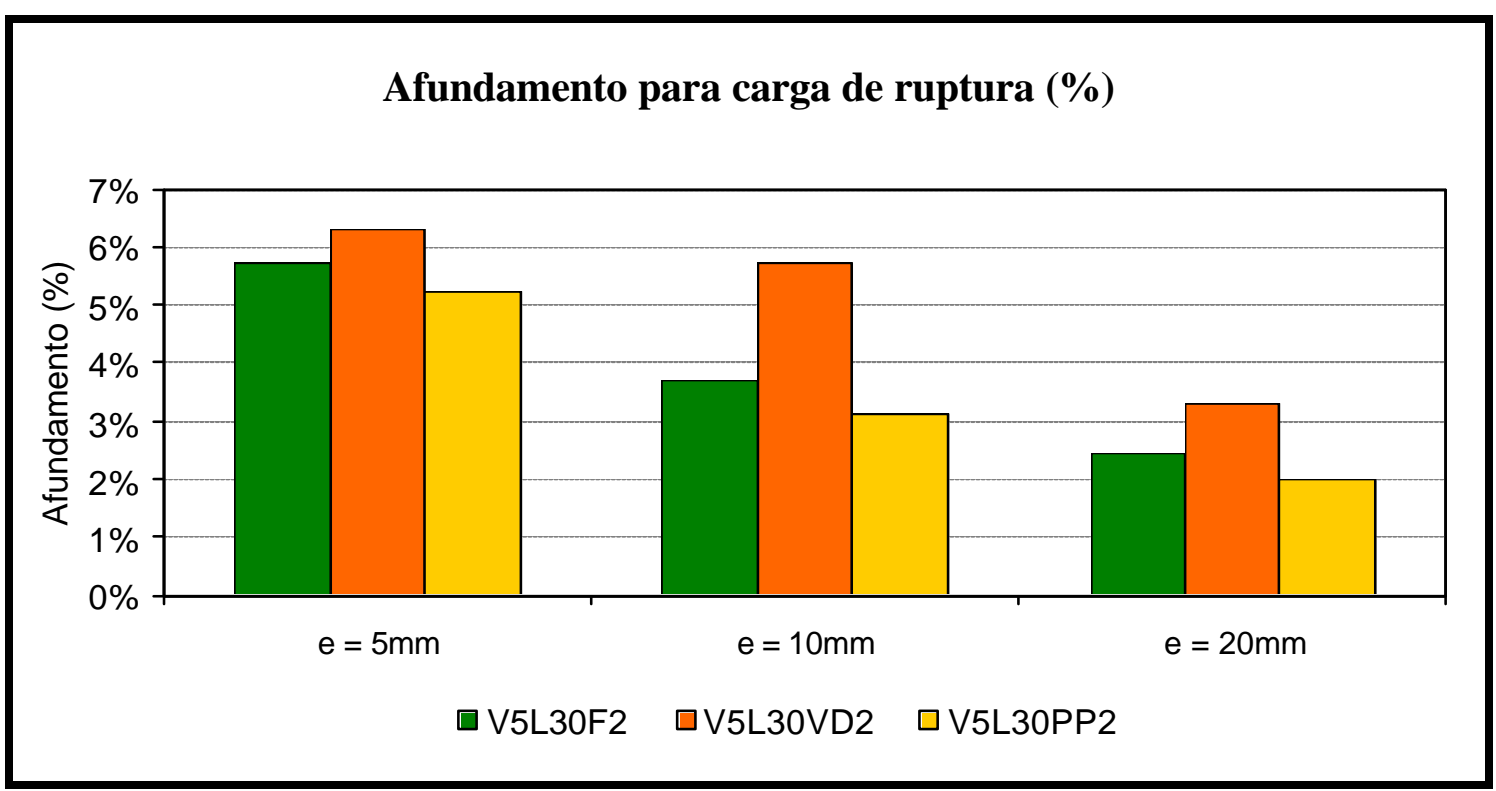

Figura 4.50 -Afundamento da placa (5\% de vermiculita e variando tipo de fibra)

\subsubsection{Análise dos ensaios em almofadas}

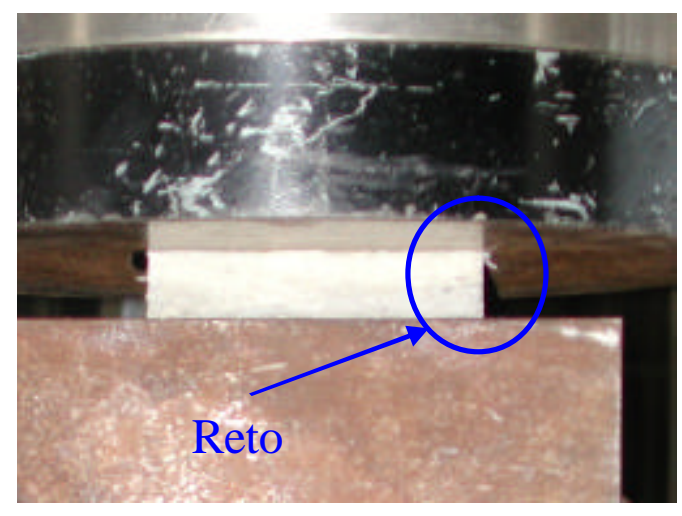

Figura 4.51 - Almofada do compósito

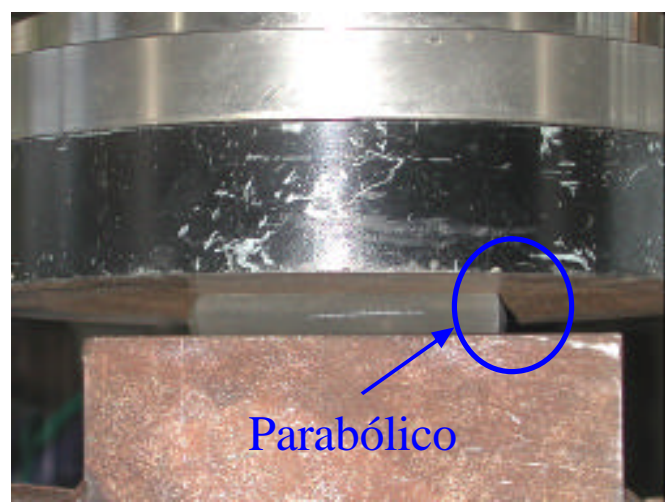

Figura 4.52 - Almofada de neoprene

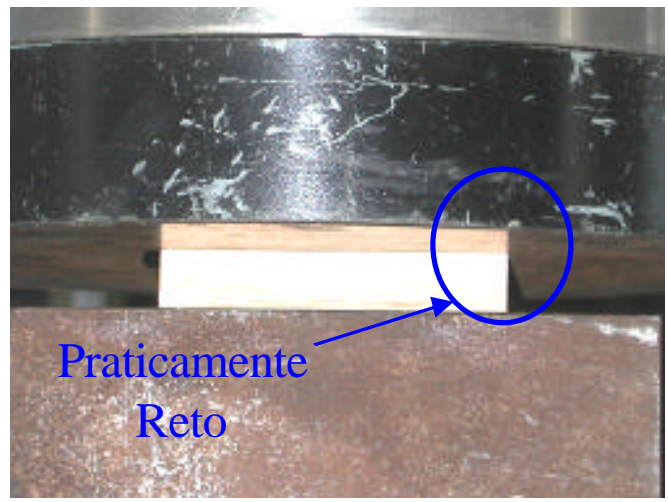

Figura 4.53 - Almofada de madeira (Pinus Taeda) 
Nas Figuras 4.51, 4.52 e 4.53, pode-se verificar algumas características acerca dos ensaios de carga uniforme para obtenção da rigidez de placa.

Analisando-se as Figuras 4.51, 4.52 e 4.53 pode-se notar claramente que a almofada do compósito permanece com sua forma praticamente inalterada (reta) em sua extremidade enquanto a carga é aplicada e ela vai afundando (deformação) ao passo que o neoprene toma uma forma parabólica e vai se deformando mais para cargas bem menores que as cargas do compósito. Já a madeira mole (Pinus) fica com a extremidade praticamente reta e com cargas mais altas que o neoprene, porém menores que as cargas suportadas pelo compósito, além de assumirem forma curva em suas bordas inferior e superior, ao passo que o compósito permite o afundamento, sendo assim, adequado para ser utilizado como elemento de apoio.

Como já se ressaltou que a placa permite um bom afundamento, ilustra-se na seqüência uma Figura (4.54) na qual a placa do compósito de traço V50L30VD2 foi submetida à compressão simples na máquina ELE, sofrendo o processo de estampagem.

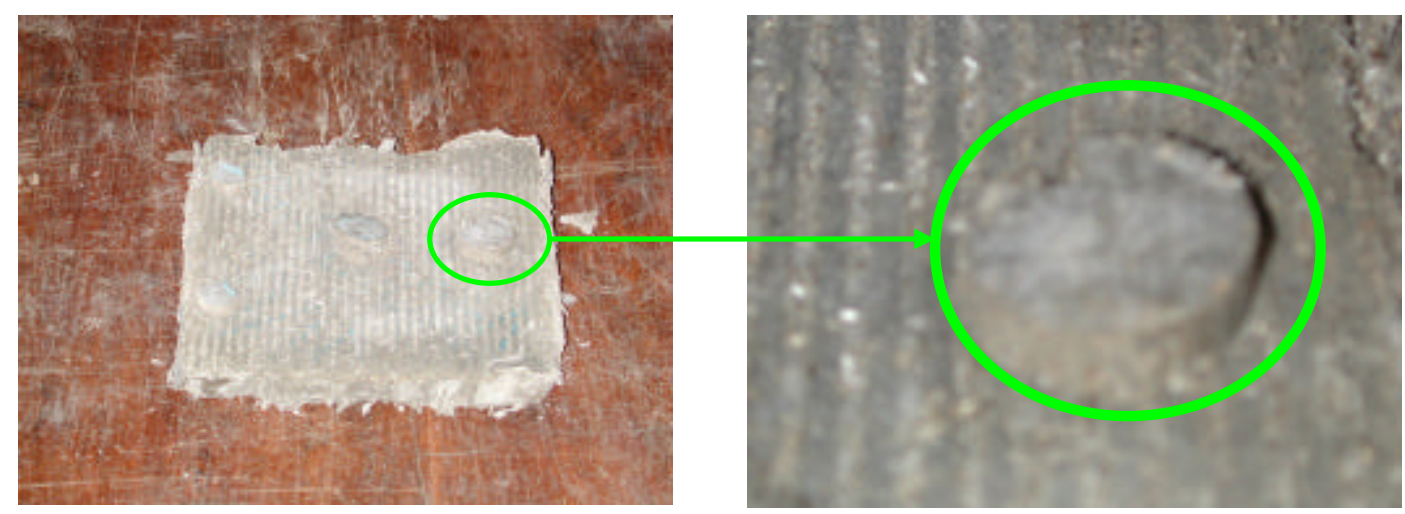

Figura 4.54 - Estampagem de placa do compósito (V50L30VD2)

No caso da Figura 4.54, a placa possui maior quantidade de vermiculita, permitindo ainda maior afundamento, entretanto possui resistência e rigidez menores se comparadas à placa do compósito mostrada na Figura 4.51. Nos ensaios de ligações poderá se observar esses dois traços utilizados entre elementos de concreto e se fará uma melhor análise de suas características como elemento de apoio.

Para melhor visualização do afundamento, são ilustradas as Figuras 4.55, 4.56 e 4.57, nas quais se pode verificar esse mesmo afundamento, contudo, nesse caso, para 
melhor avaliação, observa-se a aplicação de carga pontual, distinguindo a condição de afundamento da placa numa única linha.

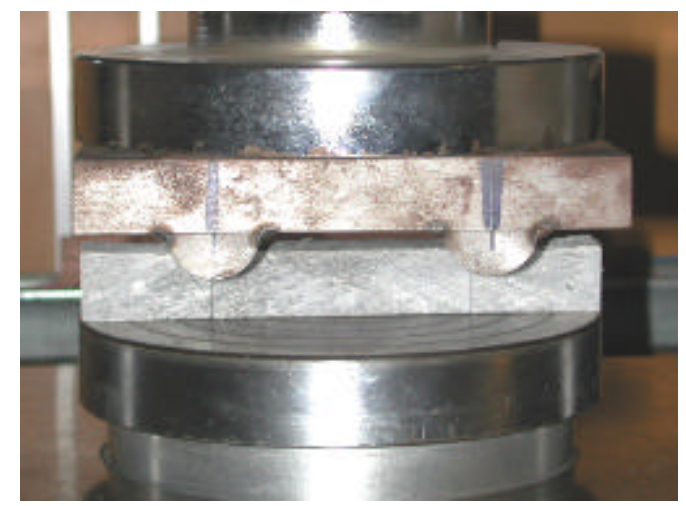

Figura 4.55 - Aplicação de carga em linha para avaliação do afundamento

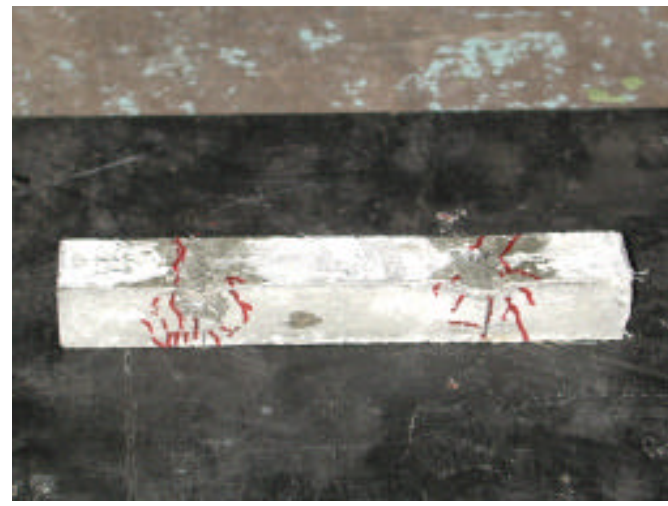

Figura 4.56 - Afundamento de placa de $20 \mathrm{~mm}$ em duas linhas

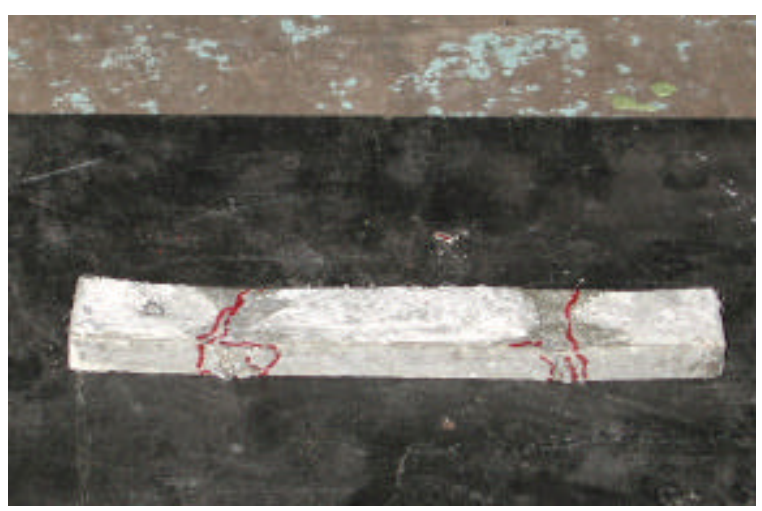

Figura 4.57 - Afundamento de placa de 10mm em duas linhas

Percebe-se que a almofada possui diversas fissuras, mas não se rompe, devido, sobretudo, à presença da fibra que atua como um elemento ligante que cruza as fissuras, interceptando-as. Dessa forma, poderia haver um elemento de concreto imprimindo carga sobre a almofada do compósito que esta afundaria sem, no entanto romper, permitindo a acomodação do elemento que se encontra sobre ela, dada a sua capacidade de acomodar as imperfeições.

Para melhor compreensão acerca dos resultados anteriormente mostrados, estabelecem-se, na seqüência, algumas relações entre as rigidezes e as resistências médias à compressão e o módulo de elasticidade tangente. 
Ao se observar as Figuras 4.58 e 4.59 nota-se que a razão entre a elasticidade tangente e a rigidez é maior quando se utiliza fibra de PVA em se comparada à razão atribuída pela introdução de fibra de vidro ao compósito quando se trata de traços com grande quantidade de vermiculita (25\%); entretanto, quando se utiliza pequena quantidade de vermiculita (5\%), a razão atribuída é praticamente a mesma.

Observa-se também que quanto maior a quantidade de vermiculita empregada no compósito maior é a relação entre $\mathrm{E}$ e $\mathrm{R}$, sobretudo quando se utiliza $50 \%$ de vermiculita.

Nota-se também que as placas maiores (15cm x 15cm) da Figura 4.58 apresentam uma relação $\mathrm{E} / \mathrm{R}$ de 2 a 3 vezes superior à mesma relação para as placas menores $(10 \mathrm{~cm}$ x 10cm) da Figura 4.59 .

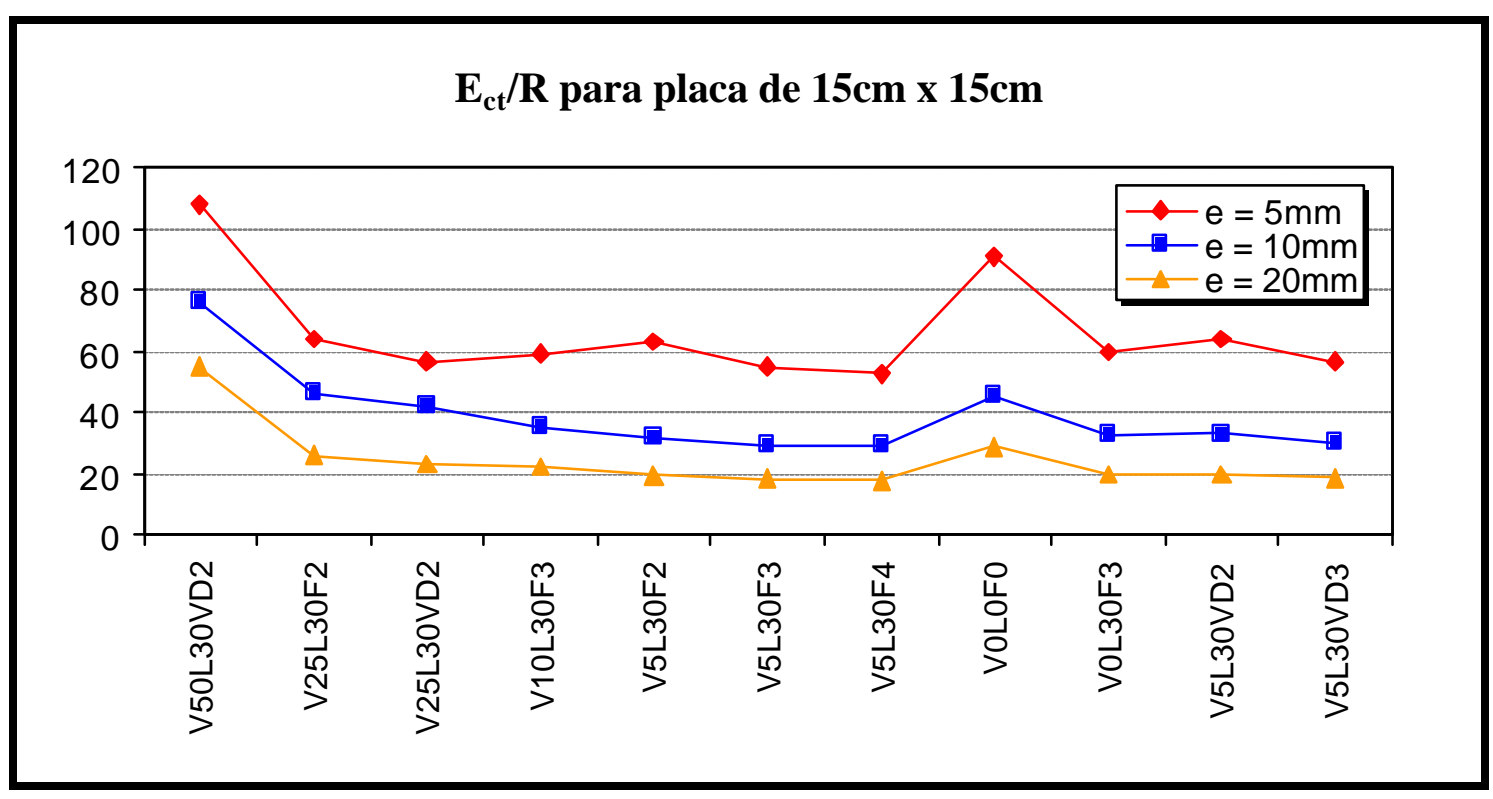

Figura $4.58-\mathrm{E}_{\mathrm{ct}} / \mathrm{R}$ para as placas de $15 \mathrm{~cm} \times 15 \mathrm{~cm}$

Não fica muito claro qual seria a mistura mais adequada neste caso, pois espera-se baixo módulo de elasticidade e também baixa rigidez. No entanto, nota-se que a relaçãa é mais baixa nos casos em que se utiliza pequena quantidade de vermiculita, $\mathbf{5 \%}$.

Observa-se também que quanto maior a espessura menor o valor da razão entre o módulo de elasticidade tangente e a rigidez, sendo que as maiores diferenças ocorrem 
quando se utilizam grandes quantidades do material (50\%) ou quando não se utiliza o material.

Os resultados são semelhantes no caso da elasticidade secante, no entanto apresentam a razão entre a elasticidade e a rigidez com valor menor, sobretudo no caso das placas de $10 \mathrm{~cm} \times 10 \mathrm{~cm}$.

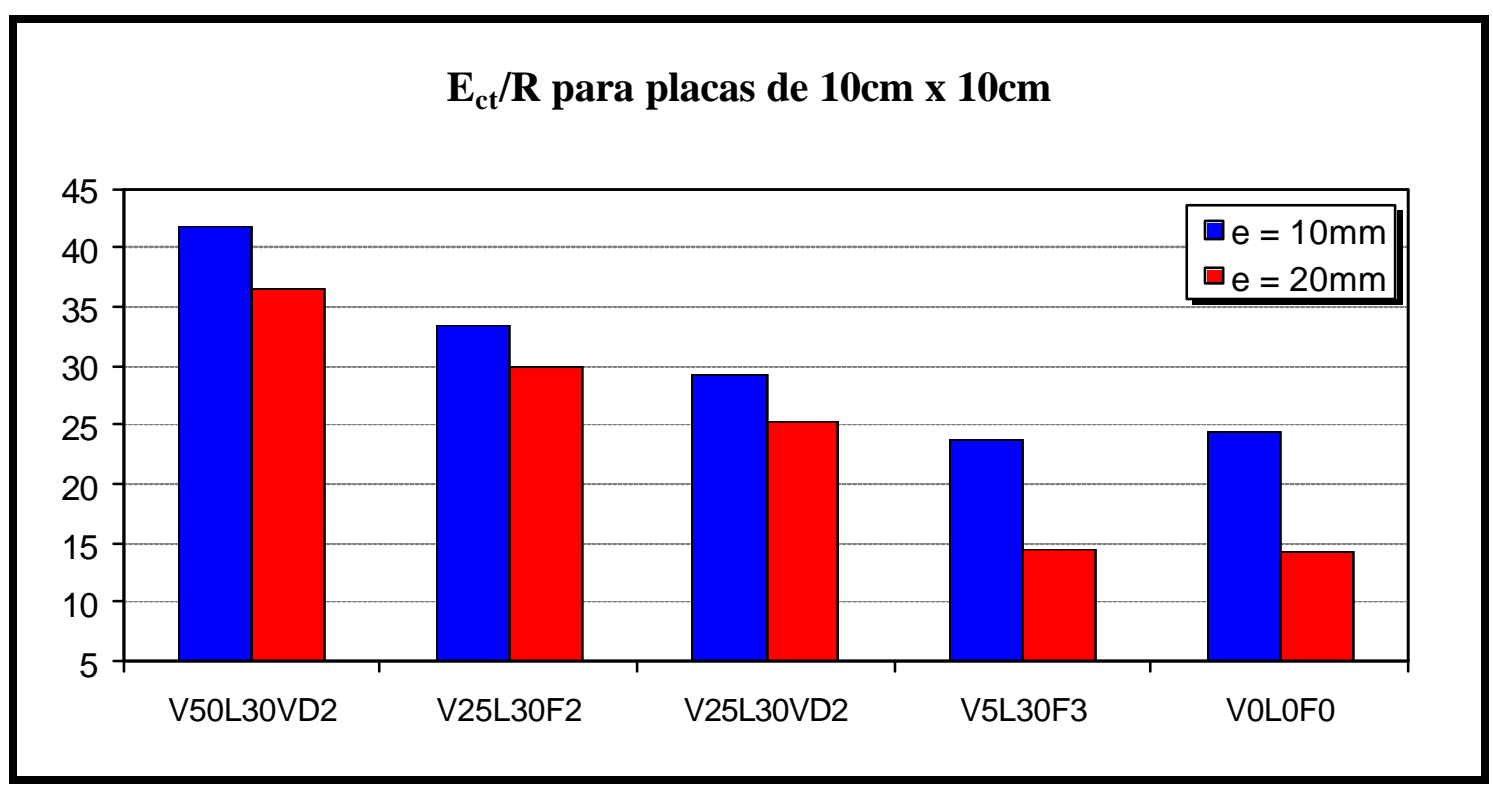

Figura $4.59-\mathrm{E}_{\mathrm{ct}} / \mathrm{R}$ para as placas de $10 \mathrm{~cm} \times 10 \mathrm{~cm}$

Nas Figuras 4.58 e 4.59 pôde-se observar os valores da razão entre a elasticidade e a rigidez para cada traço e espessuras estudados. A partir de todos aqueles valores, calcularam-se os valores médios das relações entre o módulo de elasticidade e a rigidez (E/R) para cada espessura (5, 10 e $20 \mathrm{~mm})$, tanto para elasticidade tangente como para secante, como se pode observar na Tabela 4.18.

Tabela 4.18 - Razão média entre o módulo de elasticidade e a rigidez (E/R)

\begin{tabular}{||c|c|c|c|c|c||}
\hline \multirow{2}{*}{ E/R } & \multicolumn{2}{|c|}{ Placa de 10cm $\times \mathbf{1 0 c m}$} & \multicolumn{3}{|c||}{ Placa de $\mathbf{1 5 c m} \times \mathbf{1 5 c m}$} \\
\cline { 2 - 6 } & $\mathbf{1 0} \mathbf{m m}$ & $\mathbf{2 0 m m}$ & $\mathbf{5 m m}$ & $\mathbf{1 0 m m}$ & $\mathbf{2 0 m m}$ \\
\hline tangente & 27,7 & 25,1 & 59,1 & 35,9 & 21,6 \\
\hline secante & 25,2 & 23,8 & 51,7 & 31,7 & 19,1 \\
\hline
\end{tabular}


Pela Tabela 4.18 nota-se que o valor do módulo de elasticidade é da ordem de $\mathbf{2 3}$ a 28 vezes o valor da rigidez da placa quando se utiliza almofada de $10 \mathrm{~cm} \times 10 \mathrm{~cm}$. No caso de se utilizar almofada de maior área $(15 \mathrm{~cm} \times 15 \mathrm{~cm})$, o valor da razão E/R tem maior variação com a espessura, sendo que para almofadas de $5 \mathrm{~mm}$ de espessura o módulo de elasticidade tem seu valor da ordem de 50 a 60 vezes o valor da rigidez, 30 a 35 vezes para almofadas de $10 \mathrm{~mm}$ e 20 vezes para almofadas de $20 \mathrm{~mm}$.

Outra correlação realizada diz respeito à razão entre a resistência à compressão $\left(f_{c}\right)$ e a rigidez $(R)$. Os resultados dessa correlação para placas de $15 \mathrm{~cm}$ x $15 \mathrm{~cm}$ e placas de $10 \mathrm{~cm}$ x $10 \mathrm{~cm}$ podem ser observados nas Figuras 4.60 e 4.61, respectivamente.

Ao se observar a Figura 4.60 (placas de $15 \mathrm{~cm}$ x $15 \mathrm{~cm}$ ) nota-se que quanto menor a espessura maior o valor da relação €/R., sendo que a resistência à compressão vale entre $12 \%$ e $20 \%$ da rigidez para placas de espessura $5 \mathrm{~mm}$, entre $8 \%$ e $12 \%$ da rigidez para placas de espessura $10 \mathrm{~mm}$ e entre $4 \%$ e $8 \%$ da rigidez para placas de $20 \mathrm{~mm}$.

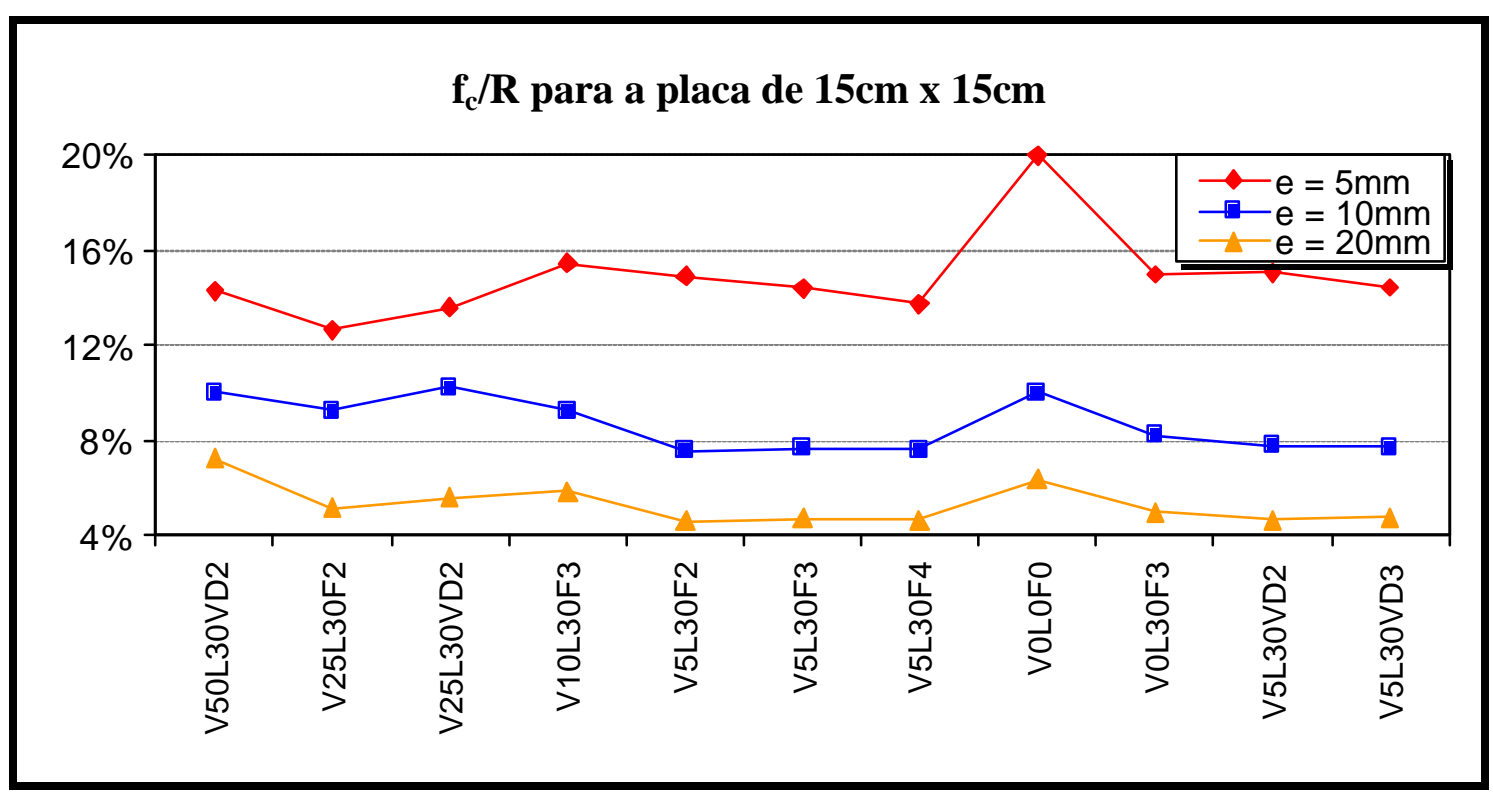

Figura 4.60 $-f_{c} / R$ para as placas de $15 \mathrm{~cm} \times 15 \mathrm{~cm}$

$\mathrm{Na}$ Figura 4.60 também se pode notar que a razão $\mathrm{f}_{\mathrm{c}} / \mathrm{R}$ atinge um pico de, aproximadamente, $20 \%$ para argamassa simples (V0L0F0) e espessura $5 \mathrm{~mm}$, sendo que para os demais traços e $5 \mathrm{~mm}$ de espessura a razão fica entre $12 \%$ e $15 \%$. Quando se trata de placas de $10 \mathrm{~mm}$ de espessura, nota-se que as almofadas moldadas com maior quantidade de vermiculita $(25 \%$ ou $50 \%)$ e as de argamassa simples apresentam a 
relação com valor em torno de $10 \%$, ao passo que as almofadas com pouca vermiculita ou sem elas mas com fibra e látex apresentam a relação com valor um pouco menor, em torno de $8 \%$.

Como se espera alta resistência com baixo valor de rigidez, conclui-se que os melhores traços para se utilizarem são aqueles que possuem maior relação entre $f_{\mathrm{c}} \mathrm{e} \mathrm{R}$. Nota-se, portanto, que as melhores misturas a se utilizarem são aquelas que possuem de $5 \%$ a $10 \%$ de vermiculita.

Ao se observar a Figura 4.61 (placas de $10 \mathrm{~cm}$ x $10 \mathrm{~cm}$ ) nota-se que quanto maior a espessura menor o valor da relação $\mathrm{f}_{\mathrm{c}} / \mathrm{R}$, sendo que a resistência à compressão vale entre $2 \%$ e $6 \%$ da rigidez para placas de espessura $20 \mathrm{~mm}$ e entre $5 \%$ e $7 \%$ da rigidez para placas de espessura $10 \mathrm{~mm}$. Na Figura 4.61 também se pode notar que a razão f̊f $\mathrm{R}$ atinge um pico de, aproximadamente, 7\% para V25L30VD2 e espessura 10mm, sendo que a argamassa simples (traço de referência) possui uma razão próxima de 5\%. Notase, portanto, que ao se acrescentar fibras, látex estireno-butadieno e vermiculita à argamassa obtém-se um maior valor para a razão entre a resistência à compressão e a rigidez, contanto que a quantidade de vermiculita fique entre $5 \%$ e $25 \%$, já que quando se utiliza o material na taxa de 50\% em massa, obtém-se um valor para a razão bastante próximo daquele obtido para o traço de referência.

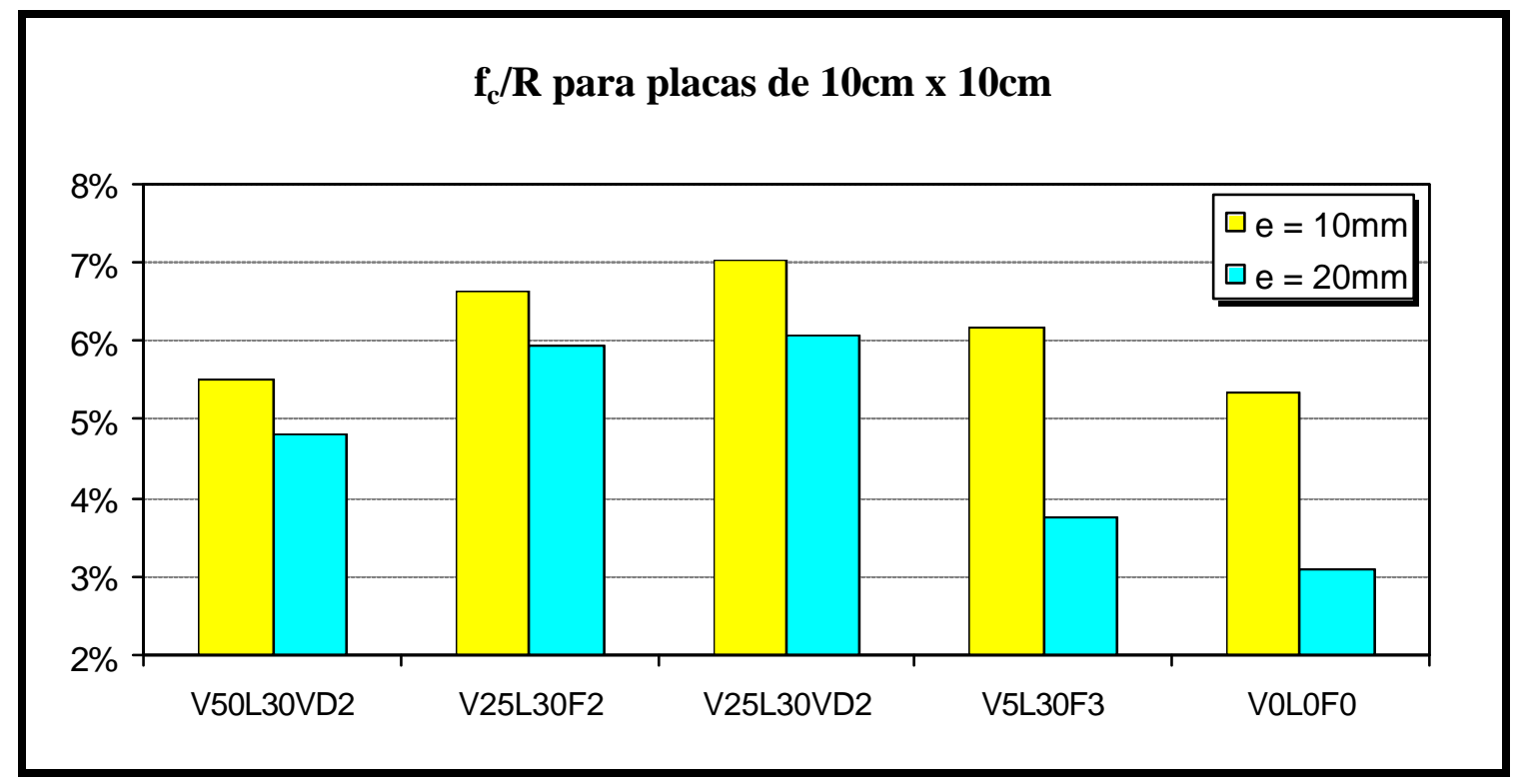

Figura 4.61 $-\mathrm{f}_{\mathrm{c}} / \mathrm{R}$ para as placas de $10 \mathrm{~cm} \times 10 \mathrm{~cm}$ 
Para conclusão das comparações apresentam-se na Tabela 4.19 os valores médios das razões $\mathrm{f}_{\mathrm{c}} / \mathrm{R}$ (resistência à compressão e rigidez) e $\mathrm{R} / \mathrm{f}_{\mathrm{c}}$ (rigidez e resistência à compressão) para cada espessura e dimensão da almofada.

Tabela $4.19-f_{c} / R$ e $R / f_{c}$ para almofadas de $15 \mathrm{~cm}$ x $15 \mathrm{~cm}$ e de $10 \mathrm{~cm} \times 10 \mathrm{~cm}$

\begin{tabular}{||c|c|c|c|c|c||}
\hline \multirow{2}{*}{ Relação } & \multicolumn{2}{|c|}{ Placa de 10cm x 10cm } & \multicolumn{3}{|c||}{ Placa de 15cm x 15cm } \\
\cline { 2 - 6 } & $\mathbf{1 0 m m}$ & $\mathbf{2 0} \mathbf{m m}$ & $\mathbf{5 m m}$ & $\mathbf{1 0 m m}$ & $\mathbf{2 0} \mathbf{m m}$ \\
\hline $\mathrm{f}_{\mathrm{c}} / \mathrm{R}$ & $6,1 \%$ & $4,8 \%$ & $14,5 \%$ & $8,2 \%$ & $5,0 \%$ \\
\hline $\mathrm{R} / \mathrm{f}_{\mathrm{c}}$ & 16,4 & 20,6 & 6,9 & 12,1 & 19,9 \\
\hline
\end{tabular}

Observa-se pela Tabela 4.19 que a relação entre a rigidez e a resistência à compressão é maior quando se utiliza almofadas de menor dimensão $(10 \mathrm{~cm} \times 10 \mathrm{~cm}) \mathrm{e}$ que essa mesma relação é crescente conforme se aumenta a espessura.

Nota-se, de forma geral, que a rigidez assume um valor de 15 a 20 vezes o valor da resistência à compressão quando se utilizam almofadas de $10 \mathrm{~cm} \times 10 \mathrm{~cm}$; todavia, quando se utilizam almofadas maiores $(15 \mathrm{~cm} \times 15 \mathrm{~cm})$ o valor da razão $R / \mathrm{F}_{\mathrm{c}}$ varia mais com a espessura, sendo de, aproximadamente, 7 vezes para espessura $5 \mathrm{~mm}, 12$ vezes para espessura $10 \mathrm{~mm}$ e $\mathbf{2 0}$ vezes para espessura $20 \mathrm{~mm}$. 


\subsection{Ensaios de ligações de blocos}

Para realização da análise dos resultados obtidos nos ensaios de ligações, optou-se por apresentar os valores absolutos em média e os valores em porcentagem dos ensaios tipos 2 e 3 com relação aos valores dos ensaios tipo 1 (corpos sem emenda). Destaca-se que os valores das resistências à compressão dos blocos sem emenda ficaram, em média, numa faixa entre $35 \mathrm{MPa}$ e $40 \mathrm{MPa}$. Para os casos em que se utilizavam os valores em porcentagem, pegava-se o valor da resistência do protótipo sem emenda com valor unitário e verificavam-se os valores das resistências dos outros protótipos (levando em consideração emenda e inclinação) em relação a este valor a partir de regras de três. Portanto, a média dos valores dos protótipos sem emenda valerá $100 \%$ e os demais protótipos possuirão um valor percentual relacionado a este.

Nas Tabelas 4.20, 4.21, 4.22, 4.23 e 4.24 apresentam-se os valores médios das tensões medidas a partir dos ensaios para cada uma das 5 séries efetuadas nos três traços especificados (V5L30F3, V25L30VD2 e V50L30VD2).

Tabela 4.20 - Tensão média em MPa para série $1(\mathrm{i}=0 \%$ e e $=10 \mathrm{~mm})$

\begin{tabular}{||c|c|c|c||}
\hline Traço & Sem emenda & $\begin{array}{c}\text { Com emenda e sem } \\
\text { almofada }\end{array}$ & $\begin{array}{c}\text { Com emenda e com } \\
\text { almofada }\end{array}$ \\
\hline V5L30F3 & \multirow{3}{*}{37,26} & 26,98 & 35,20 \\
\cline { 1 - 1 } V25L30VD2 & & & 30,91 \\
\hline V50L30VD2 & & & 27,80 \\
\hline
\end{tabular}

Ao se observar as 5 tabelas (4.20 a 4.24) pode-se notar que apenas para a série 3 (i $=10 \% \mathrm{e} \mathrm{e}=20 \mathrm{~mm}$ ) que o traço V25L30VD2 promove a maior resistência à compressão, ao passo que para todas as outras séries o traço que promove a maior resistência à compressão é o V5L30F3.

Nota-se, também, que ao se utilizar inclinação, ligação excêntrica, a resistência à compressão do conjunto assume valor bastante inferior se comparada aos conjuntos com ligação sem inclinação (não excêntrica). Também se nota que em todos os casos, o conjunto sem emenda apresenta maior resistência, em razão da monoliticidade. 
Tabela 4.21 - Tensão média em MPa para série $2(i=10 \%$ e e $=10 \mathrm{~mm})$

\begin{tabular}{|c|c|c|c||}
\hline Traço & Sem emenda & $\begin{array}{c}\text { Com emenda e sem } \\
\text { almofada }\end{array}$ & $\begin{array}{c}\text { Com emenda e com } \\
\text { almofada }\end{array}$ \\
\hline V5L30F3 & \multirow{2}{*}{38,76} & 5,89 & 9,33 \\
\cline { 1 - 2 } V25L30VD2 & & & 7,61 \\
\cline { 1 - 1 } V50L30VD2 & & & 6,17 \\
\hline
\end{tabular}

Tabela 4.22 - Tensão média em MPa para série $3(\mathrm{i}=10 \%$ e e $=20 \mathrm{~mm})$

\begin{tabular}{|c|c|c|c||}
\hline Traço & Sem emenda & $\begin{array}{c}\text { Com emenda e sem } \\
\text { almofada }\end{array}$ & $\begin{array}{c}\text { Com emenda e com } \\
\text { almofada }\end{array}$ \\
\hline V5L30F3 & & & 9,54 \\
\cline { 1 - 2 } V25L30VD2 & 36,97 & 5,32 & 11,79 \\
\cline { 1 - 2 } V50L30VD2 & & & 7,35 \\
\hline
\end{tabular}

Comparando-se as séries 2 e 3 (Tabelas 4.21 e 4.22), nas quais se utiliza inclinação de $10 \%$, nota-se que ao se utilizar almofadas de maior espessura $(20 \mathrm{~mm})$ obtém-se conjuntos com maior resistência à compressão. No $2^{\circ}$ caso, série 3 , o traço que atribui maior resistência é aquele com 25\% de vermiculita (V25L30VD2), ao passo que para a série 2 é o V5L30F3. No entanto, cabe destacar que estes ensaios com aplicação de carga excêntrica (todas as séries que apresentam inclinação nas ligações: séries 2, 3 e 5) não apresentaram resultados muito consistentes e conclui-se que o ensaio deveria ser realizado de outra forma para se avaliar de maneira mais completa o comportamento do compósito com relação a cargas excêntricas; sendo que da forma como foi realizado conclui-se apenas que a introdução de almofadas do compósito nas ligações atribui maior resistência ao conjunto com ligações inclinadas. No caso desta dissertação, torna-se mais conveniente avaliar os resultados das séries em que as ligações não possuem inclinação (séries 1 e 4).

Sendo assim, ao se comparar as séries 1 e 4 (Tabelas 4.20 e 4.23), nas quais as ligações entre os blocos não possuem inclinação, nota-se que, para ambas, o traço que atribui maior resistência ao conjunto é o V5L30F3. Comparando os valores das resistências, nota-se que os resultados são bastante próximos; entretanto ao comparar esses resultados aos dos corpos com emenda e sem almofada, nota-se que ao se utilizar almofadas há um acréscimo de resistência da ordem de $30 \%$ para almofada de $10 \mathrm{~mm}$ e 
um acréscimo da ordem de $44 \%$ para almofada de espessura $20 \mathrm{~mm}$, o que mostra que há um maior acréscimo de resistência no conjunto ao se utilizar almofada de espessura $20 \mathrm{~mm}$ e traço V5L30F3.

Tabela 4.23 - Tensão média em MPa para série 4 (i = 0\% e e = 20mm)

\begin{tabular}{|c|c|c|c||}
\hline Traço & Sem emenda & $\begin{array}{c}\text { Com emenda e sem } \\
\text { almofada }\end{array}$ & $\begin{array}{c}\text { Com emenda e com } \\
\text { almofada }\end{array}$ \\
\hline V5L30F3 & \multirow{2}{*}{37,88} & 24,93 & 35,82 \\
\cline { 1 - 2 } V25L30VD2 & & & 28,96 \\
\cline { 1 - 2 } \cline { 4 - 4 } V50L30VD2 & & & 21,92 \\
\hline
\end{tabular}

Tabela 4.24 - Tensão média em MPa para série 5 (i = 5\% e e $=10 \mathrm{~mm})$

\begin{tabular}{|c|c|c|c||}
\hline Traço & Sem emenda & $\begin{array}{c}\text { Com emenda e sem } \\
\text { almofada }\end{array}$ & $\begin{array}{c}\text { Com emenda e com } \\
\text { almofada }\end{array}$ \\
\cline { 1 - 2 } V5L30F3 & & & 14,79 \\
\cline { 1 - 2 } V25L30VD2 & 37,07 & 7,97 & 12,89 \\
\cline { 1 - 2 } V50L30VD2 & & & 10,76 \\
\hline
\end{tabular}

Com relação à série 5 (Tabela 4.24) destaca-se apenas que o traço que atribui maior resistência ao conjunto é novamente o V5L30F3 e que suas resistências são superiores às dos conjuntos com 10\% de inclinação.

Na seqüência, são apresentadas 5 figuras (4.62 a 4.66) nas quais se apresentam as tensões em porcentagem de cada uma das 5 séries estudadas, para melhor observação dos resultados anteriormente mostrados e discutidos.

Na Figura 4.62 podem ser observados os resultados da $1^{a}$ série de ensaios para cada um dos traços especificados no capítulo de descrição dos ensaios de ligações de blocos. Portanto, serão mostrados os resultados dos corpos sem inclinação e com almofada de $1 \mathrm{~cm}$ de espessura. Apenas no caso de se utilizar o traço com $50 \%$ de vermiculita é que praticamente não houve acréscimo de resistência no conjunto. 


\section{Ligações (i=0\% e e=10mm)}

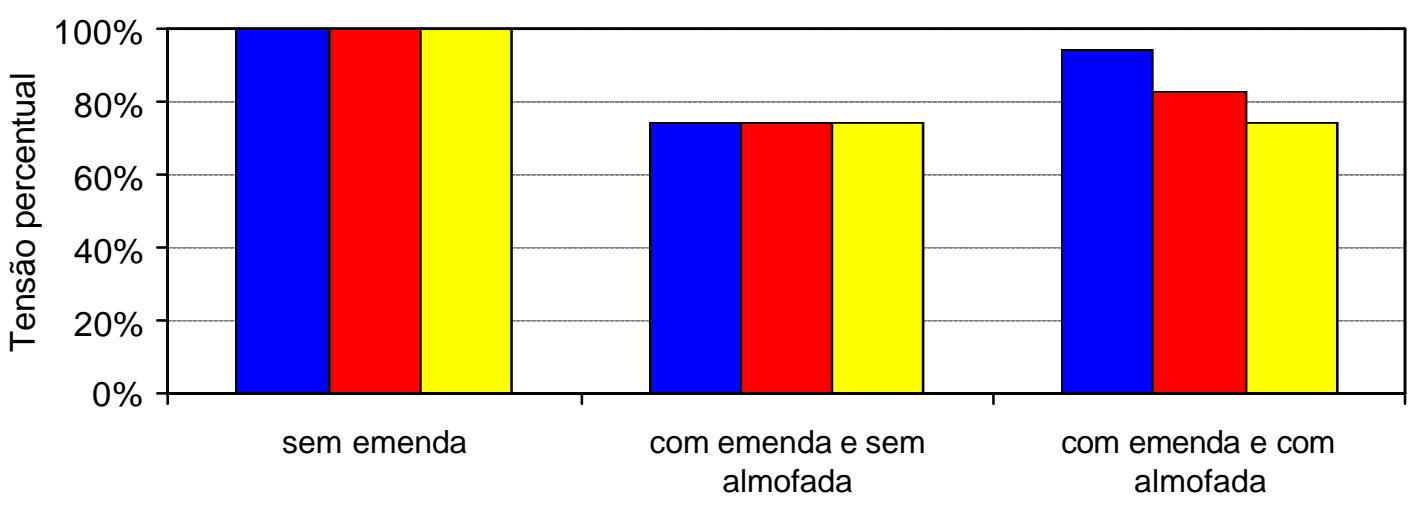

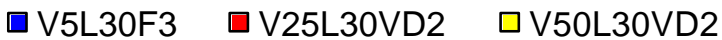

Figura 4.62 - Relação entre as tensões (i = 0\% e e = 10mm) - Série 1

Na Figura 4.63, podem ser avaliados os resultados da $2^{\mathrm{a}}$ série de ensaios para cada um dos traços. Nesta figura, observa-se que quando se tem emenda e uma certa inclinação na ligação (excêntrica), como é o caso da figura em questão, pode-se utilizar almofada do compósito para que a resistência do conjunto aumente um pouco seu valor. Neste caso específico, utilizou-se almofada de $10 \mathrm{~mm}$ de espessura e uma inclinação de $10 \%$ em cada um dos corpos que compõem a ligação e percebeu-se acréscimo de resistência para os três traços especificados.

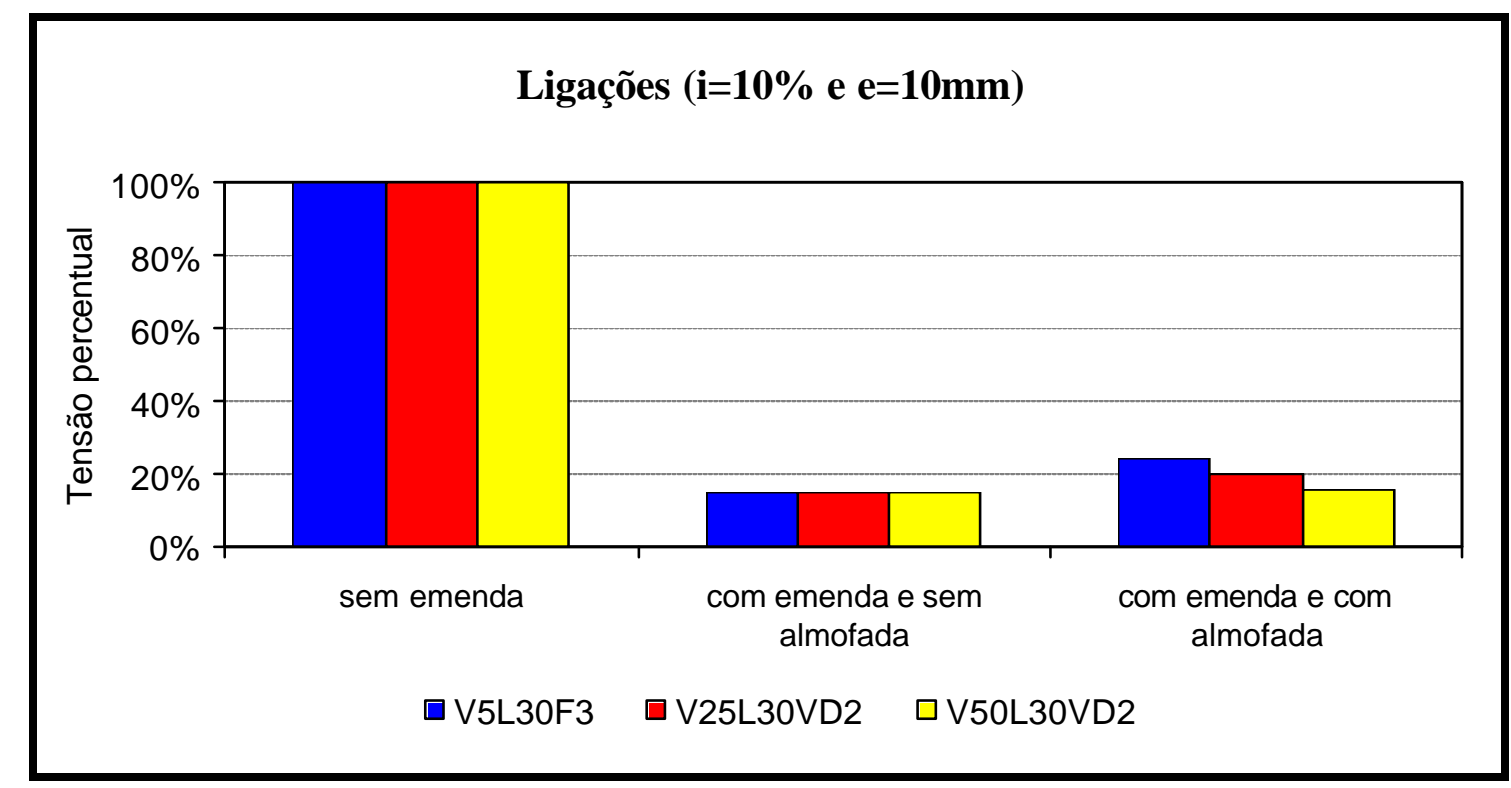

Figura 4.63 - Relação entre as tensões $(i=10 \%$ e e $=10 \mathrm{~mm})$ - Série 2 
Na Figura 4.64, podem ser avaliados os resultados da $3^{\text {a }}$ série de ensaios para cada um dos traços. Dessa forma, serão mostrados os resultados dos corpos com $10 \%$ de inclinação e com almofada de $20 \mathrm{~mm}$ de espessura. Neste caso, propõe-se a mesma inclinação da série 2, entretanto fundem-se no conjunto almofadas com o dobro da espessura anteriormente mencionada, portanto $20 \mathrm{~mm}$ e, também neste caso, nota-se que a resistência do conjunto à compressão aumenta um pouco seu valor para os três traços em que as almofadas foram moldadas, todavia, como dito anteriormente, a avaliação dos casos em que há excentricidade (inclinação nas ligações) deveria ser realizada por outro tipo de ensaio.

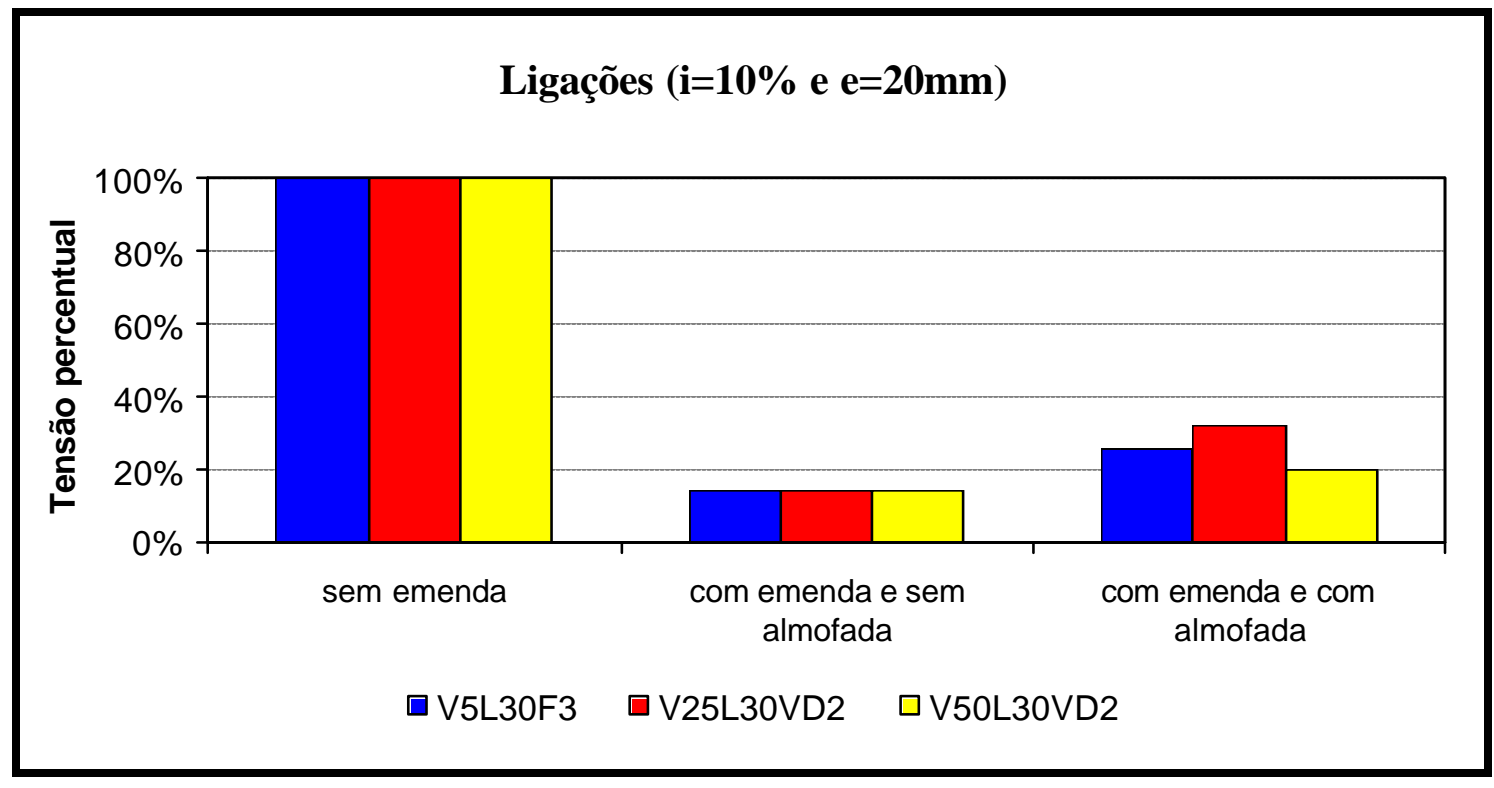

Figura 4.64 - Relação entre as tensões $(i=10 \%$ e e $=20 \mathrm{~mm})$ - Série 3

Na Figura 4.65, podem ser avaliados os resultados das tensões percentuais da $4^{\mathrm{a}}$ série de ensaios para cada um dos traços. Dessa forma, serão mostrados os resultados dos corpos sem inclinação e com almofada de $20 \mathrm{~mm}$ de espessura.

Neste caso específico, percebeutse que não houve acréscimo de resistência devido à presença da almofada apenas no último traço (V50L30VD2), pois ao se utilizar, na soma das almofadas, $40 \mathrm{~mm}$ de almofada do compósito junto de $160 \mathrm{~mm}$ de concreto do conjunto, a resistência do conjunto diminui bastante quando se tem grande quantidade de vermiculita presente na mistura. 


\section{Ligações (i=0\% e e=20mm)}

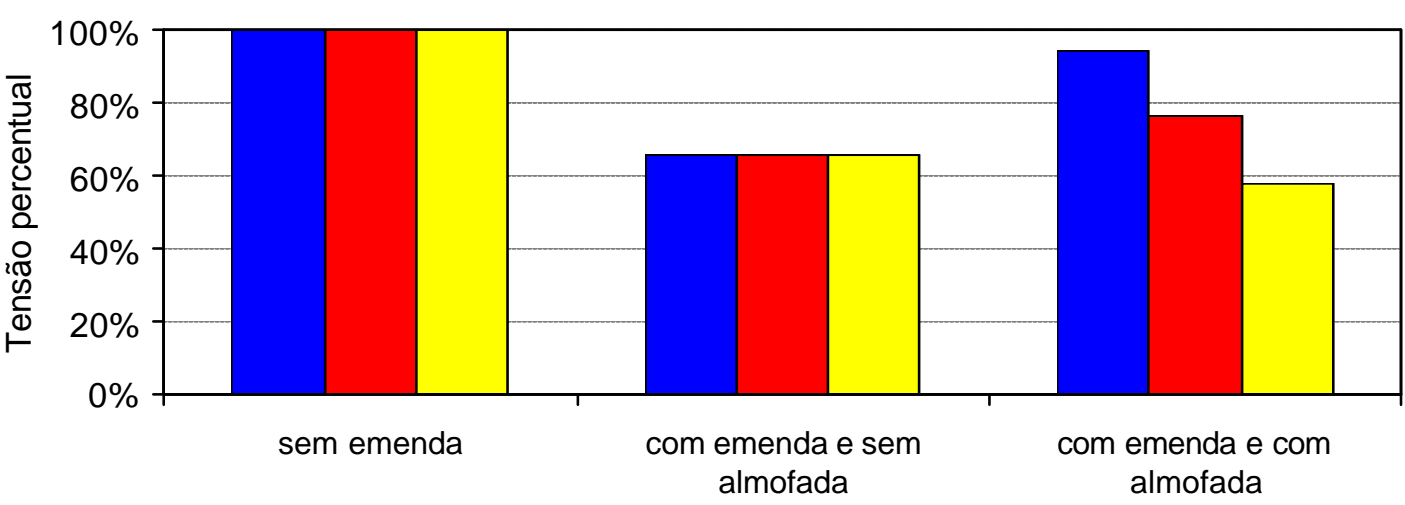

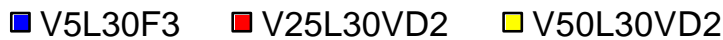

Figura 4.65 - Relação entre as tensões (i = 0\% e e = 20mm) - Série 4

\section{Ligações (i=5\% e e=10mm)}

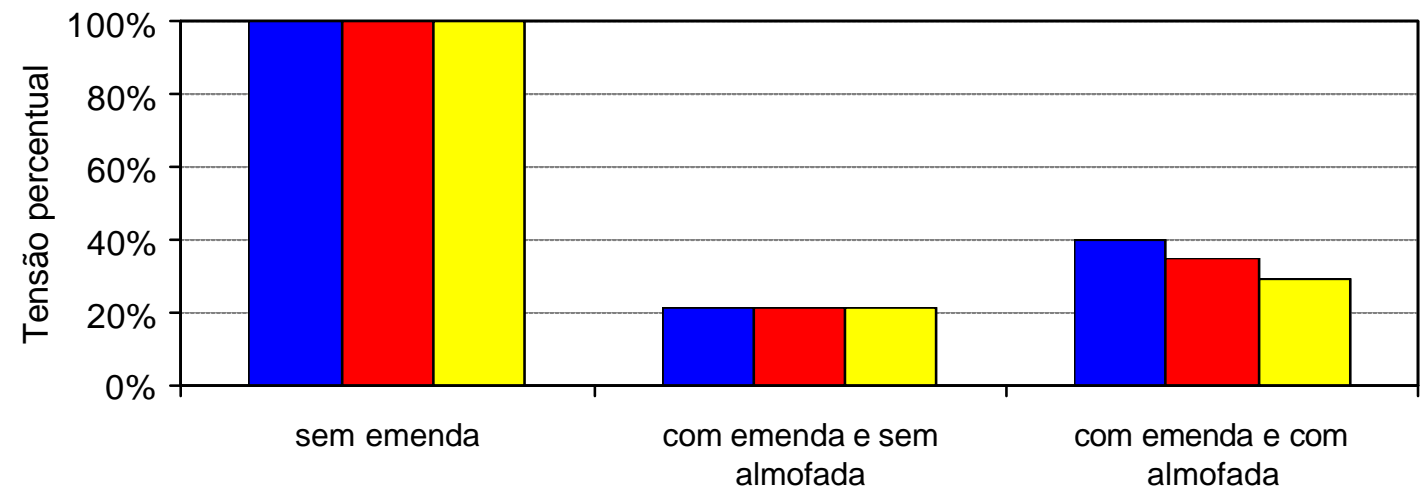

$\square$ V5L30F3 $\square$ V25L30VD2 $\square$ V50L30VD2

Figura 4.66 - Relação entre as tensões $(i=5 \%$ e e $=10 \mathrm{~mm})$ - Série 5

Na Figura 4.66 observa-se que quando se tem emenda e uma inclinação um pouco menor (5\%) na ligação (excêntrica), como é o caso da figura em questão, também se pode utilizar almofada do compósito para que a resistência do conjunto aumente seu valor. Neste caso específico, utilizourse almofada de $10 \mathrm{~mm}$ de espessura e uma inclinação de $5 \%$ em cada um dos corpos que compõem a ligação e percebeu-se acréscimo de resistência para os três traços especificados.

Observados os resultados de todas as séries e estabelecidas as análises referentes à 
presença ou não das almofadas pode-se concluir que para todos os casos a presença da almofada de apoio (compósito) atribui acréscimo na resistência à compressão dos blocos estudados.

Fazendo uma análise geral, notourse que à medida que se inclinava uma das seções dos corpos-de-prova perdia-se em resistência, haja vista a aplicação de carga excêntrica que ocorre nestes casos. No caso de se utilizar ligações sem inclinação verificou-se que os valores das tensões ficavam muito próximos da tensão máxima obtida ao se utilizar corpos sem emenda, sobretudo quando se utilizava almofada de 20mm de espessura moldadas no traço V5L30F3.

Na sequiência, são apresentadas algumas figuras das séries que utilizam almofada de $1 \mathrm{~cm}$ de espessura, para melhor visualização da importância da presença do compósito nas emendas para o acréscimo de resistência.

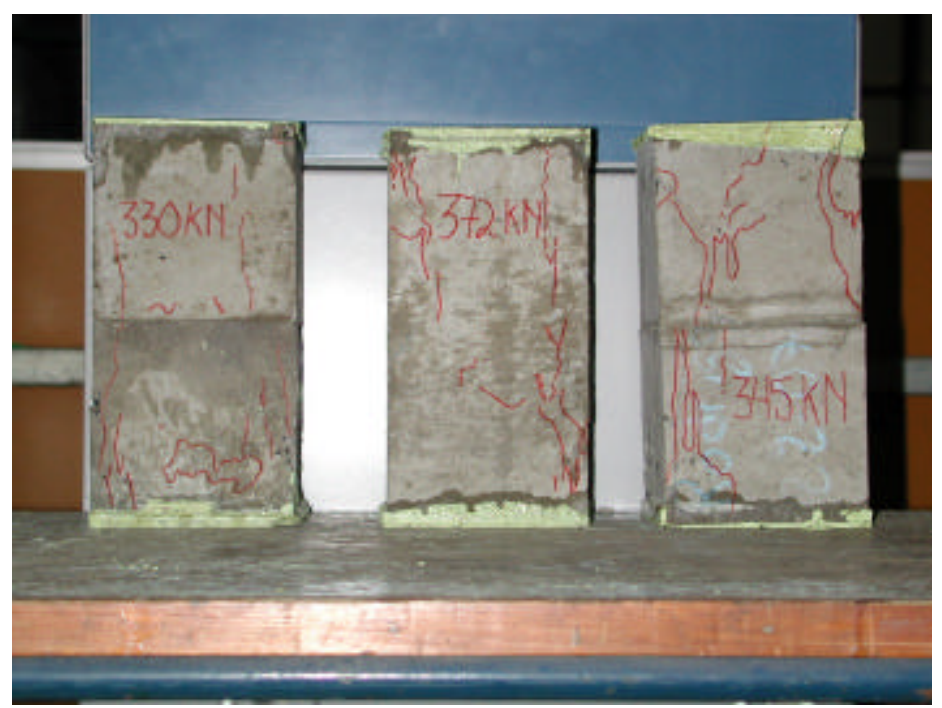

Figura 4.67 -Carga máxima aplicada $(i=0 \%$ e e $=10 \mathrm{~mm})-$ V5L30F3

Analisando-se a Figura 4.67 (almofadas de traço V5L30F3) pode-se notar claramente a influência da almofada na emenda. Nota-se que, nos corpos acoplados em que se utiliza a almofada, a distribuição de tensões é maior e as fissuras no corpo inferior, que simboliza o pilar, são menores e aparecem em menor número; somado ao fato de que quando se utiliza almofada na emenda, o conjunto se rompe com uma carga maior.

Na Figura 4.69 (V25L30VD2) ocorre praticamente o mesmo que fora descrito 
para a Figura 4.67, entretanto resistindo a cargas menores, sobretudo em razão da maior inclinação existente neste caso, somado ao fato de que não apareceram fissuras no corpo inferior e as fissuras no corpo superior foram menores em dimensão e em número se comparadas às da Figura 4.70 (V5L30F3), a qual representa corpos com seção inclinada de $10 \%$ cada, somando $20 \%$ de inclinação. Isso demonstra a eficiência da almofada de $10 \mathrm{~mm}$ de espessura aplicada na extremidade dos corpos inclinados de $5 \%$ e compondo a emenda, somando $10 \%$ de inclinação.

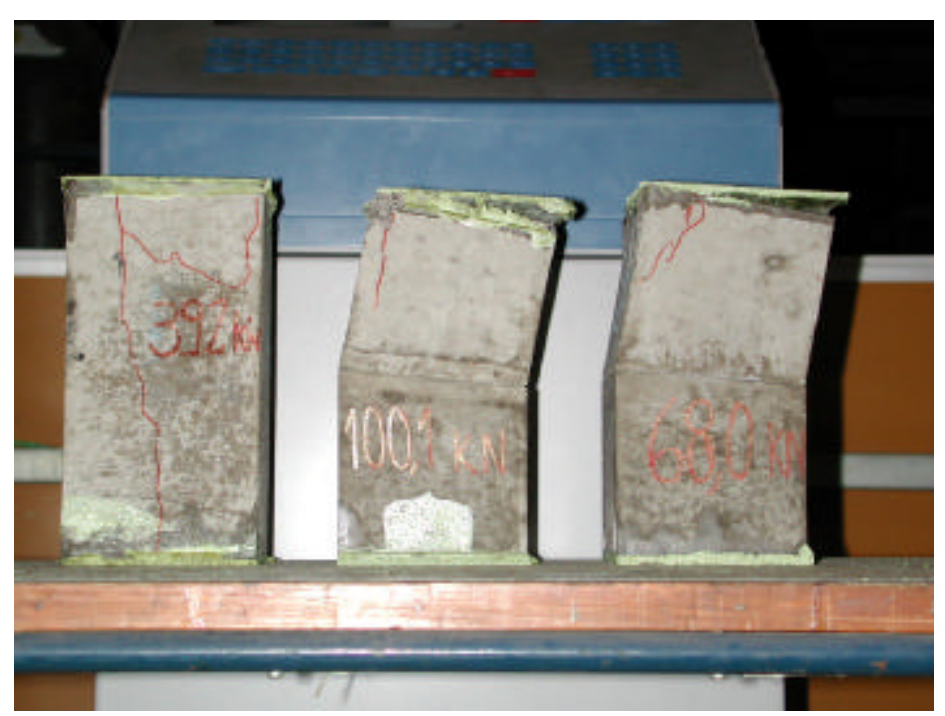

Figura 4.68 -Carga máxima aplicada $(\mathrm{i}=10 \%$ e e $=10 \mathrm{~mm})-$ V5L30F3

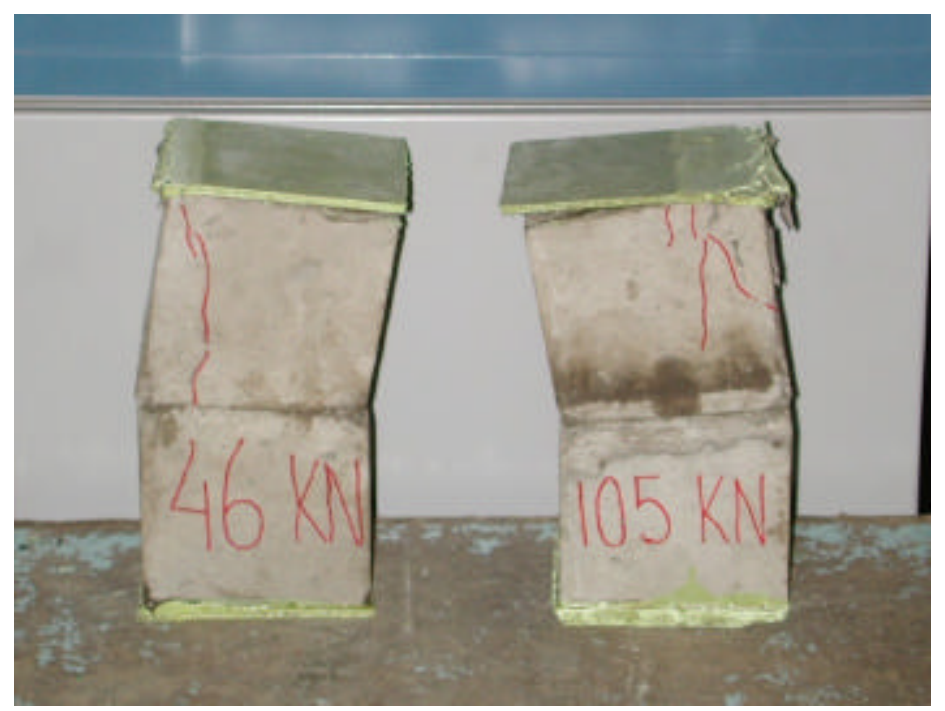

Figura 4.69 -Carga máxima aplicada $(i=10 \%$ e e $=10 \mathrm{~mm})-$ V25L30VD2

As Figuras 4.68 e 4.69 representam a série 2 e, como dito anteriormente, quanto 
menor a quantidade de vermiculita empregada no compósito, maior será o acréscimo em porcentagem de resistência do protótipo com almofada de espessura 10mm e inclinação $10 \%$.

Analisando-se de forma sucinta a Figura 4.70 (V5L30F3) pode-se visualizar claramente a influência da almofada na emenda, fato comprovado pelo corpo que está na extremidade direita, pois naquele caso nota-se que a almofada absorveu com grande eficiência a carga aplicada, impedindo que as fissuras atingissem o corpo inferior apesar da grande lasca que apareceu no corpo superior.

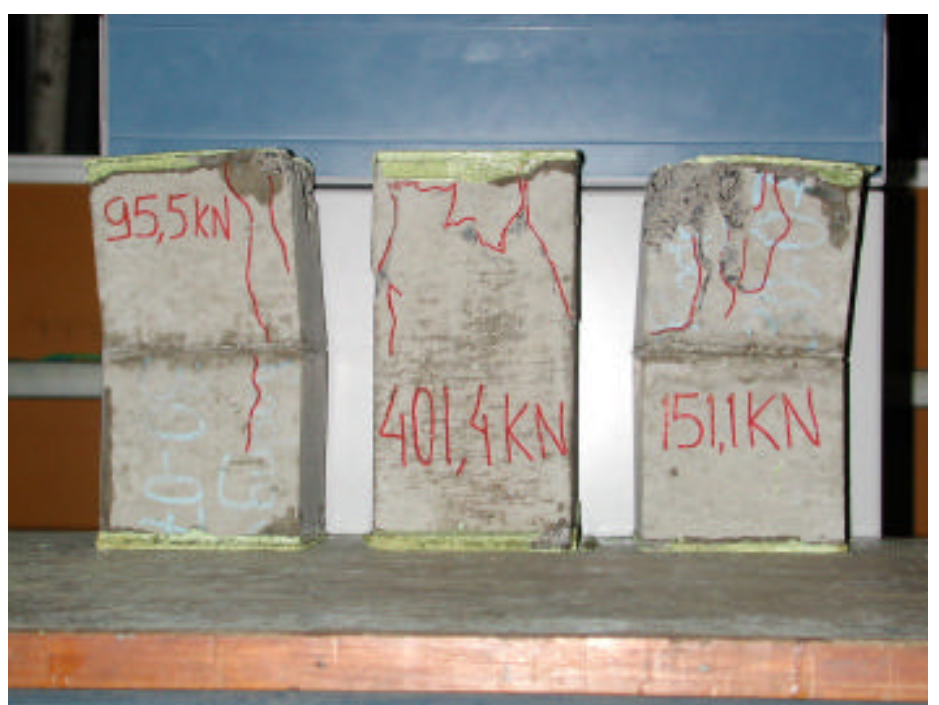

Figura 4.70 -Carga máxima aplicada $(\mathrm{i}=5 \%$ e e $=10 \mathrm{~mm})-$ V5L30F3

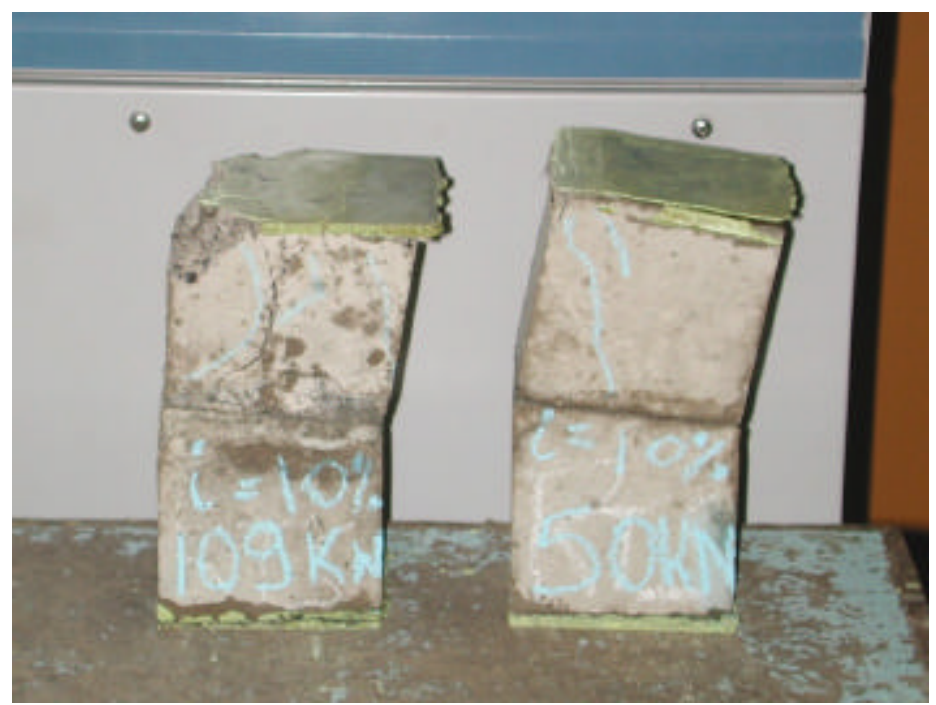

Figura 4.71-Carga máxima aplicada $(i=5 \%$ e e $=10 \mathrm{~mm})-$ V25L30VD2 
A influência positiva da almofada de apoio é ainda melhor notada no caso de se utilizar almofadas com maior quantidade de vermiculita, como pode ser visto na Figura $4.71(\mathrm{~V} 25 \mathrm{~L} 30 \mathrm{VD} 2)$.

Nota-se que, nos corpos acoplados em que se utiliza a almofada (Figura 4.71), a distribuição de tensões é maior e as fissuras no corpo inferior, que simboliza o pilar sobre o qual supostamente ocorre o giro da viga, são menores e aparecem em menor número; somado ao fato de que quando se utiliza almofada na emenda, o conjunto se rompe com uma carga maior.

\subsection{Análise de custo}

$\mathrm{Na}$ Tabela 4.25 pode-se observar o custo médio de uma almofada do compósito e também o custo de uma almofada de neoprene.

Tabela 4.25 - Análise de custo das almofadas (em R\$)

\begin{tabular}{||c|c|c|c|c|c||}
\hline \hline \multicolumn{2}{||c|}{ Almofada de 15cm x 15cm } & V5L30F3 & V25L30VD2 & V50L30VD2 & V0L0F0 \\
\hline \multirow{2}{*}{ e = 1cm } & Compósito & 0,88 & 0,82 & 0,73 & 0,14 \\
\cline { 2 - 7 } & Neoprene & \multicolumn{5}{|c||}{11,25} \\
\hline \multirow{2}{*}{ e = 2cm } & Compósito & 1,75 & 1,64 & 1,46 & 0,27 \\
\cline { 2 - 7 } & Neoprene & \multicolumn{5}{|c||}{22,50} \\
\hline
\end{tabular}

Pela Tabela 4.25 , nota-se que o custo da almofada é da ordem de $7 \%$ a $8 \%$ do custo da almofada de neoprene. A partir de pesquisa de campo com construtores que empregam elementos pré-moldados e almofada de neoprene nas ligações entre os elementos chegoutse a conclusão de que o emprego de almofadas de neoprene nas ligações corresponde a algo em torno de $2 \%$ do custo total da obra.

Para se ter uma melhor idéia, pode-se avaliar uma obra com custo total de $\mathrm{R} \$ 200.000,00$, utilizando elementos pré-fabricados e almofada de neoprene. O custo total das almofadas de neoprene a serem utilizadas seria de aproximadamente $\mathrm{R} \$ 4.000,00$, ao passo que se fossem utilizadas almofadas do compósito nas ligações seria gasto algo em torno de $\mathrm{R} \$ 300,00$, o que corresponderia a um custo praticamente insignificante no montante da obra, demonstrando ser a almofada do compósito uma boa opção com relação ao custo. 


\section{CONSIDERAÇÕES FINAIS E CONCLUSÕES}

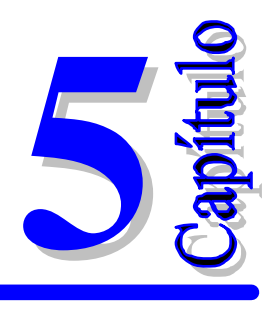

O compósito em questão apresentou boa capacidade de deformação, nos testes realizados, característica essa bastante importante para um material que deve ser utilizado em ligações de elementos pré-moldados.

Com base nos resultados obtidos a partir dos ensaios, promoveu-se uma análise crítica e avaliou-se o grau de eficiência do novo material para aplicação deste como almofada de apoio entre elementos pré-moldados de concreto. Concluiu-se, portanto, que o compósito é bastante eficiente para ser utilizado dessa forma, contanto que se verifique, entre outras coisas, o traço mais adequado para tal aplicação.

Ao se avaliar as características do material (compósito) por meio de ensaios de compressão, tração por compressão diametral e módulo de elasticidade, observou-se que as características de resistência e elasticidade variam bastante de traço a traço.

Em geral, a adição de vermiculita, látex estireno-butadieno e fibras à argamassa de cimento tende a reduzir o módulo de elasticidade do material, característica essa de grande importância para um material que deve ser utilizado como de enchimento.

Com relação a vermiculita, notoutse que as almofadas que possuíam maior quantidade do material em massa eram mais moles. Entretanto, observou-se uma notória capacidade de retenção de água por parte deste material e, à medida que se aumentava a quantidade de vermiculita nos traços, mais era absorvida a água durante a mistura, reduzindo a trabalhabilidade e, nestes casos, era necessário utilizar aditivos. Além disso, notou-se que o acréscimo de vermiculita, em todos os casos, promovia queda nos valores de resistência, elasticidade e rigidez, bem como permitia maior afundamento das almofadas, pois tornava as almofadas mais macias. 
Optou-se por se utilizar três quantidades distintas do material nas almofadas, 5\%, $25 \%$ e 50\%, pois, dessa forma, poder-se-ia avaliar, em conjunto, a rigidez, o afundamento e as resistências mecânicas das placas e, enfim, aplicá-las às 5 séries de ligações de blocos.

Com relação ao látex, percebeu-se que o mesmo auxiliava no aumento da trabalhabilidade, já que o mesmo corresponde a uma emulsão na qual se encontram 50\% de água; entretanto maiores quantidades do produto motivaram queda de resistência em alguns traços, sobretudo nos casos em que se utilizava $40 \%$ do produto. Optourse, então, por se utilizar a emulsão em quantidades não superiores a 30\%, a partir da avaliação dos resultados de seu comportamento em conjunto com vermiculita e fibras adicionadas à argamassa.

As fibras de PVA e de vidro apresentaram bom desempenho na modificação de argamassas. O uso dessas fibras proporcionou um incremento nas propriedades mecânicas de resistência e rigidez do compósito. Contudo, o acréscimo dessas fibras deve ser controlado a fim de não comprometer a trabalhabilidade na moldagem e adensamento das almofadas.

Percebeu-se que uma quantidade mais adequada de fibra de PVA a se utilizar era a de $3 \%$, com relação à massa de cimento, quando se utilizavam pequenas quantidades de vermiculita (até $10 \%$ do produto em massa), pois não havia dificuldade na moldagem e a resistência do compósito possuía valores satisfatórios, sem a necessidade de acréscimo de aditivos durante a moldagem. No caso da fibra de vidro, mais densa, a melhor quantidade foi a de $2 \%$ em massa, sobretudo quando se tratavam de traços com maiores quantidades de vermiculita $(25 \%$ ou $50 \%)$. Já a fibra de polipropileno, menos densa que a de PVA, além de reduzir a trabalhabilidade, devido ao seu maior comprimento, atribuiu menores valores de resistência ao compósito.

Ficou clara a influência das fibras, sobretudo as de PVA e de vidro, no sentido de evitar grandes fissuras, lascas ou, até mesmo, a ruptura completa do corpo-de-prova quando o mesmo era submetido à tração ou à compressão. No caso em que os corposde-prova foram submetidos à tração, ficou ainda mais nítida a ação das fibras na interceptação das fissuras, principalmente quando se tratava de fibra de vidro.

Com relação à rigidez e ao afundamento das almofadas, em geral, notourse que o acréscimo de fibras promovia um aumento no valor da rigidez e também do 
afundamento das almofadas do compósito mediante aplicação de carga localizada; e o acréscimo de vermiculita, por sua vez, acarretava diminuição no valor dessa rigidez em contraposição ao aumento do afundamento, por tornar a almofada mais macia.

Verificou-se, também, que quanto maior a espessura maior era a rigidez da almofada, sobretudo no caso das almofadas com menor área da base. Acredita-se que isso ocorra em razão das imperfeições presentes nas bordas inferior e superior das placas. Essas imperfeições apresentam, aproximadamente, as mesmas dimensões para as três espessuras de placas, dessa forma, elas são percentualmente maiores quando se utilizam almofadas de menor espessura, influenciando nos valores das rigidezes das almofadas de menor espessura. Ao se avaliar o efeito de forma das placas, observou-se que as placas de menor área da base $(10 \mathrm{~cm} \times 10 \mathrm{~cm})$ possuíam maior rigidez, sobretudo para as placas de maior espessura.

Com relação ao afundamento, que corresponde à capacidade de acomodar imperfeições e é verificado mediante a aplicação de carga localizada, notourse que o mesmo apresentou concordância com a rigidez; neste caso, as almofadas de menor espessura, portanto menos rígidas, possuíam maior afundamento percentual em relação às demais, sendo que o maior afundamento ocorreu para traços com maior quantidade de vermiculita e fibras.

Notou-se que todos os traços que compunham as almofadas de $10 \mathrm{~cm} \times 10 \mathrm{~cm}$ apresentavam rigidez maior que as rigidezes das madeiras (Eucalipto Citriodora e Pinus Taeda) e que do cloropreno (neoprene). Em se comparando a almofada do compósito com as almofadas de madeira e cloropreno, notourse que, quando da aplicação de carga, a almofada do compósito permanece com sua forma praticamente inalterada (reta) em sua extremidade enquanto a carga é aplicada e ela vai afundando (deformação). Já o cloropreno toma uma forma parabólica em suas extremidades e vai se deformando mais para cargas bem menores que as cargas do compósito.

Já a madeira mole (Pinus) fica com a extremidade praticamente reta e com cargas mais altas que o cloropreno, porém menores que as cargas suportadas pelo compósito. Além disso, as almofadas desta madeira assumem forma curva em suas bordas inferior e superior, ao passo que o compósito permite o afundamento, sendo assim, adequado para ser utilizado como elemento de apoio.

Ao se avaliar a correlação entre a resistência à compressão e a resistência à tração 
por compressão diametral $\left(\mathrm{f}_{\mathrm{c}} / \mathrm{f}_{\mathrm{t}}\right)$ dos 20 traços do compósito estudado, notou-se que, em geral, o valor da razão entre essas grandezas variava entre 6e 9. Além disso, o valor da relação $\mathrm{f}_{\mathrm{c}} / \mathrm{f}_{\mathrm{t}}$ diminuía à medida que se acrescentava vermiculita à mistura.

Com relação à correlação entre o módulo de elasticidade e a resistência à compressão $\left[\mathrm{E} /\left(\mathrm{f}_{\mathrm{c}}\right)^{1 / 2}\right]$ para o compósito, notou-se que seu valor médio se apresentava no intervalo entre 2100 e $\mathbf{2 7 0 0}$ para a maior parte dos traços moldados com vermiculita, látex e fibras, ao passo que a mesma relação para o concreto vale $\mathbf{4 7 6 0}$. Concluiu-se, também, que a razão entre as correlações concreto/compósito varia entre 2 e 2,5. Como se espera que as almofadas possuam baixo módulo de elasticidade ao mesmo tempo que tenham resistência tão alta quanto possível, conclui-se que os melhores valores para a relação estudada são os das misturas que apresentarem o menor valor possível para a relação $\left[\mathbf{E} /\left(\mathbf{f}_{\mathbf{c}}\right)^{\mathbf{1} / \mathbf{2}}\right]$. Sendo assim, admite-se que o traço procurado deve possuir quantidade de vermiculita variando entre $5 \%$ e $25 \%$. Acredita-se, ainda, que um ponto ótimo deva ser algo mais próximo de $10 \%$ a $15 \%$ de vermiculita.

Notou-se que o valor do módulo de elasticidade era da ordem de 23 a 28 vezes o valor da rigidez da placa quando se utilizava almofada de $10 \mathrm{~cm} \times 10 \mathrm{~cm}$, tanto para almofadas de $10 \mathrm{~mm}$ como para de $20 \mathrm{~mm}$ de espessura. No caso de se utilizar almofada de maior área $(15 \mathrm{~cm} \times 15 \mathrm{~cm})$, o valor da razão $E / R$ tinha maior variação com a espessura, sendo que para almofadas de $5 \mathrm{~mm}$ de espessura o módulo de elasticidade tinha seu valor da ordem de 50 a 60 vezes o valor da rigidez, 30 a 35 vezes para almofadas de $10 \mathrm{~mm}$ e 20 vezes para almofadas de $20 \mathrm{~mm}$.

Com relação à correlação entre a rigidez e a resistência à compressão, notou-se, de forma geral, que a rigidez assumia um valor de 15 a 20 vezes o valor da resistência à compressão quando se utilizavam almofadas de $10 \mathrm{~cm} \times 10 \mathrm{~cm}$. Todavia, quando se utilizavam almofadas maiores $(15 \mathrm{~cm} \times 15 \mathrm{~cm})$ o valor da razão $R / \mathrm{f}_{\mathrm{c}}$ variava mais com a espessura, sendo de, aproximadamente, 7 vezes para espessura 5mm, 12 vezes para espessura $10 \mathrm{~mm}$ e $\mathbf{2 0}$ vezes para espessura $20 \mathrm{~mm}$. Como se espera que as almofadas possuam baixo valor de rigidez ao mesmo tempo que tenham resistência tão alta quanto possível, conclui-se que os melhores valores para a relação estudada são os das misturas que apresentarem o menor valor possível para a relação $\mathbf{R} /\left(\mathbf{f}_{\mathbf{c}}\right)$. Sendo assim, admite-se que o traço procurado deve possuir quantidade de vermiculita variando entre $5 \%$ e $15 \%$.

Com relação às ligações de blocos, notou-se que, à medida que se inclinava uma 
das seções dos corpos-de-prova, perdia-se em resistência em razão da concentração das cargas, haja vista a aplicação de carga excêntrica que ocorre nestes casos.

No entanto, cabe destacar que estes ensaios com aplicação de carga excêntrica (todas as séries que apresentam inclinação nas ligações: séries 2, 3 e 5) não apresentaram resultados muito consistentes e conclui-se que o ensaio deveria ser realizado de outra forma para se avaliar de maneira mais completa o comportamento do compósito com relação a cargas excêntricas. Com relação à forma como foi realizado, conclui-se apenas que a introdução de almofadas do compósito nas ligações atribui maior resistência ao conjunto com ligações inclinadas. No caso deste trabalho, torna-se mais conveniente avaliar os resultados das séries em que as ligações não possuem inclinação.

No caso de se utilizar ligações sem inclinação verificourse que os valores das tensões ficavam muito próximos da tensão máxima obtida ao se utilizar corpos sem emenda. Sendo assim, ao se comparar as séries 1 e 4 notou-se que, para ambas, o traço que atribuía maior resistência ao conjunto era o V5L30F3.

Comparando os valores das resistências, notou-se que os resultados eram bastante próximos; entretanto, ao comparar esses resultados aos dos corpos com emenda e sem almofada, notou-se que havia um maior acréscimo de resistência no conjunto ao se utilizar almofada de espessura 20mm e traço V5L30F3, sendo que para as demais séries esse traço também se apresentou como o mais apropriado.

Obteve-se um custo para a almofada do compósito da ordem de $7 \%$ a $8 \%$ do custo da almofada de neoprene. Para uma obra com custo total de $\mathrm{R} \$ 200.000,00$, utilizando elementos pré-fabricados e almofada de neoprene, o custo total das almofadas de neoprene a serem utilizadas seria de aproximadamente $\mathrm{R} \$ 4.000,00$, ao passo que se fossem utilizadas almofadas do compósito nas ligações seria gasto algo em torno de $\mathrm{R} \$ 300,00$, o que corresponderia a um custo praticamente insignificante no montante da obra, demonstrando ser a almofada do compósito uma boa opção com relação ao custo.

Embora nesta pesquisa tenha-se conseguido avaliar o comportamento do compósito com relação à resistência, elasticidade, rigidez e afundamento, sabe-se que os resultados ainda são modestos para viabilizar a utilização do material como elemento de apoio em ligações entre elementos pré-moldados. Para tanto, futuramente, pretende-se melhorar o nível de estudo do compósito, a partir de observação de seu comportamento 
sob ações repetidas e de longa duração tendo em vista a sua estrutura interna.

Os resultados de afundamento necessitam ser analisados sob o ponto de vista microestrutural, com a utilização de microscópios, para que se possa verificar a influência das imperfeições na superfície das almofadas e, enfim, a capacidade real de acomodar as imperfeições por parte das almofadas.

Também se devem realizar novos ensaios de ligações com almofadas entre corpos-de-prova de concreto, de forma que se possa avaliar de maneira mais adequada a influência da presença da almofada em ligações excêntricas, simbolizando, por exemplo o giro de uma viga sobre um pilar. Realizados estes ensaios de ligações mais adequados, propõe-se, na seqüência, ensaios utilizando o material com os traços apropriados em ligações entre elementos reais de concreto, tais como vigas e apoios em tamanho real. 


\section{REFERÊNCIAS BIBLIOGRÁFICAS}

AFRIDI, M.U.K.; OHAMA, Y.; ZAFAR, I.; DEMURA, K. (1989). Behavior of $\mathrm{Ca}(\mathrm{OH})_{2}$ in polymer modified mortars. The international journal composites and lightweight concrete. Vol. 11, n. 4, 1989.

ASSOCIAÇÃO BRASILEIRA DE NORMAS TÉCNICAS. Ensaio de cimento Portland: método de ensaio, NBR 7215/1982, Rio de Janeiro.

ASSOCIAÇÃO BRASILEIRA DE NORMAS TÉCNICAS. Argamassas e concretos determinação da resistência à tração na compressão diametral de corpos-de-prova cilíndricos: método de ensaio, NBR 7222/1983, Rio de Janeiro.

ASSOCIAÇÃO BRASILEIRA DE NORMAS TÉCNICAS, Ensaio de compressão de corpos-de-prova cilíndricos de concreto: método de ensaio, NBR 5739/1980, Rio de Janeiro.

ASSOCIAÇÃO BRASILEIRA DE NORMAS TÉCNICAS, Projeto de estruturas de concreto, projeto de revisão da NBR 6118/2001.

ASSOCIAÇÃO BRASILEIRA DE NORMAS TÉCNICAS - Revisão da NB 1, Projeto e execução de obras de concreto armado. Rio de Janeiro, 1999.

BALAGURU, P.N.; SHAH, S.P. (1992). Fiber-reinforced cement composites. New York: McGraw-Hill.

BENTUR, A.; MINDESS, S.; DIAMOND, S. (1985c). Pull out process in steel fiber reinforced cement. The International Journal of Cement Composites and Lightweight Concrete. V.7, n. 1, p. 29-37, Feb. 1985c. 
BIJEN, J. (1993). Improved mechanical properties of glass fiber reinforced cement by polymer modification. Anais do simpósio internacional sobre materiais reforçados com fibras para construção civil. EPUSP. São Paulo, 1993.

CARVALHO, R.C.; FIGUEIREDO FILHO, J. R. (2001). Cálculo e Detalhamento de Estruturas Usuais de Concreto Armado. São Carlos, EdUFSCar, 2001.

COMITE EURO-INTERNACIONAL DU BETON. (1991). CEB-FIP model code 1990. Bulletin d'Information, n. 203-205. (MC-CEB/90).

CURRIE, B.; GARDINER, T. (1989). Bond between polypropylene fibers and cement matrix. The International Journal of Cement Composites and Lightweight Concrete. V. 11, n. 1, p. 3-9, Feb. 1989.

EL DEBS, M. K. (2000). Concreto pré-moldado: fundamentos e aplicações. EESCUSP, São Carlos, 2000. 465p.

EL DEBS \& EKANE E. B. (1998). Tension tests of mortar reinforced with steel meshes and polymeric fibers. In Ferrocement 6 - Lambot Symposium. Proceeding of Sixth International Symposium on Ferrocement. A.E. Naaman editor. University of Michigan, Ann Arbor, June, 1998, pp. 403-414.

FERREIRA, M.A. (1999). Deformabilidade de Ligações Viga-pilar de Concreto Prémoldado. São Carlos, Tese Doutorado, EESC-USP.

FIORELLI, J. (2002). Utilização de fibras de carbono e de fibras de vidro para reforço de vigas de madeira. Dissertação de Mestrado. Escola de Engenharia de São Carlos. USP, 2002.

GUIMARÃES, A.E.P. (1999). Análise de pilares de concreto de alta resistência com adição de fibras metálicas submetidos à compressão centrada. Tese de Doutorado. Escola de Engenharia de São Carlos. USP. São Paulo, 1999.

KATTAR, J.E.; ALMEIDA, N.J. (1999). Cimento Portland. Publicação da Holdercim do Brasil. São Paulo, 1999. 
LITHERLAND, K. L.; OAKLEY, D. R.; PROCTOR, B.A. (1981). The use of accelerated ageing procedures to predict the long term strenght of GRC composites, Cement and Concrete Research. Vol. 11, p. 455-466, Pergamon Press Ltda, 1981.

MANO, E.B. (1985). Introdução a polímeros. Ed. Edgard Blücher Ltda. $4^{\mathrm{a}}$ Edição. São Paulo, 1985.

MACETTO, I. R (2001). Estudo de argamassa de vermiculita com látex tendo em vista a sua utilização em ligações entre elementos pré-moldados. Relatório de Iniciação Científica. Escola de Engenharia de São Carlos, USP. Dezembro, 2001.

MEHTA, P.K.; MONTEIRO, P.J.M. (1992). Concrete: structure, properties and materials. 2.ed. Englewood Cliffs: Prentice-Hall.

MEHTA, P. K. \& MONTEIRO, P.J.M (1994). Concreto estrutura, propriedades e materiais. Editora PINI. São Paulo, 1994.

MIOTTO, A. M. (2002). Ligações viga-pilar de estruturas de concreto pré-moldado com ênfase ao estudo da deformabilidade ao momento fletor. 234f. Doutorado (Engenharia de Estruturas) - Escola de Engenharia de São Carlos, Universidade de São Paulo, 2002.

NEVILLE, A. M. (1997). Propriedades do concreto. $2^{a}$ edição. Editora Pini, São Paulo, 1997, cap. 12, 674-691.

OHAMA, Y. (1998). Polymer-based admixtures. Cement and concrete composites. Ed. 20. Elsivier science. 1998.

OLIVEIRA, C.T.A. \& AGOPYAN, V. (2000). Estudo da água do poro de pastas de cimento de escória pelo método da água de equilíbrio. Boletim técnico da Escola Politécnica da USP. São Paulo, 2000.

PERUZZI, A.P. (2002). Comportamento das fibras de vidro convencionais em matriz de cimento Portland modificada com látex e adição de sílica ativa. Dissertação de Mestrado. Escola de Engenharia de São Carlos. USP. 96p. 2002. 
PURNELL, P.; SHORT, N.R.; PAGE, C.L.; MAJUNDAR, A.J. (2000). Microestrutural observations in new matrix glass fiber reinforced cement. Cement and concrete research. Ed. 30, 2000.

ROSSIGNOLO, J. A. (1999). Propriedades da argamassa de cimento Portland modificada com látex estireno-butadieno para revestimento de fachadas. Dissertação de Mestrado. Escola de Engenharia de São Carlos. USP. 107p. São Paulo, 1999.

SAVASTANO JR., H. (1994). Materiais reforçados com fibras: correlação entre a zona de transição fibra-matriz e as propriedades mecânicas. São Paulo: Instituto de Pesquisas Tecnológicas (IPT) - Pini, 1994. - (Publicação IPT 2158 - Boletim 67).

STORTE, M. (1991). Látex estireno-butadieno: aplicação em concretos de cimento e polímero. Dissertação de Mestrado. Escola Politécnica da USP. São Paulo, 1991.

TAKEYA, T. (2001). Análise experimental de estruturas. Escola de Engenharia de São Carlos, USP. Notas de aula.

TEZUKA, Y. (1989). Concreto armado com fibras. São Paulo: ABCP, 24p. (ET 94).

WALTERS, D.G. (1987). What are latex?. Concrete international design \& construction. Vol 9. n. 12. Dez. 1987. 